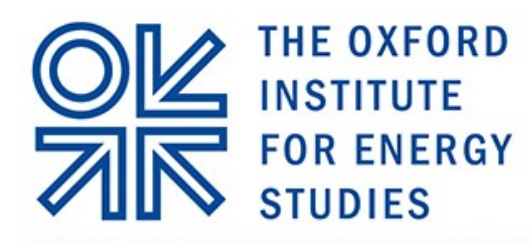

A RECOGNIZED INDEPENDENT CENTRE OF THE UNIVERSITY OF OXFORD

\title{
The Prospects for Natural Gas as a Transport Fuel in Europe
}

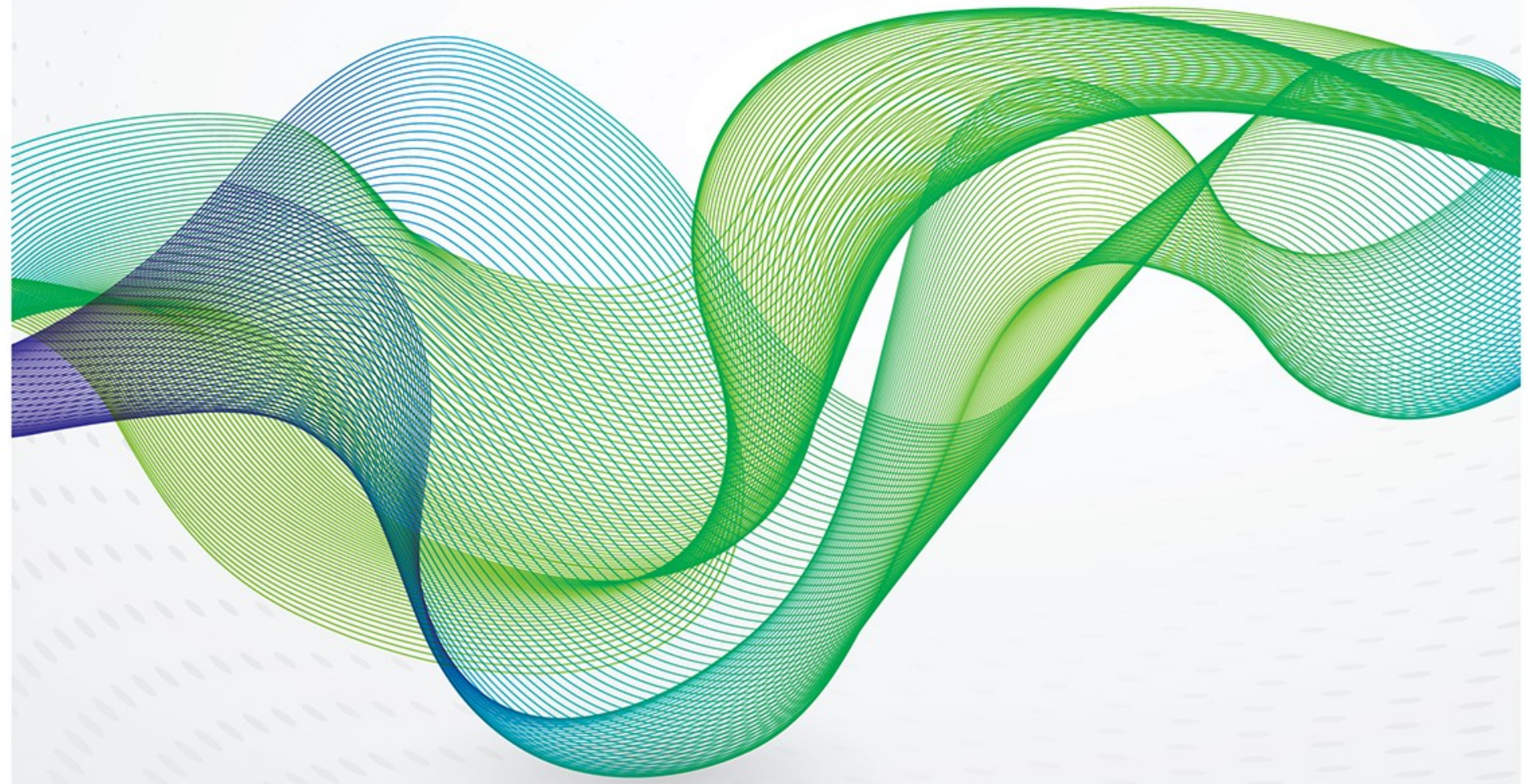

Chris Le Fevre* 
The contents of this paper are the author's sole responsibility. They do not necessarily represent the views of the Oxford Institute for Energy Studies or any of its members.

Copyright $\odot 2014$

Oxford Institute for Energy Studies

(Registered Charity, No. 286084)

This publication may be reproduced in part for educational or non-profit purposes without special permission from the copyright holder, provided acknowledgment of the source is made. No use of this publication may be made for resale or for any other commercial purpose whatsoever without prior permission in writing from the Oxford Institute for Energy Studies.

ISBN 978-1-907555-96-1 


\section{Acknowledgements}

I would like to record my thanks for the help I have been given by many organisations and individuals in writing this paper. I received much valuable input from a number of sponsors of the Natural Gas Programme who have an interest in this area. These include Centrica, Gasunie, National Grid, Shell, Statoil and the Swedish Energy Agency. I have also benefited from the expertise of a number of individuals with direct experience of operating in the NGV sphere and particular thanks are due to Nick Power of BOC, John Baldwin of CNG Services, Nick White of MJM Energy, Gennady Ryabtsev at Psikhea, Ukraine and Juan Angel Terron Alonso of the Municipality of Madrid. Finally I am also most grateful to colleagues at the Oxford Institute of Energy Studies who have helped in understanding a number of the more intricate aspects of the natural gas/transport interface - these include David Ledesma, Patrick Heather, Simon Pirani, leda Gomes, Bassam Fattou and of course Howard Rogers for his valuable advice and encouragement. I would also like to thank John Elkins for his diligence and skill in editing the final document though any remaining errors are fully my own. 


\section{Preface}

In the wake of the recession resulting from the financial crisis of 2008, European demand for natural gas is essentially stagnant and has recently lost market share to coal and renewables in the power generation sector in various European national markets. This factor, as well as the significant price differential between natural gas and oil products since 2008 , has created renewed interest in the market for natural gas in transport.

Gas in transport is neither new nor revolutionary. An assessment of gas' prospects in this sector relates to its ability to displace other fuels (existing and new alternatives). An additional complication is the need to consider transportation sub-sectors, namely: light duty road transport, public passenger road transport, freight and goods vehicles and marine and inland waterway shipping.

In this comprehensive paper Chris Le Fevre draws on extensive research and discussion with interested bodies to address the case for natural gas in transport, the extent and likelihood of its adoption, the long term implications for additional European gas demand and the key policy drivers and structural challenges which would encourage or inhibit these developments.

In addition to our research on national and regional demand and supply developments, gas price formation evolution and the geo-political and regulatory dimensions of natural gas, we are also committed to addressing supply and demand side developments outside of the 'business as usual' category. I am grateful to Chris for this outstanding paper which fully addresses the rather open-ended aspirations for gas in transport made on many a conference platform.

Howard Rogers

Oxford, March 2014 

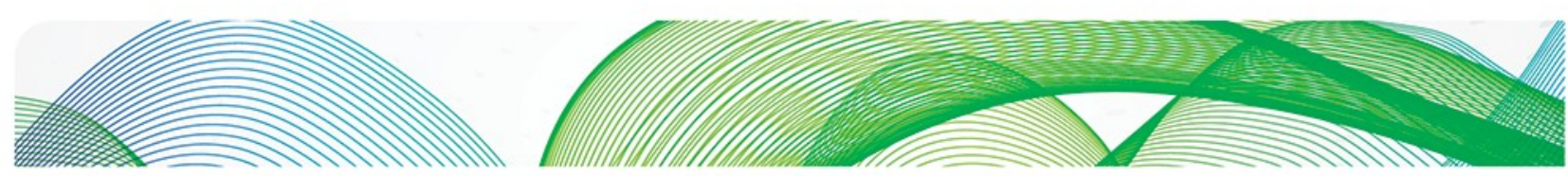
䢰

\section{Contents}

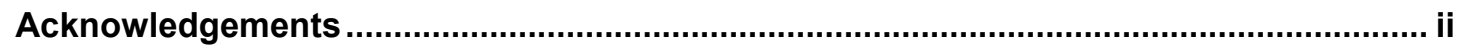

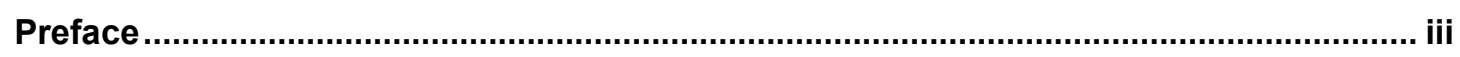

1. Introduction - The role of natural gas in transportation ............................................ 1

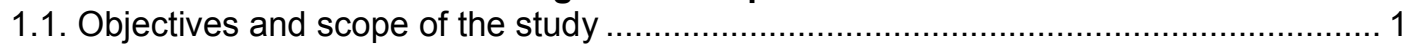

2. The demand for energy in transportation in Europe ................................................. 3

2.1. Energy in transport - the present situation ........................................................ 3

2.2. How demand for transport in Europe might evolve ................................................ 7

2.3. Summary of the role of energy in European transport ............................................. 10

3. An overview of the factors influencing the use of natural gas in transport................11

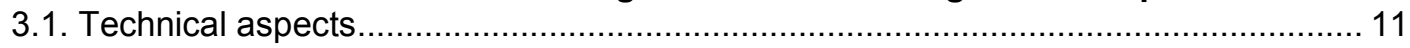

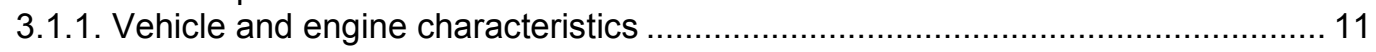

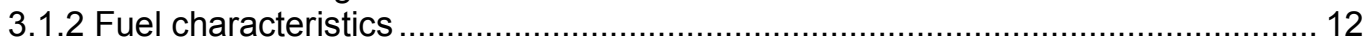

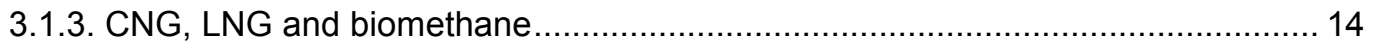

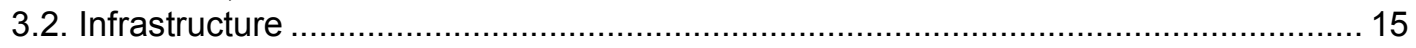

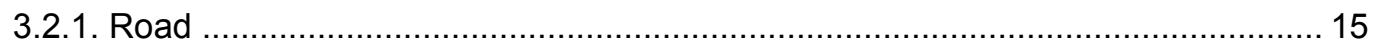

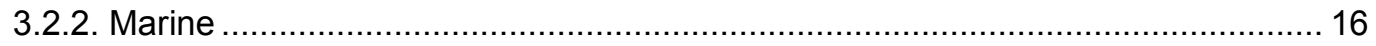

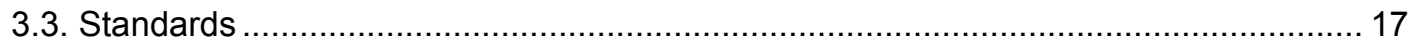

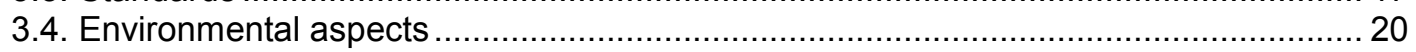

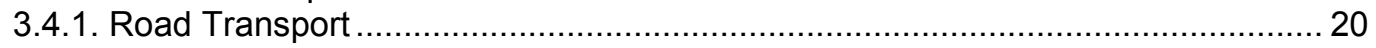

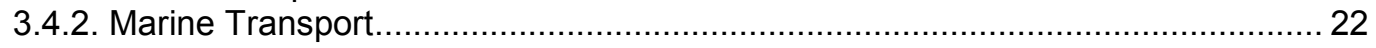

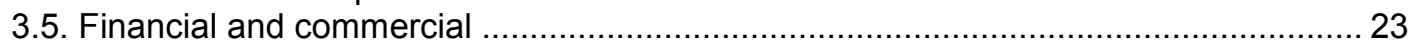

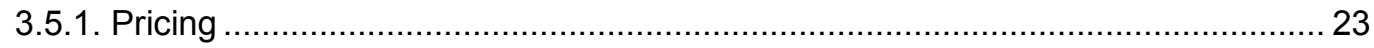

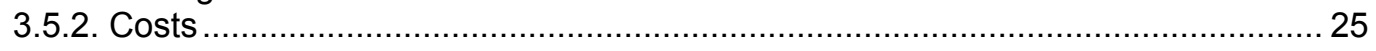

3.6. Summary of the factors influencing the use of natural gas in transport ...................... 26

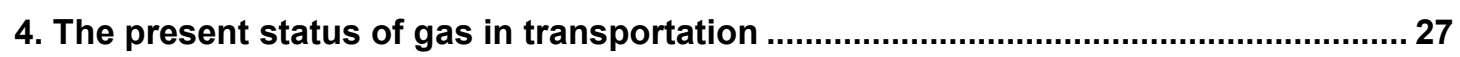

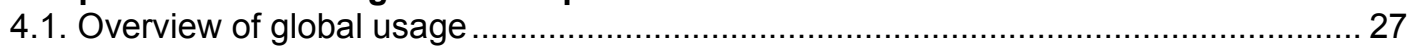

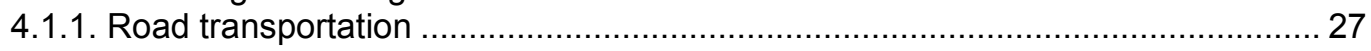

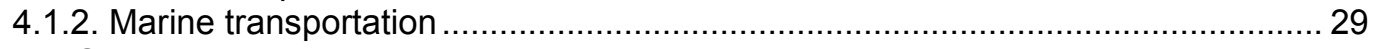

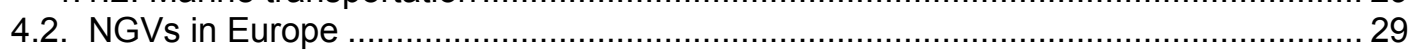

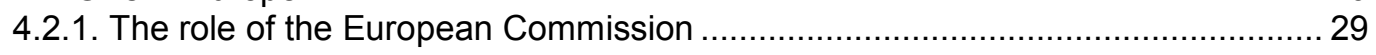

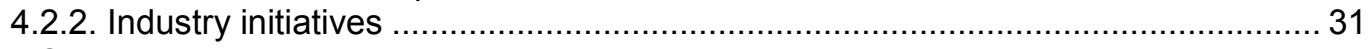

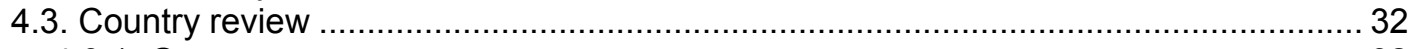

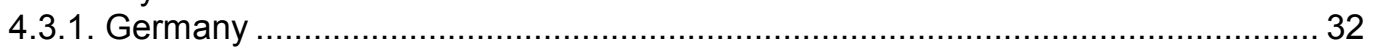

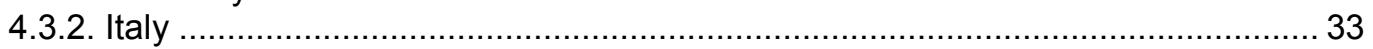

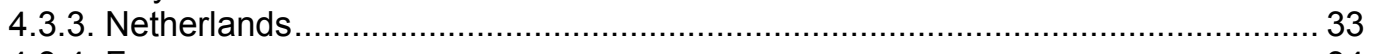

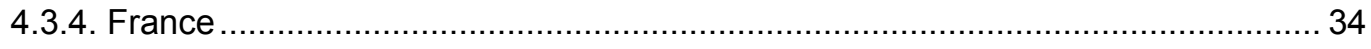

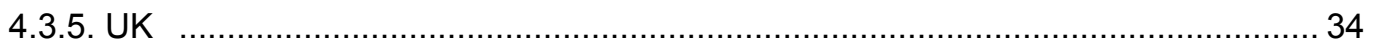

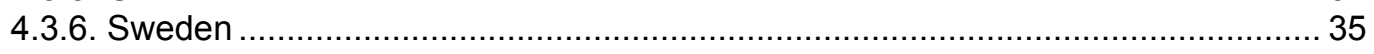

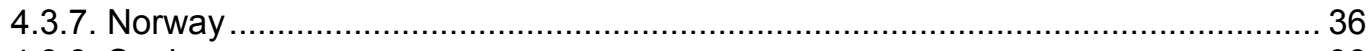

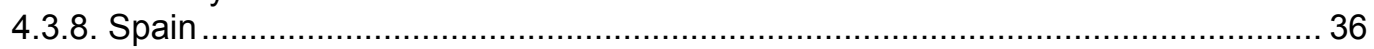

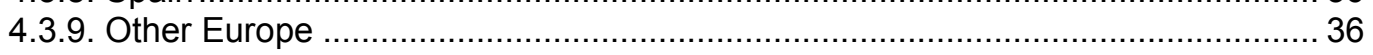

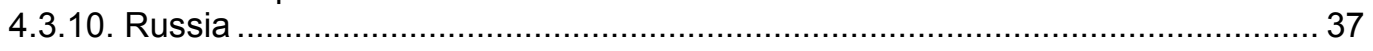

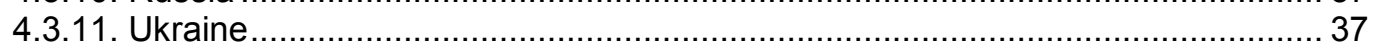

4.4.Summary of the present status of NG in transportation in Europe ............................. 38

5. Outlook for future usage of natural gas in transport..................................................39

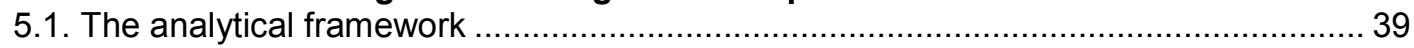

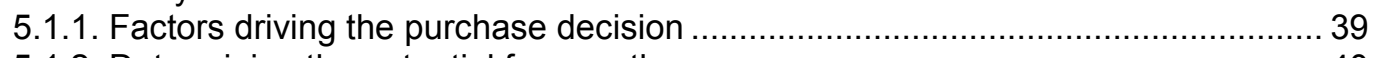

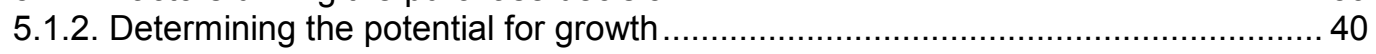



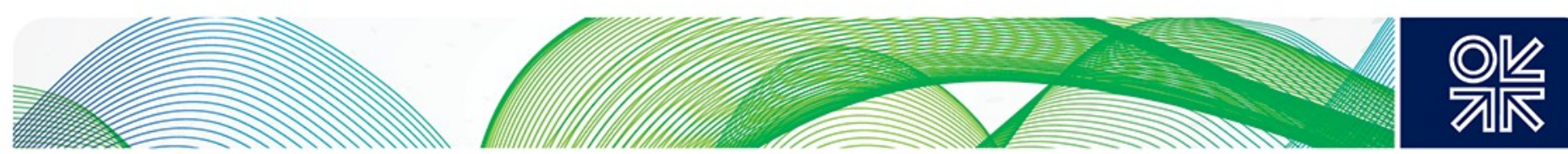

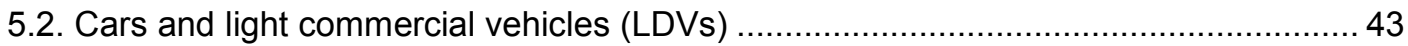

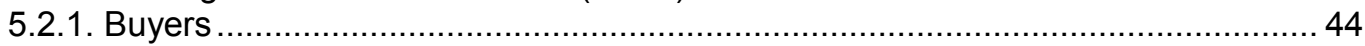

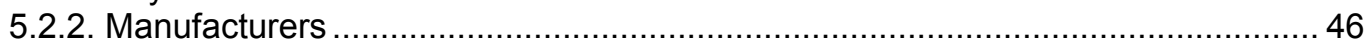

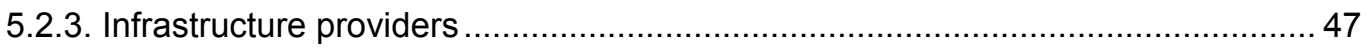

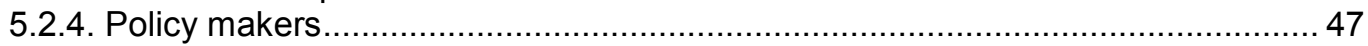

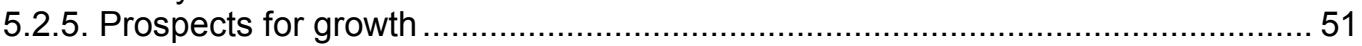

5.2.6. Cars and light commercial vehicles - conclusions .............................................. 52

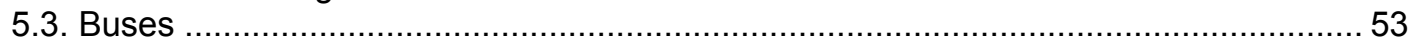

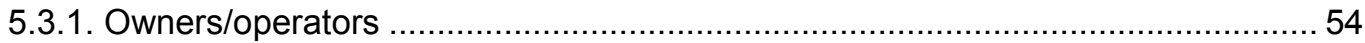

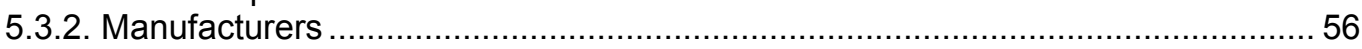

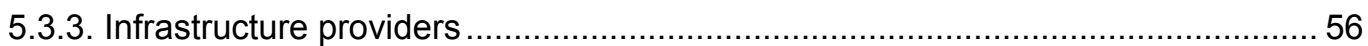

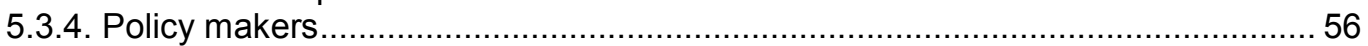

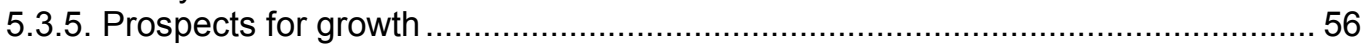

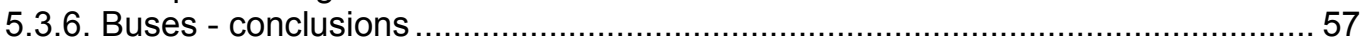

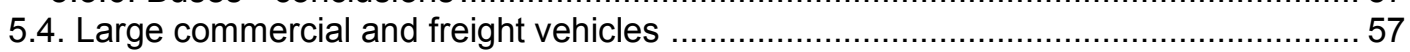

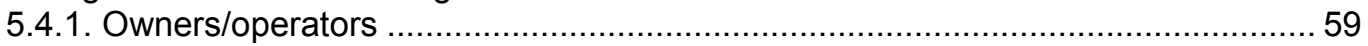

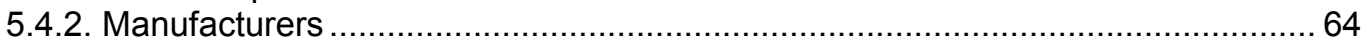

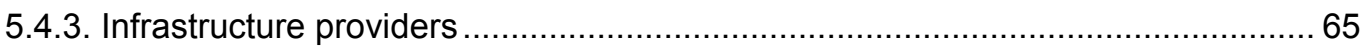

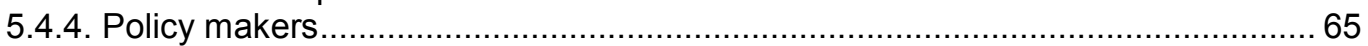

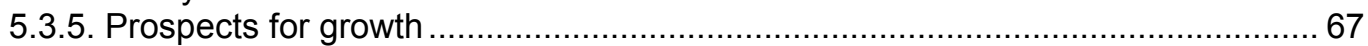

5.4.5. Large commercial and freight vehicles - conclusions ..................................... 68

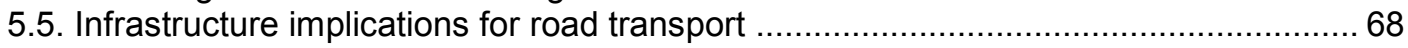

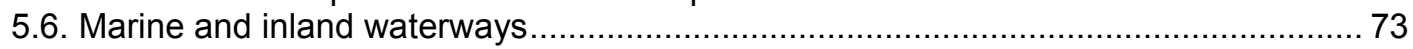

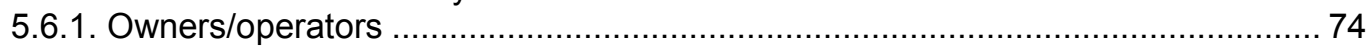

5.6.2. Ship builders and engine manufacturers .................................................. 76

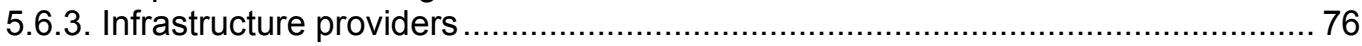

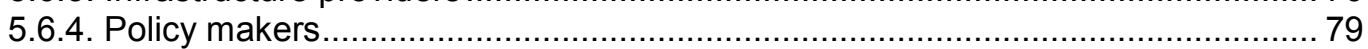

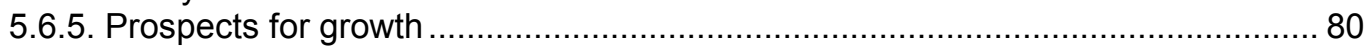

5.7. Summary of projections and comparison with alternative forecasts ......................... 80

5.8. Summary of the outlook for future usage of natural gas in transport......................... 84

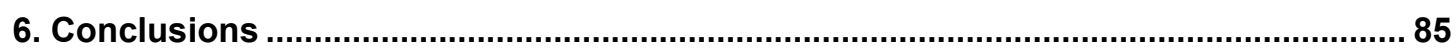

6.1. The overall prospects for natural gas usage in transport in Europe .......................... 85

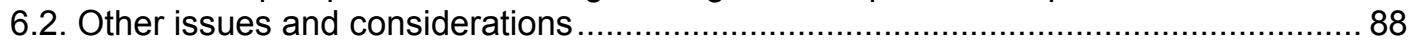

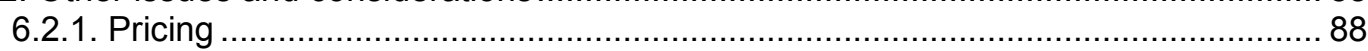

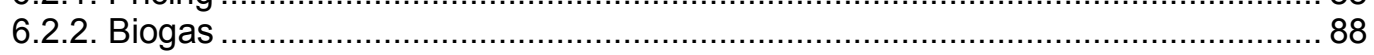

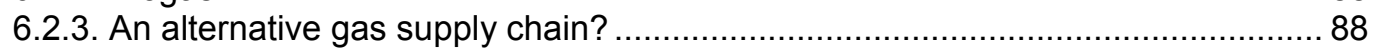

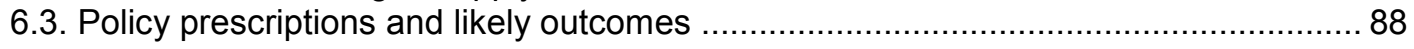

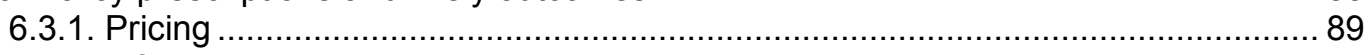

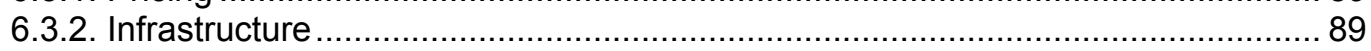

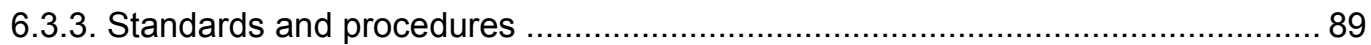

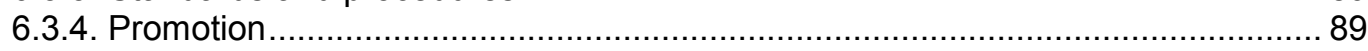

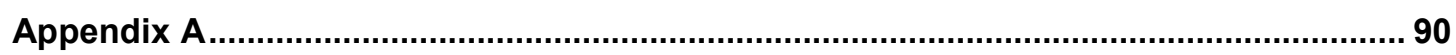

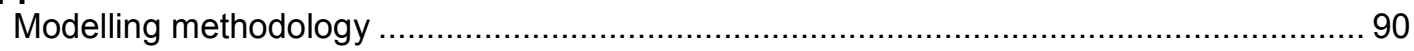

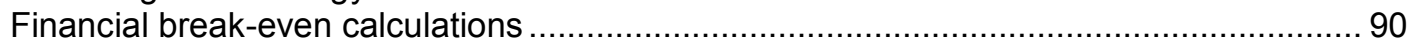

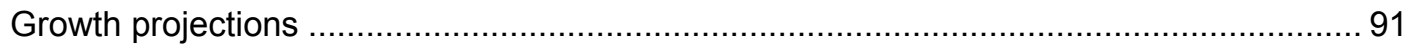

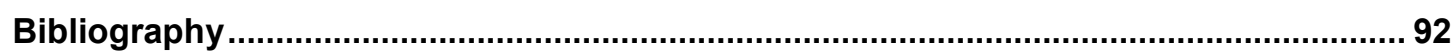

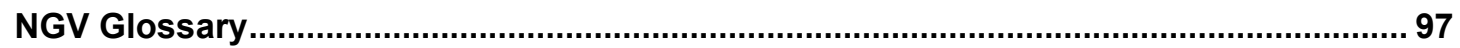



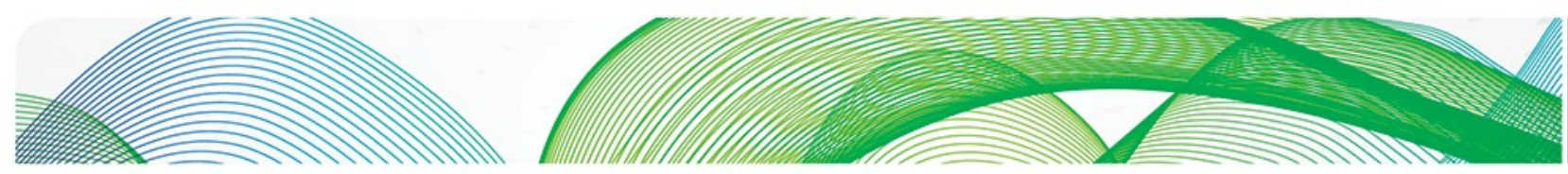
OKK

\section{Figures}

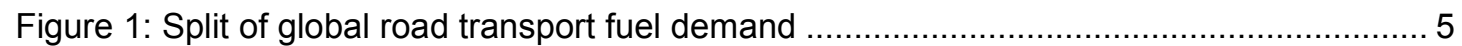

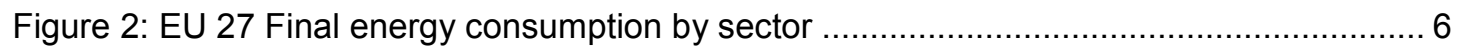

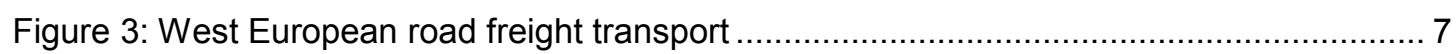

Figure 4: Road Fuel demand in 12 top EU consuming countries....................................... 8

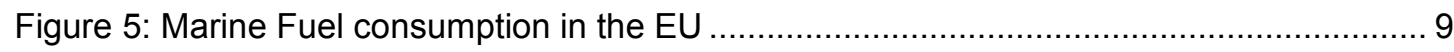

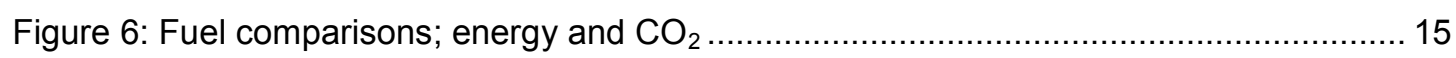

Figure 7: Alternative marine LNG bunkering solutions .................................................. 17

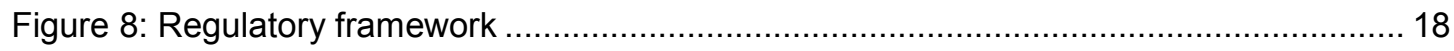

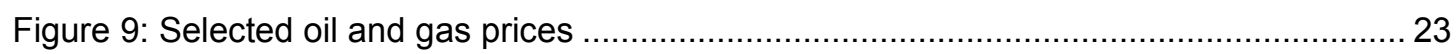

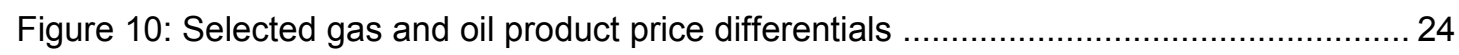

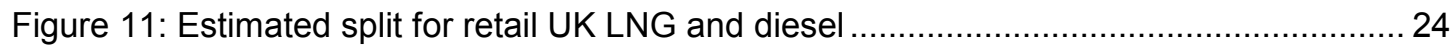

Figure 12: Leading NGV countries (\% of population of NG vehicles in the top 10 countries). 27

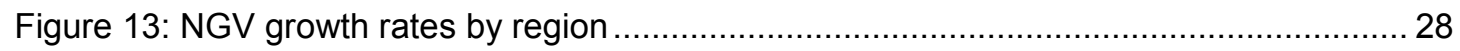

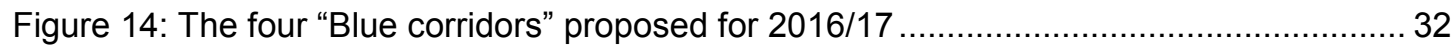

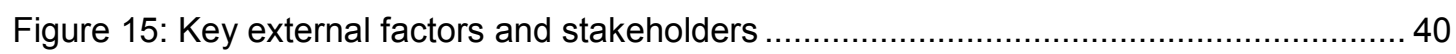

Figure 16: Example $S$ curve showing predicted penetration profile for aerodynamic improving

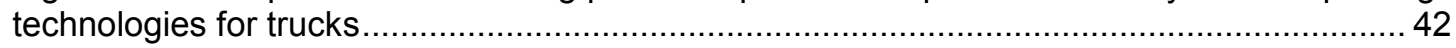

Figure 17: Key external factors and stakeholder map for cars and light vans ...................... 44

Figure 18: Factors initiating the decision to buy current car .............................................. 45

Figure 19: NGV growth in Italy and Germany 2007 - 2013 (Number of LDVs) ...................... 51

Figure 20: Key external factors and stakeholder map for buses ......................................... 54

Figure 21: Key external factors and stakeholder map for large commercial vehicles ............. 58

Figure 22: Break-even calculations for new LNG truck - 100\% Natural Gas ......................... 61

Figure 23: Break-even calculations for new LNG truck - 75\% Natural Gas ........................... 61

Figure 24: 3 year break-even v estimated current discount of gas to diesel.......................... 63

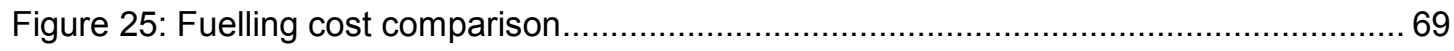

Figure 26: Existing and planned LNG import terminals in Europe ........................................ 72

Figure 27: Key external factors and stakeholder map for marine and inland waterway vessels 73

Figure 28: Existing and planned LNG bunkering facilities in Europe .................................. 77

Figure 29: Marine LNG refuelling costs $v$ throughput .................................................... 78

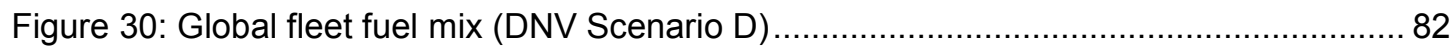




\section{Tables}

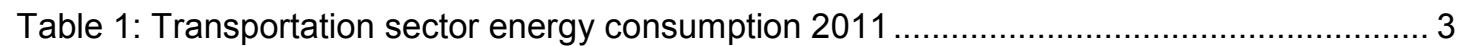

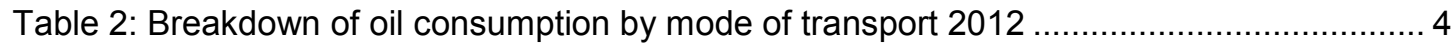

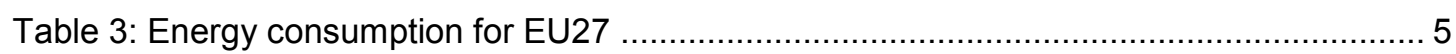

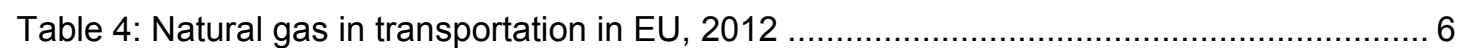

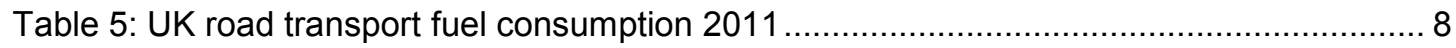

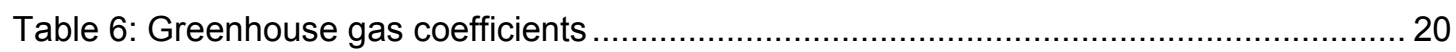

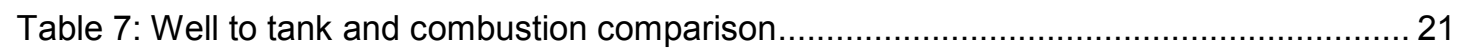

Table 8: Comparison of vehicle fuel tax rates for selected European countries ..................... 25

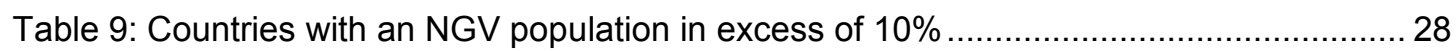

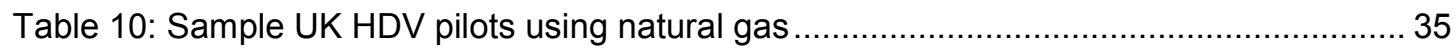

Table 11: Current theoretical annual methane consumption by vehicles in the EU and EFTA

Table 12: Natural gas light duty vehicles and CNG refuelling stations in Europe, 2011-12 .. 43

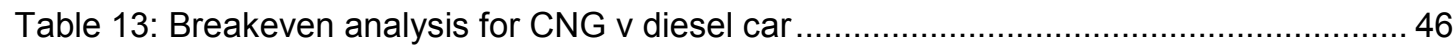

Table 14: CNG and diesel comparison between selected cars .............................................. 46

Table 15: Simulated energy and environmental TTW performance for cars ..........................48

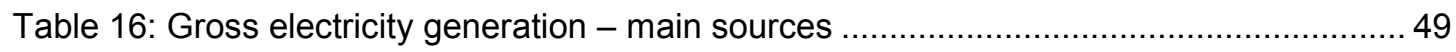

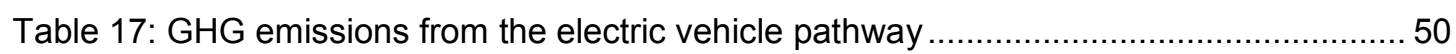

Table 18: Well to Wheel comparison for selected fuel pathways ........................................ 50

Table 19: Projected market share in car and LCV market for Europe ................................. 52

Table 20: Sales of non-diesel or petrol passenger cars in selected countries ( $\%$ of total) ..... 52

Table 21: Natural gas buses in Europe, 2012 …........................................................ 53

Table 22: Performance and economics of gas buses compared to diesel............................ 55

Table 23: Projected market share in bus market for Europe (Excluding Russia and Ukraine) 57

Table 24: Natural gas medium and large commercial vehicles and LNG refuelling stations in

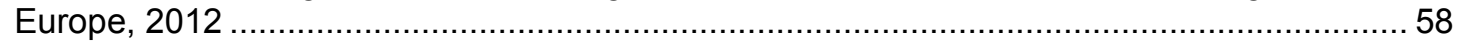

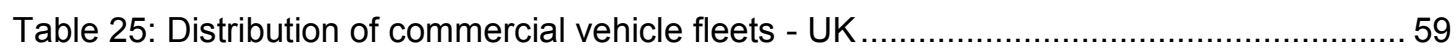

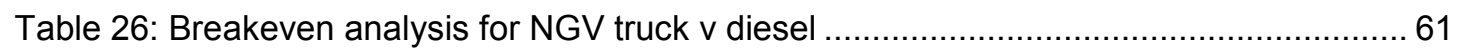

Table 27: Required discount for NGV truck $v$ diesel to achieve breakeven within 3 years ..... 62

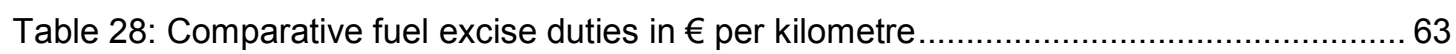

Table 29: Comparison of CNG v LNG for truck operators.................................................. 64

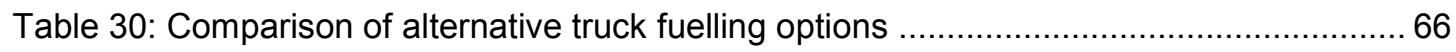

Table 31: Actual environmental performance of gas $v$ diesel trucks........................................ 66 

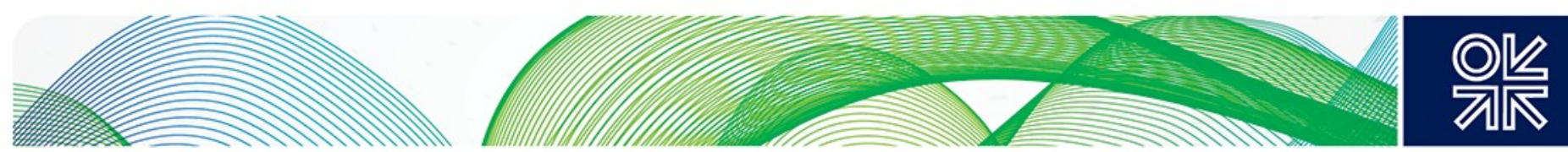

Table 32: Projected market share in the large truck market for Europe (excluding Russia and Ukraine)

Table 33: Projected market share in the medium commercial vehicle market for Europe (excluding Russia and Ukraine).

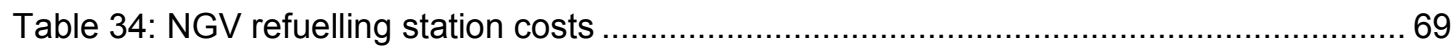

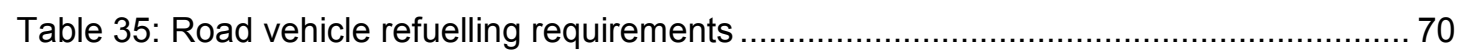

Table 36: Existing and planned LNG L-CNG vehicle refuelling stations ............................. 71

Table 37: Comparison of alternative marine fuelling options for 9,000 DWT vessel .............. 74

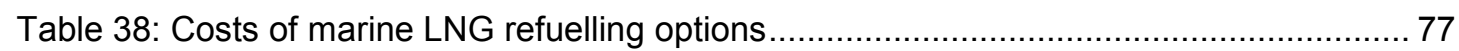

Table 39: Projected gas consumption in marine and IWT sector ....................................... 80

Table 40: Global demand for gas in road transportation - external forecasts ......................... 81

Table 41: International marine gas demand external forecasts $(\mathrm{bcm})$.................................. 82

Table 42: European demand for gas in transportation - external forecasts ........................... 83

Table 43: European Demand for gas in transportation - summary of study projections (bcm)

Table 44: Summary of "first order" issues for natural gas in transportation 

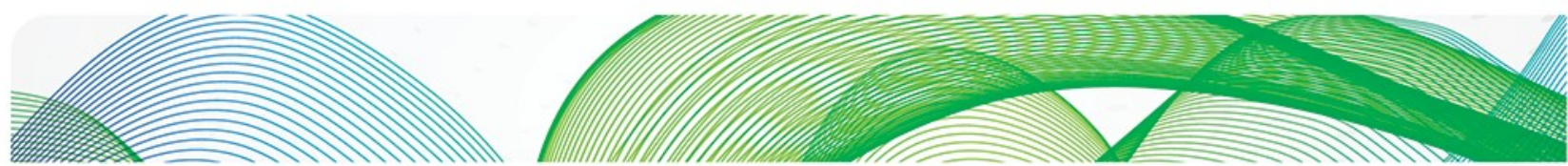

\section{Introduction - The role of natural gas in transportation}

The use of natural gas in transportation is well established globally with over 17 million natural gas vehicle (NGVs ${ }^{1}$ ) worldwide. There are some 24,000 refuelling stations ${ }^{2}$ and demand in 2013 accounted for around $2 \%$ of total energy use in road transport ${ }^{3}$.

Continuing high oil prices and the environmental advantages of gas over oil have led to increased interest in natural gas as a transportation fuel. There is also increasing interest in LNG as a fuel for heavy goods vehicles and shipping.

The IEA expects the growth in NGVs to continue though barriers such as lack of refuelling infrastructure and inadequate policy actions will inhibit the rate.

Levels of global car ownership are forecast to continue to grow strongly as is the demand for road freight. Significant penetration of the transport sector by natural gas could therefore represent an attractive growth opportunity for the fuel.

\subsection{Objectives and scope of the study}

This study looks at the prospects for NGVs - both road and marine - in Europe. Despite the potentially promising outlook for NGVs they are concentrated in a relatively small number of countries. Furthermore with the exception of Italy and Ukraine, Europe currently has a relatively small share (just over $10 \%{ }^{4}$ ) of the global NGV population.

To understand how the position of NGVs in Europe might evolve the study will focus on the following key outcomes:

- To identify the technical, commercial and environmental case for natural gas transportation (NGT) in Europe versus other fuel options

- To assess the extent and likelihood of the adoption of natural gas as a transportation fuel in the European market

- To project the long term impact on European gas demand of alternative growth scenarios reflecting increased NGT usage

- To assess the key policy drivers and structural aspects that could encourage or inhibit the development of the NGT sector in Europe

The study is particularly focussed on Europe and the major gas consuming countries within the EU27. Developments in European countries with relatively smaller populations are also noted where they are of particular relevance to growth in the sector - for example Norway and Sweden with regard to shipping. Russia and Ukraine are also included where appropriate in view of these two countries' importance as gas consumers and the relatively high share of NGVs in Ukraine.

\footnotetext{
${ }^{1}$ The term NGV is used to refer to all modes of transportation including marine vessels unless specifically stated otherwise 

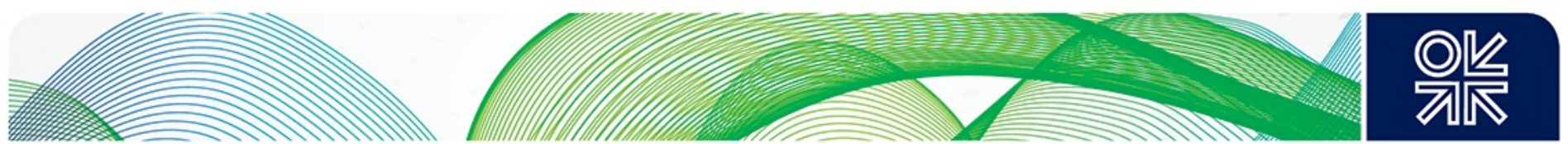

Natural gas as a fuel is not a new mode of transport. It is rather an alternative to existing fuels in existing transport modes. In other words if natural gas is to grow in the transportation sector it has to be market led and adapt to the needs of each segment of the market.

Natural gas has potential in the following transport sectors:

- Light duty road transport - i.e. cars, taxis and small vans

- Public passenger road transport - primarily urban buses

- Freight transport - this sector can be subdivided into medium duty goods vehicles and heavy duty goods vehicles with the latter being split between urban uses such as refuse collection and inter-urban long distance transport

- Marine shipping and inland waterway transport (IWT)

There is also potential in some parts of the world for natural gas in the rail sector. In Europe, which has a high level of railway electrification this is considered less prospective and so has been excluded. The potential for natural gas as a fuel in the aviation sector is also excluded, as it is presently considered to have a very low probability of achieving materiality and is therefore not relevant to this study.

The report is structured as follows:

Chapter 2 provides an overview of the role that energy plays in the transportation sector as a precursor to understanding the potential for natural gas in this market. The main drivers for transport demand and the outlook for the main sectors in Europe are considered.

Chapter 3 contains a detailed assessment of the key factors and influences in each of the main transportation market sectors by providing an overview of the main technical, infrastructural, financial and environmental factors that underpin the case for natural gas vehicles and the alternative fuel and vehicle options.

Chapter 4 provides an overview of the natural gas transportation market globally and in Europe. It considers developments in some European countries in more detail in order to provide examples of the type of activities that are presently underway and also looks at the role of the European Commission in promoting alternative fuels for transport.

Chapter 5 looks in detail at the prospects for future usage of natural gas in transport in Europe. As explained above it is important for natural gas to be able to fit into the various market segments in the transportation sector as it is seeking to be an alternative to existing, successful fuels in a well-established framework. The analysis therefore focuses in detail on each market sector and vehicle type and considers the main internal and external factors that may shape and precipitate a decision to switch to natural gas as a fuel. The chapter then suggests some alternative projections of future purchases of gas-fuelled vehicles and the impact these could have on gas demand.

The conclusions are presented in Chapter 6 , which also includes some recommendations for policy actions and other implications that may arise if the transportation market in Europe becomes a significant consumer of natural gas. 

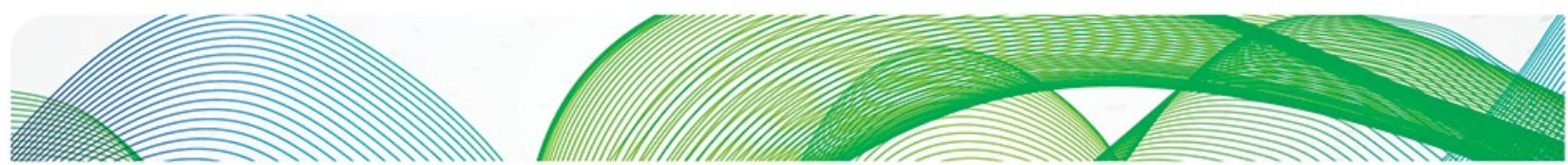

\section{The demand for energy in transportation in Europe}

Transport is a major consumer of energy. This chapter examines the present status of energy in transport and the role played by various fuels - of which oil is still the most important. The respective shares of energy demand in the main transportation sectors (passenger cars, road freight, shipping etc) are considered both globally and in more detail for Europe. Specifically for Europe the recent evolution of transport demand is presented in order to provide some insights into when and how this might impact on energy demand in general and the likely choice of fuel.

\subsection{Energy in transport - the present situation}

IEA statistics indicate that transportation accounted for around $27 \%$ of global total final consumption of energy in 2010. Oil dominates the sector providing some $93 \%$ of transportation consumption whilst nearly $62 \%$ of oil consumption was in the transportation sector. ${ }^{5}$ These figures are broadly mirrored in Europe as shown in Table 1. This table also shows the other main fuels consumed in the sector. Natural gas is not reported separately and consumption figures must therefore be determined from other sources as described below.

Table 1: Transportation sector energy consumption 2011

\begin{tabular}{|l|l|l|l|l|}
\hline $\begin{array}{l}\text { Transportation } \\
\text { consumption (mtoe) }\end{array}$ & World & $\begin{array}{l}\text { OECD } \\
\text { Europe }\end{array}$ & EU27 & Russia \\
\hline Oil & 2264 & 312 & 296 & 59 \\
\hline Electricity & 25 & 6 & 6 & 8 \\
\hline Biofuels & 59 & 14 & 14 & - \\
\hline Other & 96 & 3 & 3 & 31 \\
\hline Total & 2444 & 335 & 318 & 98 \\
\hline
\end{tabular}

Source: IEA (2013c)

For the purposes of this analysis the transportation sector can be sub-divided into the following sectors ${ }^{6}$ :

- Passenger cars and taxis

- Light and medium commercial vehicles (LCVs) - vans and lorries under 16 tonnes (gross laden weight)

- Heavy commercial vehicles (HCVs) also referred to as heavy duty vehicles (HDVs ) lorries in excess of 16 tonnes ${ }^{7}$. This group can be further split between urban uses such as refuse collection and inter-urban long distance transport

${ }^{6}$ Some statistics (including Eurostat) include energy consumed in pipeline transport which accounted for $0.8 \%$ of final energy consumption in Europe in 2011
} 

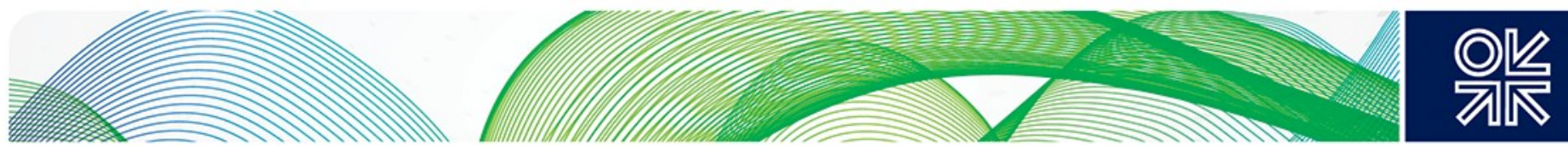

- Public passenger road transport - buses and coaches

- Rail

- Air

- Marine shipping and inland waterways

As described earlier this study excludes the rail and air sectors though they are included in the overall statistics for the purpose of comparison. In global terms oil usage in transport was around 47 million b/d in 2012 of which $35 \mathrm{mb} / \mathrm{d}$ was road transport ${ }^{8}$. The estimated breakdown by transport mode is shown in Table 2. Road transport dominates the sector where the main fuels are gasoline and diesel.

Table 2: Breakdown of oil consumption by mode of transport 2012

\begin{tabular}{|l|c|c|}
\hline Mode & $\begin{array}{l}\text { Estimated consumption } \\
\text { Mb/d }\end{array}$ & Share of total (\%) \\
\hline Passenger cars & 19 & 40.4 \\
\hline Road freight & 14 & 29.8 \\
\hline Marine bunkers and IWT & 5 & 10.6 \\
\hline Aviation & 5 & 10.6 \\
\hline Other & 4 & 8.5 \\
\hline Total & 47 & 100.0 \\
\hline
\end{tabular}

Source: IEA (2013c), Figure 15.7

The IEA estimates there were some 50 million trucks on the roads world-wide in 2013 compared with around 850 million passenger cars and that of the 80 million road vehicles sold in 2011,7 million were trucks ${ }^{9}$. Despite this relatively small proportion, the size and weight of these vehicles mean they account for a large share of fuel consumed in transport for example around $60 \%$ of all diesel sold (approximately $9 \mathrm{mb} / \mathrm{d}$ ) ${ }^{10}$.

In global terms natural gas accounted for around $2 \%$ of road transport fuel in $2012^{11}$ growing from just $0.2 \%$ in 2000 . BP (2014) estimates that total gas demand in the transport sector (road and marine) was $46.6 \mathrm{bcm}$ in 2012. The IEA (2013b) states that this share is projected to grow to $2.5 \%$ by $2018^{12}$ and to $4 \%$ by 2035 . The projected share of gas in the truck market is projected to be $2.3 \%$ by this time ${ }^{13}$ though shares are expected to be higher in certain markets such as the USA. BP (2014) forecasts gas demand to grow to $213 \mathrm{bcm}$ by 2035 , equating to $6.6 \%$ of total forecast transport energy demand and $4 \%$ of total forecast gas demand.

The shares of fuel, including short-term projections, are shown in Figure 1, alternative forecasts of the future share of natural gas are discussed in a later chapter.

\footnotetext{
${ }^{7}$ Definitions of vehicle type vary between countries. This study has assumed HCVs have a gross laden weight above 16 tonnes

${ }^{8}$ IEA (2013c) p 512

${ }^{9}$ IEA (2012) p 93

${ }^{10}$ IEA (2012) p 94

${ }^{11}$ IEA (2013c ) p516

${ }^{12}$ IEA (2013a)

${ }^{13}$ IEA (2012) p95
} 

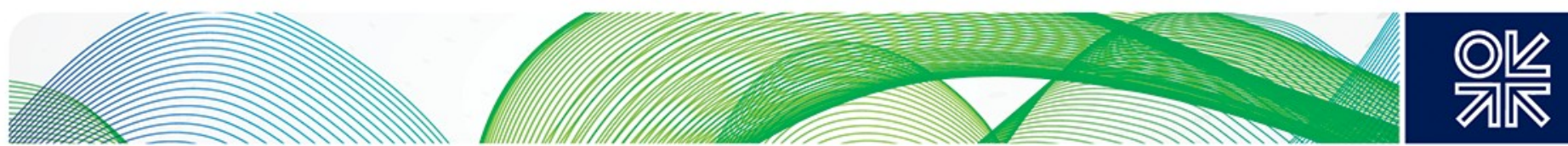

Figure 1: Split of global road transport fuel demand

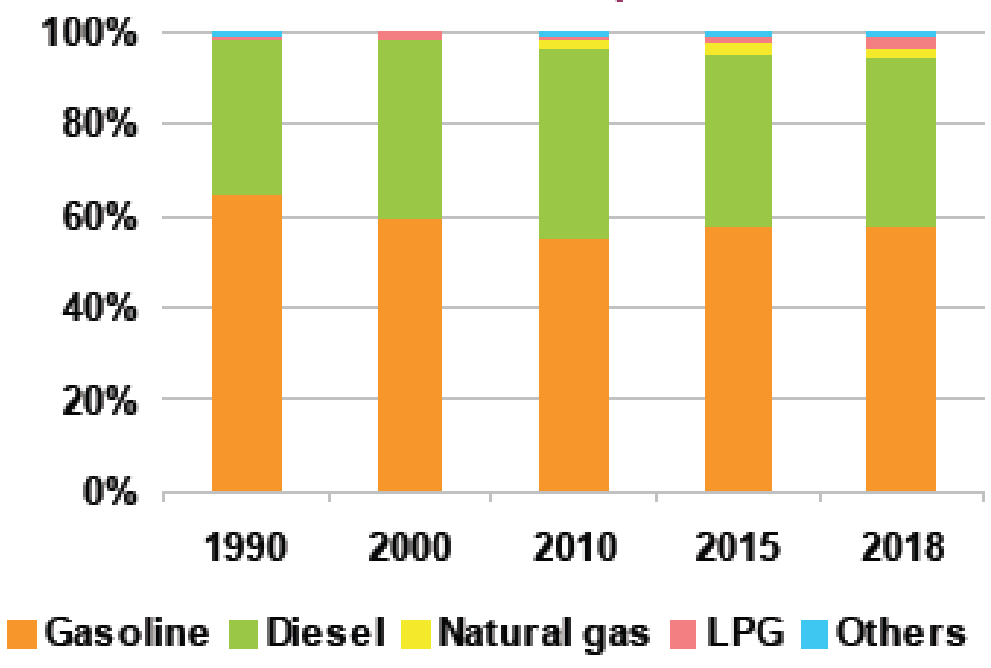

Source: IEA Medium Term Oil Report, 2013 P 26

In the global shipping sector the fuel used in marine bunkers is primarily fuel oil accounting for around $87 \%$ in 2010 with gasoil/diesel supplying most of the remainder ${ }^{14}$. Small amounts of LNG are used as shipping fuel for LNG carriers and some passenger/freight shipping in the Baltic region.

Turning in more detail to Europe Table 3 provides the most recent figures for energy consumption in transport for the EU27.

Table 3: Energy consumption for EU27

\begin{tabular}{|l|l|l|l|l|l|l|l|}
\hline $\begin{array}{l}\text { Final Energy } \\
\text { Consumption } \\
\text { (mtoe) }\end{array}$ & $\begin{array}{l}\text { Total } \\
\text { FEC }\end{array}$ & $\begin{array}{l}\text { All } \\
\text { Transport }\end{array}$ & Road & Rail & Air & $\begin{array}{l}\text { Inland } \\
\text { waterways }\end{array}$ & Pipeline \\
\hline 2010 & 1152.5 & 365.1 & 299.7 & 7.4 & 49.4 & 6.1 & 2.5 \\
\hline 2011 & 1103.3 & 364.1 & 297.6 & 7.3 & 50.5 & 5.9 & 2.8 \\
\hline
\end{tabular}

Source: Eurostat (2013): Table 3.1.4

Overall energy consumption has been relatively static within the EU over the past 20 years as shown in Figure 2. Over the period from 1990 to 2011 total final consumption only increased by an annual rate of $0.12 \%$ whilst energy consumption for transport increased by an annual rate of $1.23 \%$. As a result transport's share of total final consumption increased from $26 \%$ to $33 \%{ }^{15}$.

Within the EU transport accounts for around 25\% of greenhouse gases (GHGs) and road transport alone contributes about $20 \%$ of total $\mathrm{CO}_{2}$ emissions. The EC notes that whilst GHGs in non-transport sectors decreased by $15 \%$ between 1990 and 2007 emissions from transport increased by $36 \%$ over the same period as a result of increased demand outweighing any improvements in vehicle efficiency ${ }^{16}$. 

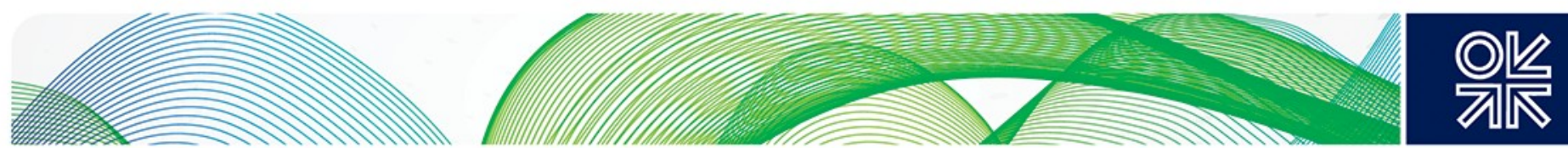

Figure 2: EU 27 Final energy consumption by sector

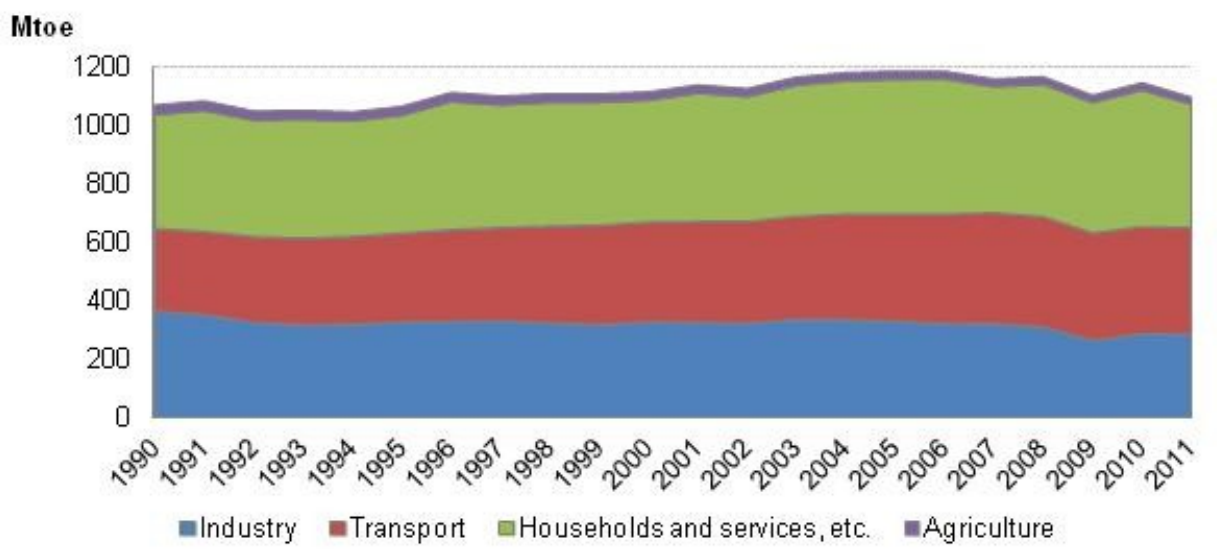

Source: Eurostat (2013), Graph 3.1.5

Energy consumption for transport in Russia has declined in absolute terms over the last ten years though its share of total final energy consumption has increased from $19 \%$ in 1990 to $22 \%$ in $2011^{17}$.

Eurogas (2013b) provides data on natural gas consumption in transport by country. In 2012 transport represented only $0.4 \%$ of natural gas sales in the EU though this was an increase of $6 \%$ on 2011. The countries where gas consumption in transport is significant (i.e. $>0.8$ $\mathrm{TWh} / \mathrm{a}$ ) are shown in Table 4. This demonstrates that with the notable exception of Italy and (possibly) Poland ${ }^{18}$ gas consumption in transport is still a very small proportion of the total.

Table 4: Natural gas in transportation in EU, 2012

\begin{tabular}{|c|c|c|c|}
\hline \multirow{2}{*}{ Country } & \multirow{2}{*}{$\begin{array}{c}\text { Total gas } \\
\text { consumption } \\
\end{array}$} & \multicolumn{2}{|c|}{ Of which transport } \\
\cline { 3 - 4 } & (TWh) & TWh & $\%$ \\
\hline France & 492.4 & 1.3 & $0.3 \%$ \\
\hline Germany & 909.1 & 2.8 & $0.3 \%$ \\
\hline Italy & 792.6 & 9.6 & $1.2 \%$ \\
\hline Poland & 176.9 & 3.3 & $1.9 \%$ \\
\hline Spain & 362.6 & 0.9 & $0.2 \%$ \\
\hline Other & 2327.3 & 1.9 & $0.1 \%$ \\
\hline EU 28 & 5060.9 & 19.8 & $0.4 \%$ \\
\hline
\end{tabular}

Source: Eurogas (2013b)

${ }^{18}$ The figure for Poland is surprising as there are only 3,300 NGVs in the country and NGVA calculates total consumption by road vehicles as around $0.1 \%$ of total gas consumption.
} 

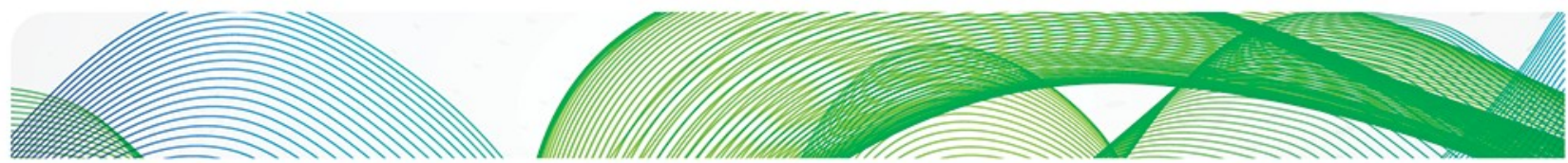

\subsection{How demand for transport in Europe might evolve}

The prime driver for energy demand in transportation is of course the number of vehicle movements. However when demand for transport is measured/reported it is often in terms of passenger miles/kilometre (i.e. number of passengers times the distance travelled) or tonne miles/kilometre (i.e. weight of goods transported times the distance moved) of freight. This means that whilst demand for transport can be growing the amount of energy consumed may be falling if the growth entails a switch in mode from say passenger cars to trains or buses or from small goods vehicles to large freight trains. Figure 3 shows the evolution of road freight transport in Western Europe ${ }^{19}$ over the ten years to 2011. Whilst there has been modest growth overall this masks the impact of the 2008 recession that saw a sharp fall in activity. It should be noted that a significant majority of freight movements was within a country rather than cross border.

\section{Figure 3: West European road freight transport}

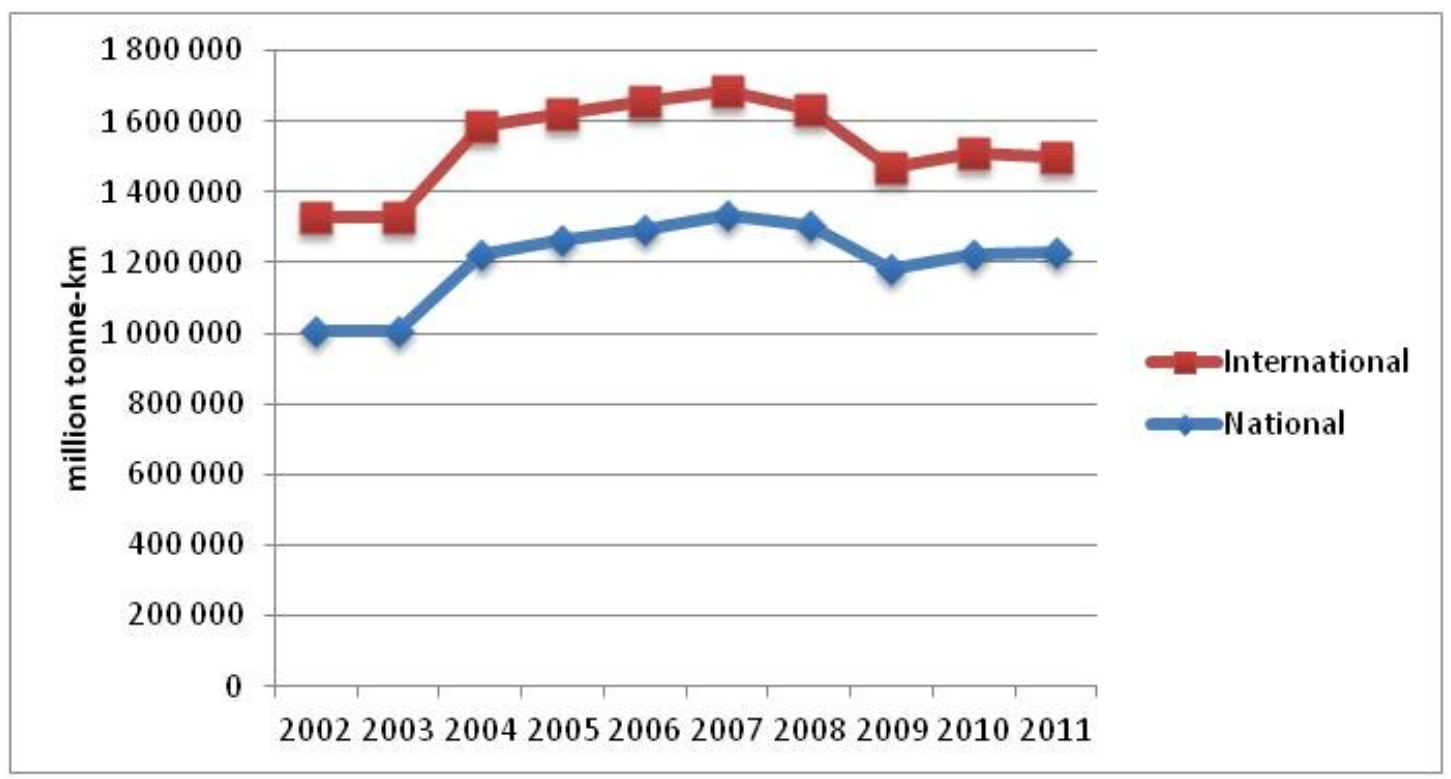

Source: International Transport Forum,

http://www.internationaltransportforum.org/shorttermtrends/Selection.aspx

There is a further dimension to understanding the future level of demand for natural gas in road transport - the split of vehicle type by fuel in each category - which in turn requires an understanding of the evolution of what is referred to as the vehicle parc (i.e. the number of vehicles presently registered and in use) - particularly with regard to passenger cars and road freight vehicles which are expected to remain the key elements in determining future energy demand.

The main global trend projected by the IEA is for modest growth in projected fleet sizes for the EU - unlike the rapid growth that is expected in India, China and Africa ${ }^{20}$ with cars increasing from around 230 million now to just under 300 million by 2035 . Freight activity is

\footnotetext{
${ }^{19}$ The ITF definition includes Switzerland and Norway

${ }^{20}$ IEA (2013c) p513
} 

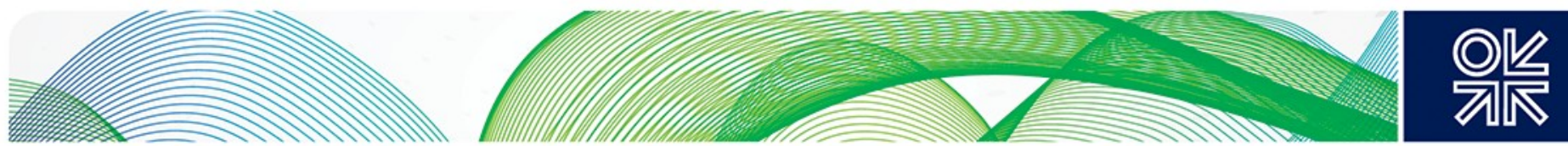

expected to grow broadly in line with economic growth though improvements in fuel efficiency mean that vehicle growth does not translate directly into increased demand for fuel.

Aggregate statistics on fuel usage by different vehicle categories are not readily available for the EU. This is likely to be due to difficulties in data collection (e.g. distinguishing between a commercial vehicle and a car at a filling station) and differences in definition between countries. Figures from some individual countries are available and Table 5 presents data from the UK to give an indication of how fuel usage breaks down across categories. Table 5 indicates that passenger cars account for around $50 \%$ of fuel consumption with HDVs being the next largest category.

Table 5: UK road transport fuel consumption 2011

\begin{tabular}{|l|l|l|l|l|l|l|l|}
\hline & Buses & $\begin{array}{l}\text { Diesel } \\
\text { cars }\end{array}$ & $\begin{array}{l}\text { Petrol } \\
\text { cars }\end{array}$ & $\begin{array}{l}\text { Motor } \\
\text { cycles }\end{array}$ & HDV & LCV & Total \\
\hline $\begin{array}{l}\text { Thousand } \\
\text { tonnes of fuel }\end{array}$ & 1383 & 7663 & 12750 & 167 & 7311 & 4912 & 34186 \\
\hline Percentage \% & 4.0 & 22.4 & 37.3 & 0.5 & 21.4 & 14.4 & 100 \\
\hline
\end{tabular}

Source: DECC - Regional and LA road transport consumption statistics. June 2013. HDV are those vehicles above 16 tonnes

The split between motor gasoline and diesel can vary quite widely however. Figure 4 shows the breakdown for the top 12 consuming countries in the EU. There is a clear trend towards increased dieselisation of passenger cars in the EU growing from just over $12 \%$ in 1992 to around $35 \%$ in $2010^{21}$.

Figure 4: Road Fuel demand in 12 top EU consuming countries

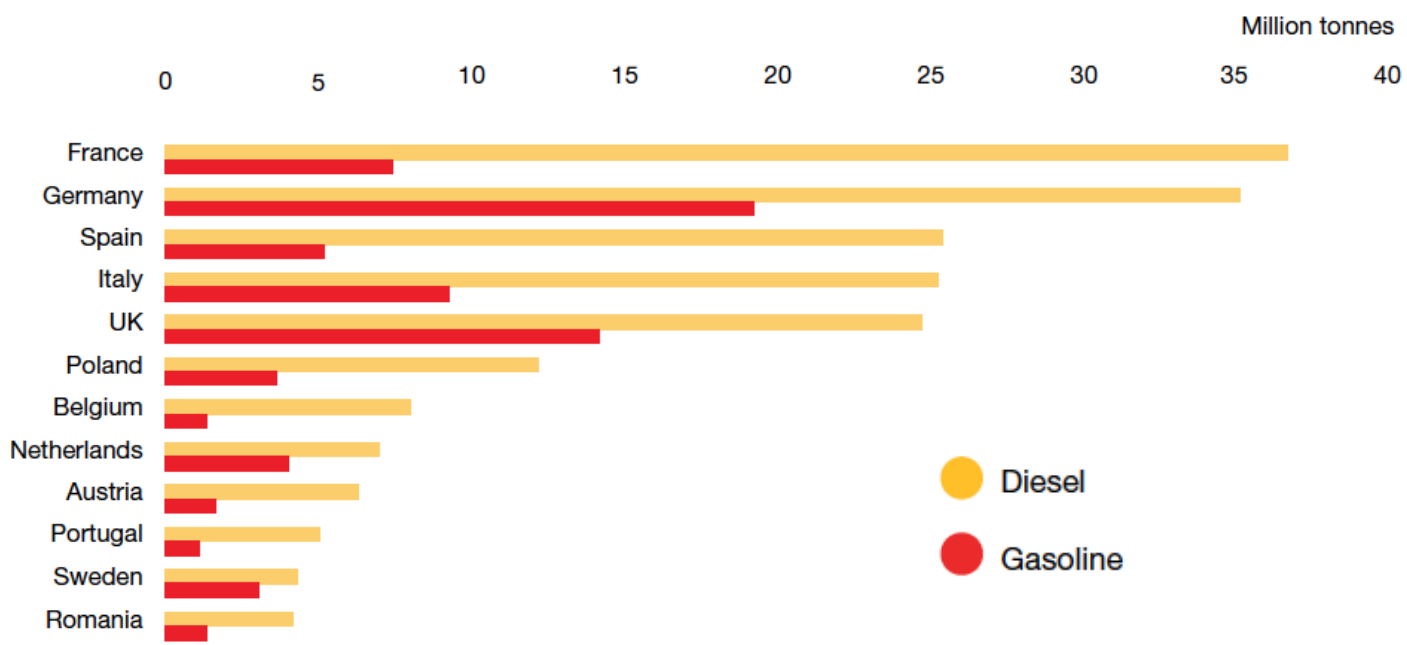

Source: Europia (2013), based on data from Woodmackenzie 

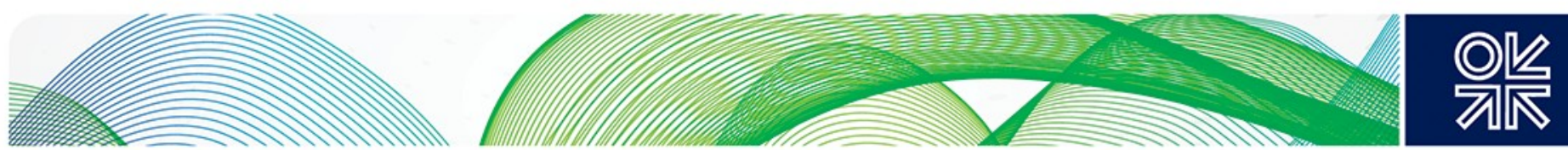

The other sector of interest for natural gas is marine shipping and inland waterways. Ships carry approximately $90 \%$ of global trade and trade has grown threefold in terms of value over the ten years to 2011. Over this period seaborne trade has increased from 29 billion ton-miles to 43 billion ton-miles - an increase of $47 \%^{22}$. During the period 2006 to 2011 , however, European maritime trade measured in tonnes fell by $7 \%$ following the economic downturn in 2008.

Total global demand for marine fuel is forecast to grow from around 200 million tonnes in 2012 to nearly $250 \mathrm{mt}$ by 2030 . EU consumption is around $28 \%$ of global consumption (58 million tonnes) and some $13 \%$ of this is diesel with the remainder being fuel oil ${ }^{23}$. Figure 5 shows the present and forecast levels of consumption (as at 2011) with more recent data confirming the projected recovery in EU demand.

Figure 5: Marine Fuel consumption in the EU

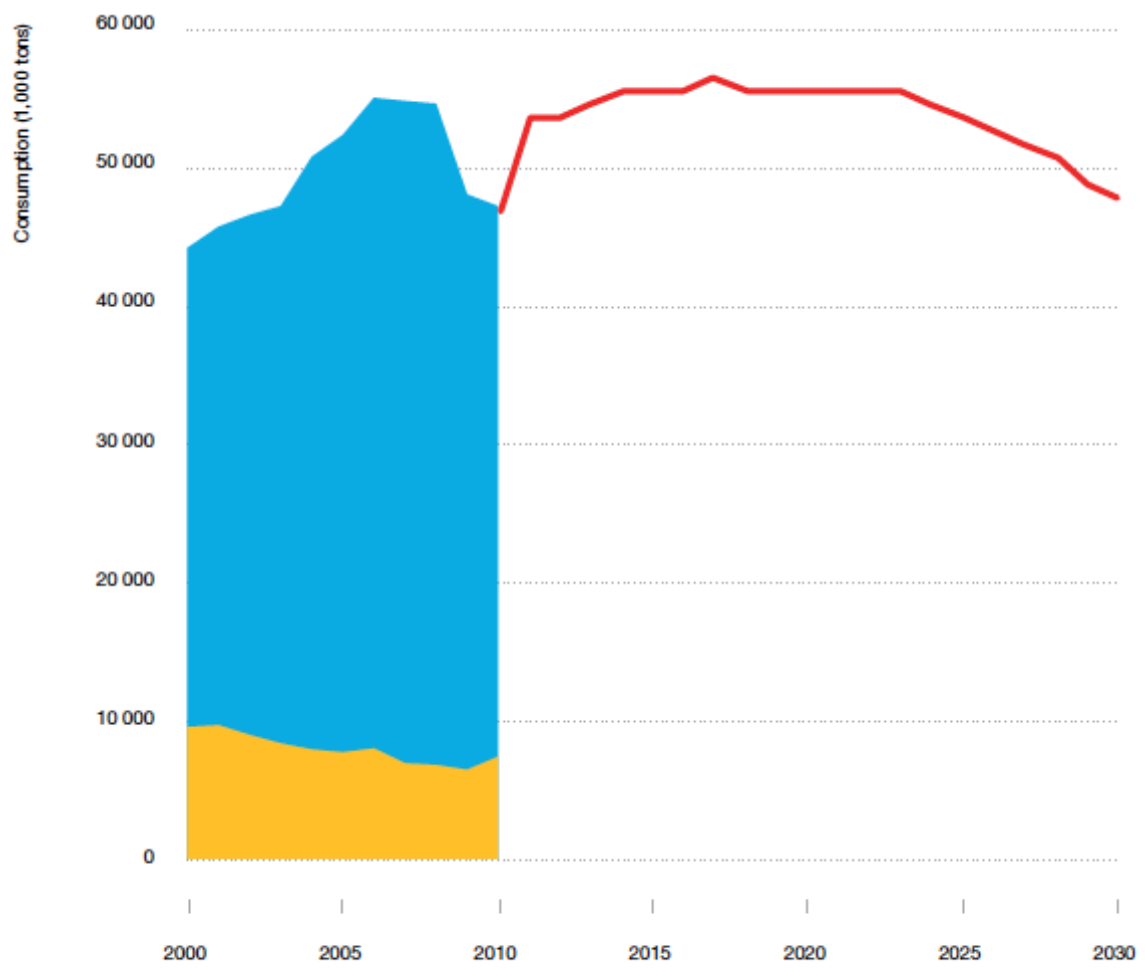

Source: Europia (2012), based on data from PFC Energy

Inland waterway transport (IWT) in Europe carries around 500 million tonnes/year ${ }^{24}$.

\footnotetext{
${ }^{22}$ UNCTAD Marine shipping statistics http://unctadstat.unctad.org/TableViewer/tableView.aspx?ReportId=32363

${ }^{23}$ Europia (2013)

${ }^{24}$ http://www.ccr-zkr.org/files/documents/om/om13_en.pdf
} 


\subsection{Summary of the role of energy in European transport}

Transportation is a major market for energy both globally and in Europe where it accounts for a third of total energy consumption and this share has been growing. Whilst transport is still heavily reliant on oil products (both globally and in Europe) the share of alternative fuels is growing, though in comparative terms natural gas is not so far making major inroads. The road market is dominated by motor gasoline (petrol) and diesel and the latter is increasing its share. The maritime market is dominated by fuel oil with gas oil a small but growing presence.

Energy demand for transport is likely to remain fairly robust in Europe though rates of growth will be minor compared to many non-OECD countries where factors such as increasing car ownership and rapid expansion in freight movements are likely to be much more significant. Whilst freight vehicles account for a relatively small share of the total vehicle parc they are likely to account for over a third of total road fuel consumption. This sector is therefore particularly important from the perspective of a new fuel seeking opportunities to build scale rapidly.

Given the scale of the transport sector there is clearly a case for gas suppliers to consider an expansion in the share taken by natural gas in Europe. The following section considers the key factors influencing the extent to which natural gas might become a more significant fuel for transportation purposes. 

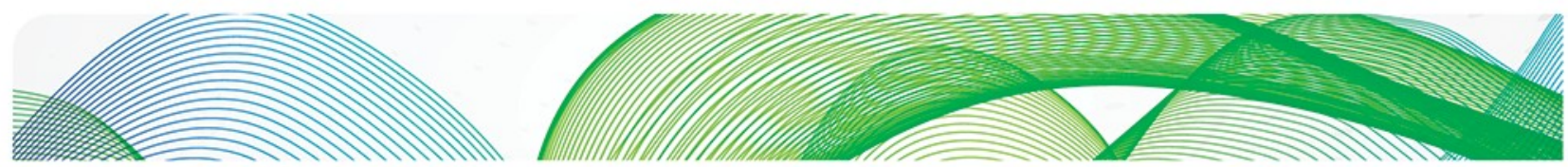

\section{An overview of the factors influencing the use of natural gas in transport}

In broad terms the case in favour of using natural gas in transportation derives from lower fuel costs and improved emissions performance when compared to current alternative oil-based products. These benefits have to be weighed against three critical issues:

- The fact that switching to natural gas will almost certainly entail higher up front vehicle costs and possibly higher repair and maintenance costs.

- Furthermore, and perhaps more critically, the so-called "chicken and egg" syndrome hampers the development of an effective refuelling infrastructure. Simply stated this refers to the unwillingness of vehicle manufacturers and/or buyers to invest in NGVs until there is a widespread network of refuelling stations whilst fuel infrastructure providers will be unwilling to make such investments until there is evidence of significant and growing NGV ownership.

- Finally switching to a new, relatively untried, fuel will always entail a degree of risk that some individuals (and more particularly companies) may be unwilling to countenance when compared with a known, safe and generally improving current option. This challenge is sometimes referred to as the "No one ever got fired for buying IBM" syndrome ${ }^{25}$ and is particularly relevant in an established sector such as transport. The market has existed for a long time and the existing fuel supply chain has become increasingly efficient and responsive to market needs. A "new" fuel such as natural gas therefore has a huge element of inertia to overcome.

This chapter sets the scene for a more detailed examination of the key factors and influences in each of the main markets by examining the main technical, infrastructural, financial and environmental factors that under pin the case for natural gas vehicles and the alternatives.

\subsection{Technical aspects}

There are a number of important technical factors that underpin the decision to use natural gas as a fuel. Whilst a detailed technical appraisal of the issues is outside the scope of this paper, this section provides an overview of the most important vehicle and fuel characteristics relating to natural gas and the main competing fuels.

\subsubsection{Vehicle and engine characteristics}

The internal combustion engine (ICE) powers almost all road vehicles and marine vessels. ICEs comprise two broad categories ${ }^{26}$.

- Spark ignition (SI) engines - ideally suited to light duty transportation uses. These engines tend to be relatively lightweight, with a wide range of revolutions per minute (RPM) and a broad torque band (i.e. capable of producing power over a relatively wide range of RPM) and can provide good performance with a minimal number of transmission gears. They are cleaner burning but thermally less efficient than compression ignition engines and not suited to high torque, low RPM applications. These engines are generally powered by petrol but the petrol can be substituted by,

\footnotetext{
${ }^{25}$ See http://corporatevisions.com/blog/2007/06/11/no-one-ever-got-fired-for-buying-ibm/ for a more detailed explanation

${ }^{26}$ See http://www.brighthubengineering.com/machine-design/1537-comparison-of-spark-ignition-si-and-compressionignition-ci-engines/
} 

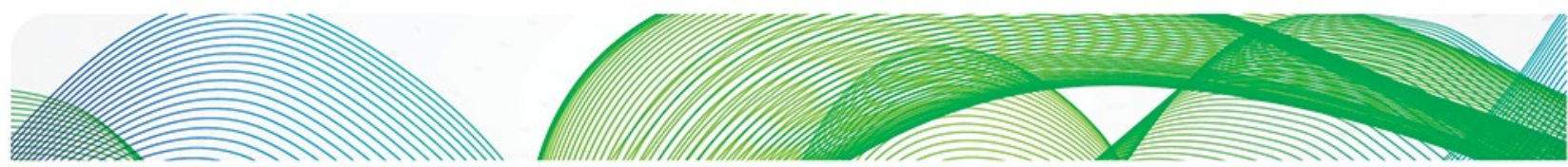

or combined with, other fuels including natural gas, $\mathrm{LPG}^{27}$, methanol, ethanol, biofuels and hydrogen

- Compression ignition $(\mathrm{Cl})$ engines - these are generally powered by diesel which self-ignites at high pressures so there is no need for a spark. $\mathrm{Cl}$ engines are heavier than $\mathrm{SI}$ engines as the compression ratio is higher - this also means the thermal efficiency of the engine is greater. Diesel can be substituted by or combined with other fuels including natural gas and biofuels.

Natural gas can therefore fuel both types of engines. A spark ignition engine is cleaner burning though there is a reduction in efficiency as a lower compression ratio is required. In heavy-duty applications, diesel engines can be configured as dual fuel or dedicated natural gas engines ${ }^{28}$.

In a dual-fuel engine the natural gas is ignited by an injection of diesel fuel - i.e. the diesel acts like a spark plug. Dual-fuelled vehicles can have variations in proportions of gas to diesel (known as the substitution rate) ranging from 45 to $95 \%$ depending on the nature of the engine. The $95 \%$ level is achieved by the recently developed high-pressure direct injection (HPDI) system developed by Westport ${ }^{29}$.

In dual-fuel applications there is an electronically controlled natural gas injection system and a separate electronic control unit (ECU) that monitors performance and controls the fuel injection. Natural gas engines used to have significantly less power and torque than conventional diesel engines though more recent designs have somewhat closed this gap ${ }^{30}$.

The choice of technology will depend on the typical gross vehicle weight, the nature of the operation (e.g. back to base) and the availability of refuelling stations. These aspects are considered in detail in section 5.4 .

Other means of propulsion for road vehicles are electric drive (often combined with a petrol or diesel hybrid) and fuel cells which are powered by hydrogen. More detail on fuels is in the following section.

Ships and inland barges are typically powered by diesel engines mainly using differing grades of heavy fuel oil (HFO) or intermediate fuel oil (IFO) which is a mixture of HFO and marine gas-oil (MGO) though some vessels and smaller craft use marine diesel or $\mathrm{MGO}^{31}$.

\subsubsection{Fuel characteristics}

The main existing and prospective fuels for transportation use are as follows:

- Petrol (gasoline in USA) ) $^{32}$ - used in spark ignition engines. Can contain up to 500 different hydrocarbons plus a range of additives to improve performance. An early problem with the spark ignition engine was that the engine would be subject to abnormal combustion known as "knocking" that is polluting, inefficient and erodes the combustion chamber. The octane rating is a measure of how resistant the gasoline is to knocking and higher performance engines require higher octane gasoline ${ }^{33}$.

\footnotetext{
${ }^{27}$ liquid petroleum gas - a generic term for ethane propane and butane mixtures that can exist as liquids at ambient temperatures and modest pressures.

${ }^{28}$ CNG services (2012)

${ }^{29} \mathrm{http} / / /$ www.westport.com/is/core-technologies/hpdi

${ }^{30}$ See http://www.cumminswestport.com/models/isx $12-\mathrm{g}$

31 US EPA (2008)

${ }^{32}$ See B. Hamilton and R. J. Falkiner, Chapter 3 in Totten et al (2003)

${ }^{33}$ http://www.unep.org/transport/pcfv/pdf/jordanwrkshp-unleaded-rafat.pdf
} 

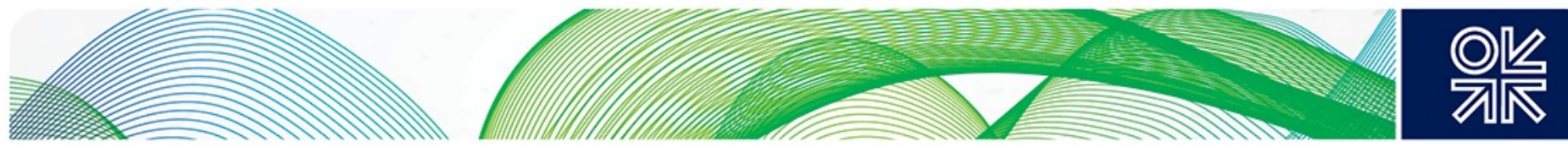

- Automotive diesel ${ }^{34}$ - a middle distillate, originally used in the manufacture of town gas (hence the name gas oil) and generally used in compression ignition engines. Distillation characteristics (i.e. volatility) are an important feature ${ }^{35}$ as there is a tradeoff between reduced power and fuel efficiency due to poor atomisation with low volatility and problems with vapour lock in the fuel system with high volatility. The distillation process is managed so that characteristics such as starting, smoke reduction and odour performance are optimised. There can be an issue over microscopic particulate emissions (PM) and $\mathrm{NO}_{x}$ emissions and these can be mitigated by a particulate filter ${ }^{36}$ and selective catalytic reduction ${ }^{37}$ (SCR) respectively. The EU has introduced progressively tighter standards for diesel fuel and engines ${ }^{38}$

- Heavy fuel oil (HFO) - often used in marine bunkers HFO is highly viscous and often contains contaminants such as sulphur. Heavy marine fuels are purified and heated on-board prior to injection into a diesel engine though there are still significant levels of $\mathrm{SO}_{x}$ and $\mathrm{NO}_{x}$ emissions.

- $\quad \mathrm{LPG}^{39}$ - referred to as Autogas in Europe. Produced as part of the natural gas liquids (NGL) stream from oil and gas fields or at refineries. There is an extensive global supply chain and LPG generally has cost and tail pipe emission advantages over gasoline and has typically been used in taxis or high mileage fleet vehicles. There are issues over filling infrastructure and the emissions advantage has been eroded by improvements in conventional engines. LPG vapour is around $50 \%$ heavier than air which has led to restrictions on LPG vehicles in tunnels, underground car parks etc.

- Natural gas - discussed further below.

- Synthetic fuel - this most commonly is either synthetic diesel or dimethyl ether (DME). Synthetic diesel is made by Fischer-Tropsch synthesis from gas (gas to liquids - GTL), coal (CTL) or biomass (BTL). DME is made from syngas and is in essence a clean burning diesel with physical properties similar to LPG ${ }^{40}$.

- Electricity - in broad terms used to power three types of vehicles - hybrids (HEV) and plug-in hybrids (PHEV) that have an alternative power source and battery vehicles $(B E V)$ that don't. HEVs charge the electric engine from the on-board internal combustion engine and plug-ins get electricity from the grid ${ }^{41}$.

- Hydrogen - can be used as a fuel directly in internal combustion engines though it is most efficient in fuel cells. Hydrogen fuel cells have many advantages - zero tail pipe emissions, reduced noise - though the development of a comprehensive production, distribution and refuelling network is still some way off

- Bio fuels - these can be blended with existing fuels or used in isolation depending upon the makeup. This category includes:

- FAME (fatty acid methyl esters) produced from oil and fats such as rapeseed, palm oil and used cooking oil. (EU production capacity around $20 \mathrm{Mtoe} / \mathrm{y}^{42}$ ) FAME is often referred to as bio diesel and most goods vehicles can run on diesel/FAME mixtures with a high proportion of the latter albeit with some reduction in range and efficiency

- Bio-Ethanol produced from sugar cane, wheat and maize. Most petrol cars in Europe can run on blends of up to $10 \%$ ethanol (E10) and research is underway into use of higher blends such as E85 (comprises $85 \%$ ethanol and $15 \%$ petrol). (EU annual production capacity around 3.7 $\mathrm{Mtoe}^{43}$ )

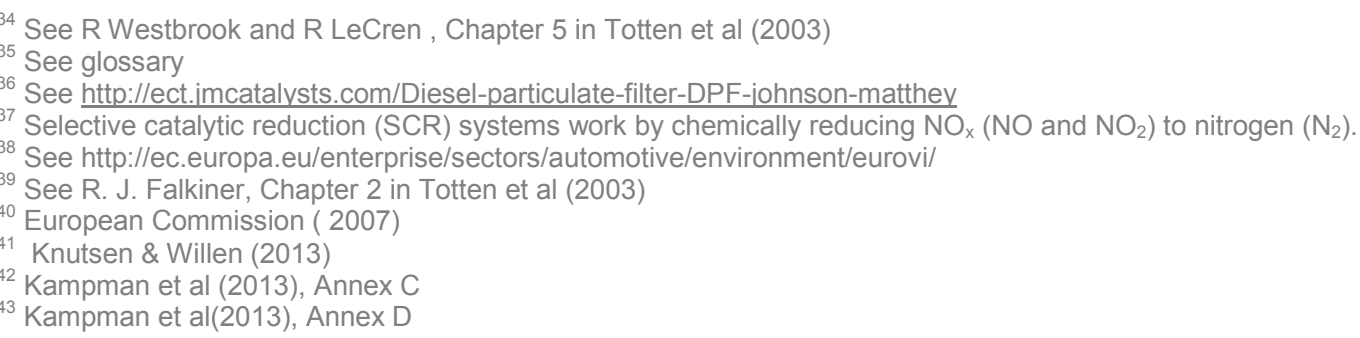



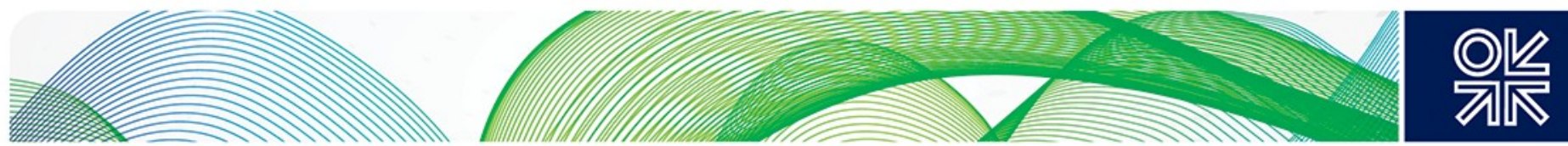

- ETBE (Ethyl tertiary butyl ether) produced from bioethanol and isobutylene used as an octane improver ${ }^{44}$,

- Biogas - derived from renewable sources such as landfill, sewage and agricultural waste with a methane content of 30 to $85 \%$ which would then be upgraded to natural gas quality (then referred to as bio-methane). Biogas is typically produced from anaerobic digestion of biomass such as food waste, manure or crop residues. Biogas can also be produced from the gasification of biomass though this is presently much costlier ${ }^{45}$

- Other biofuels include HVO (Hydro-treated vegetable oil) similar to conventional diesel, biomethanol and BTL (biomass to liquids) ${ }^{46}$

\subsubsection{CNG, LNG and biomethane}

Natural gas as a transportation fuel can be provided as compressed natural gas (CNG) or LNG. In the former case the gas is compressed to between 200 and 250 bar whereas in the latter the gas is cooled to $-162^{\circ} \mathrm{C}$ when it becomes a liquid. LNG at atmospheric pressure occupies $1 / 600$ the volume of natural gas in ambient vapour form - or put another way, it requires 3 times less volume than CNG at 200 barr $^{47}$. LNG vehicles will therefore generally have a higher range than CNG ones.

One litre of diesel fuel has the same energy as 1.7 litres of LNG. Analysis of trial data by the author suggests that typically a HDV will consume $13,500 \mathrm{btu} / \mathrm{km}$ of natural gas or 11,000 $\mathrm{btu} / \mathrm{km}$ of diesel.

In general terms LNG is preferred for marine shipping and long distance HDV road applications whilst CNG is more appropriate for smaller road vehicles and short distance 'back to depot' type operations for commercial and public transport vehicles.

LNG will typically be stored and dispensed at a temperature slightly above $-162^{\circ} \mathrm{C}$ and so some of the liquid will start to turn into gas - this is known as boil-off and causes tank pressure to increase. This "warmer" LNG is referred to as saturated or super-saturated LNG and some degree of saturation is often required in LNG-fuelled vehicles. If boil-off exceeds the vehicle's ability to cope with it - for example if it has been idle for a number of days - then gas will be vented to atmosphere, which is clearly not desirable. The management of boil-off is a critical element in the LNG supply chain.

Figure 6 provides an approximate comparison of the main transport fuels in terms of energy compared to gasoline and emissions performance. The $\mathrm{CO}_{2}$ emissions performance is calculated on a "well to wheel" (WTW) basis which is discussed further below.

\footnotetext{
${ }^{44}$ Kampman et al (2013), Annex E

${ }^{45}$ Kampman et al (2013), Annex G, see also Van Foreest 2012

${ }^{46}$ Kampman et al (2013), Annexes F, I and K

${ }^{47}$ IGU (2013), section 8
} 

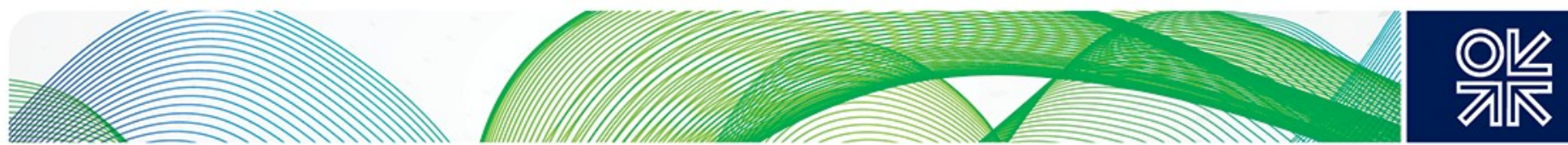

Figure 6: Fuel comparisons; energy and $\mathrm{CO}_{2}$

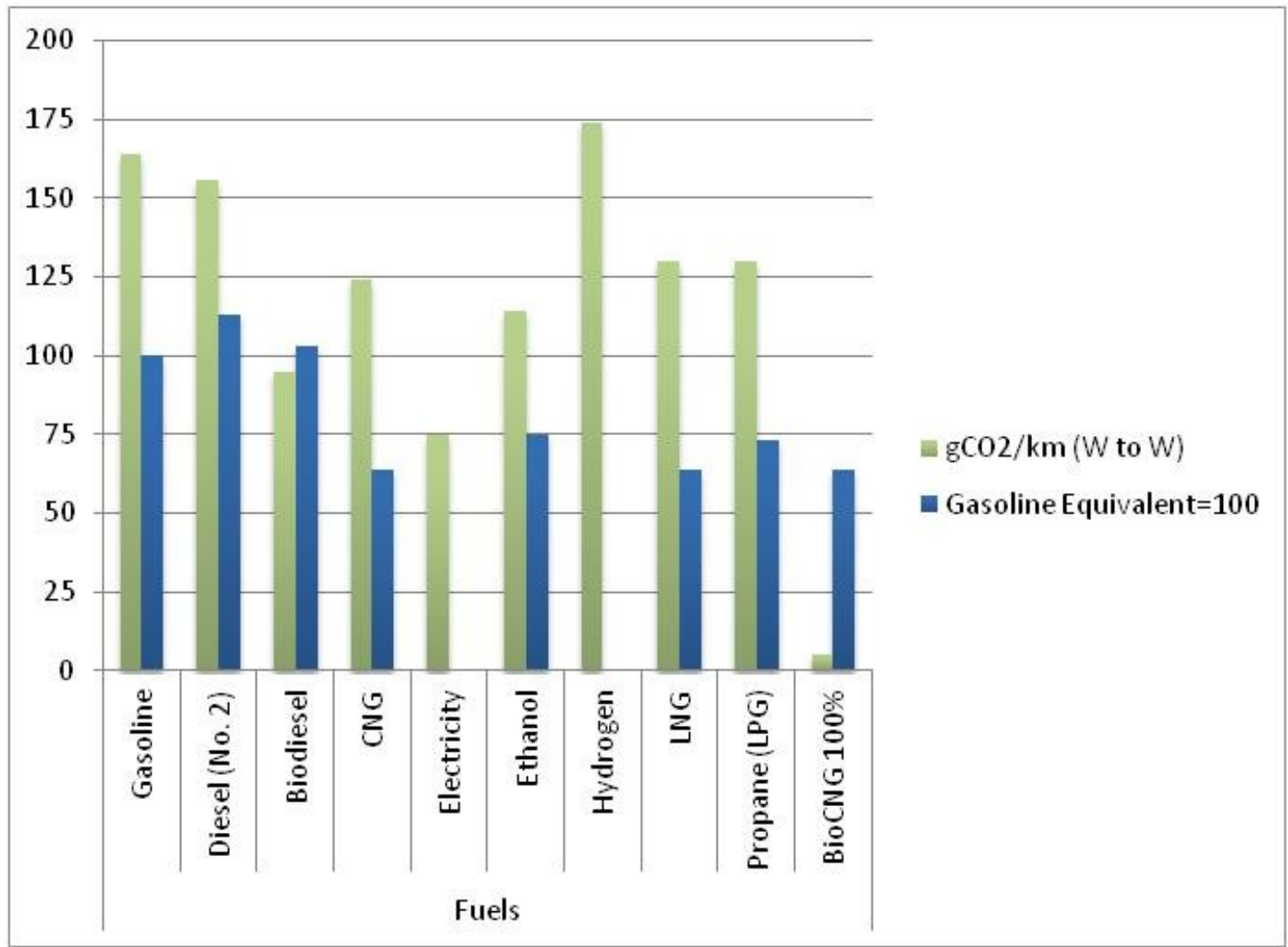

Source: DENA, US EPA and author's estimates

Biomethane is biogas that has been upgraded to grid quality. It can be supplied as a vehicle fuel in either compressed (CBG) or liquefied (LBG) form. It is normally mixed with conventional natural gas prior to dispensing. Further details on biogas are in section 3.4

The technical aspects of vehicle fuels relate both to their physical constituents and how they perform in various engine types. In broad terms diesel and gasoline represent the most efficient delivery of energy per unit of volume but have the potentially most damaging effect in terms of carbon dioxide and other emissions. Whilst natural gas is less energy intensive there are no major technical obstacles to the fuel and its environmental advantages suggest it is a realistic alternative to traditional oil-based fuels.

\subsection{Infrastructure}

\subsubsection{Road}

The critical infrastructure requirement of alternative fuel systems is a sufficiently widely dispersed re-fuelling network. "Range anxiety" - the fear that one's vehicle will run out of fuel before there is an opportunity to re-fuel - is a powerful deterrent to all unconventional forms of transportation fuel. In Europe there is already widespread infrastructure for petrol and diesel fuels; according to EUROPIA there are more than 131,000 petrol stations in Europe serving over 230 million cars ${ }^{48}$. This compares with approximately 27,500 filling stations in the EU 

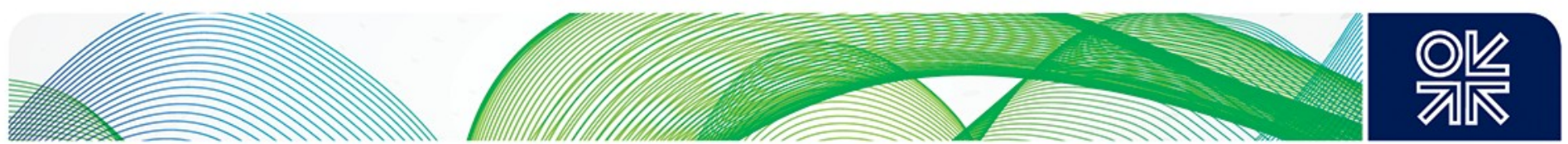

with LPG capacity and 11,000 electricity charging points ${ }^{49}$. NGVA statistics indicate that there are presently 4,274 refuelling stations in Europe (including Russia and Ukraine) of which around 40 are equipped with L-CNG capability and a similar number of LNG only stations ${ }^{50}$.

There are two basic options for natural gas refuelling stations for road vehicles:

- CNG stations comprising pressurized dispensers, a compressor capable of delivering gas at 200 bar $^{51}$ and a pipeline connection to the gas grid. Clearly the higher the pressure of the grid gas the cheaper it will be to compress the $\mathrm{CNG}^{52}$. CNG dispensers would typically be co-located with other fuels - particularly for cars and other LDVs. Where a grid connection is not possible or too expensive a "mother-daughter" configuration can be used whereby the remote station has a trailer mounted CNG tank that is delivered by road from the mother station with a second trailer operated in tandem so that the CNG station always has sufficient supplies.

- LNG stations comprising leak tight dispensers and a cryogenic tank for storing LNG which would be delivered by road tanker with a capacity of 40 to $80 \mathrm{~m}^{3}$. (This could be combined as a L-CNG station dispensing both CNG and LNG). A typical LNG refuelling station could handle 40-50 vehicles per hour ${ }^{53}$.

The European Expert Group on Future Transport Fuels notes ${ }^{54}$ that for CNG and L-CNG stations investment requirements are at least five times higher than for conventional liquid fuels and it can take up to 15 years to develop the necessary infrastructure. The European NGV industry has invested some $€ 2$ billion to establish the existing network of NG refuelling stations though there is widespread disparity in infrastructure across Europe due to differing national investment strategies and, in some cases, the availability or otherwise of economic resources. The group note that without political support and binding targets, incentives and subsidy schemes a rapid build-up of infrastructure would be difficult. A coherent policy on taxation will also be crucial.

More details on costs of gas refuelling and the present number of NGV filling stations across Europe is in section 5 .

\subsubsection{Marine}

As noted above LNG is generally preferred to CNG in marine applications. Whilst LNG-fuelled ships would require tanks up to approximately double the size of a conventional oil bunker the space requirements are well below that for CNG.

For shipping there is a range of fuelling options available. These are illustrated in Figure 7 and comprise:

- Ship-to-Ship (STS) for vessels with a bunker volume in excess of $100 \mathrm{~m} 3$ using a bunker vessel with a capacity of between 1,000 and $10,000 \mathrm{~m} 3$,

- Truck-to-Ship (TTS) for vessels with a bunker volume below $200 \mathrm{~m}^{3}$

- Bunkering directly from Terminal-to-Ship via Pipeline (TPS) suitable for all bunker volumes

\footnotetext{
${ }^{49}$ AVERE (2012)

http://www.ngvaeurope.eu/european-ngv-statistics

${ }^{51}$ According to IGU (2012) (p86) this would need a capacity of between 300 and $500 \mathrm{~m}^{3}$ per hour

52 See Baldwin \& McKeon, (2012)

${ }^{53} \mathrm{http}$ ://gasrec.co.uk/presentation/Future-Proof-Fuels-Handbook-2013.html\#p=20

${ }^{54}$ EEGFTF (2011b)
} 

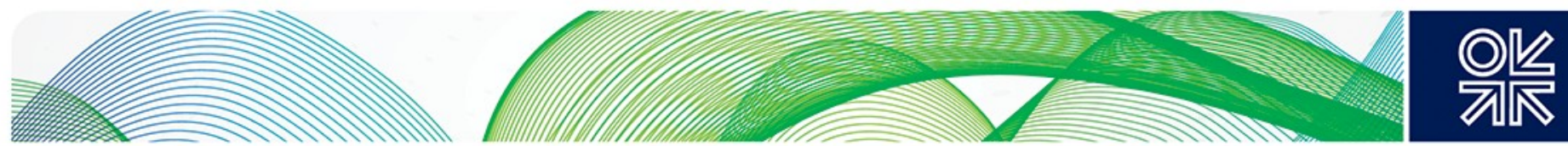

Figure 7: Alternative marine LNG bunkering solutions

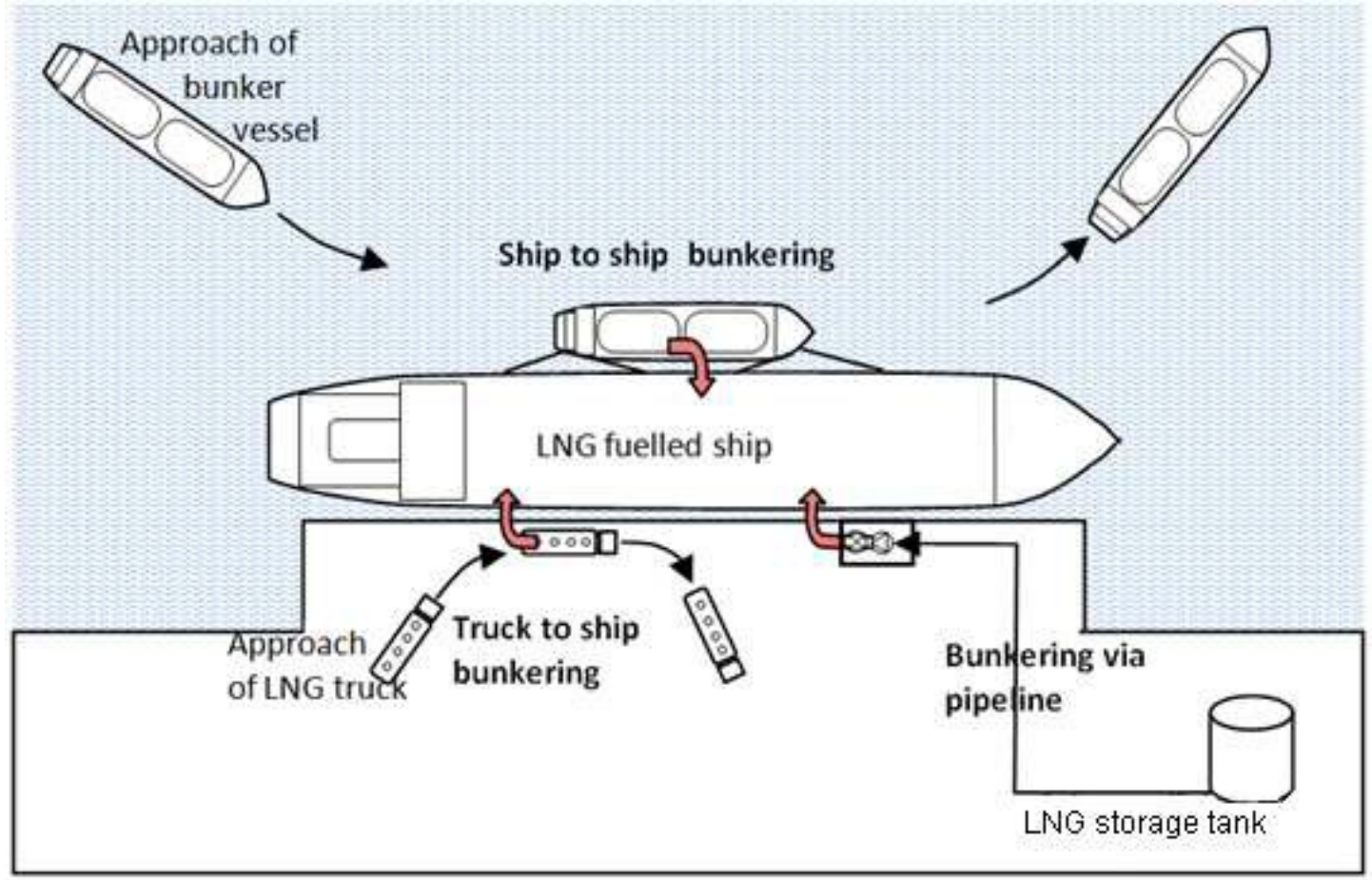

Source: Danish Maritime Authority (2011)

Capital costs will depend on the size and throughput of the facility, the configuration (i.e. are storage tanks involved) and the number of bunkering vessels required. More detail on costs is in Chapter 5.

An important starting point in building a marine LNG bunkering network will be the extent to which existing LNG import facilities can be utilised. Whilst these may not have tailor-made LNG bunkerage facilities they may well be able to facilitate ship to ship bunkering as well as transfers from LNG storage to either an LNG-fuelled ship or, more likely, a smaller LNG carrier. Discussions with operators have suggested that additional expenditure may be required to configure jetties for smaller vessels (e.g. adding fenders etc.) and there are a number of technical and regulatory issues associated with bunkering using an existing LNG import facility. Nevertheless both terminal operators and port authorities appear enthusiastic about developing a capability for LNG bunkering.

Existing LNG import facilities are shown in Figure 26.

\subsection{Standards}

In common with most industries LNG transportation is subject to a myriad of international, regional and national standards and procedures. The generalised hierarchy of regulations is shown in Figure 8 - all of these elements impact on the NGV sector. 

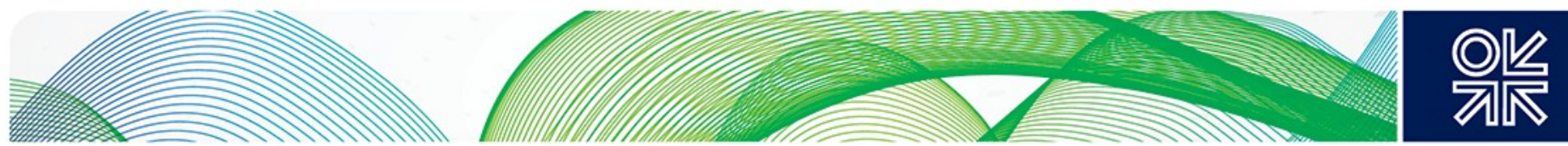

Figure 8: Regulatory framework

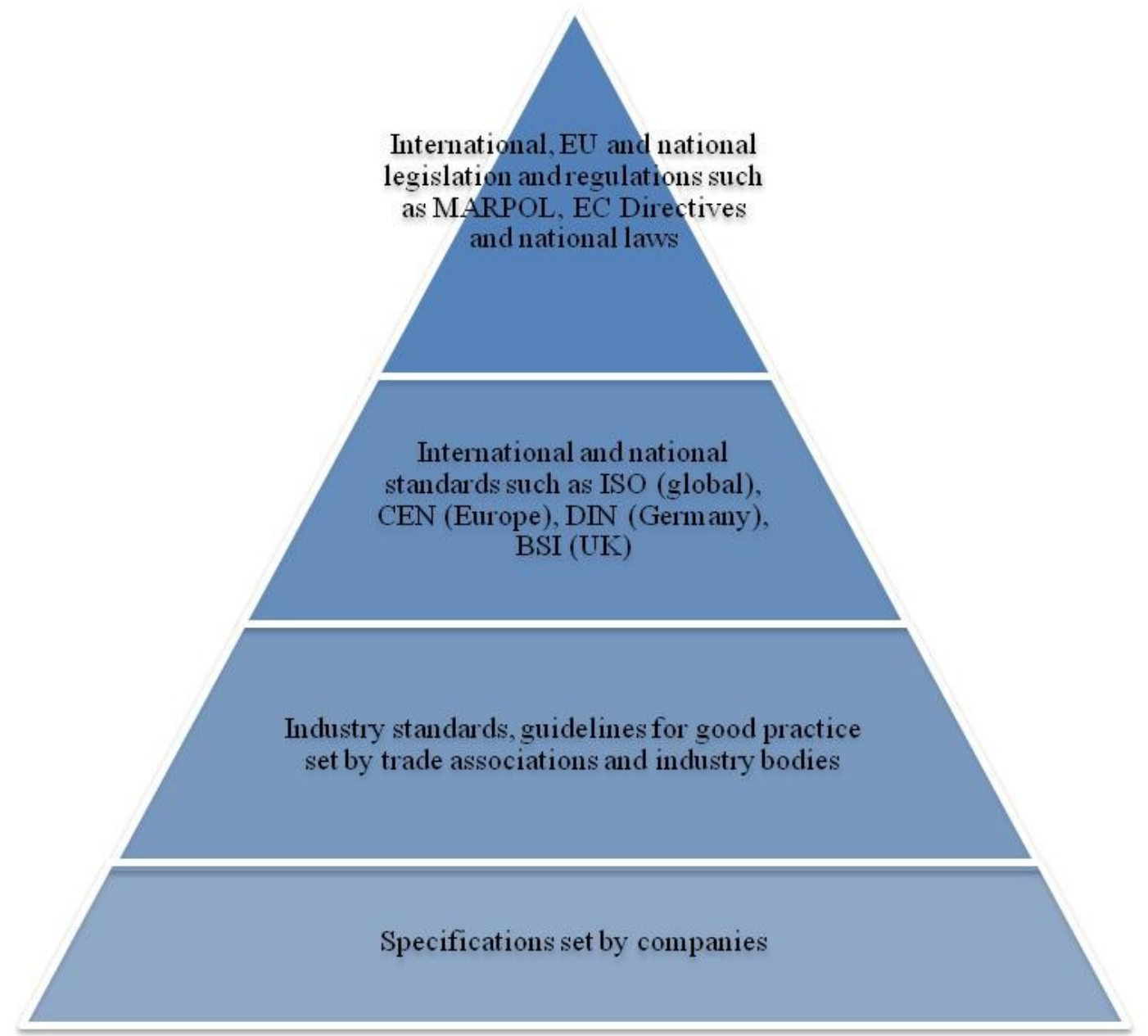

Source: Adapted from presentation by Pauwels of Netherlands Standardization Institute (NEN) at Natural Gas Vehicle Conference (25-26th Nov 20013) Amsterdam

The overall view within the industry is that standards development for the NGV sector is still at a nascent stage. Examples of some of the issues involved include:

- Standards for natural gas fuelling equipment and processes have been developed on a piecemeal basis and there is no harmonization across Europe let alone worldwide ${ }^{55}$

- Seidinger ${ }^{56}$ reports on a survey that shows that operators spend a significant sum on ensuring compliance with different regulations and standards and that the lack of harmonization is the most significant cost component - respondents claim that introducing harmonised best practice safety standards could reduce overall costs by $30 \%$.

- Custom and practice varies from country to country. For example in the UK standards for CNG filling stations are developed and maintained by the Institution of Gas Engineers and Managers (IGEM ${ }^{57}$ ) whilst those for LNG are set by the British Compressed Gases Association $\left(\mathrm{BCGA}^{58}\right)$.

\footnotetext{
${ }^{55}$ Example national standards include DVGW G651 in Germany and TSA 2010 in Sweden

${ }^{56}$ Writing in IGU (2013) p105

${ }^{57}$ http://igem.org.uk/

${ }^{58}$ http://www.bcga.co.uk/
} 

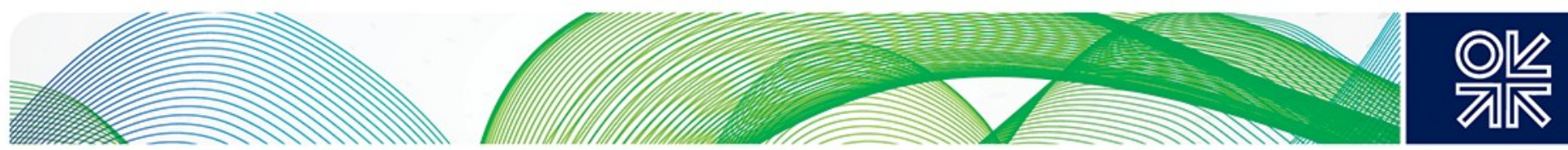

The concern over standards is borne out by discussion held by the author with operators. Particular issues that need to be resolved in the road sector include:

- A harmonised filling station standard for CNG and L-CNG refuelling stations

- A harmonised approval procedure for dual fuel applications

- CNG and LNG repair and enclosed parking facilities

- EU standards for biomethane

A further concern is the variable treatment of requests for new filling stations from local planning authorities. This is particularly an issue for LNG refuelling stations where the technology is unknown to most authorities and some appear to be at a loss as to how to deal with the applications.

The EN standard for CNG refuelling points is due to be adopted in 2014. According to the European Commission it is expected that:

- ISO/DIS 16923 standard for CNG and ISO/DIS 16924 for LNG/LCNG could be adopted in the second half 2014.

- $\quad$ ISO/DTS 18683 "Guidelines for systems and installations for supply of LNG as fuel to ships" is also expected for approval in the second half 2014.

- The process of transposition of ISO standards to CEN (i.e. European) standards is under discussion.

- $\quad$ ISO TC 22/SC 25 series of working groups covering different fuels and other committees covering gas cylinders, internal combustion engines, cryogenic vessels and natural gas fuelling stations are, by and large, at the approvals stage prior to publication

- A UN Regulation, R110, which deals with CNG components is due to be extended to LNG vehicles ${ }^{59}$

In the marine sector many of the existing procedures for LNG handling are based on existing rules and procedures for land-based installations. As a result there is a lack of harmonized bunkering procedures and vessels must adopt different procedures and technical requirements at each port, permit procedures are extended and layover times can be increased as some ports do not allow LNG bunkering during loading or when passengers are on board (unlike oil bunkering) ${ }^{60}$. Public perceptions of LNG as a dangerous fuel also play a role.

Gap analysis undertaken on behalf of the European Maritime Safety Agency (EMSA) has highlighted a number of issues regarding maritime regulations for LNG as a bunker fuel.

- Only interim guidelines exist under IMO rules though an 'International Code of safety for ships using gases or other low flashpoint fuels (IGF Code)' is under development and will cover safety and operational issues for gas-fuelled seagoing vessels, though it will not cover the transfer system.

- SIGTTO guidelines do exist though these relate to LNG as a cargo ${ }^{61}$ and would need adapting for bunkering procedures.

- Transport of LNG by inland tankers is presently not allowed within the EU though one vessel is operating in The Netherlands

\footnotetext{
59 http://www.globalautoregs.com/rules/121

${ }^{60}$ European Commission (2013c)

${ }^{1}$ International Society of Gas Tanker and Terminal Operator
} 

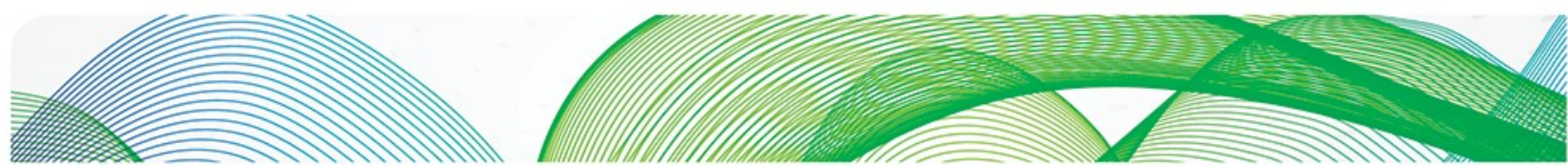
on

Plans to progress matters are in hand. In particular:

- $\quad$ By mid 2014 the ISO is due to finalise a global ISO guideline on LNG storage and bunkering; ${ }^{62}$

- $\quad$ During 2014 the IMO will finalise the International Code on Safety for Gas-Fuelled Ships (IGF-Code) covering all aspects of ship design and on-board use of LNG;

- By end 2014 the European Commission, in cooperation with EMSA will, based on the results of work mentioned above, propose a comprehensive set of rules, standards and guidelines for LNG provision, bunkering and use in shipping;

- $\quad$ By 01 Jan 2020: All TEN-T core ports will have to provide LNG refuelling facilities.

Whilst much work is evidently underway the sector is likely to remain confronted with differing and overlapping standards and procedures for some time to come.

\subsection{Environmental aspects}

The environmental performance of transport modes is a crucial area and one subject to a wide range of analytical challenges. In broad terms the key elements relate to the emissions of carbon dioxide $\left(\mathrm{CO}_{2}\right)$, nitrous oxides $\left(\mathrm{NO}_{\mathrm{x}}\right)$ and particulates. However methane is also an important greenhouse gas (GHG) so any emissions that might be associated with either the dispensing or incomplete combustion of natural gas - referred to as methane slip - should also be captured. GHGs are typically measured on a $\mathrm{CO}_{2}$ equivalence basis as shown in Table 6.

Table 6: Greenhouse gas coefficients

\begin{tabular}{|l|l|}
\hline Greenhouse Gas & $\mathrm{CO}_{2}$ Equivalent $\left(\mathrm{CO}_{2} \mathrm{eq}\right)$ \\
\hline $\mathrm{CO}_{2}$ & 1 \\
\hline Methane $\left(\mathrm{CH}_{4}\right)$ & 25 \\
\hline Nitrous Oxide $\left(\mathrm{N}_{2} \mathrm{O}\right)$ & 298 \\
\hline
\end{tabular}

Source: Edwards et al (2013)

Particulate emissions (caused by the incomplete combustion of fuel) are of concern because diesel particulates are easily inhaled into the lower respiratory tract and have been found to contain potentially carcinogenic organic compounds ${ }^{63}$. Diesel engines produce more particulate matter than petrol engines.

The following sections examine the specific issues relating to road and marine transport in more detail.

\subsubsection{Road Transport}

There are two main dimensions to the measurement of emissions from road transportation:

- Fuel related factors

- Vehicle related factors

-

\footnotetext{
62 (ISO TC67/WG10 is currently working on such a guideline which will comprise safety, security and training).

${ }^{63}$ http://www.hse.gov.uk/foi/internalops/ocs/200-299/oc292_2.htm
} 

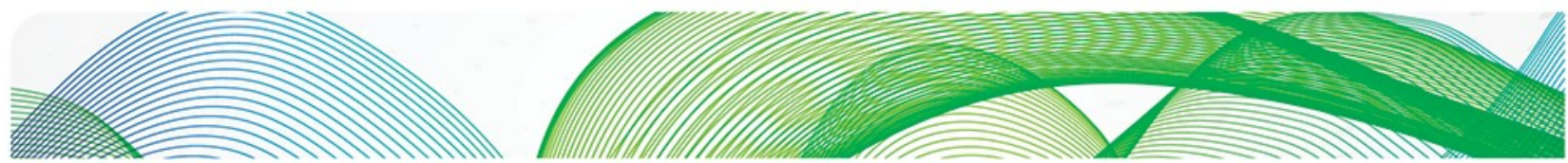

Evaluation of fuel performance is complicated by whether it is measured on:

- a tank to wheel (TTW) basis, (often referred to as tailpipe measurement) or

- a well to wheel (WTW) basis which incorporates the entire life-cycle of the fuel from production to combustion including extraction, separation and treatment, transportation, refining and distribution to the tank of the relevant vehicle ${ }^{64}$.

Some fuels show a significantly different performance when measured on one basis versus another.

With regard to gas the well to tank (WTT) comparison - i.e. CO2 emissions resulting from moving the gas from its source to the tank of a vehicle, the JEC consortium ${ }^{65}$ has analysed the situation for a range of fuels and different pathways and the results are shown in Table 7 . For gasoline and diesel the figures represent the emissions associated with crude oil for a typical EU source that is then transported and refined in the EU and then distributed to final customers. The pathways for natural gas reflect different sources as shown in the table and include assumptions regarding fugitive emissions of methane from production, transmission and distribution.

Table 7: Well to tank and combustion comparison

\begin{tabular}{|l|c|c|}
\hline Fuel pathway & WTT $\left(\mathrm{gCO}_{2} \mathrm{eq} / \mathrm{MJ}\right)$ & $\begin{array}{l}\text { Total } \mathrm{GHG} \text { inc combustion } \\
\left(\mathrm{gCO}_{2} \mathrm{eq} / \mathrm{MJ} \text { final fuel }\right)\end{array}$ \\
\hline $\begin{array}{l}\text { EU supply mix (2500km pipeline) to } \\
\text { CNG }\end{array}$ & 13.0 & 69.3 \\
\hline W Siberia to CNG $(7000 \mathrm{~km})$ & 22.6 & 77.6 \\
\hline Caspian to CNG (4000km) & 16.1 & 71.1 \\
\hline LNG (ex M East) to CNG & 21.1 & 76.1 \\
\hline LNG (ex M East) to LNG retail & 19.4 & 74.5 \\
\hline EU Shale gas to CNG & 7.8 & 62.8 \\
\hline C-Biomethane from wet manure & -69.9 & -69.9 \\
\hline C-Biomethane from organic waste & 14.8 & 14.8 \\
\hline Diesel & 15.4 & 88.6 \\
\hline Gasoline & 13.8 & 87.1 \\
\hline LPG & 8.0 & 73.7 \\
\hline
\end{tabular}

Source: Edwards et al (2011)

${ }^{*}$ Closed digestate storage

It should be noted that bio-methane generates a negative number (i.e. a $\mathrm{CO}_{2}$ credit) on a WTT basis as it is utilising material that would otherwise add to GHG emissions and the $\mathrm{CO}_{2}$ from combustion is not counted, as it is $100 \%$ renewable. There are clearly additional environmental benefits from biomethane ${ }^{66}$ particularly when assessed on a well to wheel basis. However, as Van Foreest notes ${ }^{67}$ biogas production in Europe requires subsidies to attract investors and establish a substantial scale. Some of these incentives (e.g. in the UK) are such that it is generally more attractive to utilise the biogas in a CHP scheme or to inject it into the existing natural gas grid and thereby supply all gas users with a blend of biogas and

\footnotetext{
${ }^{64}$ See Nicotra A. in IGU (2012)

${ }^{65}$ This group comprises the EU Joint Research Centre plus EUCAR and CONCAWE. See http://www.eucar.be/newsand-events/August $\% 202013 \% 20$ JEC $\% 20$ Consortium for full details

${ }^{6}$ Biomethane refers to biogas that has been treated to grid quality

${ }^{67}$ Van Foreest (2012)
} 

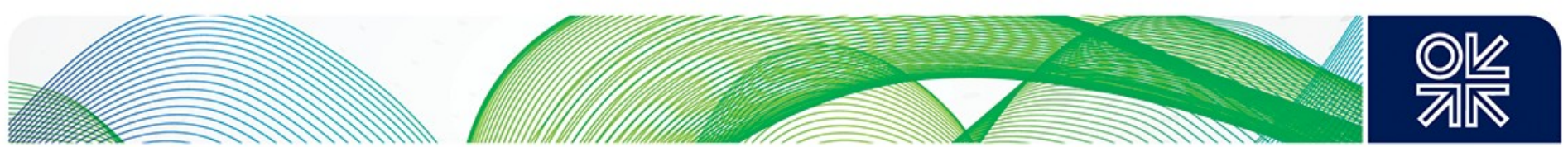

conventional natural gas. Incentives can be subject to change and Government and public views on biofuels more generally are not always positive.

Nevertheless there is significant enthusiasm for using biomethane in the transport sector though as Van Foreest points out a very optimistic scenario is required to envisage a total market share for biogas of 10 to $20 \%$. It would appear therefore that whilst biogas will play a niche role in the transport sector it will only be part of the NGV mix and so claims regarding well to wheel emissions performance should be weighted accordingly.

Turning to the vehicle related aspects it should be noted that present EU legislation focuses on tailpipe emissions and EU legislation adopted in 2011 sets emission performance standards for cars and light commercial vehicles (LCVs). Measurement of $\mathrm{CO}_{2}$ emissions from HDVs is much harder as there are huge differences depending upon the nature of the operation and the time the vehicle is utilised and to date the focus has been on reducing emissions of nitrogen oxides and particulates. This has resulted in a new norm for HGV fuels known as Euro $\mathrm{VI}^{68}$.

Maedge and Lage ${ }^{69}$ point out when comparing NG or biomethane with diesel on a tailpipe basis it yields a $\mathrm{CO}_{2}$ saving of between 3 and $8 \%$ - much below that if the comparison is made on a well to wheel basis. This is also a reason why retrofitting to CNG/LNG is presently not attractive for environmental reasons.

A more detailed consideration of the role that environmental issues play in determining vehicle and fuel choices is set out in section 5 .

\subsubsection{Marine Transport}

The main concerns relating to marine transport have focussed on sulphur oxide $\left(\mathrm{SO}_{\mathrm{x}}\right)$ and nitrogen oxide $\left(\mathrm{NO}_{\mathrm{x}}\right)$ emissions from ship exhausts. The International Maritime Organisation's (IMO) International Convention for the Prevention of Pollution from Ships known as MARPOL addresses the issue of pollution from ships. MARPOL Annexe $\mathrm{VI}^{70}$ requires that the level of sulphur emissions applicable in Emission Control Areas (ECAs) - these include the Baltic Sea and the North Sea - were capped at $1 \%$ on 1 July 2010 (from the original 1.50\%) being further reduced to $0.10 \%$, effective from 1 January 2015 .

MARPOL VI means that vessels entering the ECAs have three alternatives:

- Install scrubbers which remove $\mathrm{SO}_{2}$ from the exhaust gas (though there are issues over how the waste sulphur is handled

- Burn costlier MGO (marine gas oil)

- Convert to LNG

The relative merits of these options are considered in more detail in section 5 .

Separately the energy efficiency design index (EEDI) requirements were introduced by the IMO in January 2013. This sets a formula for $\mathrm{CO}_{2}$ emissions from new build vessels and presently applies to tankers, gas carriers, bulk carriers, general cargo ships, refrigerated

\footnotetext{
${ }^{68}$ See http://ec.europa.eu/enterprise/sectors/automotive/environment/eurovi/

${ }^{69}$ Writing in IGU (2012)

${ }^{70}$ IMO (2011)
} 

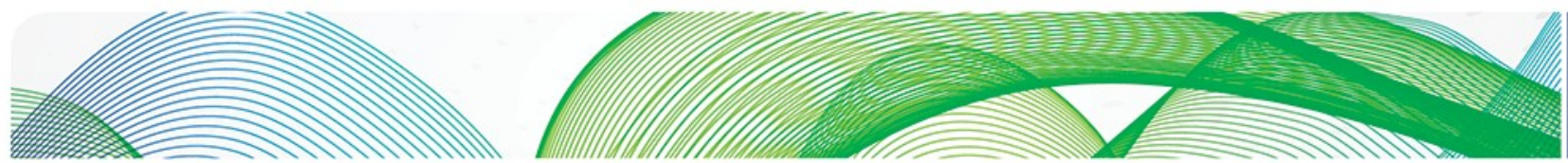

cargo carriers and container ships that together account for around $70 \%$ of emissions from new ships ${ }^{71}$.

\subsection{Financial and commercial}

The economics of switching to natural gas for all users is primarily a trade-off between the differential between natural gas and gasoline, diesel or fuel oil prices and the additional capital (and possibly running) cost of a new LNG/CNG vehicle or vessel. In addition the overall economic case for natural gas will have to include the additional costs of building and operating the required infrastructure - these costs may be passed on directly to the user.

This study looks at the financial case in detail for each of the modes below and this section focuses on some general points regarding pricing and costs.

\subsubsection{Pricing}

In essence there are two key factors impacting on pricing - the commodity element and the role of taxation.

In wholesale commodity price terms diesel or gas-oil has generally traded at a significant premium to gas prices as shown in Figure 9 - particularly when compared to NBP (UK) and recent BAFA (German border) prices.

Figure 9: Selected oil and gas prices

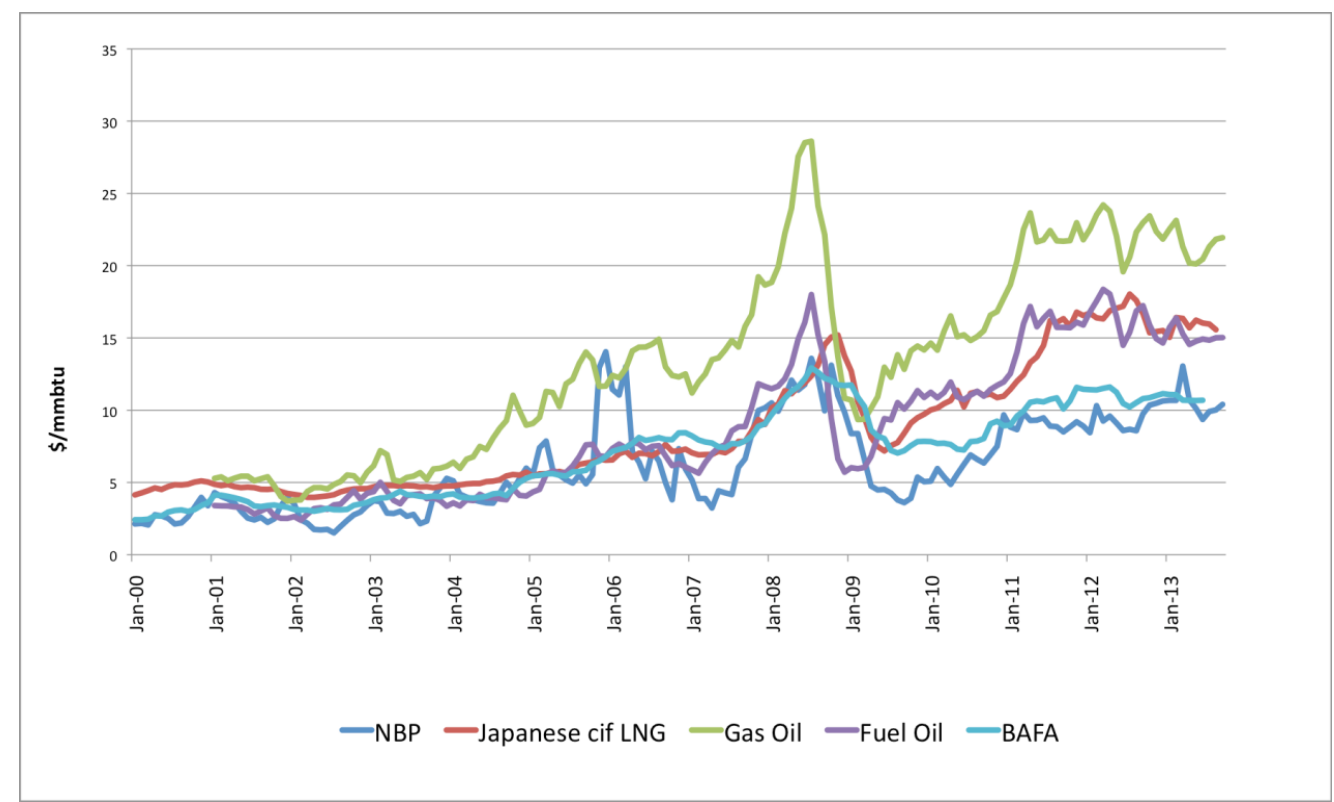

Source: Petroleum Argus

Figure 10 shows some selected differentials between gas oil and NBP and Henry Hub (to indicate the difference in the road transportation sector) and between fuel oil and NBP and

${ }^{71}$ http://www.imo.org/KnowledgeCentre/PapersAndArticlesByIMOStaff/Documents/A\%20new\%20chapter\%20for\%20 MARPOL\%20Annex\%20VI\%20-\%20E\%20Hughes.pdf 

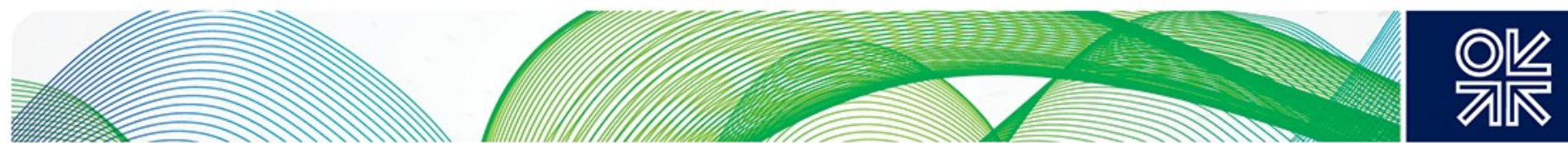

Japanese LNG prices (to indicate potential differences in the marine sector). The NBP diesel differential has generally been positive and in recent years mostly above $\$ 5 / \mathrm{mmbtu}$. Where the differential has narrowed it has usually been a temporary phenomenon as a result of a sudden collapse in diesel prices that take some time to feed through to gas prices due to the indirect influence of time lags in continental European gas contracts. Fuel oil differentials to NBP are less marked and have generally been below $\$ 5 / \mathrm{mmbtu}$ or negative.

Figure 10: Selected gas and oil product price differentials

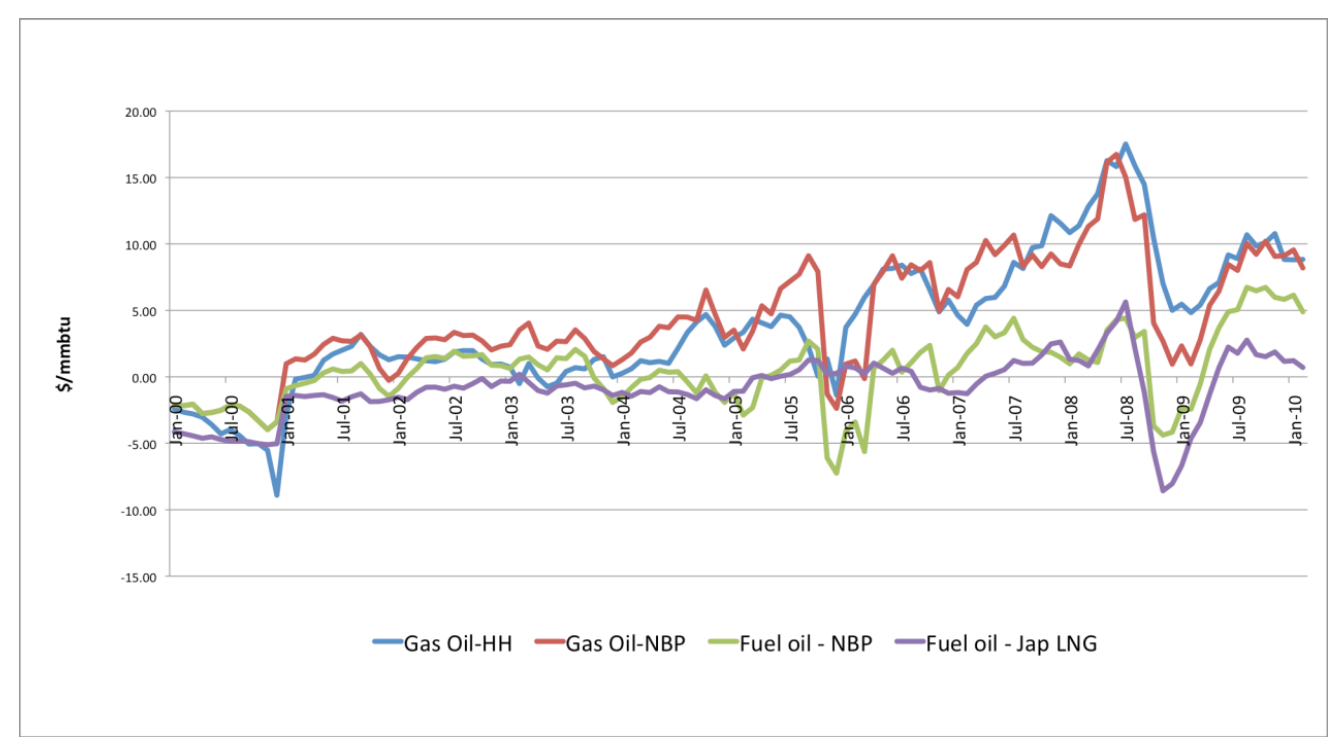

Source: Petroleum Argus

The prices shown are all wholesale prices and exclude retail costs and taxation - this latter element is particularly important in road transportation in Europe. This is illustrated in Figure 11 which shows a calculation by Citi (2013) of the build-up of prices for diesel and LNG in the UK based on an assumed oil price of $\$ 100 / \mathrm{bbl}$ and landed LNG prices closer to forecast Asian levels rather than NBP.

\section{Figure 11: Estimated split for retail UK LNG and diesel}

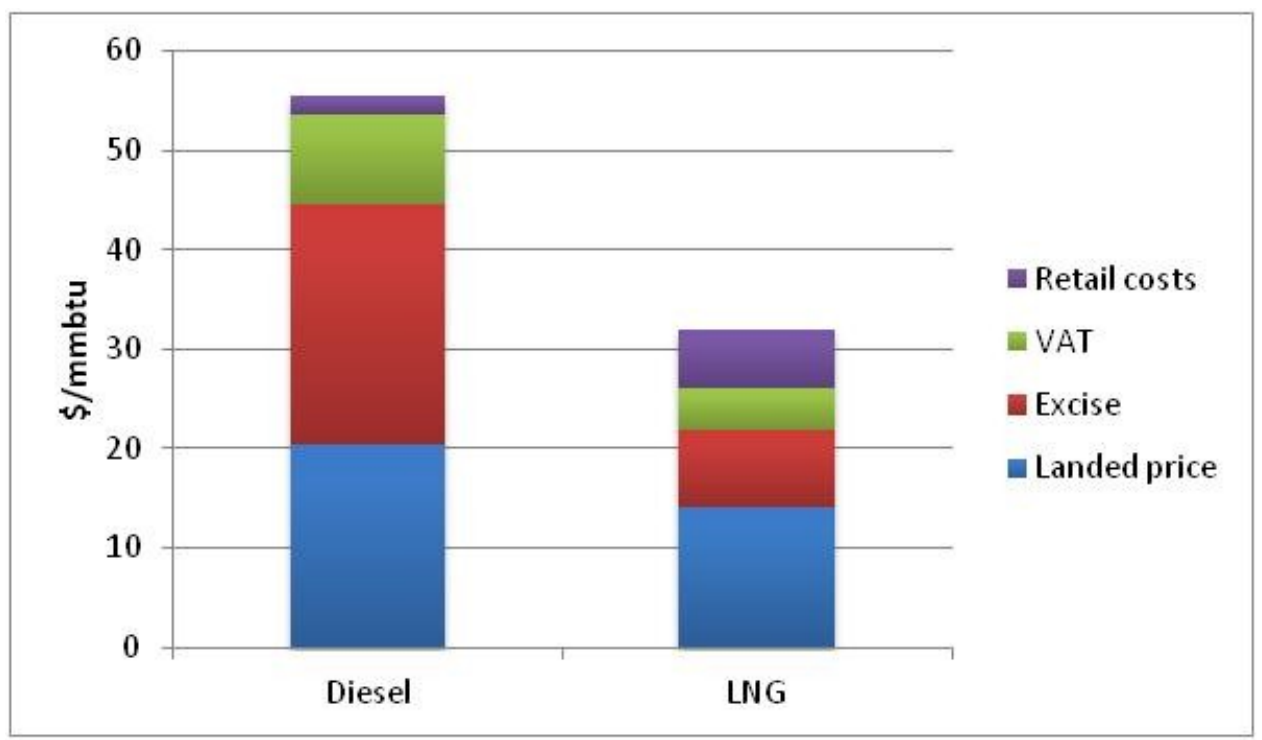

Source: Citi (2013) 

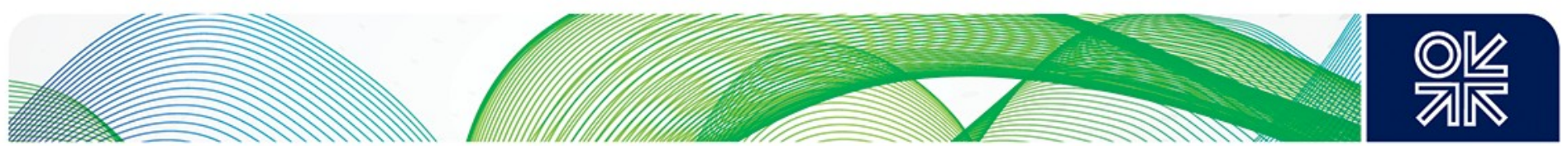

Figure 11 demonstrates the significant role played by excise duties that account for $76 \%$ of the differential between final diesel and LNG prices, with commodity prices accounting for the remaining $24 \%$. It should be noted that the retail costs are broad estimates and the higher retail costs for LNG may not be justified in the long run.

To further illustrate the importance of the fiscal impact the author has calculated the impact of tax rates per kilometre for an HDV using $100 \%$ diesel versus $100 \%$ natural gas. The results are shown in Table 8 - it should be noted that published excise rates are in €/litre for diesel and $€ / G J$ for natural gas. In all the countries shown the difference in tax rates is worth at least $€ 0.1$ per kilometre and over double that in the UK. This issue is considered again in section 5 .

Table 8: Comparison of vehicle fuel tax rates for selected European countries

\begin{tabular}{|l|r|r|r|r|r|r|}
\hline \multirow{2}{*}{} & \multicolumn{1}{|c|}{$€ /$ litre } & \multicolumn{1}{|c|}{$€ /$ GJ } & \multicolumn{2}{|c|}{ Tax in $\$ / \mathrm{mmbtu}$} & \multicolumn{2}{c|}{ Tax in $€ / \mathrm{km}$} \\
\cline { 2 - 8 } & Diesel & NG & Diesel & NG & Diesel & NG \\
\hline France & 0.428 & 0 & 17.1 & 0.0 & 0.14 & 0.00 \\
\hline Germany & 0.46 & 3.86 & 18.4 & 5.6 & 0.15 & 0.05 \\
\hline Netherlands & 0.44 & 5.29 & 17.6 & 7.6 & 0.14 & 0.08 \\
\hline UK $^{*}$ & 0.67 & 6.59 & 26.8 & 9.5 & 0.21 & 0.09 \\
\hline
\end{tabular}

Source:http://ec.europa.eu/taxation_customs/resources/documents/taxation/excise_duties/energy_prod ucts/rates/excise_duties-part_ii_energy_products_en.pdf and author's calculations. Note VAT is excluded.

${ }^{*}$ converted at $£ 0.8=€ 1$

The economics in the marine sector are not influenced to the same degree by fiscal issues as generally bunker fuel is free of any taxes. Marine bunkers typically account for between 25 to $50 \%$ of ship operating costs so any fuel cost saving would be very important. The key driver in marine will be the difference between LNG prices and heavy fuel oil (HFO) - typically with a $1 \%$ sulphur content. As Figure 10 shows the spread between the two will vary around the world and through time. It is likely that legislation restricting the use of HFO on environmental grounds will be a more important factor than the cost of the fuel and in future spreads between natural gas and MGO will be more relevant.

\subsubsection{Costs}

The main elements of cost (other than fuel) to be considered are the vehicle procurement costs, repairs and maintenance and the capital and operating costs associated with refuelling. These are considered in detail for the different modes in the following sections.

It should be noted that the cost associated with differential levels of GHGs has not been included in the calculations. The EU has extended the EU Emissions Trading Scheme to the aviation industry from January 2013, though following representations from the aviation sector this only applies to intra-EU flights ${ }^{72}$. Moves to bring road transport within the ETS have not made progress due primarily to objections from the industry which has pointed out that transport fuels are already heavily taxed ${ }^{73}$. Whilst some form of carbon pricing would enhance the advantage of natural gas over diesel/gasoline in most cases it would also enhance the attraction of other alternative fuels.

\footnotetext{
${ }^{72}$ http://www.carbontrust.com/resources/reports/advice/eu-ets-the-european-emissions-trading-scheme

${ }^{73} \mathrm{http}: / /$ ec.europa.eu/clima/events/0071/beddoes_en.pdf
} 

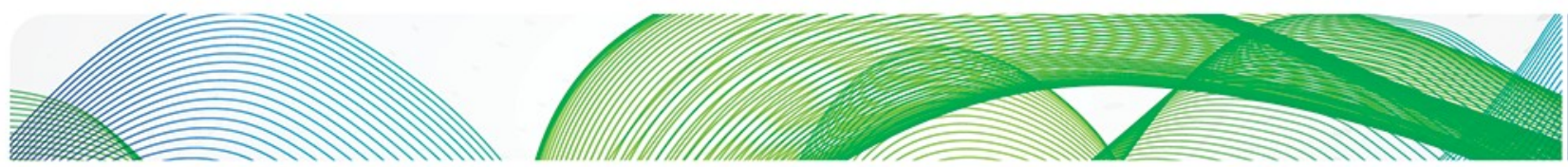

\subsection{Summary of the factors influencing the use of natural gas in transport}

This chapter has considered the main technical, infrastructural, financial and environmental factors that underpin the choice of fuels for transportation and how the case for natural gas vehicles can be made in this regard.

- In technical terms there are no major obstacles facing gas as a fuel though diesel and gasoline represent the most efficient delivery of energy per unit of volume. The infrastructure requirements for refuelling road-based natural gas vehicles are well understood for both CNG and LNG options though coverage across Europe is patchy and well below the level provided for petroleum products. Marine-based LNG refuelling is undeveloped though a range of configurations could be relatively quickly established.

- Industry standards for the NGV sector are still at a nascent stage and whilst much work is evidently underway differing and overlapping standards and procedures are likely to be a feature for some time to come.

- The environmental performance of transport modes is a crucial area both in terms of the general contribution to GHGs but also the impact of air pollution on public health. Whilst natural gas is less polluting (lower $\mathrm{CO}_{2}$ and $\mathrm{NO}_{x}$ emissions and zero particulate matter) than petroleum products methane itself is a potent GHG so tight control of the supply and combustion process is vital. Evaluation of the environmental performance of a fuel can be on a tank to wheel (TTW) or a well to wheel (WTW) basis and the impact of the latter is particularly profound with regard to bio-fuels. However a total market share for biogas in the gasfuelled transport sector in excess of $20 \%$ is unlikely. In the marine sector the legislative drive to remove sulphur pollution from ship exhausts is an important factor favouring natural gas

- The financial and commercial case for natural gas in transport is primarily a trade-off between the differential between natural gas and oil product prices and the additional capital (and possibly running) cost of a new LNG/CNG vehicle or vessel. The wholesale price of natural gas is typically at a discount to gas-oil prices though the differential to fuel oil is less marked. There is a significant discount to petroleum retail prices, which is strongly influenced by differential tax rates, and the future level of fuel taxation is a crucial issue in the road sector. In addition the overall economic case for natural gas will have to include the additional costs of building and operating the required infrastructure.

On balance it would appear that the key issues relating to the choice of natural gas as a transportation fuel are primarily financial and environmental. Other issues such as standards and technical suitability can also be important - particularly in the short term - where user experience can be critical in determining the rate of take up in a new fuel.

The issue of user experience and how this can impact on the extent to which NGVs can expand their market share raises the question of what is the present status of NGVs both globally and in Europe? This is considered in the next chapter. 

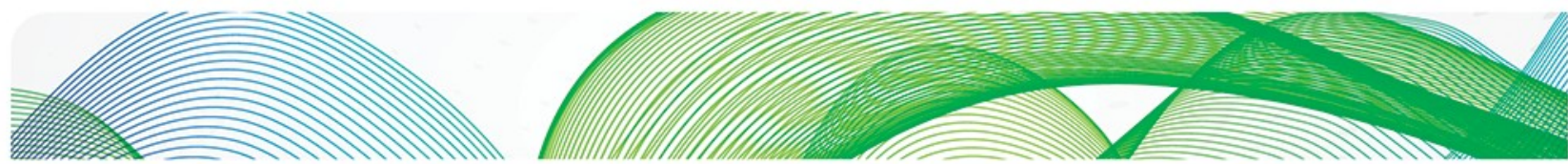

\section{The present status of gas in transportation}

This section provides an overview of the NGV market globally and in Europe. Developments in some European countries are also looked at in more detail in order to provide examples of the type of activities that are presently underway and the role of the European Commission is considered in some detail.

\subsection{Overview of global usage}

\subsubsection{Road transportation}

Natural gas is used as a vehicle fuel in many countries and has for many years performed this role. According to the latest statistics from Natural Gas Vehicles Association Europe (NGVA) there are some 17.73 million NGVs worldwide of which some 16.3 million are light duty vehicles ${ }^{74}$. The number of vehicles is concentrated in a relatively small number of countries with 10 nations accounting for around $86 \%$ of all registered NGVs and three (Iran, Pakistan and Argentina) for $47 \%$ of the world total. The top ten countries and how the $86 \%$ is distributed between them is shown in Figure 12.

Figure 12: Leading NGV countries (\% of population of NG vehicles in the top 10 countries)

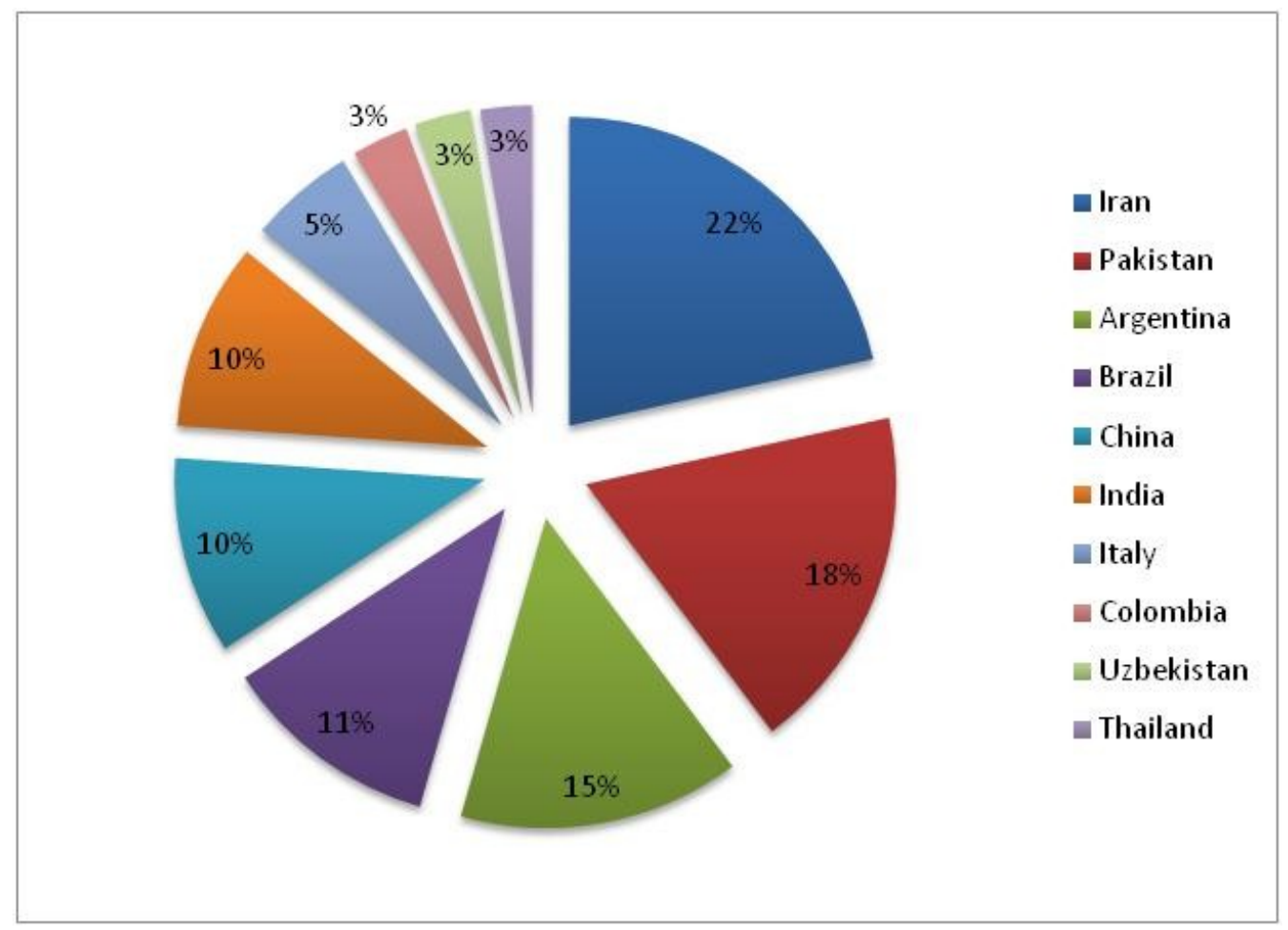

Source: NGVA and Gas Vehicles Review: http://www.ngvaeurope.eu/worldwide-ngv-statistics

\footnotetext{
${ }^{74}$ Worldwide NGV statistics provided by NGVA Europe and the GVR, http://www.ngvaeurope.eu/worldwide-ngvstatistics. Note the figures shown are the latest available though the actual date varies from country to country.
} 

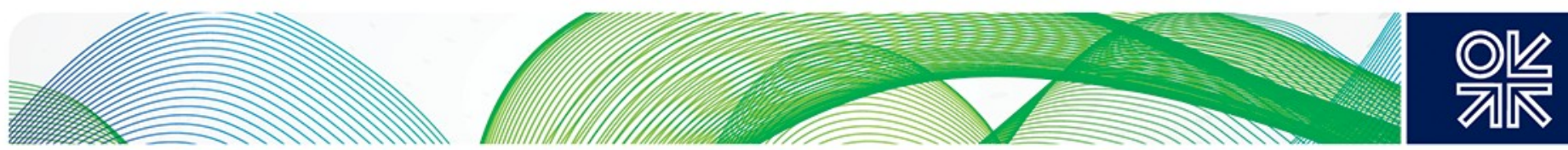

As would be expected most of the leading NGV countries are significant gas producers though production in Argentina is falling ${ }^{75}$. It is also to be noted that only two of the leading countries (Italy and Ukraine) are located in the European region.

Given the uneven distribution of NGVs it would be expected that the share of total vehicle population held by natural gas vehicles is very low in most countries. Those where NGVs account for a share in excess of $10 \%$ are shown in Table 9 . The IGU indicate that in all of these countries there is strong government support underpinning the NGV sector ${ }^{76}$.

Table 9: Countries with an NGV population in excess of $10 \%$

\begin{tabular}{|l|r|r|r|}
\hline Country & \multicolumn{1}{|c|}{$\begin{array}{c}\text { Total vehicle } \\
\text { population ('000) }\end{array}$} & $\begin{array}{c}\text { Total NGV } \\
\text { population ('000) }\end{array}$ & NGVs shares (\%) \\
\hline Pakistan & 3,276 & 2,610 & $79.7 \%$ \\
\hline Bangladesh & 293 & 182 & $62.1 \%$ \\
\hline Armenia & 440 & 244 & $55.5 \%$ \\
\hline Bolivia & 906 & 255 & $28.1 \%$ \\
\hline Iran & 12,182 & 3,300 & $27.1 \%$ \\
\hline Uzbekistan & 1,700 & 450 & $26.5 \%$ \\
\hline Argentina & 12,800 & 2,244 & $17.5 \%$ \\
\hline Colombia & 2,918 & 451 & $15.4 \%$ \\
\hline Peru & 1,505 & 158 & $10.5 \%$ \\
\hline
\end{tabular}

Source: NGVA and GVR : http://www.ngvaeurope.eu/worldwide-ngv-statistics

Figure 13: NGV growth rates by region

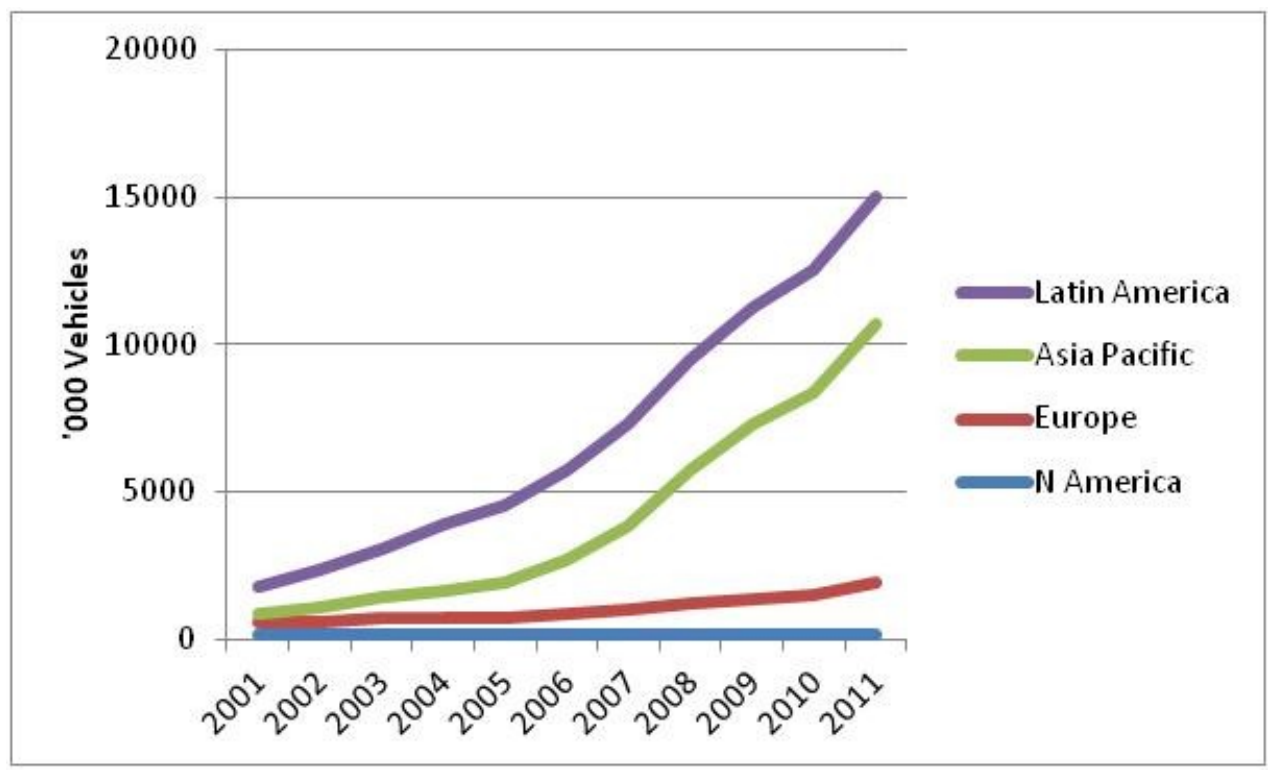

Source: NGVA http://www.ngvaeurope.eu/worldwide-ngv-statistics 

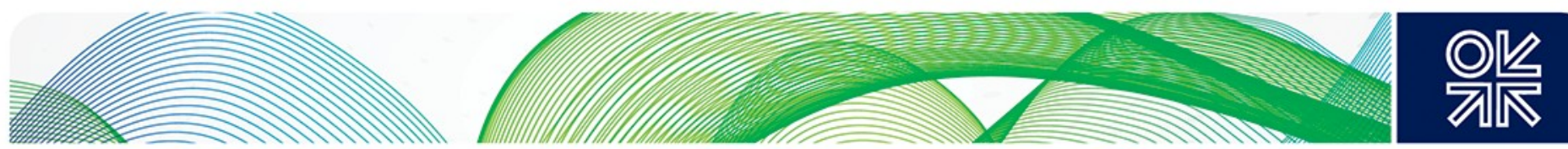

It is clear from Figure 13 that the number of NGVs has grown rapidly in recent years in some regions with NGV Global reporting an annual growth rate of 23\% between 2001 and $2011^{77}$. This compares with a global annual rate of growth in new registrations of $2.5 \%$ for cars and $4.1 \%$ for trucks over the period 1990 to $2011^{78}$. Figure 13 shows the wide range of growth in NGVs by region and the relatively sluggish growth in Europe.

\subsubsection{Marine transportation}

The market for natural gas in marine applications is still relatively undeveloped - particularly outside Europe - though it represents an increasingly attractive sector.

As shown in Section 2.1 the global marine fuel market is some 240 million tonnes $(\mathrm{mt})$ of which $180 \mathrm{mt}$ is supplied by fuel oil with the remainder being of marine gasoil. EU consumption is around $50 \mathrm{mt}$. The fuel consumption of a container ship is roughly equivalent to about the demand of $3,500 \mathrm{HDVs}^{79}$ so volumes could grow rapidly if the sector becomes established.

\subsection{NGVs in Europe}

In addition to activity levels the other significant factor impacting on energy demand in transport is the policies adopted by national governments and supranational bodies. This section considers the institutional framework shaping the environment for NGVs and in particular the role of the European Commission. The section also considers specific initiatives by countries and industry bodies.

\subsubsection{The role of the European Commission}

In a European context the role of EU policy will be most significant though as noted below the International Maritime Organisation (IMO) also has a strong influence on the demand for energy in the shipping sector.

EU policy with regard to fuel in transport is driven by two main objectives ${ }^{80}$.

- A desire to reduce dependence on imported oil for transportation where it accounted for an import bill of $€ 1$ billion per day in 2011 and a deficit in trade balances of some $2.5 \%$ of EU GDP ${ }^{81}$ and

- The reduction of vehicle emissions which account for around $20 \%$ of the EU's total $\mathrm{CO}_{2}$ emissions and are increasing ${ }^{82}$, in order to achieve the gradual decarbonisation of transport

There are a wide range of policies and initiatives arising from the energy, climate and mobility and transport departments aimed at achieving these objectives. This study has identified the following main policy areas that are likely to have the greatest impact on natural gas in transportation.

\footnotetext{
${ }^{77}$ http://www.iangv.org/current-ngv-stats/

${ }^{78}$ Davis et al (2013)

${ }^{79}$ Citi (2013)

${ }^{80}$ See http://ec.europa.eu/transport/themes/urban/cpt/

${ }^{81}$ European Commission (2013a) (COM 17) page 2

${ }^{82}$ See http://ec.europa.eu/clima/policies/transport/index en.htm
} 

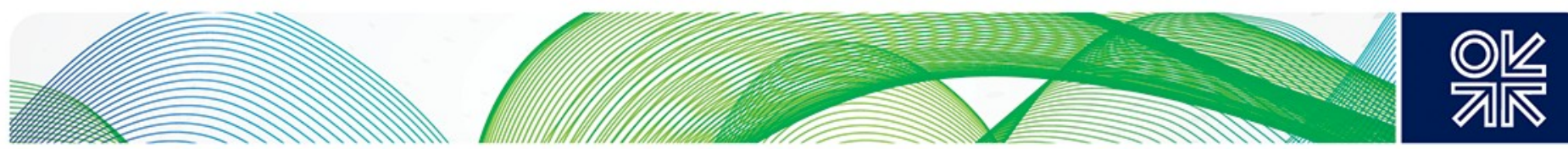

- A white paper was published in 2011 entitled "Roadmap to a Single European Transport Area - Towards a competitive and resource efficient transport system"83, which suggested that by 2030 the use of conventionally fuelled cars in urban transport would be halved and phased out completely by 2050 .

- The Fuel Quality Directive ${ }^{84}$, which sets tougher standards regarding pollutants in fuels and which, together with the Renewable Energy Directive, targets a 10\% share of energy from renewable sources in transport in Community energy consumption by $2020^{85}$. These regulations include the so called Euro VI standards aimed at reducing emissions of nitrogen oxides and particulate matters from trucks and buses from January 2013, measures regarding biofuels ${ }^{86}$ and a requirement to introduce sulphurfree fuels.

- $\quad \mathrm{CO} 2$ emissions legislation ${ }^{87}$ setting emission performance standards for new passenger cars requires a fleet average emission of $130 \mathrm{~g}$ of CO2/km for new passenger cars to be fully achieved by 2015 . Similar rules apply to vans.

- Clean power for transport: - this comprises a European alternative fuels strategy ${ }^{88}, a$ proposal for a Directive on the deployment of an alternative fuels infrastructure ${ }^{89}$ and a statement of actions required to enable the uptake of LNG in the shipping sector ${ }^{90}$ where the EU is targeting a $40 \%$ reduction in GHG emissions.

- The Seventh Framework Programme (FP7) designed to establish technologies necessary to adapt the current energy system into a more sustainable one ${ }^{91}$. This initiative covers a large number of research projects across the whole spectrum of sustainable energy and includes funding for the LNG Blue Corridors research project ${ }^{92}$. This project is discussed in more detail below.

- European strategy on clean and energy efficient vehicles ${ }^{93}$ - the strategy has the objectives of promoting a manufacturing sector based on clean and energy efficient vehicles, taking a global lead in the deployment of alternative, sustainable, propulsion technologies and creating a green economy aimed at the decarbonisation of transport. The focus appears to be primarily on electric vehicles

- The Trans-European Network for Transport Innovation and New Technologies (TENT) which establishes a core transport network and can provide funding for NGV related projects ${ }^{94}$ such as the GARneT programme and Blue Corridors project (discussed below).

Other regulations and related projects include

- Requirements for organisations (whether operators or contracting entities) to take into account lifetime energy costs and emission impacts when purchasing fleet road transport vehicles ${ }^{95}$

- Requirements for ship operators to report $\mathrm{CO}_{2}$ emissions ${ }^{96}$

- The EU Transport GHG: Routes to 2050 project ${ }^{97}$ aimed at prioritising transportation initiatives - now completed

\footnotetext{
European Commission (2011)

${ }^{84}$ European Commission (2009a)

${ }^{85}$ European Commission (2009b)

86 There has been much criticism of the potential impact on agriculture and biodiversity of crop based biofuels - in September 2013 the European

Parliament agreed to limit the contribution of traditional biofuels to $6 \%$ of the amount of food that can be used to meet the overall 10 percent target for renewable energy in transport by 2020 . http://www.ebb-

eu.org/pressdl/Monitoring\%20EP\%20Vote\%2020130916.pdf

${ }^{87}$ Regulation (EC) No 443/2009

${ }^{88}$ European Commission (2013a) (COM 17)

89 European Commission (2013b) (COM 18)

90 European Commission (2013c) (SWD 4)

91 See http://ec.europa.eu/energy/technology/fp7_en.htm

92 See http://www.Ingbluecorridors.eu/

93 See http://ec.europa.eu/enterprise/sectors/automotive/competitiveness-cars21/energy-efficient/

${ }^{94} \mathrm{http}: / /$ ec.europa.eu/transport/themes/infrastructure/index en.htm

95 2009/33/EC http://eur-lex.europa.eu/LexUriServ/LexUriServ.do?uri=OJ:L:2009:120:0005:0012:en:pdf

96 See http://ec.europa.eu/clima/news/articles/news_2013062801_en.htm
} 

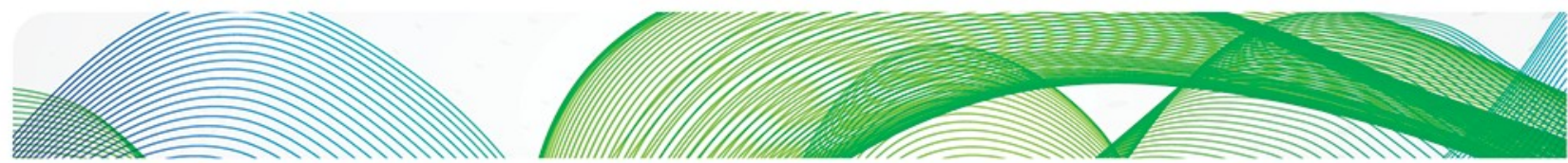

With regard to fuel taxation there were proposals to raise minimum taxation levels for natural gas but this has been postponed and member states can apply exemptions to vehicle fuel taxes for natural gas until $2023^{98}$.

\subsubsection{Industry initiatives}

The Natural and Bio Gas Vehicle Association for Europe (NGVA Europe) is the leading industry group advocating the use of methane (both natural and bio) in transportation across Europe. Membership includes vehicle manufacturers, gas producers and suppliers and a range of service providers. NGVA presently has 159 members from 40 different countries and produces a wide range of technical and statistical information on the use of and prospects for methane in transportation ${ }^{99}$.

NGVA Europe engages actively with the European Commission responding to consultations and in developing projects such as LNG Blue Corridors.

The LNG Blue Corridors project aims to exploit the know-how and expertise of the various stakeholders in NGVs and LNG infrastructure. The project will develop a demonstration project over four years covering four main corridors (see Figure 14) connecting 12 member states. A parallel work stream will be aimed at developing a new generation of Euro VI dual fuelled and dedicated LNG vehicles. The partners intend to invest $€ 14.3$ million, of which $€ 8$ million will be funded by the European Commission ${ }^{100}$.

Started in early 2013 the first steps will be to establish 14 new LNG/L-CNG stations for around 100 trucks $^{101}$. Partners include natural gas companies such as Fluxys, GasNatural Fenosa and GDF SUEZ, vehicle manufacturers such as Volvo, Renault and Iveco and intermediaries such as GasRec, Linde (BOC) and Ballast Nedam.

The Blue Corridors project will also focus on key technical issues such as:

- Improved efficiency of vehicles and engines

- Reductions in LNG boil off in vehicle tanks

- Standardisation of fuel tanks, connections and systems and regulations for vehicles and refuelling stations.

The project is seeking vehicle fleet operators to participate in the project.

\footnotetext{
${ }^{97}$ See http://www.eutransportghg2050.eu/cms/about-the-project/ no update since summer 2012

${ }^{98}$ IGU (2012), p13

${ }^{99} \mathrm{http} / / /$ www.ngvaeurope.eu/

${ }^{100}$ Presentation by X Ribas of Idiada at Natural Gas Vehicle Conference Amsterdam(25-26th Nov 2013)

$101 \mathrm{http}: / /$ www.Ingbluecorridors.eu/
} 

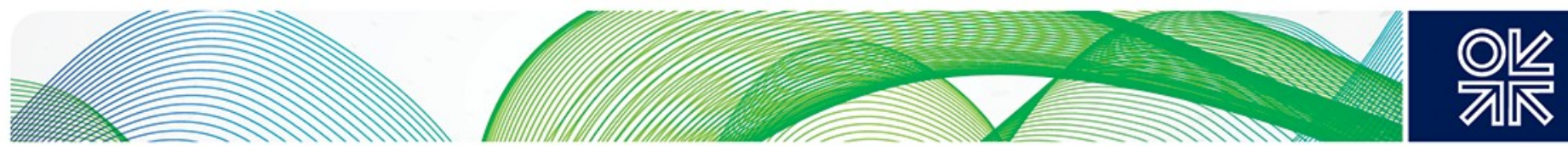

Figure 14: The four "Blue corridors" proposed for 2016/17

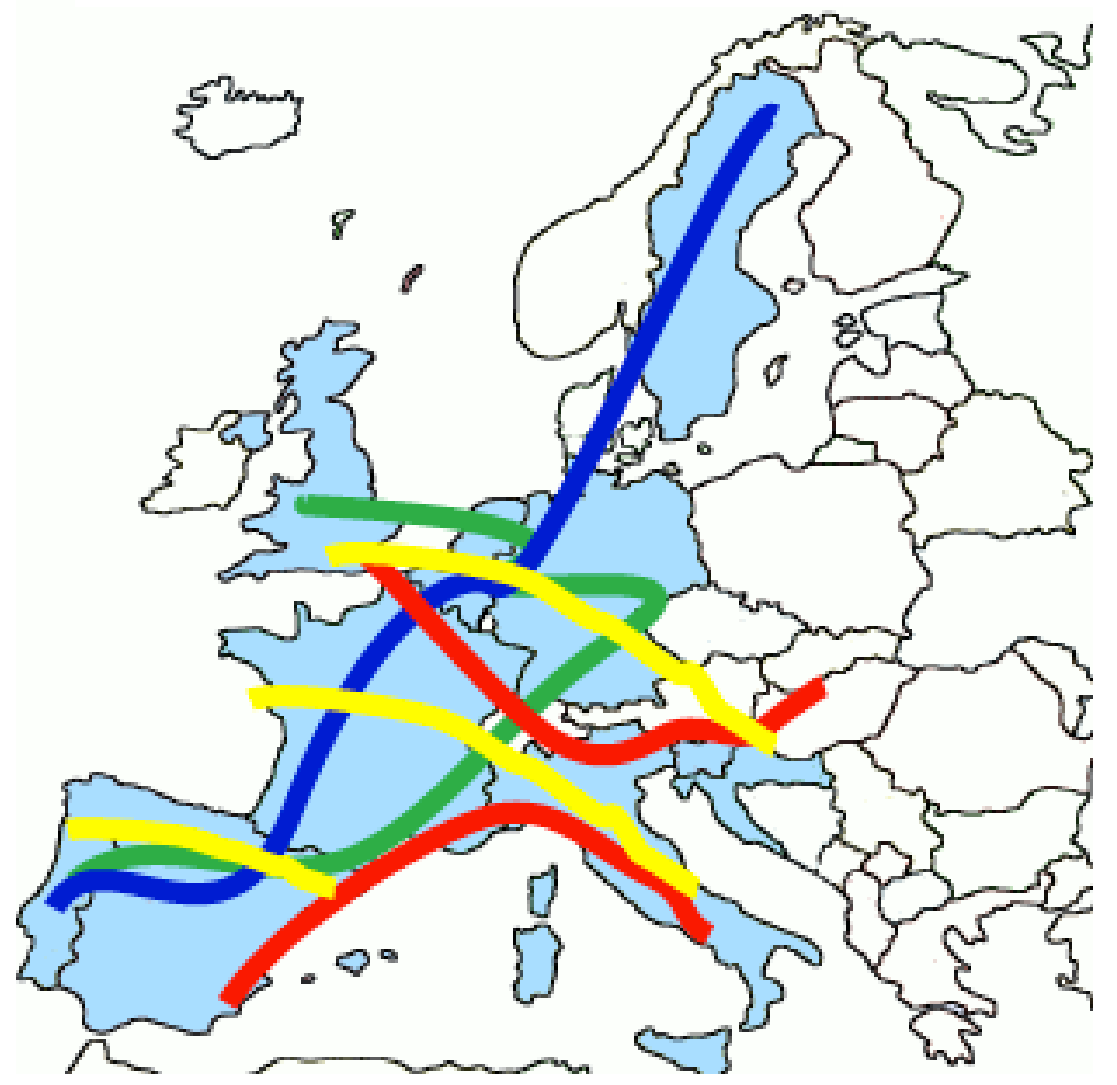

Source: LNG Blue Corridor Project

\subsection{Country review}

In addition to EU polices described above there are a range of specific country initiatives which are considered in this section.

It is not the intention of this study to provide an exhaustive list of developments and incentives regarding NGVs in Europe or indeed elsewhere. However it is helpful to highlight developments in one or two countries where Governments or other bodies have been particularly active in order to assess the effectiveness or otherwise of various initiatives.

\subsubsection{Germany}

The German government has set up the "Initiative for Natural-Gas-Based Mobility" in 2010 coordinated by DENA, the German Energy Agency, with a view to removing existing market constraints and increasing the market share of NGVs by 2020. DENA states that the share of methane in the transport fuel mix at the end of 2011 was $0.47 \%$. This is targeted to grow to $4 \%$ by 2020 with an increase in NGVs from 94,000 to some 1.4 million and a consequent 

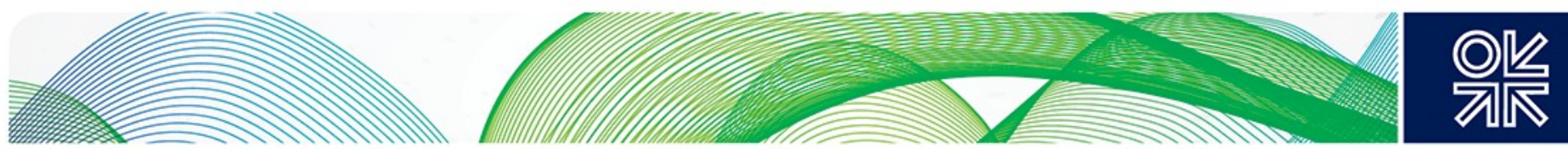

annual reduction of 1 million tonnes/year of $\mathrm{CO}_{2}$ emissions ${ }^{102}$. Biogas is also intended to play a major role in transportation primarily through a $20 \%$ blend with natural gas ${ }^{103}$

DENA claims that the strategy is already reaping some success with 4,300 NGV registrations in the first 6 months of 2013 - a four year high ${ }^{104}$.

German car manufacturers have started to increase their NGV offerings. For example Volkswagen has introduced a new Golf VII to join its Scirocco and eco up! NGV and Audi has launched the A3 TCNG and an A4 NGV will be introduced in 2014.

With over 900 CNG stations, clear Government targets and a number of new vehicles available, Germany will be an important bellwether regarding the success of an NGV strategy for passenger cars.

\subsubsection{Italy}

NGVs have a strong position in Italy, with 760,000 natural gas vehicles (over $75 \%$ of the NGVs in the EU) and 810 public refuelling stations (as of June 2011). Italy has more than 30 years experience of natural gas in transport initially as the result of a very active retrofit conversion industry in the 1970s and 1980s. A further boost for the sector came in the 1990s with a number of popular small and medium-sized cars becoming available as ex-factory CNG versions. ${ }^{105}$

The conversion programme has continued with the government making some $€ 24.8$ million available through incentives provided via specialised workshops and dealers. These incentives range from $€ 650$ to $€ 2,400 /$ vehicle depending on the type of vehicle ${ }^{106}$. Two challenges facing the sector are the scaling back of incentives since 2010 and the geographically uneven distribution of refuelling stations with a disproportionate number located in the north and/or away from motorways.

\subsubsection{Netherlands}

The NGV sector has been relatively undeveloped with LPG being the main alternative fuel for transport. This began to change in 2005 with the construction of CNG stations and there are now over 130 supplying 6,000 mainly public sector vehicles.

From July 2011 the Government has allocated US\$ 3.79 million in grants towards company cars that run on "green gas", biogas and higher blends of biofuels. More recently the Government and industry have agreed the Green Deal LNG which targets 50 inland barges, 50 sea going ships and 500 LNG trucks running on LNG by 2015. The initiative is also aiming

\footnotetext{
${ }^{102}$ See http://www.dena.de/en/projects/transport/initiative-for-natural-gas-based-mobility-cng-and-biomethane-asfuels.html

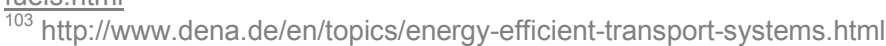

104 http://www.erdgasmobilitaet.info/service-und-aktuelles/aktuelles-undpresse/meldung/datum/2013/07/18/neuzulassungen-fuer-erdgasfahrzeuge-auf-4-jahres-hoch-neuer-aufsichtsrat-vonerdgas-mobil-bekraefti.html

${ }^{105}$ EEGFTF (2011b)

${ }^{106}$ See www.ecogas.it
} 

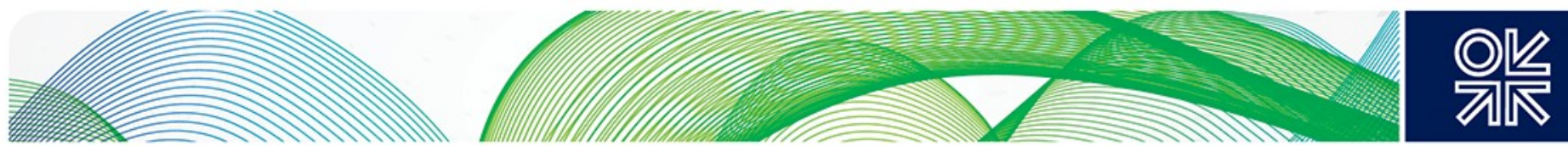

to facilitate the development of a NW European platform for LNG-based transportation along the Rhine corridor through Germany to Switzerland ${ }^{107}$.

\subsubsection{France}

France has had an active NGV sector since 1995 . Presently $10 \%$ of buses and $13 \%$ of refuse trucks $(2,400$ and 800 respectively) are fuelled by CNG and there are over 10,000 cars and LDVs though most of these are fleets. There are 260 , mainly private, refuelling stations.

The specific incentive for buying NGVs was removed in January 2011 as the Government declared it had achieved its goal of encouraging buyers to opt for low $\mathrm{CO}_{2}$ models, though a smaller incentive remains for all low emission vehicles. There are also concerns that the zero tax rating for natural gas as a fuel for vehicles will be removed in 2014. The Government is also planning to introduce an "ecotax" on all HDV movements though the date of introduction and how it will apply to vehicles using natural gas is not yet clear ${ }^{108}$.

GDF SUEZ is actively promoting LNG for HDVs and the off-grid supply of LNG to industrial consumers is also stimulating demand in the transport sector ${ }^{109}$. In the marine sector Brittany Ferries plans to introduce an LNG-fuelled vessels in $2017^{110}$.

\subsubsection{UK}

The main focus in the UK is on gas-powered heavy vehicles - both CNG and LNG. The availability of LNG from the Avonmouth peak shaving storage site has formed the basis for a number of pilot schemes. Funding has in part been provided by the Low Carbon Vehicles Innovation Platform as part of a low carbon truck demonstration trial ${ }^{111}$. Table 10 summarises some of the projects. This suggests that whilst a number of large operators have engaged in NGV pilots these vehicles still represent a relatively small proportion of their total fleets though in some cases - for example DHL - further expansion of the NGV fleet is underway.

\footnotetext{
${ }^{107}$ http://www.nationaallngplatform.nl/

08 http://about-france.com/hgv.htm

109 Presentation by C Hubert at LNG 17, Houston, April 2013

${ }^{110} \mathrm{http}: / / \mathrm{www} \cdot \mathrm{marinelog} \cdot \mathrm{com} / \mathrm{index}$.php?option=com k2\&view=item\&id=6032:brittany-ferries-set-to-order-Ing-fueledferry\&ltemid $=230$

https://www.innovateuk.org/transport\#platform
} 

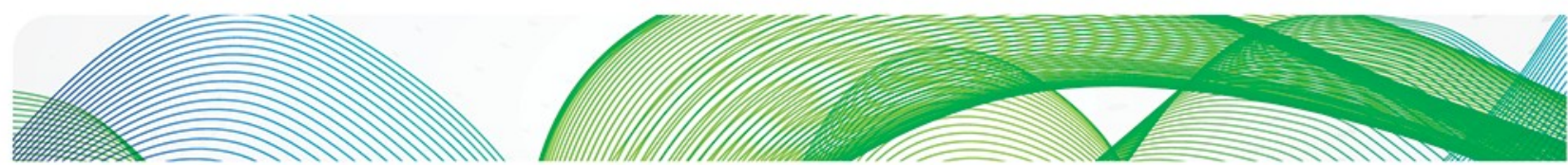

Table 10: Sample UK HDV pilots using natural gas

\begin{tabular}{|c|c|c|c|c|}
\hline Company & $\begin{array}{l}\text { Number of } \\
\text { vehicles }\end{array}$ & Total fleet & Description & Start date \\
\hline Tesco $^{112}$ & 35 & 2,000 & $\begin{array}{l}\text { BioLNG/LNG }(15 / 85) \text { supplied by } \\
\text { GasRec to Daventry depot }\end{array}$ & May 2013 \\
\hline $\begin{array}{l}\text { Muller } \\
\text { Wiseman }\end{array}$ & $\begin{array}{l}21 \\
\text { increased } \\
\text { to } 40\end{array}$ & 1,000 & $\begin{array}{l}\text { Dual-fuelled vehicles. 55\% LNG. } 2 \\
\text { LNG stations operated by Chive }\end{array}$ & 2007 \\
\hline Stobart & 5 inc to 25 & 2,350 & Dual-fuelled vehicles. 65-70\% LNG & 2010 \\
\hline John Lewis & 8 & $\begin{array}{l}2,700(570 \\
\text { tractors })\end{array}$ & $\begin{array}{l}\text { Dual-fuelled vehicles. } 35-55 \% \text { CNG } \\
\text { linked to biomethane plant }\end{array}$ & 2012 \\
\hline $\mathrm{DHL}^{113}$ & 101 & 7,500 & $\begin{array}{l}\text { Dual-fuelled LNG vehicles refuelled } \\
\text { by BOC at DHL's Bawtry deport }\end{array}$ & 2011 \\
\hline
\end{tabular}

Source: Company websites and presentations

The Tesco liquefied biomethane (LBM) pilot is an interesting example of biogas based on a landfill site in Surrey. The plant was commissioned by GasRec in June 2008 with capacity to produce approximately 4,300 tonnes of liquid biomethane per annum (equivalent to 5.2 million litres of diesel) $)^{114}$. The BLNG - which is a mixture of LBM (15 to $25 \%$ ) and LNG supplied from National Grid's Avonmouth site - is supplied to GasRec's filling stations (of which there are eight) or direct to clients' sites such as Coca-Cola's Enfield depot. According to Brightman et al (2013) this gas is presently priced between conventional LNG and diesel. The present UK incentive regime favours the use of untreated biogas for the production of electricity rather than treating it for grid injection or using it as a vehicle fuel.

In the car sector the focus of government is primarily on decarbonising the sector via electric vehicles or hybrids (Batterbee and Lidstone, 2013). Grants are available towards the costs of a BEV and a number of charging points have been installed though the rate of take-up to date has been below expectations with $75 \%$ of charging points in London remaining unused ${ }^{115}$.

\subsubsection{Sweden}

According to the Swedish Gas association ${ }^{116}$ there were approximately 44,000 gas vehicles at the end of 2012 and 138 public and 57 private filling stations. The country has a relatively large proportion of gas fuelled buses (around 13.7\% compared to an EU average of $1.8 \%$ ) and accounts for $38 \%$ of road vehicle consumption of methane in Sweden.

Clean Air Power is engaged in a long term project with Volvo to develop dual-fuelled buses and the Swedish Energy Agency has contributed US $\$ 3.4$ million to the scheme ${ }^{117}$. Separately the Goteborg region is trialling long distance biomethane trucks and buses (BiMe) with a US\$3.4 million grant from the Swedish Energy Agency. NGV car usage is also encouraged through lower tax charges on company cars and reduced road tax.

\footnotetext{
$112 \mathrm{http} / / /$ www.e2bpulse.com/Articles/353338/35_Tesco_trucks_to_run_on_Gasrec_s_Bio_LNG.aspx

113 http://www.shdlogistics.com/news/view/dhl-runs-dual-fuel-vehicles-in-uk

${ }^{114}$ See http://gasrec.co.uk/

115 See The Times, 14 December,2013, "Millions wasted on charging points that fail to spark"

${ }^{116}$ http://www.energigas.se/Energigaser/Fordonsgas/Statistik

117 IGU (2012)
} 

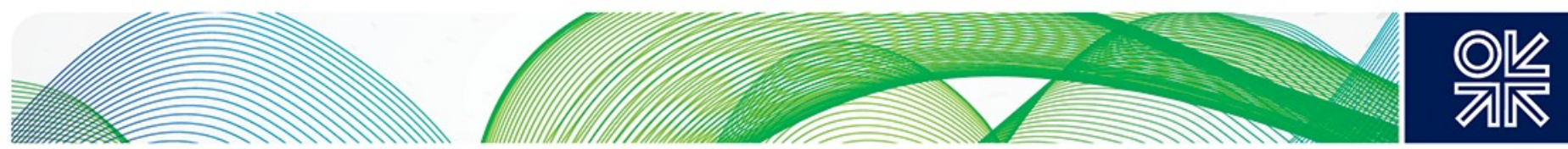

The LNG sector is also expanding; there are five LNG stations and two under construction. There are three marine refuelling facilities and four are planned. This includes Nynashamn near Stockholm which has a capacity of $20,000 \mathrm{~m}^{3}$ and can receive LNG carriers with a capacity of $7,000 \mathrm{~m}^{3}$.

Sweden is a strong advocate of biomethane and uses it as an off-grid source of gas as well as being purified and injected into the grid. There are 64 biomethane refuelling station (out of 130 public CNG refuelling stations) and around 60 upgrading units ${ }^{118}$ and biomethane accounted for around $60 \%$ of gas sold for road vehicle use ${ }^{119}$. Future truck demand is put at 2.5 TWh by 2020 and 10 TWh by 2030 whilst LNG demand for ships in the Baltic region is forecast to reach 60 TWh by 2020 and 96 TWh by $2030^{120}$ (4.2. and 7 million tonnes respectively).

\subsubsection{Norway}

Seen by many as a pioneer in LNG shipping, Norway has made $\$ 75$ million available under the Norwegian NOx Fund to subsidise LNG shipping retrofits and new builds and has sponsored a national LNG bunkering network. LNG ships are present in most sectors in the country and 49 vessels have been converted to LNG or built new ${ }^{121}$.

\subsubsection{Spain}

The large number of LNG regasification terminals and the significant movement of LNG to provide gas for remote networks (there were over 45,000 truck loadings of LNG in 2012 ${ }^{122}$ ) has provided a basis for LNG-based transportation in Spain. Utilising European Commission TEN-T funding (under the GARneT programme) Gas Natural Fenosa plans to build seven LNG service stations (four fixed and three mobile) to identify the technologies with the greatest potential for broader European rollout ${ }^{123}$.

A total of 26 cities have CNG supply stations, including Madrid, Barcelona, Burgos, Salamanca, Seville and Valencia. The city of Madrid has its entire fleet of 670 refuse trucks and 790 of its 2000 buses running on $\mathrm{CNG}^{124}$.

\subsubsection{Other Europe}

In Poland recently there has been significant activity in the bus sector with a joint venture between Gazprom and Solbus resulting in a number of cities using LNG-fuelled buses in part of their fleets ${ }^{125}$

\footnotetext{
${ }^{18}$ GasHighWay (2012)

${ }^{19}$ http://www.ndptl.org/c/document_library/get_file?folderld=19620\&name=DLFE-

1547.pdfhttp://webbshop.cm.se/System/TemplateView.aspx?p=Energimyndigheten\&view=default\&id=08a3e86acdea 49d0a84e99be293e379a

${ }^{120}$ Swedegas presentation at Natural Gas Vehicle Conference Amsterdam(25-26th Nov 2013)

${ }^{121}$ https://www.tekna.no/ikbViewer/Content/874902/10_Geir\%20H\%F8iby.pdf

122 GLE (2013)

${ }_{123}^{123}$ http://www.ngvglobal.com/gas-natural-fenosa-reports-on-ec-garnet-project-for-Ing-refuelling-infrastructure-1130

124 IGU 2012, p85 and operator information

${ }^{125}$ Presentation by Solbus at Natural Gas Vehicle Conference Amsterdam(25-26th Nov 2013)
} 

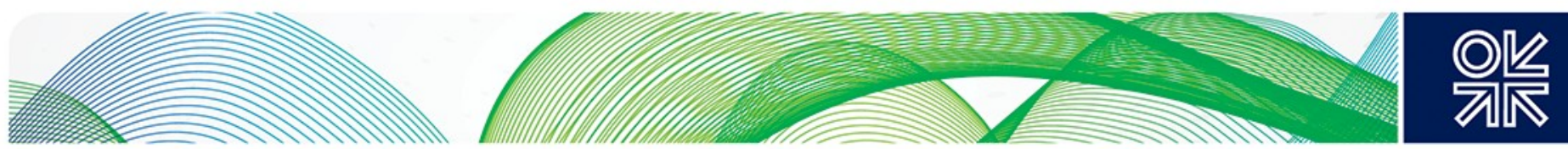

According to EEGFTF ${ }^{126}$, there is a quota of $10 \%$ biomethane in natural gas for vehicle fuel in Switzerland that has resulted in the gas industry investing in injection and fuelling infrastructure to achieve this.

In Austria OMV and the Austrian Minister for Environment signed an agreement in June 2006 which has resulted in over 175 public CNG stations being constructed by June 2013 . The impact on the number of vehicles has been limited however as, according to the IGU the incentives for NGV ownership are limited ${ }^{127}$.

\subsubsection{Russia}

With plentiful supplies of gas, relatively low growth in traditional markets and aspirations to develop a thriving automotive sector, Russia is an obvious location for NGVs. It also benefits from a low gas price though diesel and gasoline prices are also lower than in the EU. At present around $0.4 \mathrm{bcm}$ of gas is sold annually in the form of CNG. There are about 250 gas filling stations in Russia, of which Gazprom Neft operates $85 \%$.

The Government announced a renewed strategy aimed at boosting natural gas use in transportation in May 2013. The strategy has the following targets ${ }^{128}$ :

- CNG vehicles to achieve market shares of $50 \%$ in public transport, $30 \%$ in trucks and $20 \%$ in agriculture by 2020

- An increase in CNG vehicles to 2.5 million (from 90,000 in 2011) and filling stations to $3,500(250)$ by 2030

- To position Gazprom in the European NGV market which was expected to reach 45 bcm/year by 2030

Both Rosneft ${ }^{129}$ and Gazprom ${ }^{130}$ have announced plans to develop CNG refuelling infrastructure and have formed partnerships with vehicle manufacturers. The Russian market, however, faces many of the challenges faced by the European markets for NGVs and the relative low cost of gasoline and diesel is another potential barrier.

\subsubsection{Ukraine}

According to NGVA statistics there are 388,000 natural gas vehicles in Ukraine accounting for $35 \%$ of the total vehicle population - of this total 233,000 are buses (including minibuses) and 136,000 trucks. Some 350,000 of this vehicle population can also run on gasoline.

CNG demand grew strongly in 2007 when it was $65 \%$ cheaper than petrol and car owners were converting their vehicles at a rapid rate. However the combination of a four-fold increase in CNG prices (driven by new gas contracts with Russia) restrictions on new connections and the economic crisis led to a fall in demand and a sharp decline in the rate of growth of new refuelling stations.

\footnotetext{
${ }^{126}$ EEGFTF (2011b), p 32

${ }^{127}$ IGU (2012) , p 21

${ }^{128}$ Demin (2013)

${ }^{129} \mathrm{http} / / /$ www.rosneft.com/news/pressrelease/140520132.html

${ }^{130}$ http://www.gazprom.com/press/news/2013/february/article156754/
} 

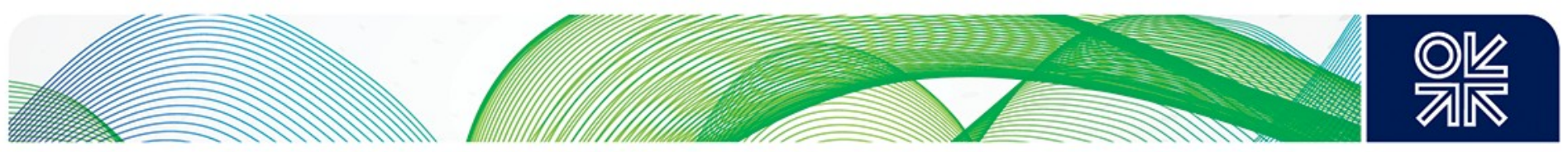

By 2012 the price differential between CNG and LPG had disappeared and the discount of CNG to gasoline had declined to below $40 \%$. The number of refuelling stations has reached a plateau though it is reported that many are failing to break-even due to the depressed demand (down from 30 million cubic metres $(\mathrm{mcm}) /$ month in early 2011 to $17 \mathrm{mcm} / \mathrm{month}$ in January 2013) and the limited number of station closures could accelerate ${ }^{131}$. So whilst Ukraine is the second largest NGV country in Europe in terms of vehicle numbers its present position in terms of gas consumption is low. This situation may change as a result of the intergovernmental agreement with Russia that has led to a reduction of $30 \%$ in prices paid for imports under the contract with Gazprom. As a result of this on 30 December 2013 the National Commission for Energy Regulation reduced regulated prices by between $10 \%$ and $29 \%$ whilst free market prices are expected to fall by $10-15 \%$ all of which should make gas in transportation much more competitive. However the Ukraine-Russia agreement is subject to change due to political events and the price reductions have to be agreed on a quarterly basis. Any increase in gas demand for transportation could therefore be relatively short lived. ${ }^{132}$

\subsection{Summary of the present status of NG in transportation in Europe}

This chapter has examined the present status of NGVs and the role of national governments and the EU in fostering the growth in gas usage in transportation. NGV ownership worldwide is growing strongly though the rate of growth is much faster in Latin America and Asia Pacific than in Europe.

Policy drivers from the European Commission are focussed on reducing vehicle emissions and dependence on imported oil and there are a range of policies and initiatives covering areas such as fuel quality, engine design, alternative fuels infrastructure and pilot projects aimed at achieving these objectives. Whilst there is generally strong EU support for NGVs there is also the recognition that there are other low carbon transport option. Furthermore the nature of the issue means that initiatives arise from the energy, climate and mobility and transport departments and there is inevitably a degree of overlap and uncertainty regarding long-term objectives.

Looking at individual countries the picture across Europe is far from uniform. Some countries, such as Italy and Germany, are continuing to build on a legacy of CNG usage whilst others appear to be putting most emphasis on the potential for LNG-fuelled transport as in the case of Norway, Spain and the UK. The presence of existing LNG capacity would appear to be an important factor in stimulating the market in some countries. Overall whilst activity levels could be said to be increasing it is still far from clear how the market in Europe might ultimately develop.

The next section seeks to answer this question and looks at how the NGV markets might evolve by considering the position of the key stakeholders in the main market sectors. 

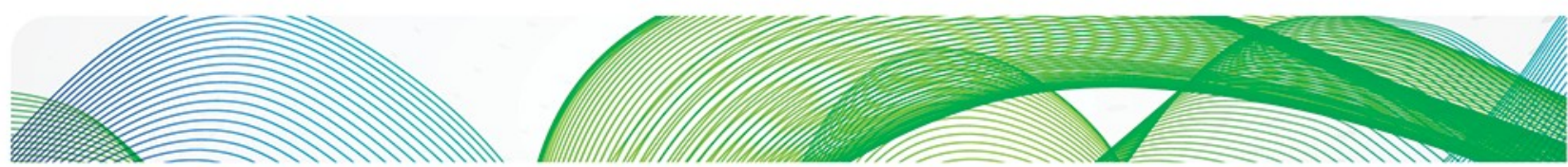

\section{Outlook for future usage of natural gas in transport}

It has already been noted that natural gas as a fuel is not a new mode of transport. It is rather an alternative to existing fuels in existing transport modes. In other words if natural gas is to grow in the transportation sector it has to be market led and adapt to the needs of each segment of the market. It is therefore necessary to analyse the prospects for natural gas according to existing market segments and frameworks.

The decision to switch to natural gas as a fuel for vehicle use is driven by a range of internal and external factors that will vary with market segment and vehicle type. This chapter analyses the key factors involved in order to assess what this might mean in terms of future purchases of gas-fuelled vehicles and the impact this could have on gas demand. The key factors governing the choice of vehicle and fuel are examined for each market sector in turn, though before these are considered in detail the overall analytical framework is described.

\subsection{The analytical framework}

There are three dimensions to the analytical framework:

- Segmenting the market into key categories - namely:

- Cars and light commercial vehicles - collectively referred to as light duty vehicles (LDVs),

- Buses,

- Large commercial and freight vehicles - collectively referred to as heavy duty vehicles (HDVs)

- Waterborne transport by sea and inland waterway

- Describing the key factors that drive the vehicle purchase decision for each segment

- Projecting the possible future levels of demand for NGVs and gas for transportation in Europe.

The last two dimensions are described in more detail in the following sections.

\subsubsection{Factors driving the purchase decision}

A range of external influences and the decisions of key stakeholders will shape the key factors driving a move towards NGVs.

The main influences that can be classed as predominantly external to the NGV environment are:

- Economic background - this includes factors such as rates of economic growth and personal disposable income;

- Levels of transport demand in terms of both usage and the rate of vehicle turnover;

- Technology developments impacting on vehicular transport such as innovative electric vehicle solutions;

- Tax rates or rebates applied to alternative vehicle fuels;

- Developments in global energy markets with particular reference to inter-fuel pricing, carbon pricing and LNG availability. 

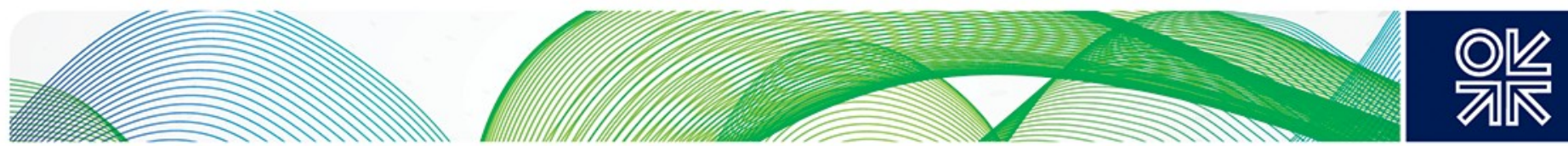

The other set of factors relates to the role of key stakeholders in either making or influencing the purchase decision. In broad terms it is possible to identify four groups of stakeholders:

- Vehicle or vessel owners/operators - these may include the customer of the service in the case of, say, large retailers who outsource their transport and logistics requirements;

- Manufacturers (OEMs) and distributors of vehicles and vessels - this could also include maintenance service providers;

- Infrastructure providers - i.e. owners/operators of the refuelling network;

- Government and other policy makers (e.g. EU, international standards organisations, national agencies etc).

A representation of both factors and key stakeholders is shown in Figure 15. Clearly some stakeholders will have a role in shaping or influencing the external factors. For example government policy will have an impact on the overall economic environment whilst manufacturers will be closely involved in emerging technologies.

Figure 15: Key external factors and stakeholders

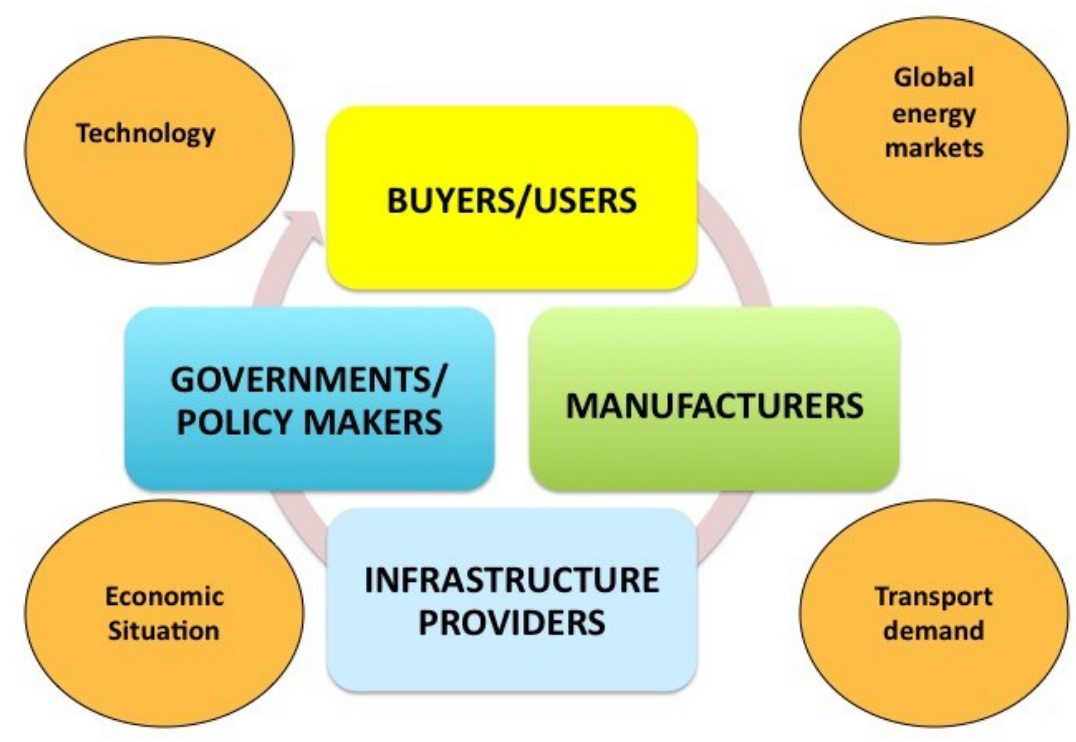

Source: Author based on Batterbee \& Lidstone (2013)

The stakeholder positions for each market segment and how these might shape their actions for each transport mode are considered below.

\subsubsection{Determining the potential for growth}

One of the main objectives of the research is to determine likely levels of penetration of natural gas in the various sectors. This study has identified a number of forecasts and these are described in the following sections. In addition the author has taken a simplified approach in order to develop some basic projections (not forecasts) of natural gas usage based on a range of levels of market penetration in each of the sectors identified above. 

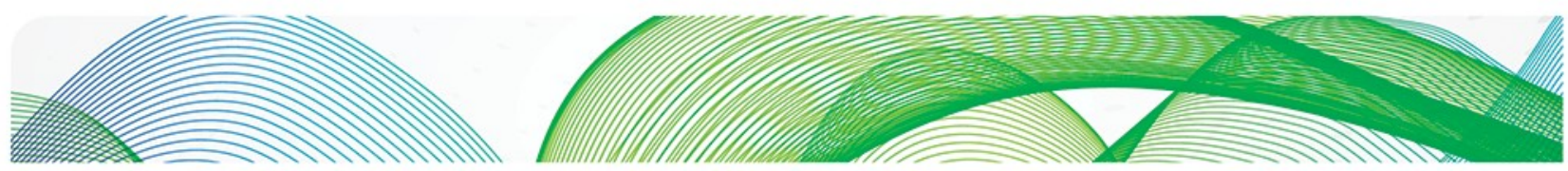
$\frac{O K}{7 \mathbb{R}}$

The following broad assumptions will feed into this process:

- Price differentials with competing fuels are assumed to remain at broadly the same level in favour of natural gas and will continue to comprise both commodity and fiscal advantages.

- In Europe the greatest potential for natural gas is likely to be in the heavy goods vehicle and marine/waterway sectors and so these sectors are likely to achieve higher levels of ultimate penetration than the car/LCV sector.

- Virtually all switching to natural gas road vehicles will take place at the point of normal vehicle replacement - i.e. the retrofitting market is unlikely to be very significant. This means that the number of new registrations per annum in each sector is a key variable as is the predicted level of market penetration. This may also be true in the marine and waterways sector though it is understood that retrofitting is more viable and so a broader brush approach has been adopted for this sector.

- Annual consumption of fuel per vehicle will decline in line with assumed improvements in engine efficiency but will otherwise remain unchanged from the numbers quoted by NGVA, adapted where appropriate.

The starting point for the projections is based on NGVA's assumptions for average distance travelled for each vehicle type which are used to calculate the theoretical consumption of methane gas (i.e. natural gas plus biomethane) used as a vehicle fuel. Theoretical consumption is calculated by NGVA by multiplying the vehicle population by assumed total annual consumption of $2,160 \mathrm{~m}^{3}$ for cars and $36,000 \mathrm{~m}^{3}$ for buses and trucks (note the truck estimate is an average that may understate gas consumption by HDVs - this is discussed below). The latest estimates of current ${ }^{133}$ annual consumption by vehicle type for the $\mathrm{EU}$ is shown in Table 11. It should be noted that Eurogas (2013b) put the total inland consumption of natural gas in the transport sector at around $1.8 \mathrm{bcm} / y e a r$ - this is likely to be an underestimate as not all transport uses will be captured so the NGVA estimate of $2.78 \mathrm{bcm}$ could be viewed as reasonable.

In Table 11 the figures for 'other Europe' have been excluded as the calculations are distorted by the very high population of NGV buses and trucks in Ukraine which gives a theoretical consumption in excess of $13 \mathrm{bcma}$, as section 4.3 .11 notes the reported annualised consumption in Ukraine is between 200 and 350 million $\mathrm{m}^{3}$. The discrepancy is likely to arise from the fact that most of the NGVs are dual-fuelled vehicles.

Table 11: Current theoretical annual methane consumption by vehicles in the EU and EFTA

\begin{tabular}{|c|c|}
\hline Category & $\begin{array}{c}\text { EU and EFTA } \\
(\mathrm{bcm})\end{array}$ \\
\hline Cars & 2.11 \\
\hline Buses & 0.47 \\
\hline Trucks & 0.18 \\
\hline Total & 2.78 \\
\hline
\end{tabular}

Source: NGVA Europe and the GVR

\footnotetext{
${ }^{133}$ The NGVA statistics are the latest available from each country so they apply to different points in time - most countries' data are either 2012 or 2013.
} 

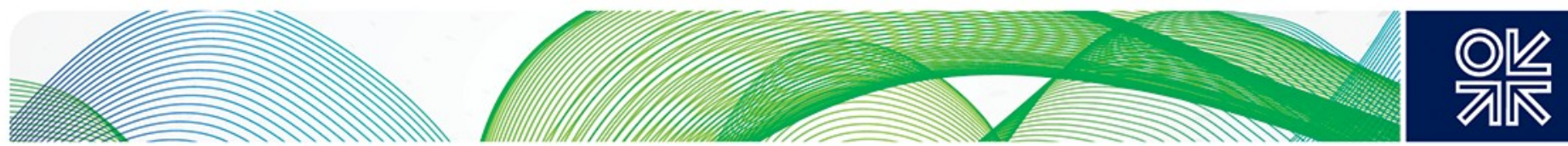

The study has developed projections derived from the above assumptions to show market shares and gas consumption levels in 2025 and 2030. How these shares and volumes build up year by year is not presented, though the actual position will depend on a variety of factors.

Most research suggests that new technologies are adapted in line with the product diffusion curve. An example of this is provided by Vyas et al ${ }^{134}$ who note that the build-up of market share of a new technology is limited in the early stages because very few buyers adopt it these have been variously referred to as "pioneers", "early adopters" and "zealous optimists" ${ }^{\prime 35}$. The rate of penetration increases when other buyers learn from the experience of the early buyers and gain assurance that any teething troubles have been resolved. Eventually the rate of market penetration starts to tail-off when most buyers that would benefit from the technology have adopted it - or new options start to become available. An "S" shaped curve typically represents the pattern described and an example is shown in Figure 16.

Figure 16: Example $S$ curve showing predicted penetration profile for aerodynamic improving technologies for trucks

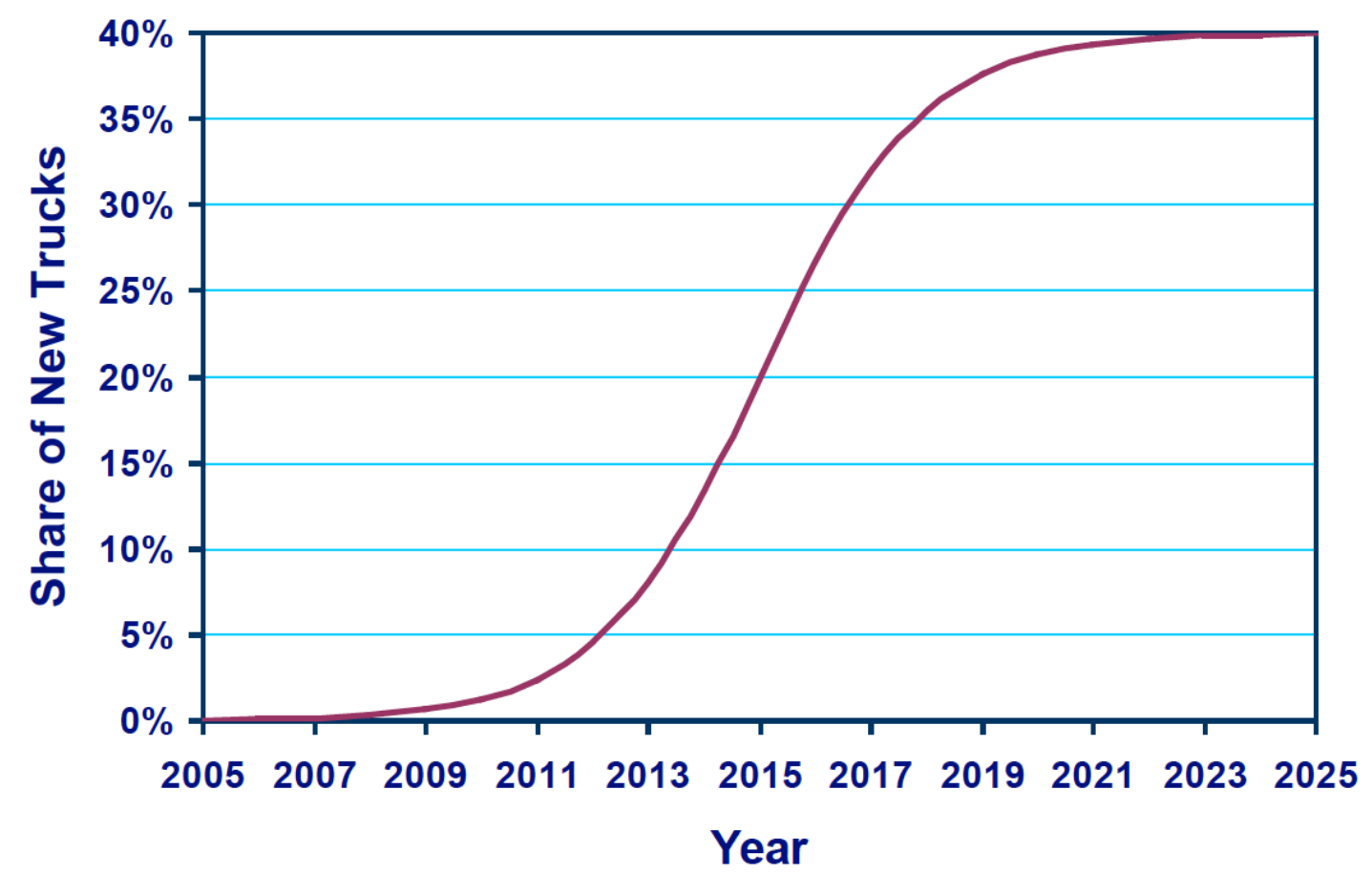

Source Vyas et al (2002)

This pattern of market penetration seems particularly likely in the case of natural gas as it also reflects the potential way in which momentum would build as more vehicle types become available and the refuelling infrastructure is more extensive. The key questions are of course what will the ultimate penetration be and over what timescale will it be achieved? 


\subsection{Cars and light commercial vehicles (LDVs)}

NGVA statistics for the number of natural gas vehicles do not distinguish between passenger cars and light duty commercial vehicles. The latest position for Europe including Russia and Turkey is shown in Table 12. This table includes CNG refuelling stations.

Table 12: Natural gas light duty vehicles and CNG refuelling stations in Europe, 2011-12

\begin{tabular}{|c|c|c|c|c|c|c|}
\hline & \multirow{2}{*}{$\begin{array}{l}\text { Total cars } \\
\text { and LCVs } \\
\text { (million) }\end{array}$} & \multirow{2}{*}{$\begin{array}{l}\text { NGVs } \\
(' 000)\end{array}$} & \multirow{2}{*}{$\begin{array}{l}\text { NGVs } \\
(\%)\end{array}$} & \multicolumn{3}{|c|}{ Number of CNG refuelling stations } \\
\hline & & & & Public & Private & Planned \\
\hline EU & 260.1 & $1,079.7$ & 0.42 & 2,482 & 487 & 214 \\
\hline Russia & 29.4 & 65.0 & 0.22 & 211 & 41 & 15 \\
\hline $\begin{array}{l}\text { Other } \\
\text { Europe* }\end{array}$ & 25.1 & 233.3 & 0.92 & 767 & 203 & 56 \\
\hline Total & 314.6 & $1,378.0$ & 0.43 & 3460 & 731 & 285 \\
\hline
\end{tabular}

Source: NGVA Europe and the GVR

*Includes Turkey

Only two countries in the EU have significant shares of NGVs in this sector: Italy $(2.1 \%)$ and Bulgaria (2\%). Germany and Sweden also have a relatively large absolute number of NGVs 94.7 thousand $(0.2 \%$ share) and 41.8 thousand $(0.9 \%)$ respectively. The relatively high percentage share for 'other Europe' is due to the large number of NGVs recorded in Armenia and Ukraine. As noted above it is understood most of these vehicles are dual-fuelled.

The LDV NGV sector has exhibited rapid growth in recent years and the vehicle parc is some $57 \%$ higher in 2012 than in 2008. Though as Figure 13 shows this growth rate is low compared to regions such as Asia Pacific and Latin America.

Figure 17 shows the key external factors and stakeholder map for cars and light vans. Technology is a particularly important factor as a number of alternative fuel sources are under active development - these include electric and hydrogen vehicles. How these developments interact with government policies is considered below. 

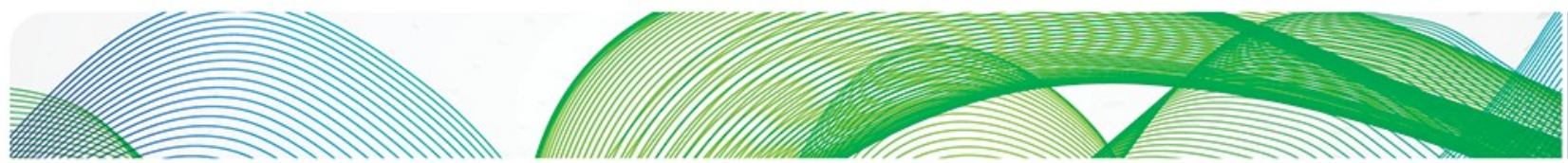

Figure 17: Key external factors and stakeholder map for cars and light vans

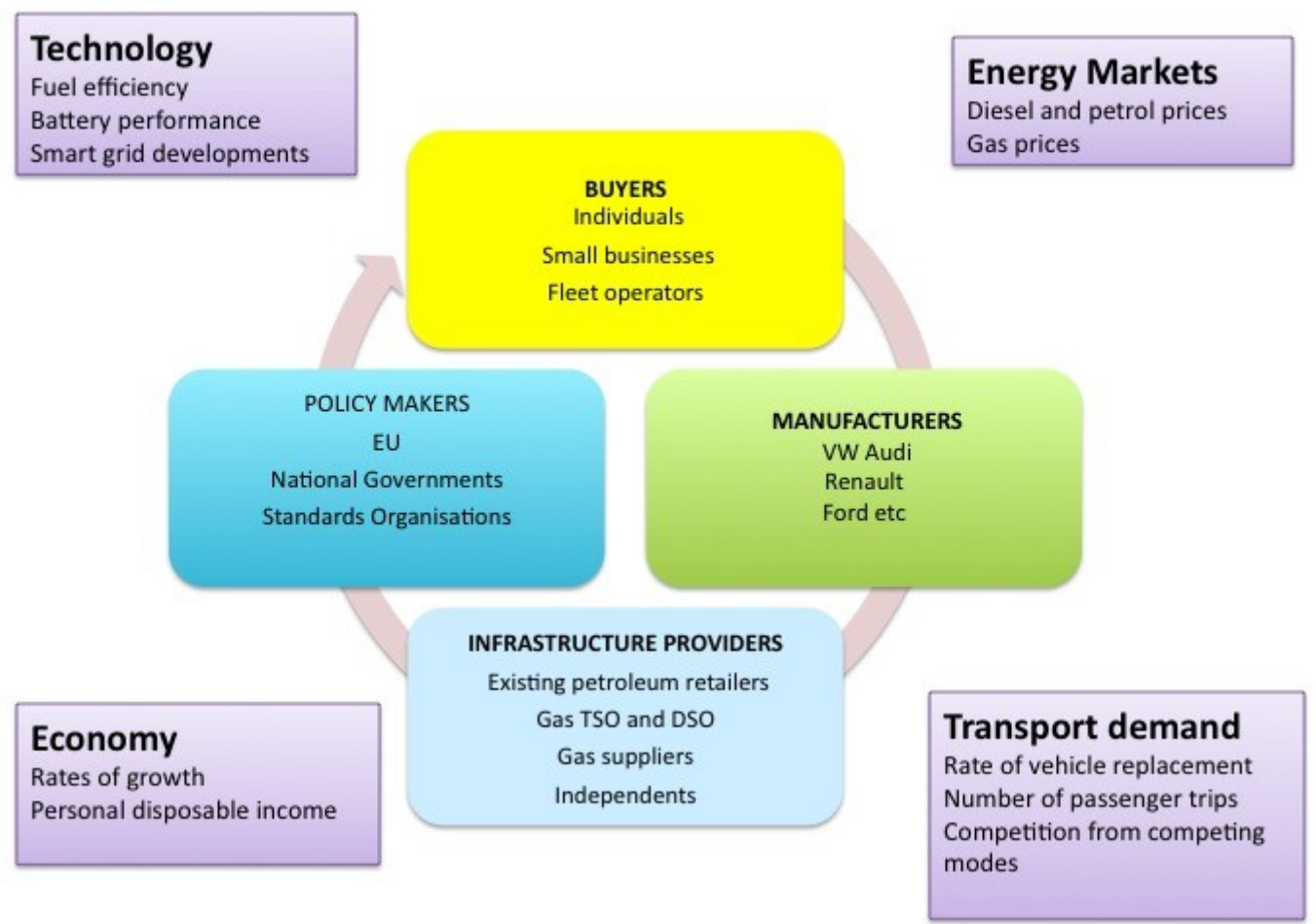

Source: Author based on Batterbee \&Lidstone (2013)

\subsubsection{Buyers}

The car purchase decision is either taken by individual consumers or, for large fleets of vehicles, by a professional procurement entity. Light commercial vehicles can similarly be procured by sole traders or large organisations.

For personal car buyers it has been pointed out that whilst cars are used frequently they are rarely bought and the purchase decision is a complicated, high involvement process involving a series of trade-offs between so-called purchase parameters such as price, fuel efficiency etc $^{136}$.

Research in the UK suggests that the three key parameters are fuel efficiency/running costs, size/practicality and vehicle price. Fuel efficiency is important from both a financial and an environmental perspective though environmental factors per se do not appear to play a major role in influencing the purchase decision and buyers typically viewed lower emissions as a "bonus"137.

This conclusion is supported by research into the reasons consumers buy hybrid electric cars. These purchases involved a significant premium above the conventional alternative and the research suggests that the key factors were social image-related (e.g. makes me look good, fit with peer group) rather than factors such as purchase price and running costs. These latter were the criteria used by buyers of conventional vehicles ${ }^{138}$. Others have suggested that

\footnotetext{
${ }^{136}$ Chua et al (2010)

${ }^{137}$ Lane \& Banks (2010)

${ }^{138}$ Chua et al (2010)
} 

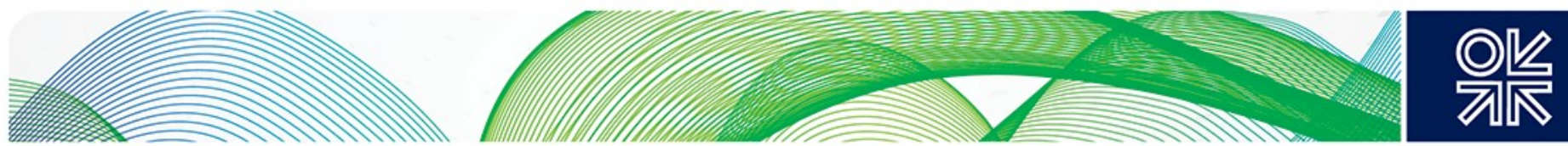

those who care most about the environment are likely to abstain from or severely restrict their driving. $^{139}$

The foregoing provides further confirmation that the adoption of new vehicle types such as hybrids should be seen in the form of a diffusion of the innovations model (or the product diffusion curve shown in Figure 16). As noted above this approach groups consumers according to how quickly they adopt a new product - innovators, early adopters, early majority and so on - and suggests that progress of innovations is linked to the pace of adoption by different key groups.

This study has not been able to identify research that indicates whether the product diffusion curve approach is appropriate for gas-powered vehicles in the consumer sector. However, it could be argued that the financial attractions of running a CNG powered car may attract a different group of buyers from those who are driven by environmental motives and that the latter may opt for lower carbon alternatives.

Figure 18 shows a ranking of different factors behind the car purchase decision. Whilst fuel costs could be taken as representing some environmental advantage, direct environmental factors such as lower emissions or tax band are ranked relatively low.

Figure 18: Factors initiating the decision to buy current car

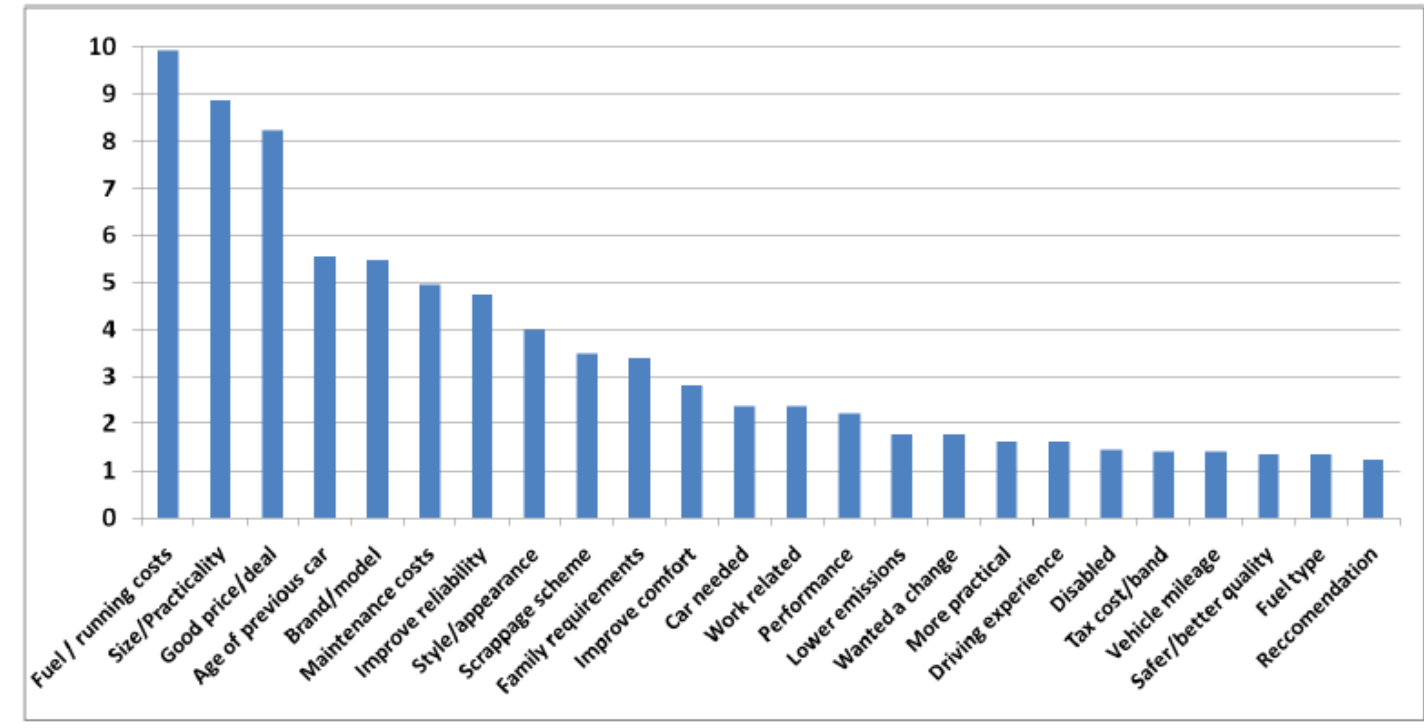

Source: Low carbon vehicle partnership, Car Buyer Survey, Lane \& Banks (2010)

An important sector in the car-buying group are fleet purchasers (company cars). In the UK, for example, of the 2.04 million new registrations in 20121.11 million were fleet or business purchases $^{140}$. Research suggests that this sector is more likely to take account of environmental factors though running costs, safety and fuel costs all rank higher ${ }^{141}$.

A simplified break-even analysis has been undertaken using the consumption figures in Table 15 and the following assumptions which are based on Germany:

\footnotetext{
${ }^{139}$ Heffner et al (2005)

${ }^{140}$ SMMT (2013)

${ }^{141}$ GE Capital (2011)
} 

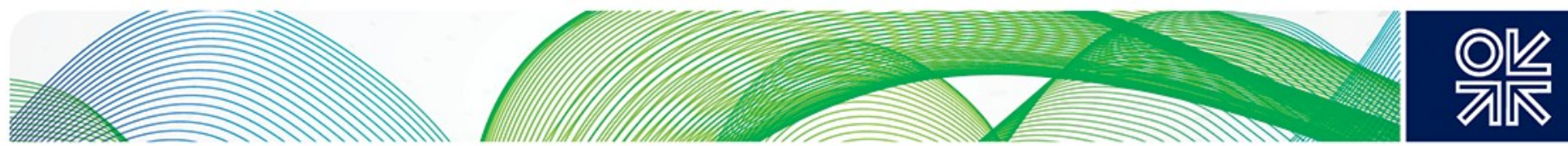

- Fuel cost of $€ 1.12 / \mathrm{kg}$ for CNG and $€ 1.41 /$ litre for diesel (equivalent to $\$ 30.7 / \mathrm{mmbtu}$ and $\$ 56.5 / \mathrm{mmbtu}$ respectively)

- Vehicle costs as shown in Table 14

- Annual usage of between 10,000 and 40,000 kilometres

Table 13: Breakeven analysis for CNG v diesel car

\begin{tabular}{|c|c|c|}
\hline Annual usage (km) & \multicolumn{2}{|c|}{ Undiscounted payback (years) } \\
\cline { 2 - 3 } & Mercedes B 200 & VW Golf \\
\hline 10,000 & 6.1 & $>10$ \\
\hline 20,000 & 3.0 & 6.7 \\
\hline 30,000 & 2.0 & 4.5 \\
\hline 40,000 & 1.5 & 3.4 \\
\hline
\end{tabular}

Source: Author's analysis

As Table 13 shows, a vehicle would have to have an annual usage in excess of $20,000 \mathrm{~km}$ in order to achieve a payback within 3 years in the case of a Mercedes CNG car and over $40,000 \mathrm{~km}$ for a VW version. The lower payback for the Mercedes option is primarily due to the relatively higher cost per kilometre for the equivalent diesel option (see Table 14).

\subsubsection{Manufacturers}

Automotive manufacturers by and large operate on a global basis using common platforms with a range of engine and body variations. The major European manufacturers who presently offer NGV variants include Fiat, Opel (part of GM), VW Audi and Mercedes. Table 14 shows a comparison between the standard and NGV version for two selected vehicles available in Germany.

Table 14: CNG and diesel comparison between selected cars

\begin{tabular}{|l|l|l|l|l|}
\hline Feature & \multicolumn{2}{|l|}{ Mercedes B 200 } & \multicolumn{2}{l|}{ VW Golf VII } \\
\hline Fuel & $\begin{array}{l}\text { CNG } \\
\text { "NGD" }\end{array}$ & Diesel & $\begin{array}{l}\text { CNG 1.4 } \\
\text { Bi-fuel }\end{array}$ & $\begin{array}{l}\text { Diesel } \\
\text { TDI 1.6 }\end{array}$ \\
\hline $\begin{array}{l}\text { Engine } \\
\text { power }\end{array}$ & $115 \mathrm{~kW}$ & $115 \mathrm{~kW}$ & $81 \mathrm{~kW}$ & $77 \mathrm{~kW}$ \\
\hline $\begin{array}{l}\mathrm{CO}_{2} \\
\mathrm{~g} / \mathrm{km}\end{array}$ & 115 & 136 & 94 & 99 \\
\hline $\begin{array}{l}\text { Fuel cost } \\
€ / \mathrm{km}\end{array}$ & 0.063 & 0.094 & 0.057 & 0.075 \\
\hline List price & $€ 32,368$ & $€ 30,493$ & $€ 23,400$ & $€ 20,975$ \\
\hline
\end{tabular}

Source: Company websites, author's analysis and http://www.spritmonitor.de/

With the exception of Fiat the NGV range offered by other manufacturers is quite limited and those that are available are restricted to certain countries. Fiat offer six different NGV versions of their models to Italian buyers though this is likely to reflect the subsidy regime in Italy which encourages the purchase of CNG vehicles.

Overall the impression is that manufacturers are not placing a great deal of emphasis on NGV cars in their product offering. 

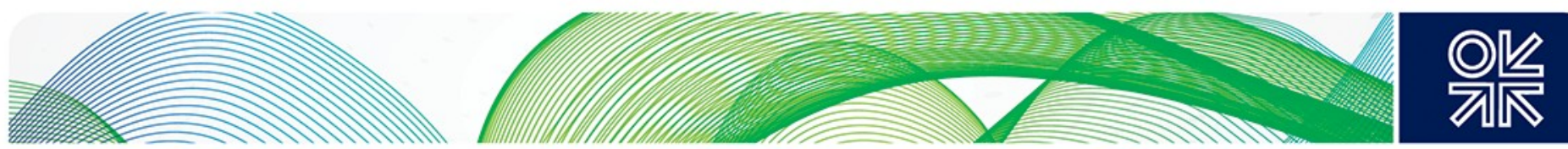

\subsubsection{Infrastructure providers}

Cars and light vehicles will exclusively rely on CNG refuelling stations. The number of existing and planned CNG refuelling stations is shown in Table 12. There are around 3,500 presently in operation and $89 \%$ of these are open to the public. Countries with a higher proportion of private stations are France, Netherlands and Sweden. $63 \%$ of all CNG stations in the EU are in just two countries - Italy and Germany - and the lack of widespread network is clearly a major inhibiting factor to future growth in demand for NGVs in this sector. According to the GasHighway project there are over 300 biomethane refuelling stations out of the 2,482 CNG stations in the $\mathrm{EU}^{142}$.

Whilst some increase in CNG refuelling provision is planned, any large-scale expansion by infrastructure providers is unlikely without significant external intervention and funding from policy makers.

More detailed consideration of the infrastructure issues and costs for all NGV road users is in section 5.5 .

\subsubsection{Policy makers}

Policy makers will have an impact at a European and national level. The main areas of intervention are in emission legislation, vehicle and fuel taxes/incentives and other incentives to encourage investment in either infrastructure, new vehicles or R\&D. Governments and policy makers will typically be targeting outcomes in terms of emissions rather than a particular transport solution though they inevitably get drawn into choosing one mode over another and can be accused of trying to pick winners.

One of the main policy tools in Europe has been emissions control standards and legislation. EU legislation adopted in 2011 set emission performance standards for LDVs. The standards for cars are applied to manufacturers who were required to meet a limit in 2012 of $130 \mathrm{gCO}_{2} / \mathrm{km}$ for $65 \%$ of all vehicle types built in that year. By 2015 this limit has to be met by all vehicles produced and by 2020 the limit falls to $95 \mathrm{gCO}_{2} / \mathrm{km}^{143}$. The standards for LCVs also applies to fleet owners though they have until 2017 to reach an average of $175 \mathrm{gCO}_{2} / \mathrm{km}$ falling to $147 \mathrm{gCO}_{2} / \mathrm{km}$ by 2020 . The EU average for LCVs in 2007 was $203 \mathrm{gCO}_{2} / \mathrm{km}^{144}$.

Table 15 shows a comparison of simulated fuel performance for an internal combustion engine and hybrid electric vehicle based on simulations undertaken by the European Commission's Joint Research Centre (JRC) as part of a comprehensive well to wheel analysis of future automotive fuels and power trains in Europe ${ }^{145}$.

\footnotetext{
${ }^{142}$ GasHighWay (2012)

${ }^{143}$ See European Commission (2009d) and (2011b)

${ }^{144}$ IGU (2012)

${ }^{145}$ See http://iet.jrc.ec.europa.eu/about-jec/downloads
} 

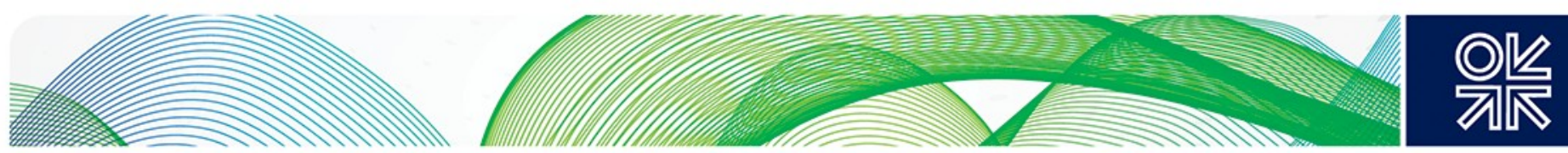

Table 15: Simulated energy and environmental TTW performance for cars

\begin{tabular}{|l|l|l|l|l|}
\hline \multirow{2}{*}{$\begin{array}{l}\text { Fuel } \\
\text { (ignition } \\
\text { source }\end{array}$} & \multicolumn{3}{|l|}{ Internal Combustion Engine } & \multicolumn{2}{l|}{ Hybrid Electric Vehicle } \\
\cline { 2 - 5 } & $\begin{array}{l}\text { Fuel } \\
\text { consumption } \\
\text { MJ/100km }\end{array}$ & $\begin{array}{l}\text { GHG Emissions } \\
\mathrm{gCO}_{2} \text { eq/km* }\end{array}$ & $\begin{array}{l}\text { Fuel } \\
\text { consumption } \\
\text { MJ } / 100 \mathrm{~km}\end{array}$ & $\begin{array}{l}\text { GHG Emissions } \\
\mathrm{gCO}_{2} \text { eq/km* }\end{array}$ \\
\hline Diesel (CI) & 162.5 & $150.3-155.8$ & 141.7 & 105.6 \\
\hline CNG (SI) & $211.8-232.3$ & $121.0-132.6$ & - & 95.6 \\
\hline LPG (SI) & $207.8-215.7$ & $137.3-142.5$ & - & - \\
\hline FAME (CI) & 162.5 & 125.0 & 128.0 & - \\
\hline DME (CI) & 171.8 & 116.8 & - & 99.4 \\
\hline $\begin{array}{l}\text { Ethanol } 85 \% \\
\text { (SI) }\end{array}$ & $198.6-207.1$ & $142.8-148.9$ & 138.1 & 100.3 \\
\hline HVO(CI) & 162.5 & 116.3 & 128.0 & 92.5 \\
\hline
\end{tabular}

Source: JEC Joint Research Centre-EUCAR-CONCAWE collaboration, Tank to Wheels Report 2013, based on range of power train configurations for a 1.3 to 1.4 tonne vehicle

*Tank to Wheel - includes $\mathrm{CO}_{2}, \mathrm{CH}_{4}$ and $\mathrm{N}_{2} \mathrm{O}$

${ }^{* *} \mathrm{SI}=$ spark ignition, $\mathrm{Cl}=$ compression ignition

Table 15 shows that for existing technology on an output per kilometre basis diesel and hybrid electric vehicles offer equivalent or better tank to wheel environmental performance than CNG. The performance for plug-in hybrids is even better. JRC have simulated the impact of technology improvements to 2020 and the gap with CNG closes (from between $83.0 \mathrm{gCO}_{2} \mathrm{eq} / \mathrm{km}$ and $87.4 \mathrm{gCO}_{2}$ eq $/ \mathrm{km}$ for CNG compared to $88.2 \mathrm{gCO}_{2} \mathrm{eq} / \mathrm{km}$ for diesel) though the performance for a diesel HEV is still better at $65.9 \mathrm{gCO}_{2} \mathrm{eq} / \mathrm{km}^{146}$. It should be noted that electric power from HEVs is generated on board the vehicle - the environmental impact on a TTW basis for plug in vehicles would be zero though the picture on a WTW basis would be very different as discussed below.

As we have noted, the calculations in Table 15 are not on a full well to wheel basis. These calculations were done in an earlier report and whilst not directly comparable to the numbers in Table 15 they do provide a very useful overview and are shown in Table 18. An assessment on a WTW basis makes a big difference in two specific areas: 

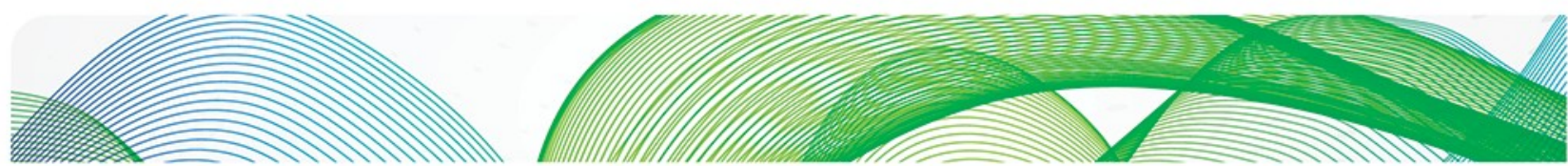

- Biomethane becomes much more attractive (see Table 7). Whilst the figures in this table are on a per MJ basis, so not directly comparable, it is clear that some forms of biomethane hold significant advantages over other fuels on a full WTW basis.

- Battery electric vehicles (BEV) and plug-in hybrids (PHEV) become much less attractive as the full impact of the generation and distribution of electricity is taken into account.

Batterbee \& Lidstone (2013) suggests that main options for the policy maker in trying to reduce the environmental impact of light vehicles are as follows:

- Improve performance of fossil fuels

- Improve efficiency through lighter structures, improved aerodynamics and power train efficiency

- Electrification - pure battery vehicles or plug-in hybrids

- Bio-fuels

- Hydrogen - either via fuel cells or into internal combustion engines

Batterbee argues that to achieve the long term climate goals policy makers should encourage continued improvements in efficiency in the conventional sector (including incorporating biofuels) whilst making the necessary investments to enable an electric vehicle infrastructure which would lead to a largely carbon neutral light vehicle system. If this view is widely shared - and given the lack of compelling environmental benefits - policy makers may conclude that active promotion of NGVs in this sector does not present a particularly attractive long-term option and that efforts should primarily be directed towards electric passenger vehicles.

However one critical aspect concerning the electrification of road transport is the full WTW impact of externally chargeable electric vehicles (i.e. pure battery-electric and plug-in hybrids). This will of course be a function of alternative pathways for the generation and distribution of electricity. The "EU mix" used in the EU WTT analysis ${ }^{147}$ is based on the 2009 split of primary energy sources for electricity production. This allocation is shown in Table 16 together with the latest information available, which is for 2011.

Table 16: Gross electricity generation - main sources

\begin{tabular}{|l|c|c|}
\hline Source & 2009 & 2011 \\
\hline Nuclear & $33.0 \%$ & $27.6 \%$ \\
\hline Coal lignite and peat & $31.0 \%$ & $25.9 \%$ \\
\hline Natural gas & $20.8 \%$ & $22.2 \%$ \\
\hline Renewable (including hydro) & $11.8 \%$ & $21.3 \%$ \\
\hline
\end{tabular}

Source: JEC Joint Research Centre-EUCAR-CONCAWE collaboration, Tank to Wheels Report 2013 see Edwards et al (2013) and http://ec.europa.eu/energy/publications/doc/2013_pocketbook.pdf

How this mix and the subsequent delivery elements impacts on GHG emissions is shown in Table 17. This table also shows the calculated delivered emissions from coal and natural gasfired power stations. It can be seen from Table 16 that the share of renewables has increased - though to some degree at the expense of nuclear. Whilst the $\mathrm{CO}_{2}$ equivalent emissions from delivered electricity will have fallen slightly they are still likely to be significantly above the total WTW combustion figures shown in Table 7.

${ }^{147}$ Edwards et al (2013) 

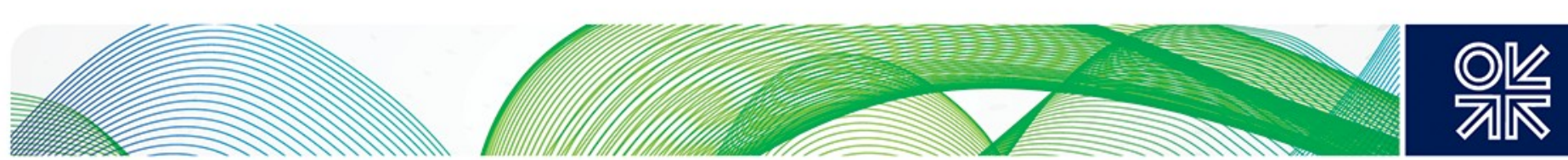

Table 17: GHG emissions from the electric vehicle pathway

\begin{tabular}{|l|c|c|}
\hline Stage & $\mathrm{gCO}_{2} \mathrm{eq} / \mathrm{kWhe}$ & $\mathrm{gCO}_{2} \mathrm{eq} / \mathrm{MJe}$ \\
\hline $\begin{array}{l}\text { Gross Electricity Production including primary fuel } \\
\text { provision (2009 EU Mix) }\end{array}$ & 457 & 127 \\
\hline $\begin{array}{l}\text { Net Electricity Production including primary fuel } \\
\text { provision }\end{array}$ & 476 & 132 \\
\hline Delivered LV electricity including distribution & 540 & 150 \\
\hline $\begin{array}{l}\text { Delivered LV electricity including distribution } \\
\text { Conventional coal (43.5\% efficiency) }\end{array}$ & & 292.4 \\
\hline $\begin{array}{l}\text { Delivered LV electricity including distribution } \\
\text { Natural gas (IGCC) }\end{array}$ & & 145 \\
\hline
\end{tabular}

Source: JEC Joint Research Centre-EUCAR-CONCAWE collaboration, Well to Tank Report 2013 - see Edwards et al (2013)

However the figures in Table 17 only tell part of the story. Because electric vehicles are more efficient than internal combustion engines a true comparison of the fuels has to be on a WTW basis per kilometre travelled. This is shown in Table 18.

Table 18: Well to Wheel comparison for selected fuel pathways

\begin{tabular}{|l|c|c|c|}
\hline \multirow{2}{*}{ Fuel pathway } & \multicolumn{3}{|c|}{ Average GHG Emissions $\mathrm{gCO}_{2}$ eq/km } \\
\cline { 2 - 4 } & TTW & WTT & WTW \\
\hline Gasoline (SI) & 140 & 27 & 167 \\
\hline Gasoline (SI) Hybrid & $114-120$ & $22-23$ & $136-143$ \\
\hline Diesel (CI) & $120-123$ & 26 & $145-149$ \\
\hline Diesel (CI) Hybrid & $96-99$ & $20-21$ & $117-120$ \\
\hline CNG (SI) & $108-109$ & $16-42$ & $124-150$ \\
\hline CNG (SI) Hybrid & 81 & $12-31$ & $93-112$ \\
\hline CBG (SI) & $108-109$ & -59 to -263 & -155 to 49 \\
\hline CBG (SI) Hybrid & 81 & -44 to -196 & -115 to 37 \\
\hline PHEV & & & $92-126$ \\
\hline BEV & & & $60-76$ \\
\hline
\end{tabular}

Source: JEC Joint Research Centre-EUCAR-CONCAWE collaboration, Well to Wheels Report 2011 Appendix 1 and 2 see Edwards et al (2011)

*Based on $\mathrm{EU}$ electricity mix with $\mathrm{GHG}$ emissions of $467 \mathrm{gCO}_{2} \mathrm{eq} / \mathrm{kWh}$, this is slightly higher than the figure in table 17 as the share of renewables was lower

Table 18 confirms that biomethane presents the best performance in terms of GHG emissions per kilometre travelled from those shown, with the range reflecting different sources of biogas - though as we have noted $100 \%$ biomethane may not be realistic and a 20/80 CBM/CNG blend may be more appropriate. BEVs emit approximately half the GHG per kilometre 

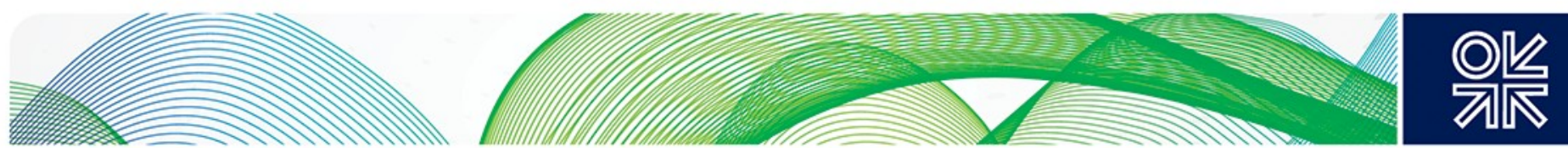

compared to CNG vehicles though range limitations presently restrict the attractiveness of these vehicles whilst PHEVs are only slightly more attractive than CNG vehicles.

On the figures presented, if a fully (or even significantly partly) decarbonised electricity supply was in prospect within a reasonable timescale then a full commitment by policy makers to electric vehicles would have some merit. However given the uncertainties surrounding the availability of biogas and the future power generation mix it could be argued that governments should adopt a more nuanced approach in order to avoid becoming stuck in a technological blind alley. The merits of a broader based policy have been given further support by the January 2014 decision to target a $27 \%$ renewable energy share for the EU as a whole by $2030^{148}$

Finally it should be noted that the foregoing discussion has excluded vehicles fuelled by hydrogen fuel cells. These are still seen as a distant prospect in the context of this discussion.

\subsubsection{Prospects for growth}

As shown in Table 12 the share of NGVs in the EU transport sector is presently $0.4 \%$ though in some countries the concentration is higher - notably Italy. As we have seen the high growth in this country is in part due to a generous subsidy scheme encouraging the purchase of NGVs, though continued expansion has been restricted by a lack of refuelling stations in some parts of the country and on motorways. The recent evolution of NGV ownership in Italy (together with Germany for comparison) is shown in Figure 19 which suggests there is still scope for expansion despite the inhibiting factors identified, though more widespread expansion in the European LDV sector is most likely to be dependent on a combination of enhanced subsidies and a major expansion of the refuelling network.

Figure 19: NGV growth in Italy and Germany 2007 - 2013 (Number of LDVs)

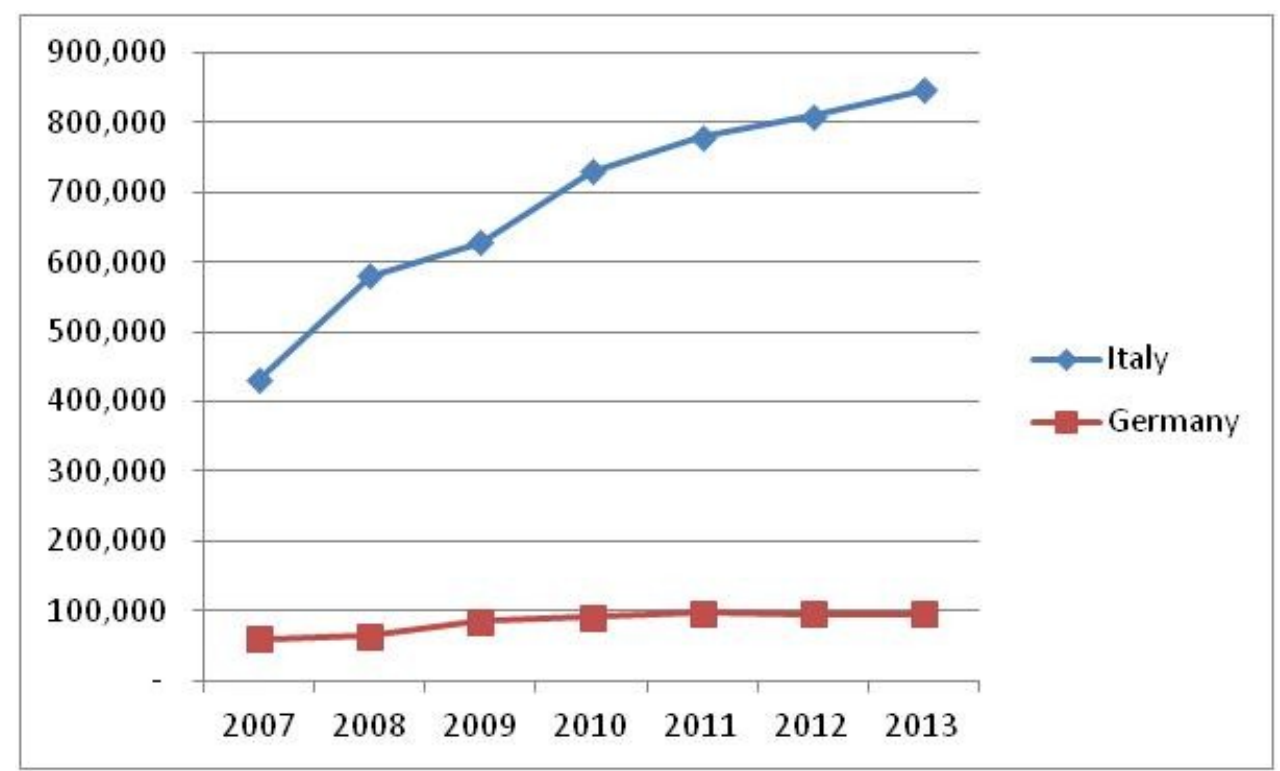

Source: NGVA Europe and the GVA 

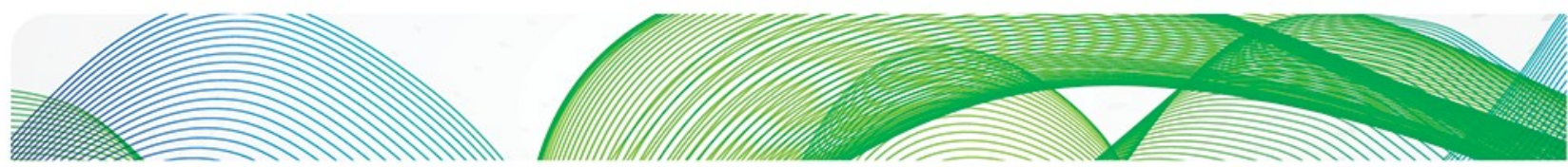

The growth projections in this study are based on an assumption that a range of further incentives coupled with network expansion occurs and that the switch to CNG vehicles will take place at the time of normal vehicle replacement. In the EU the number of new car registrations per year is presently in the region of 12 to 14 million - though prior to 2008 the figure was between 14 and 15 million ${ }^{149}$. The present rate of new car buying represents around $6 \%$ of the total car parc in the EU and this rate has been applied to the total population of cars and LCVs in Europe.

Three scenarios have been adopted to reflect differing rates of expansion that result in ultimate market shares of $1 \%, 2 \%$ and $5 \%$ by 2025 . The results are presented in Table 19.

Table 19: Projected market share in car and LCV market for Europe

\begin{tabular}{|c|c|c|}
\hline Ultimate Market share in & \multicolumn{2}{|c|}{ Projected Consumption in bcm } \\
\cline { 2 - 3 } $2025(\%)$ & 2020 & 2025 \\
\hline 1 & 7 & 9 \\
\hline 2 & 10 & 15 \\
\hline 5 & 20 & 33 \\
\hline
\end{tabular}

Source: Author's analysis - see appendix for assumptions and methodology

Data on sales of alternative fuelled vehicles from the top four car buying countries in the EU is shown in Table 20.

Table 20: Sales of non-diesel or petrol passenger cars in selected countries ( $\%$ of total)

\begin{tabular}{|l|l|l|l|l|l|l|l|l|l|l|}
\hline Cars & \multicolumn{2}{|c|}{ France } & \multicolumn{2}{c|}{ Germany } & \multicolumn{2}{c|}{ Italy } & \multicolumn{2}{c|}{ UK } & \multicolumn{2}{c|}{ EU total } \\
\hline & 2011 & 2012 & 2011 & 2012 & 2011 & 2012 & 2011 & 2012 & 2011 & 2012 \\
\hline Hybrid Electric & 0.6 & 1.3 & 0.4 & 0.7 & 0.3 & 0.5 & 1.2 & 1.2 & 0.7 & 1.1 \\
\hline Electric /Fuel Cell & 0.12 & 0.32 & 0.07 & 0.12 & 0.07 & 0.04 & 0.06 & 0.09 & 0.07 & 0.16 \\
& & & & & & & & & & \\
\hline CNG/LPG & 0.5 & 0.1 & 0.3 & 0.5 & 5.2 & 12.9 & 0 & 0 & 1.0 & 1.9 \\
\hline Ethanol/gasoline & 0.3 & 0.32 & 0.1 & 0.1 & 0 & 0 & 0 & 0 & 0.2 & 0.2 \\
\hline
\end{tabular}

Source: ICCT (2013)

The figures in Table 20 include LPG with CNG vehicles so should be treated with some caution though it would appear that with the exception of Italy hybrid electric and electric only vehicles are making some headway in the major car markets and are at least as popular as gas-fuelled vehicles.

\subsubsection{Cars and light commercial vehicles - conclusions}

The example of Italy shows that with the right government-supported incentives natural gas can achieve a significant and growing share of the car and LCV market. It is, however also clear that other options such as hybrids provide policy makers with broadly equal outcomes in terms of GHG emissions. Electric vehicles are potentially more attractive than CNG cars and a move in this direction may provide a route for ultimately de-carbonising the passenger car 

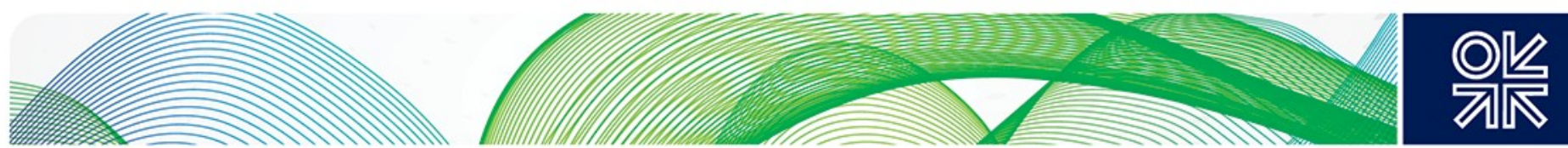

sector though this still seems some way off. Overall NGVs do represent a means of reducing emissions in a shorter time horizon than many other options. However despite this prospect some major car buying markets are pursuing alternative paths.

The financial case for NGVs in this sector is most compelling for owners with high levels of annual usage so fleet buyers may be more inclined to opt for CNG vehicles where these represent a viable alternative. However it remains the case that the range of CNG models is still restricted and the overall prospects for CNG in the wider European market must therefore be open to some doubt. On present evidence any growth in this sector is likely to be at the lower end of the market share assumptions.

There are however two possible exceptions to this conclusion. One is where gas in the form of biomethane is available in sufficient quantities and, critically, it would otherwise not find a market. The other exception could be where major quantities of indigenous shale gas are available - an outcome that does not presently seem likely in Europe.

Whilst overall the prospects for LCV NGVs may be less attractive than other transport sectors the huge size of the market means that even a small growth in market share could have a relatively large impact on gas demand and so should not be ignored.

\subsection{Buses}

Buses represent an interesting potential market for natural gas as these vehicles are nearly always back to depot operations, they frequently operate in urban environments and are often funded by public bodies keen to improve their environmental footprint.

NGVA statistics for the number of natural gas buses in Europe including Russia and Turkey are shown in Table 21. The number of buses includes minibuses, of which there are a very large number in Russia and Ukraine and a reportedly large number of NGV buses in the latter, which accounts for the very high proportion in "other Europe". As noted elsewhere in this report most of these vehicles are likely to be dual-fuelled and therefore actual levels of gas consumption are not thought to be very high.

Table 21: Natural gas buses in Europe, 2012

\begin{tabular}{|l|c|c|c|}
\hline & $\begin{array}{l}\text { Total buses } \\
\text { ('000) }\end{array}$ & NGVs & $\%$ NGVs \\
\hline EU & 748 & 13,168 & 1.76 \\
\hline Russia & 882 & 10,000 & 1.13 \\
\hline $\begin{array}{l}\text { Other } \\
\text { Europe }\end{array}$ & 1,287 & 255,000 & 19.8 \\
\hline Total & 2,917 & 278,503 & 9.5 \\
\hline
\end{tabular}

Source: NGVA Europe and the GVR

*Includes Turkey 

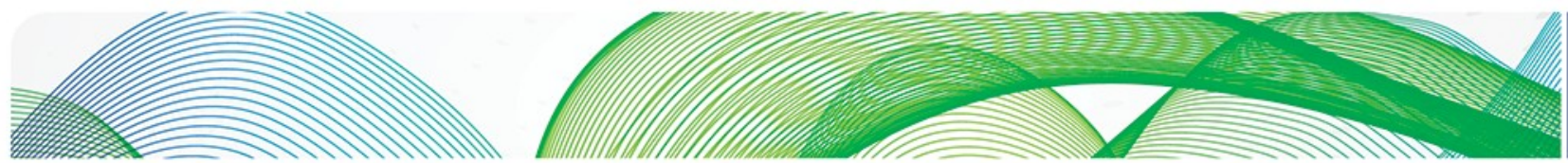

Whilst the overall share of NGV buses is not very high in the EU, penetration levels in some countries are notable. In particular Sweden (13.7\%), Netherlands (6.6\%) and Slovakia (3.7\%). There are also sizeable and growing markets in France, Spain and Poland.

\section{Figure 20: Key external factors and stakeholder map for buses}

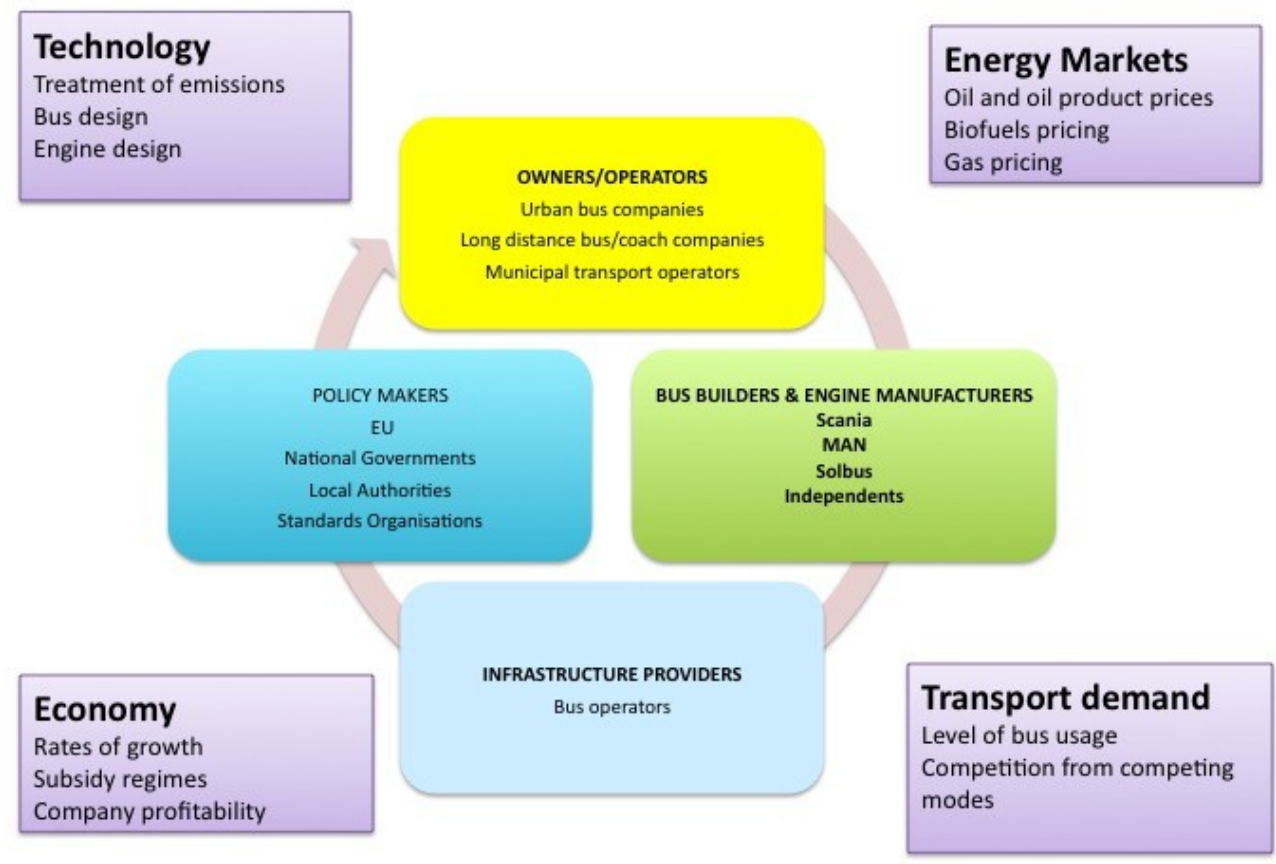

Source: Author based on Batterbee \& Lidstone (2013)

Figure 20 shows the key external factors and stakeholder map for buses. The position of policy makers is particularly important as they will play a role in procuring and subsidising bus transport as well as setting standards regarding emissions.

\subsubsection{Owners/operators}

Bus owners and operators are typically municipal undertakings or larger private companies with contracts or franchises for the provision of bus services. Urban bus transportation in Europe generally requires some form of subsidy which may be in the form of fuel or bus purchase subsidies and/or direct revenue grants; though operators are often incentivised to maximise profitability.

The owner operator will need to take account of a number of factors when considering bus procurement:

- Cost - both capital and operating/maintenance

- Operational effectiveness- this includes reliability, durability, depot logistics and refuelling, level of OEM support

- Attractiveness to passengers - comfort, accessibility

- Compliance with emissions and other legislation (e.g. disabled access, safety) 

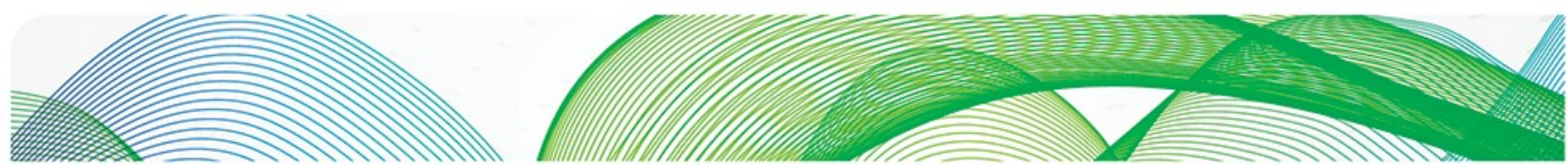

A NGV bus will typically have a purchase premium of 15 to $20 \%$ over a conventional diesel vehicle and operators will assess the merits of the new technology in terms of payback from lower fuel costs against the purchase premium.

There are a wide range of fuel options and other technologies available for buses though CNG is generally thought preferable to LNG as the required range is unlikely to be great. However CNG buses can have the disadvantages of longer refuelling times (15 versus 3 minutes for LNG, though fast fill options are now available for CNG) and greater height as the storage tank is usually roof mounted.

Research in the UK ${ }^{150}$ has compared a range of fuel options for buses including CNG, LNG and biomethane. The results are summarised in Table 22.

Table 22: Performance and economics of gas buses compared to diesel

\begin{tabular}{|l|c|c|c|}
\hline Option & $\begin{array}{l}\text { WTW } \mathrm{CO}_{2} \text { benefit } \\
\text { (\% compared to } \\
\text { diesel) }\end{array}$ & $\begin{array}{l}\text { Payback time for } \\
£ 45,000 \text { bus (years } \\
- \text { without fuel } \\
\text { subsidy }{ }^{151} \text { ) }\end{array}$ & $\begin{array}{l}\text { Payback time for } \\
£ 45,000 \text { bus (years } \\
- \text { with fuel subsidy) }\end{array}$ \\
\hline CNG & 5 to 16 & $8-12$ & $\begin{array}{c}\text { Break-even not } \\
\text { possible }\end{array}$ \\
\hline LNG & 4 to 23 & $5-8$ & $14-22$ \\
\hline Biomethane (CNG) & $143-146^{152}$ & $1-17$ & $1-13$ \\
\hline Liquid biomethane & 70 & \multicolumn{2}{|c|}{} \\
\hline
\end{tabular}

Source: Atkins et al (2013)

The picture can be hugely influenced by the nature of the subsidy regime. For example in the UK the BSOG (a fuel subsidy) means that the value of any fuel saving is reduced - though this can be outweighed by other considerations. This has a particular influence on NGV payback times as shown in Table 22. The range in payback times is due to the impact of providing a capital subsidy of $80 \%$ of the vehicle cost (which gives a much quicker payback) compared with the higher payback time if there is no subsidy for the new vehicle. The wider range of payback times for the biomethane cases reflect the extent to which an additional subsidy for the production of biomethane might or might not be available.

Other examples of payback calculations include:

- Gas Alliance of the UK reports investment paybacks of between 2 and 4 years for CNG buses based on biomethane ${ }^{153}$.

- In Poland operators require $1 \mathrm{~kg}$ of natural gas to be at least $75 \%$ below the cost of 1 litre of diesel before they are prepared to switch and quote a payback of 2 to 3 years for LNG buses. ${ }^{154}$.

\footnotetext{
${ }_{151}^{150}$ Atkins et al 2013

151 Including the existing fuel subsidy (BSOG) which only applies to diesel increases payback time

${ }^{152}$ Note a \% in excess of 100 implies a negative WTW CO2 impact

${ }^{153}$ Griffiths speaking at Natural Gas Vehicle Conference Amsterdam(25-26th Nov 2013)

${ }^{154}$ Solbus presentation at Natural Gas Vehicle Conference Amsterdam(25-26th Nov 2013)
} 

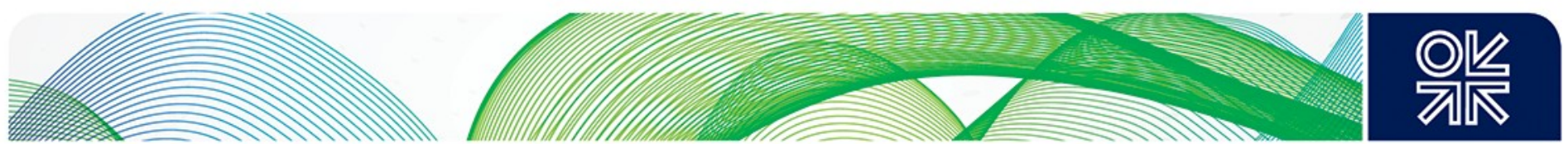

- In Madrid CNG buses have similar whole life cycle costs to diesel without subsidies and are preferred on grounds of lower emissions, noise and vibrations. Since 2010 the Municipality has only purchased CNG buses.

\subsubsection{Manufacturers}

The bus supply chain is characterised by relatively low volumes and localised markets. This means that it is difficult to achieve economies of scale and as a result the introduction of new technology can have a higher cost than other vehicle sectors. The premium for CNG/LNG buses is therefore likely to remain.

The main manufacturers in Europe include MAN, Scania, Mercedes and Solbus (Poland). Most manufacturers offer NGV options as well as biofuel and hybrid vehicles.

\subsubsection{Infrastructure providers}

Refuelling points will typically be embedded within operators' depots so the cost of infrastructure will be incorporated within the overall option (this tends to encourage large scale switching). The typically urban location and scale of operations may make the provision of CNG refuelling more economic and operationally easier than LNG.

Despite this Gazprom has developed a joint offering with bus manufacturer Solbus to lease vehicles, provide refuelling stations and a guaranteed supply of LNG and discount for the price of LNG to the prevailing diesel price.

More detailed consideration of the infrastructure issues and costs for all NGV road users is in section 5.5 .

\subsubsection{Policy makers}

Bus transport will be affected by not only the range of national and pan-European policies applied to the vehicular sector in general but also to a range of public transport-related measures emanating from local/regional sources as well as those already mentioned.

As well as issues such as Euro VI compliance local policies may also focus on noise and particulate emission reduction - both being particularly important in urban environments. As the local authority is often the provider or procurer of bus transport services it is in a strong position to ensure that its requirements are met. Whilst this can encourage innovation it can also result in a patchwork of different solutions with adjacent cities or regions adopting widely different solutions to meeting their urban bus requirements.

\subsubsection{Prospects for growth}

With the exception of Sweden and the Netherlands market shares are presently below $4 \%$ though a number of areas have shown growth potential and the zero particulate matter (PM) aspect is an attractive aspect for buyers in urban areas. On the other hand there is strong competition in this sector from other fuel sources - in particular hybrids and bio-fuels. The three scenarios adopted therefore reflect widely ranging market shares of $10 \%, 20 \%$ and $50 \%$ in 2025. The results are presented in Table 23, note that Ukraine and Russia have been excluded from the analysis due to the unreliability of the base data. 

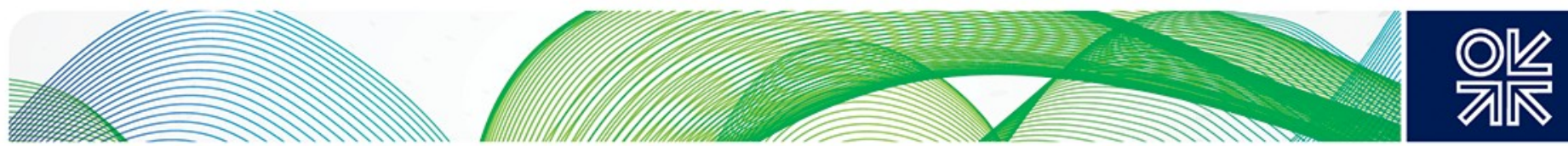

Table 23: Projected market share in bus market for Europe (Excluding Russia and Ukraine)

\begin{tabular}{|c|c|c|c|}
\hline Ultimate Market & Number of NGV & \multicolumn{2}{|c|}{ Projected Consumption in bcm } \\
\cline { 3 - 4 } share in 2025 (\%) & Buses in 2025 & 2020 & 2025 \\
\hline 10 & 96,000 & 2 & 3 \\
\hline 20 & 174,000 & 3 & 5 \\
\hline 50 & 408,000 & 7 & 12 \\
\hline
\end{tabular}

Source: Author's analysis - see appendix for assumptions and methodology

\subsubsection{Buses - conclusions}

Atkins et al (2013) conclude that CNG and biomethane technologies are suitable for bus use and whilst LNG is a possibility it is probably more suited to the HGV sector. Biomethane is also attractive in terms of its WTW $\mathrm{CO}_{2}$ reductions but "the widespread use.... is limited by fuel availability (partly due to competition with use for electricity generation) distribution and refuelling infrastructure."

Overall the bus NGV sector in Europe is therefore likely to grow though, even at very high market shares the overall impact on gas demand is relatively slight.

\subsection{Large commercial and freight vehicles}

This report defines HDVs as those in excess of 16 tonnes though it is not possible to get accurate statistics on the number of these vehicles across Europe for this category. This section therefore includes medium duty vehicles (typically between 3.5 and 16 tonnes) and the overall group is often referred to simply as trucks. The most prospective sector for gas demand is considered to be the HDVs.

NGVA statistics for the number of natural gas commercial vehicles (medium and large) in Europe including Russia and Turkey are shown in Table 24. This table includes the number of LNG and C-LNG refuelling stations which are primarily used by this sector.

The "Other Europe" figures include Ukraine which, as with the bus numbers, reports a very large number of NGV trucks ( $72 \%$ of MDV and HDVs). Again most of these vehicles are likely to be dual-fuelled and therefore actual levels of gas consumption are not thought to be very high. 

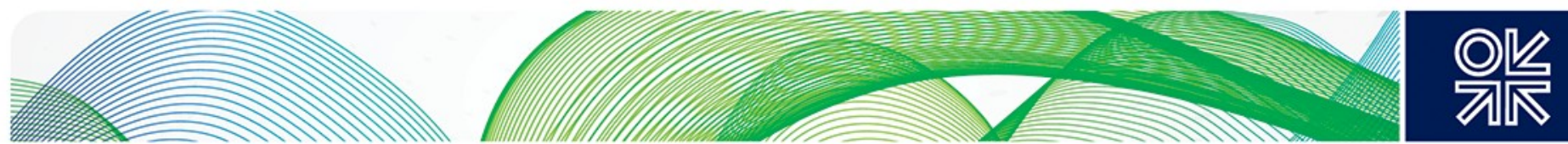

Table 24: Natural gas medium and large commercial vehicles and LNG refuelling stations in Europe, 2012

\begin{tabular}{|c|c|c|c|c|c|}
\hline & \multirow{2}{*}{$\begin{array}{l}\text { Total MDV } \\
\text { and HDV } \\
\text { (million) }\end{array}$} & \multirow[t]{2}{*}{$\begin{array}{l}\text { NGVs } \\
(' 000)\end{array}$} & \multirow[t]{2}{*}{$\%$ NGVs } & \multicolumn{2}{|c|}{$\begin{array}{l}\text { Number of LNG } \\
\text { refuelling stations }\end{array}$} \\
\hline & & & & LNG & C-LNG \\
\hline EU & 13.5 & 5.5 & 0.04 & 34 & 43 \\
\hline Russia & 5.2 & 15.0 & 0.29 & 1 & 0 \\
\hline $\begin{array}{l}\text { Other } \\
\text { Europe* }\end{array}$ & 1.6 & 170.8 & 10.2 & 4 & 1 \\
\hline Total & 20.3 & 191.4 & 0.9 & 39 & 44 \\
\hline
\end{tabular}

Source: NGVA Europe and the GVR

*Includes Ukraine and Turkey

Figure 21: Key external factors and stakeholder map for large commercial vehicles

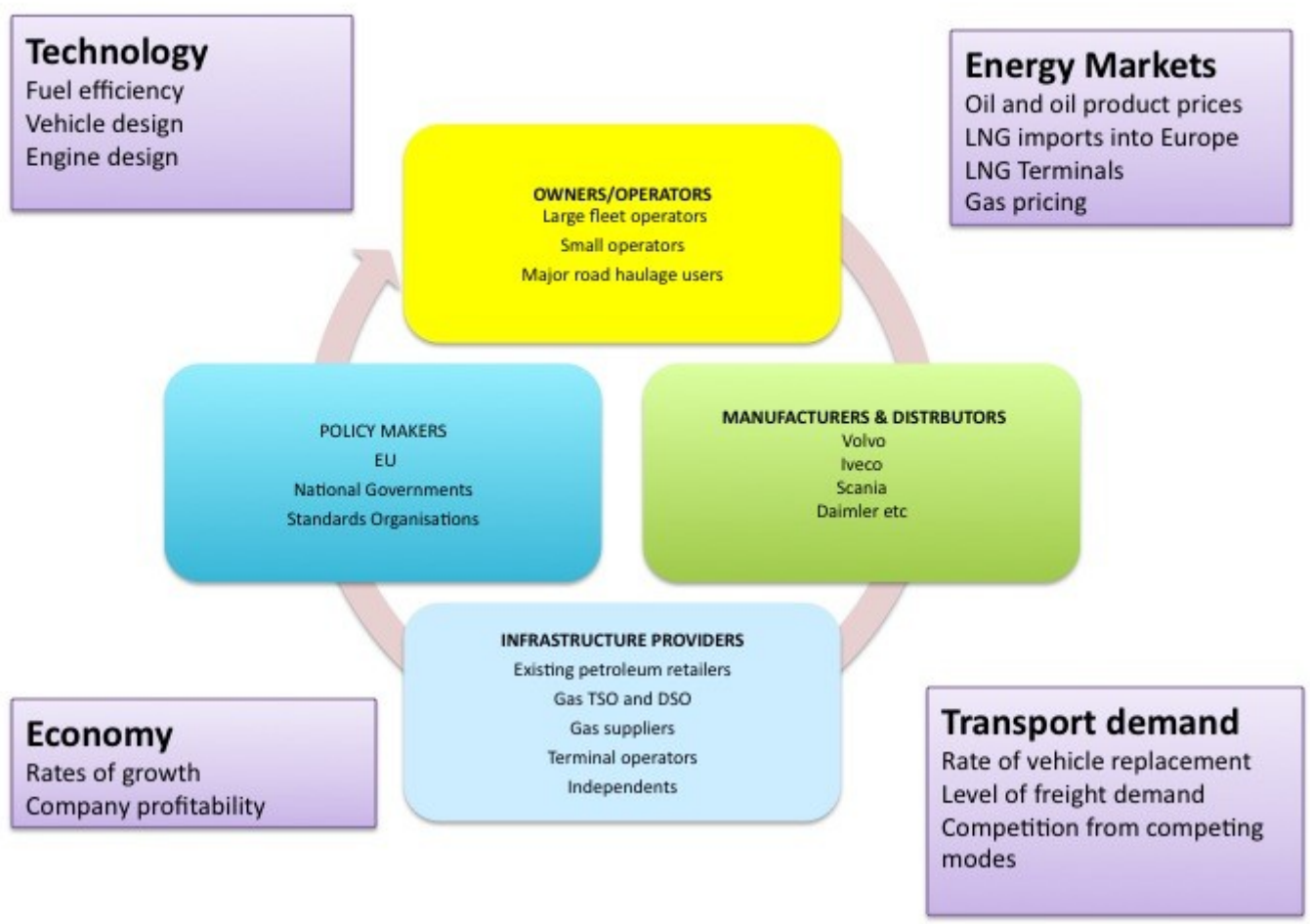

Source: Author based on Batterbee \&Lidstone (2013)

Figure 21 shows the key external factors and stakeholder map for trucks. The position of owners/operators is probably the most important factor in determining the future expansion of natural gas in this sector. 

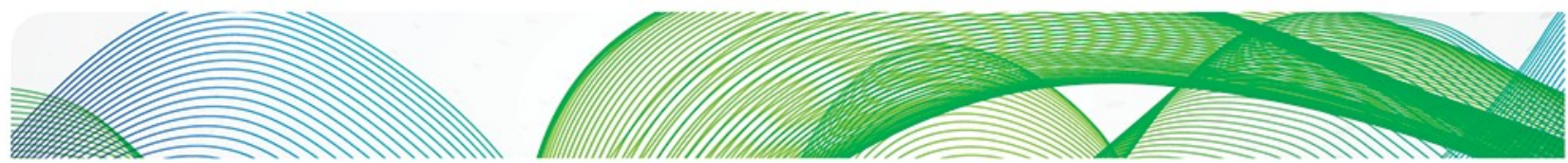
OKI

\subsubsection{Owners/operators}

As with buses overall financial considerations are the key factors in purchase decisions. These are a function of purchase price, fuel efficiency, ease of driving and resale value ${ }^{155}$.

The situation for commercial vehicles is simple in one respect in that the financial benefits can be relatively easily assessed and calculated and there can be reasonable confidence that these metrics will apply when it comes to making the vehicle purchase decision. However the picture is complicated by a number of factors.

First the vehicle buyers will generally be vehicle fleet operators - these can range from single owner-driver operations to huge multi-vehicle groups. An example of what this looks like is drawn from the UK where Table 25 shows the distribution of fleet size by number of operators.

Table 25: Distribution of commercial vehicle fleets - UK

\begin{tabular}{|l|r|}
\hline Size of fleet(vehicles) & Proportion of total of operators \\
\hline 1 & $\mathbf{5 0 . 0 \%}$ \\
\hline $2-5$ & $35.1 \%$ \\
\hline $6-10$ & $\mathbf{7 . 4 \%}$ \\
\hline $11-20$ & $\mathbf{4 . 1} \%$ \\
\hline $21-50$ & $\mathbf{2 . 4 \%}$ \\
\hline $51-100$ & $\mathbf{0 . 7 \%}$ \\
\hline More than 100 & $\mathbf{0 . 4 \%}$ \\
\hline
\end{tabular}

Source: UK VOSA

http://webarchive.nationalarchives.gov.uk/20130102233509/http:/www.dft.gov.uk/vosa/repository/The\% 20Heavy\%20Goods\%20Motor\%20Vehicle\%20Fleet\%202010-11.xls

The preponderance of small operators in Table 25 is striking. Smaller operators are likely to be very dependent on the existing dealership and re-fuelling network and any negative feedback concerning NGVs or concerns over fuel availability will have a marked impact. This will be exacerbated by the recognition that their livelihood is dependent on having a serviceable vehicle available at all times.

Discussions with various operators suggest that experience to date of NGVs has generally been positive though a number of drawbacks have been identified. These include:

- The price differential between natural gas and diesel fluctuates through time - and has narrowed appreciably of late - and by country ${ }^{156}$. Furthermore because tax accounts for $2 / 3$ of the difference in the UK? and fuel taxes are an important source of government revenue many commentators and users expect the tax gap between

\footnotetext{
${ }^{155}$ See http://www.automotivelogisticsmagazine.com/finished-vehicle-logistics/truck-fleet-purchasing-Isps-bettershop-around

${ }^{6}$ According to Citi the biggest gaps between gas and diesel excise duties are around US $\$ 16 / \mathrm{mmbtu}$ found in Belgium, the UK, Italy, France, Netherlands and Sweden. In Poland it is US $\$ 6.5 / \mathrm{mmbtu}$ and effectively zero in Denmark. Everywhere else was at least $\$ 10.5 / \mathrm{mmbtu}$.
} 

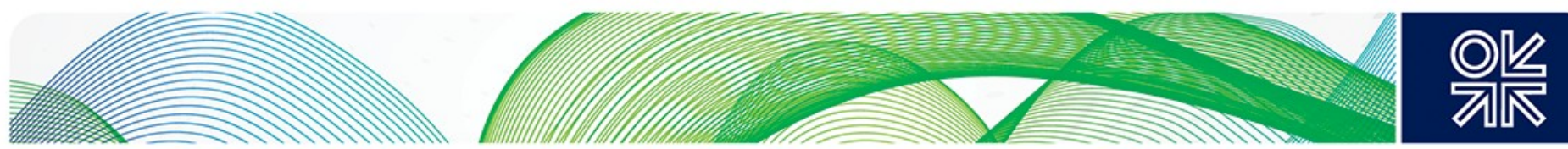

natural gas and diesel to narrow over time - a trend that may be accelerated by a move towards tax harmonisation across Europe.

- The premium paid for NGV trucks is around 35\% (it can be up to $40 \%$ in effect for a volume buyer due to the discount foregone) though this is not reflected in the resale value. Operating costs are generally higher and in some cases so are insurance costs.

- The present range of vehicles is under powered - though the gap is gradually closing.

- Occasional problems with LNG supply (e.g. the Avonmouth LNG plant in GB was out of action earlier in 2013 and LNG users had to bring in supplies from the Zeebrugge terminal).

- Present level of knowledge and facilities at truck service centres and problems over spare parts management can lead to extended downtimes.

- Different pressures and regulations at refuelling points coupled with boil off issues can create operational difficulties.

Whilst many of these issues could be classified as typical teething troubles with a new technology they will encourage many smaller operators, averse to risk taking, to wait before committing to NGVs despite the attractive economics.

At the other end of the scale the large operators will be more attuned to recent developments and prepared to innovate - albeit on a trial or pilot basis. They will also be able to invest in their own refuelling facilities. These groups will also be more susceptible to the reputational aspects associated with low carbon vehicles - particularly if they are part of the food or other retail supply chain with a strong high street presence. Even so they are unlikely to be willing to make large commitments to switching at this stage and financial aspects of any switch will still be critical.

In order to assess the nature of the financial trade-offs described above this study has calculated the break-even periods for diesel versus natural gas trucks based on the following assumptions $^{157}$ :

- Incremental capital cost of new vehicle $€ 50,000^{158}$ incurred at beginning of year 1

- Incremental repair and maintenance cost of new vehicle $€ 5,000$ pa

- Vehicle residual value after 6 years - no difference between dual fuel and conventional

- A pump price differential between LNG and diesel of $€ 20 / \mathrm{mmbtu}$ (including all taxes). This equates to $€ 0.43 / \mathrm{km}$ for diesel and $€ 0.28 / \mathrm{km}$ for $L N G$ assuming an effective fuel efficiency of 32 litres $/ 100 \mathrm{~km}$ and $27 \mathrm{~kg} / 100 \mathrm{~km}$ respectively.

- Two levels of diesel substitution - zero and $25 \%$

- Usage levels of 50,000, 100,000 and 150,000 km/year

The results are presented in Table 26 and shown graphically in Figure 22 and Figure 23. As would be expected these results confirm the importance of high utilisation in order to reap the benefits from lower cost of natural gas

\footnotetext{
157 These are based on industry sources and case studies reported in GRSG (2013)

${ }^{158}$ Industry sources in the UK suggest a premium of $£ 30,000$ for a 32 tonne rigid vehicle and $£ 35,000$ for a 44 tonne 3-axle tractor unit
} 

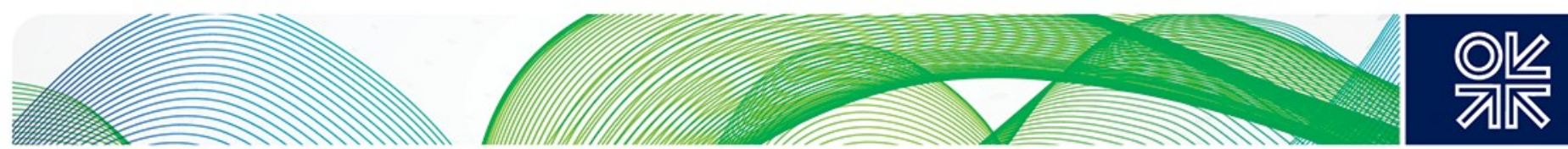

Table 26: Breakeven analysis for NGV truck v diesel

\begin{tabular}{|l|l|l|}
\hline \multirow{2}{*}{ Annual usage $(\mathrm{km})$} & Undiscounted payback (years) \\
\cline { 2 - 3 } & $100 \%$ Natural gas & $75 \%$ Natural gas \\
\hline 50,000 & $>10$ years & $>10$ years \\
\hline 100,000 & 5.5 years & 8.3 years \\
\hline 150,000 & 2 years & 4.4 years \\
\hline
\end{tabular}

Source: Author's analysis

Figure 22: Break-even calculations for new LNG truck - 100\% Natural Gas

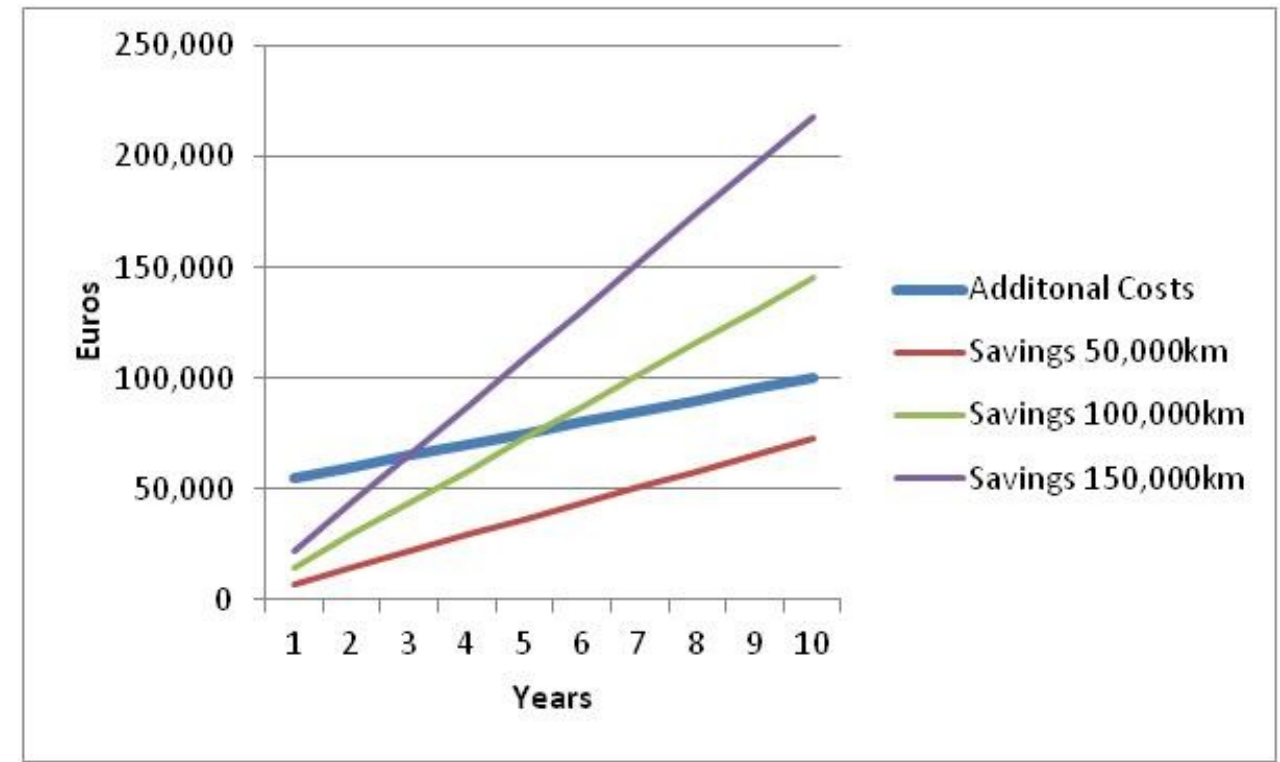

Source: Author's analysis

Figure 23: Break-even calculations for new LNG truck - 75\% Natural Gas

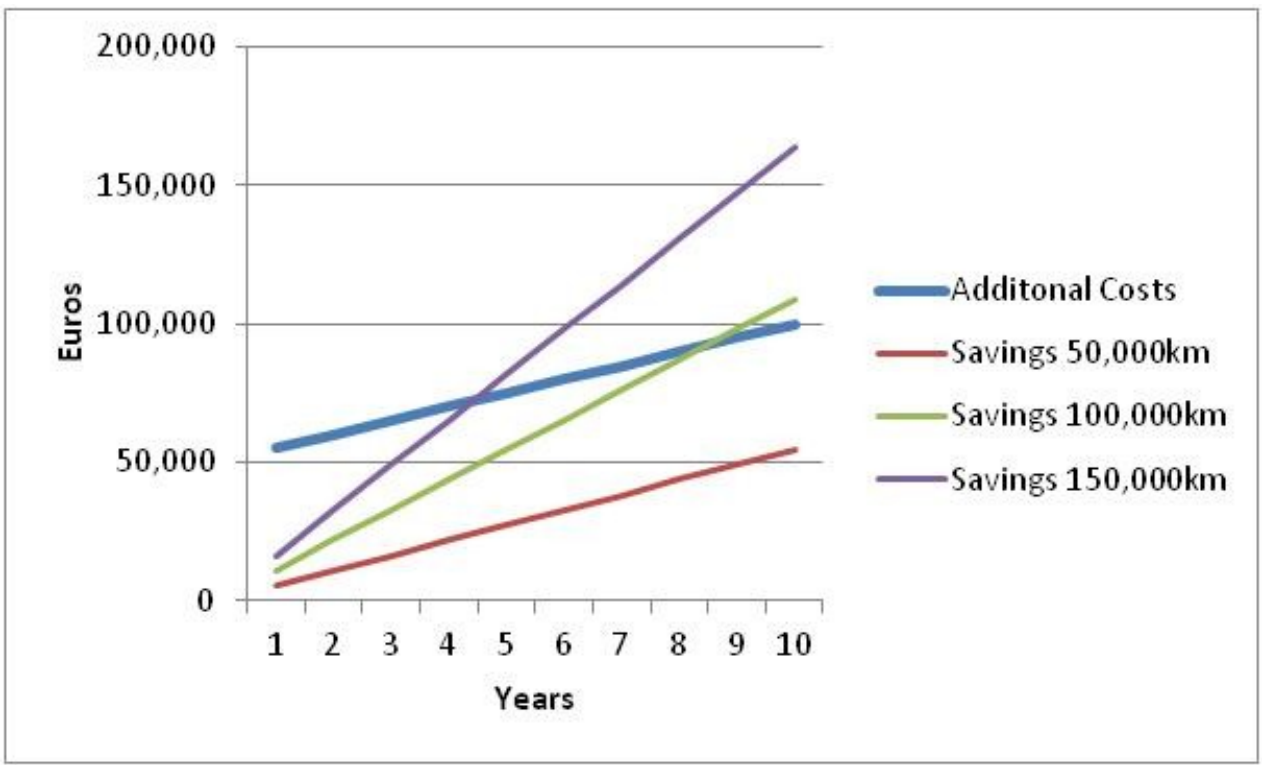

Source: Author's analysis 

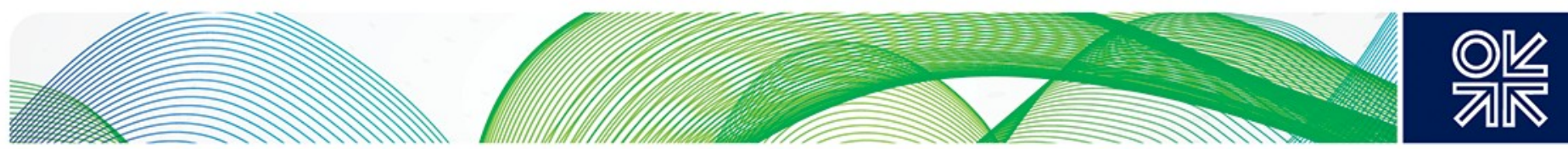

These results are confirmed by other studies. Citi calculate a saving in the US of around 12 cents/mile ${ }^{159}$ and that in Europe there is an approximately $\$ 2.8$ per equivalent gallon advantage of natural gas over diesel of which two thirds is a result of taxation differentials. For the UK they calculate a total gap of $\$ 3.8 /$ gallon ( $\$ 27.5 / \mathrm{mmbtu}$ ) equivalent due to the high differential between taxes. Running the economics for a range of assumptions they generate a payback of 2.8 to 2.5 years for a range of sensitivities.

This compares with a break-even period for a UK operator calculated by Brightman et $\mathrm{al}^{160}$ of between 2.4 and 9 years depending on the size of vehicle and whether CNG or LNG is used as a fuel. This study attributes higher costs for LNG than CNG due to higher refuelling costs for the former. Calculated payback times for biomethane are even longer as it is assumed that this will be priced at a premium due to the nature of the present UK incentive regime. In another study PWC has calculated a payback of 1.5 to 2 years (see Table 30 ).

One of the difficulties with this type of analysis is that it can be critically dependent on assumptions concerning refuelling station costs. Whilst this is potentially an important element it could be seen as unrealistic to load the entire cost of refuelling on to the marginal cost of fuel. In order to redress this the study has calculated a range of discounts to the price of diesel that would be necessary to meet the criteria of break even after 3 years (using the same assumptions as detailed above) as this is understood to be a typical period for evaluating a new truck purchase.

The results are shown in Table 27 and Figure 24, again illustrating the impact of annual usage on required discounts. Figure 24 also shows the current estimated discount between the prices paid for diesel and natural gas ${ }^{161}$ in France, Germany, Netherlands and UK. This suggests that to achieve a break-even within 3 years assuming a premium of $€ 50,000$ for a natural gas truck the operator will need to achieve annual utilisation rates in excess of 150,000 kilometres. The exception to this is the UK where a break-even is achieved at around $100,000 \mathrm{~km} / \mathrm{year}$ - this reflects the higher discount for natural gas as a result of the higher excise duties on diesel. In all cases the discount shown is heavily dependent on the lower level of duty for natural gas against diesel. This is illustrated in Table 28.

Table 27: Required discount for NGV truck v diesel to achieve breakeven within 3 years

\begin{tabular}{|c|c|c|}
\hline Annual usage $(\mathrm{km})$ & \multicolumn{2}{|c|}{ Required discount to diesel price (100\% natural gas) } \\
\cline { 2 - 3 } & $€ / \mathrm{km}$ & $\$ / \mathrm{mmbtu}$ \\
\hline 50,000 & 0.43 & $43.62^{*}$ \\
\hline 100,000 & 0.22 & 22.32 \\
\hline 150,000 & 0.14 & 14.20 \\
\hline
\end{tabular}

Source: Author's analysis

Note for reference, the January 2014 retail diesel price is approximately $\$ 51 / \mathrm{mmbtu}$ in Germany and $\$ 68 / m m b t u$ in $\mathrm{GB}$

\footnotetext{
${ }^{159}$ Citi (2013), diesel \$4/gallon, NG \$2.5/gallon

${ }^{160}$ Brightman et al 2011

${ }^{161}$ Diesel prices are from http://www.energy.eu/fuelprices/, natural gas prices are based on case studies in GRSG 2012 and the author's estimates
} 

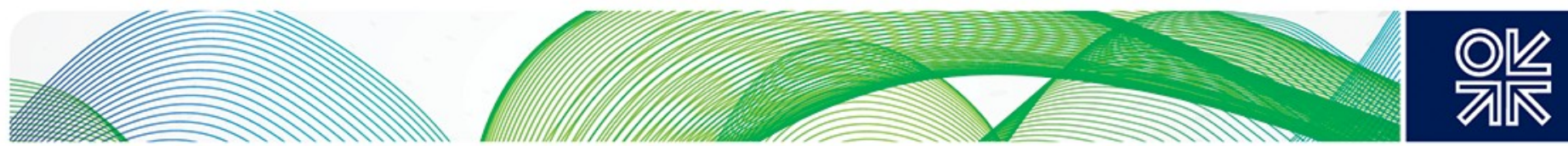

Figure 24: 3 year break-even $v$ estimated current discount of gas to diesel

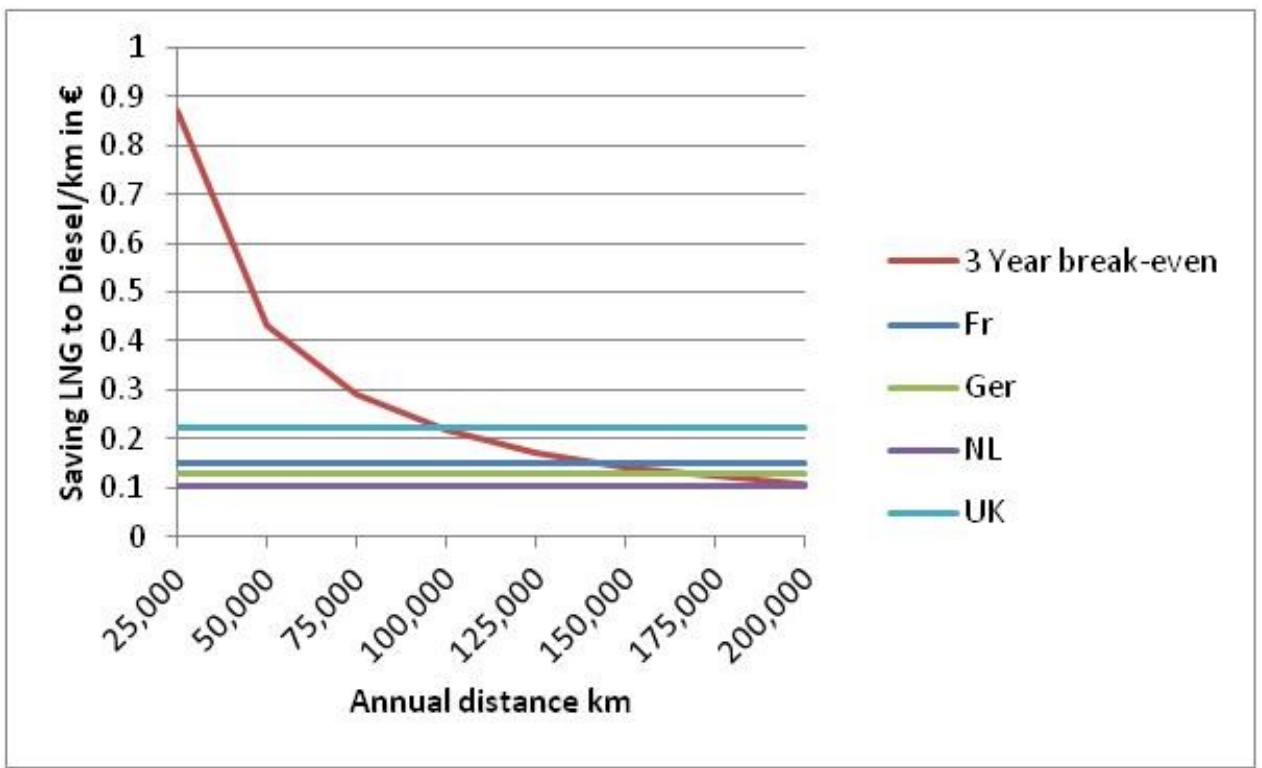

Source: Author's analysis

Table 28: Comparative fuel excise duties in $€$ per kilometre

\begin{tabular}{|l|c|c|c|}
\hline & Diesel & Natural Gas & Difference \\
\hline France & 0.137 & 0.000 & 0.137 \\
\hline Germany & 0.147 & 0.055 & 0.092 \\
\hline Netherlands & 0.141 & 0.075 & 0.065 \\
\hline UK & 0.214 & 0.094 & 0.121 \\
\hline
\end{tabular}

Source: Author's analysis based on tax information from European Commission (2013d). Note diesel rates (per litre) based on 32 litres $/ 100 \mathrm{~km}$ and natural gas rates (per GJ) on $27 \mathrm{~kg} / 100 \mathrm{~km}$ which is equivalent to $1.42 \mathrm{GJ} / 100 \mathrm{~km}$

It is clear from this analysis, and to be expected, that at present natural gas has a stronger financial advantage where operators have high levels of utilisation. Typically these will be trunk haulage activities so the importance of a comprehensive network of NGV refuelling stations is again emphasised. Over time this aspect could diminish if the volume of NG trucks manufactured increases and the premium consequently falls. This trend is confirmed in China where Shaanxi Automobile Group sell over 30,000 LNG trucks annually and the premium is around $€ 10,000$ to $€ 12,000$ above the diesel equivalent ${ }^{162}$. The other clear point is the importance of excise duties in ensuring the financial case is made and clarity on this from Governments will be a crucial factor.

One other question facing operators is the choice between LNG and CNG. The main considerations are summarised in Table 29 

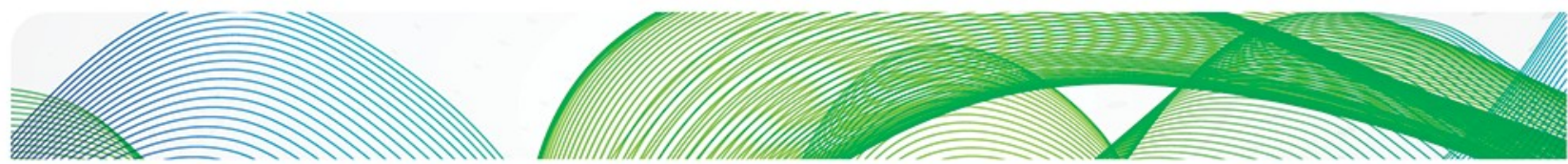

Table 29: Comparison of CNG v LNG for truck operators

\begin{tabular}{|l|l|l|}
\hline Consideration & LNG & CNG \\
\hline Range/utilisation & $\begin{array}{l}\text { Preferred where maximum } \\
\text { range is important and } \\
\text { utilisation high }\end{array}$ & $\begin{array}{l}\text { Preferred for back to base } \\
\text { operations with low mileage }\end{array}$ \\
\hline Vehicle weight & $\begin{array}{l}\text { Preferred for heavy weight } \\
\text { vehicles }\end{array}$ & $\begin{array}{l}\text { Preferred for light/medium } \\
\text { weight vehicles }\end{array}$ \\
\hline Refuel time & $\begin{array}{l}\text { Preferred where time to } \\
\text { refuel needs to be minimised }\end{array}$ & $\begin{array}{l}\text { Preferred where there is } \\
\text { plenty of time to refuel - e.g. } \\
\text { overnight }\end{array}$ \\
\hline Tank space & $\begin{array}{l}\text { Preferred where space is } \\
\text { limited }\end{array}$ & $\begin{array}{l}\text { May be preferred if there is } \\
\text { space for many tanks }\end{array}$ \\
\hline
\end{tabular}

Source: Industry representatives

In broad terms most of the industry representatives contacted as part of this study have expressed a greater interest in the scope for LNG rather than CNG in the trucks sector at the present time.

\subsubsection{Manufacturers}

As with cars most manufacturers operate on a global basis with companies and products tailored to a particular region or country. The main European manufacturers are:

- Volvo ${ }^{163}$ - the market leader in Europe; produces the dual-fuelled FM MethaneDiesel providing $460 \mathrm{bhp}$ - the company has sold over 400 LNG vehicles in Europe. A Euro $\mathrm{VI}$ version is under development and is due to be launched in $2015^{164}$.

- Daimler (Mercedes) - a leader in the USA (Freightliner) but not yet in Europe at the heavy end. Introducing the new Euro VI Econic NGT in mid 2014 which will be in the 200-300 bhp range ${ }^{165}$. Heavier duty Euro V (340-510 bhp) trucks are offered in cooperation with Hardstaff of the UK but timing for a Euro VI version is not yet clear $^{166}$. Mercedes-Benz also offers a smaller CNG Sprinter van.

- Scania do not presently actively market NGV trucks though in October 2013 they announced the launch of their Euro VI range which includes 280 or 340 bhp engine that "can be adapted to run on either CNG or LNG"167

- Iveco (Fiat) is a major producer of CNG vehicles for the Italian market via its Stralis range (272 bhp). The company has recently announced an LNG-fuelled version that will be Euro VI compliant and available in $2014^{168}$

There is a sense amongst many industry participants that the range of NGV trucks on offer is still too limited - particularly regarding the high powered (i.e. above $450 \mathrm{bhp}$ ) segment. From 2014 all new trucks sold must comply with stricter emission rules under Euro VI. This has led most manufacturers to concentrate on meeting this standard for their conventional diesel

\footnotetext{
${ }^{163}$ See http://www.volvotrucks.com/trucks/global/en-gb/trucks/new-trucks/Pages/volvo-fm-methanediesel.aspx

${ }^{164}$ M Franzen, Volvo speaking at Natural Gas Vehicle Conference Amsterdam(25-26th Nov 2013)

165 http://www.daimler.com/dccom/0-5-1591297-1-1591310-1-0-0-1591303-0-1-8-7163-0-0-0-0-0-0-0.html

166 http://www.hardstaffgroup.co.uk/site/hardstaff-dual-fuel-technologies/available-vehicles

${ }^{167}$ http://www.scania.co.uk/(S(ocobxsre41wtbp20urmmiz55))/about-scania/media/calendar/2013/complete-euro-6range.aspx?tab=5

168 http://www.iveco.com/en-us/press-room/kit/Pages/3-RAISTRALISLNG.aspx
} 

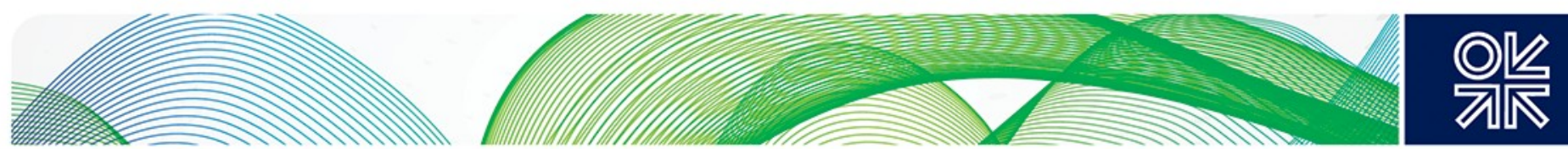

offerings and as a result NGV developments have arguably slipped somewhat. Now that these requirements have been met many industry participants expect more progress to be made with new NGV models. However, volume manufacturing of NGV trucks would still appear to be some way off.

\subsubsection{Infrastructure providers}

For "back to depot" type operations using CNG it is quite likely that the operator will use a private refuelling facility located at or near the depot - though as shown below the costs of this option can be very high. For long haul operators the availability of a comprehensive network of LNG refuelling stations will be vital.

More detailed consideration of the infrastructure issues and costs for all NGV road users is in section 5.5 .

\subsubsection{Policy makers}

As with other forms of road transport one key objective of policy makers concerns the reduction in GHG emissions. In addition to a general objective of reducing these, $\mathrm{No}_{x}$ and particulates (PM) are a key health concern in city centres where nitrogen dioxide $\left(\mathrm{NO}_{2}\right)$ is a lung irritant which can cause respiratory disorders. Fine PM particles can cause lung disorders and inflammation and are carriers of carcinogenic compounds.

A uniform approach to the measurement of $\mathrm{CO}_{2}$ emissions from HDVs is much more complex than with LDVs as there are much greater differences arising from the nature of the operation and the time the vehicle is utilised. At present the test for emissions is done on an engine rather than a vehicle basis. An alternative approach using model-based simulation of the whole vehicle is under consideration and should be finalised in 2014. In the meantime the standard is set by the Euro VI regulations.

Table 30 shows a comparison provided by PWC of environmental performance and full life cost calculations of an LNG truck versus a conventional vehicle using Euro VI compliant fuel. The additional investment for an LNG solution can be recovered over between 1.5 and 2.1 years according to the PWC analysis ${ }^{169}$. The ranges reflect different fuel configurations (i.e. dual-fuelled, diesel injection or dedicated LNG) for the LNG truck. As would be expected the dedicated LNG option has the quickest pay back time. 

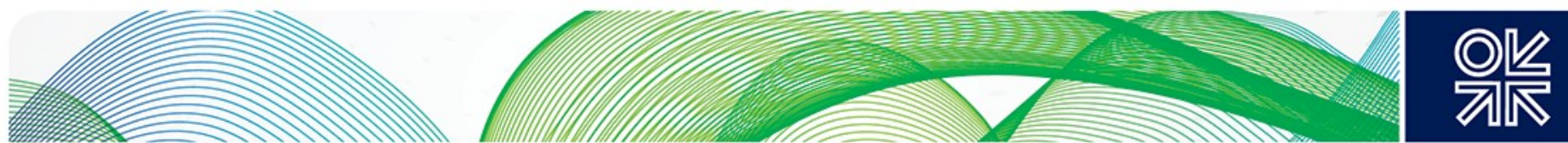

Table 30: Comparison of alternative truck fuelling options

\begin{tabular}{|l|l|l|l|l|}
\hline & $\begin{array}{l}\text { Nox } \\
(2014)\end{array}$ & Particles & $\mathrm{CO}_{2}$ & $\begin{array}{l}\text { Life } \\
\text { cycle } \\
\text { cost } \\
€^{\prime} 000\end{array}$ \\
\hline $\begin{array}{l}\text { Euro VI reduction } \\
\text { target }\end{array}$ & $-80 \%$ & $-67 \%$ & $-0 \%$ & \\
\hline $\begin{array}{l}\text { Euro VI } \\
\text { compliant diesel }\end{array}$ & $-80 \%$ & $-95 \%$ & $0 \%$ & $330-344$ \\
\hline LNG & $-90 \%$ & $-95 \%$ & $-8 \% 170$ & $252-285$ \\
\hline
\end{tabular}

Source: PWC (2013)

Actual performance can differ from that claimed by manufacturers. An example of the difference is shown in Table 31 based on a trial by Coca Cola using liquefied biomethane $(\mathrm{LBM})^{171}$. This trial demonstrated a WTW $\mathrm{CO}_{2}$ saving of $60 \%$ and reduced $\mathrm{No}_{\mathrm{x}}$ and $\mathrm{PM}$ emissions by $85.6 \%$ and $97.1 \%$ respectively. However the trial also showed the WTT performance was affected by dispensing emissions associated with the trial station. A further issue was the degree of methane slip leading to a significant increase in unburnt hydrocarbons - this aspect is being addressed by OEMs.

Table 31: Actual environmental performance of gas $v$ diesel trucks

\begin{tabular}{|l|c|c|}
\hline Emission & Gas truck (g/km) & Diesel truck (g/km) \\
\hline Nox & 0.539 & 3.799 \\
\hline Particulate Matter & 0.002 & 0.069 \\
\hline Carbon Monoxide & 2.223 & 1.776 \\
\hline Unburnt hydrocarbons & 0.127 & 0.032 \\
\hline
\end{tabular}

Source: Cenex (2013)

It is therefore clear that in order to ensure that the environmental benefits claimed by LNG are actually delivered it is vital that the supply chain is leak proof. In the case of LNG this requires active boil-off and venting management. Some of the early LNG stations were reported to have a poor record in this regard though companies such as Cryostar have developed refuelling systems that include vent gas recovery systems and vacuum insulated lines that deliver minimal loss of gas ${ }^{172}$. 

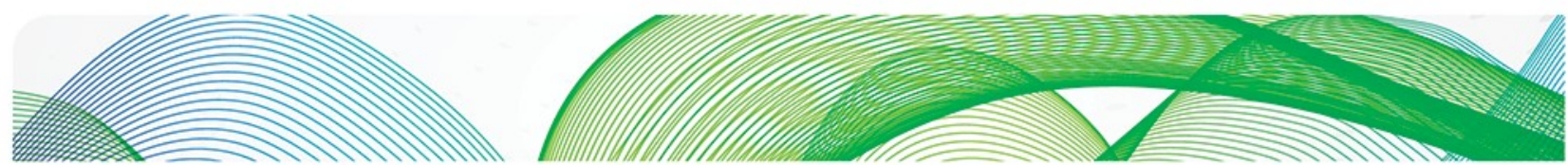

\subsubsection{Prospects for growth}

The calculation of market shares for the medium and large commercial vehicle sector is complicated by the huge range of vehicle sizes and usage patterns. In broad terms there are approximately 20 million medium and heavy duty commercial vehicles in Europe ${ }^{173}$ and of these around 2 million could be classed as HDVs. It is these vehicles that are most likely to offer prospects for natural gas (and LNG in particular) so the growth projections in this study have focussed on this sector. Three scenarios have been adopted to reflect market shares of $2 \%, 10 \%$ and $20 \%$ in 2025 assuming an average annual consumption of $60,000 \mathrm{~m}^{3}$ of natural gas and a fuel efficiency improvement rate of $2 \%$ pa. The results are presented in Table 32.

Table 32: Projected market share in the large truck market for Europe (excluding Russia and Ukraine)

\begin{tabular}{|c|c|c|c|}
\hline Ultimate Market & Number of NGV HDVs & \multicolumn{2}{|c|}{ Projected Consumption in bcm } \\
\cline { 3 - 4 } share in $2025(\%)$ & in 2025 & 2020 & 2025 \\
\hline 2 & 44,000 & 1.3 & 2.1 \\
\hline 10 & 204,000 & 5.5 & 9.8 \\
\hline 20 & 408,000 & 10.8 & 19.5 \\
\hline
\end{tabular}

Source: Author's analysis - see Appendix A for assumptions and methodology

The high case takes a figure of $20 \%$ as ultimate market share. In the HGV market this results in additional gas consumption of around $20 \mathrm{bcm} /$ year by 2025 . To achieve this would require over 400,000 natural gas HDVs to be produced for the European market in the next ten years. Volvo ${ }^{174}$ has presented an outline forecast of LNG truck sales of 1,000 in 2016 growing to 7,000 in 2020 by which time the total population of NGV HDVs would be around 28,000 . This suggests that the low case scenario is one seen most likely at least from the manufacturers' viewpoint.

Levels of penetration in the MDV market are likely to be closer to those used for the LCV market and these projections, assuming an average annual consumption of $24,000 \mathrm{~m}^{3}$ of natural gas and a fuel efficiency improvement rate of $2 \%$ pa are shown in Table 33.

Table 33: Projected market share in the medium commercial vehicle market for Europe (excluding Russia and Ukraine)

\begin{tabular}{|c|c|c|c|}
\hline Ultimate Market & Number of NGV MDVs & \multicolumn{2}{|c|}{ Projected Consumption in bcm } \\
\cline { 3 - 4 } share in 2025 (\%) & in 2025 & 2020 & 2025 \\
\hline 1 & 124,000 & 1.4 & 2.4 \\
\hline 2 & 244,000 & 2.6 & 4.7 \\
\hline 5 & 604,000 & 6.5 & 11.6 \\
\hline
\end{tabular}

Source: Author's analysis - see Appendix A for assumptions and methodology

Tables 32 and 33 exclude Russia and Ukraine as the market circumstances are substantially different from elsewhere in Europe. As noted above the Russian government is targeting a $30 \%$ share of the truck market for CNG by 2020 . Were this to be achieved and then continue 

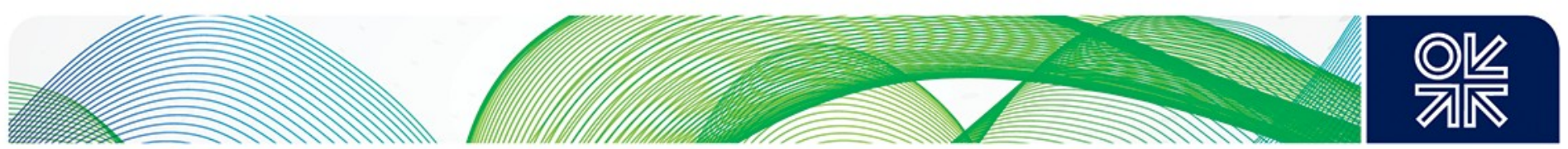

to grow to a $40 \%$ share in 2025 consumption in 2020 and 2025 could be in the region of 45 and $60 \mathrm{bcm}$ respectively. Consumption numbers in Ukraine are unlikely to grow very strongly at present due to the difficult market fundamentals facing the gas sector (although this might change if the recent accord with Russia on lower priced gas supplies prevails in the longer term).

All of the foregoing projections are for natural gas in total and do not distinguish between LNG and CNG. However it is likely that the medium and high case projections will be on the back of a substantial increase in LNG availability and usage and so can be assumed to account for around $80 \%$ of projected volumes. This split would be lower - say $50 \%$ - under the low case projection.

\subsubsection{Large commercial and freight vehicles - conclusions}

The large commercial vehicle market has a number of characteristics that make it an attractive prospect for NGVs. The financial and environmental benefits are such that they can be an attractive proposition for buyers and operators. Whilst there are some teething difficulties, operationally there do not appear to be any major drawbacks. For policy makers they represent a clear lower carbon option to diesel vehicles and also emit virtually no particulate matter. Manufacturers are starting to produce a wider range of NGV options though the market is still at a very early stage.

In addition to the issue of infrastructure, which is addressed in the next section, the other main obstacle is the dependence of the financial case on the continuing fiscal advantage given to natural gas over diesel. Uncertainty over this issue could remain a major inhibitor to growth in this sector.

\subsection{Infrastructure implications for road transport}

As already discussed an important dimension of the financial case for NGVs depends on the cost of refuelling and how this is recovered. In some markets where there is already a significant refuelling network these additional costs may not be huge though even Italy, which has extensive coverage, has a number of areas not covered including motorways.

Figure 25 compares the cost of filling with diesel/petrol against CNG based on European data. The figures are based on a survey of operators undertaken by Seidinger ${ }^{175}$ and include the direct costs such as equipment and fuel transport or grid connections (for the CNG option) and indirect costs such as land and buildings. It is clear that the refuelling aspect is by far the most significant. A typical petroleum retail site in Europe will have a throughput of 4 million litres/year and benchmark operating costs for a petroleum retail site are around $€ 200,000$. Given the likelihood of slow build-up of CNG sales co-location with existing facilities is clearly the most cost effective option though the cost of grid connections could still be a very significant additional item. 

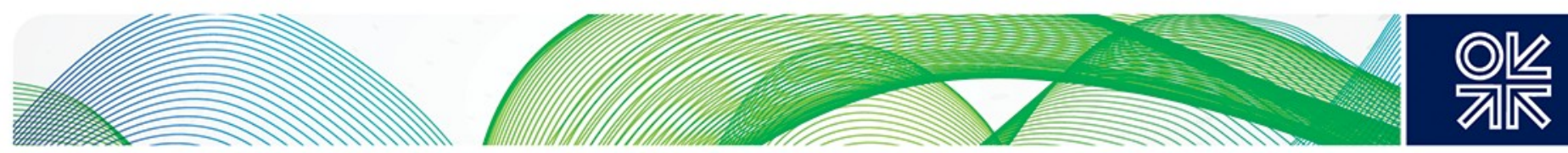

Figure 25: Fuelling cost comparison

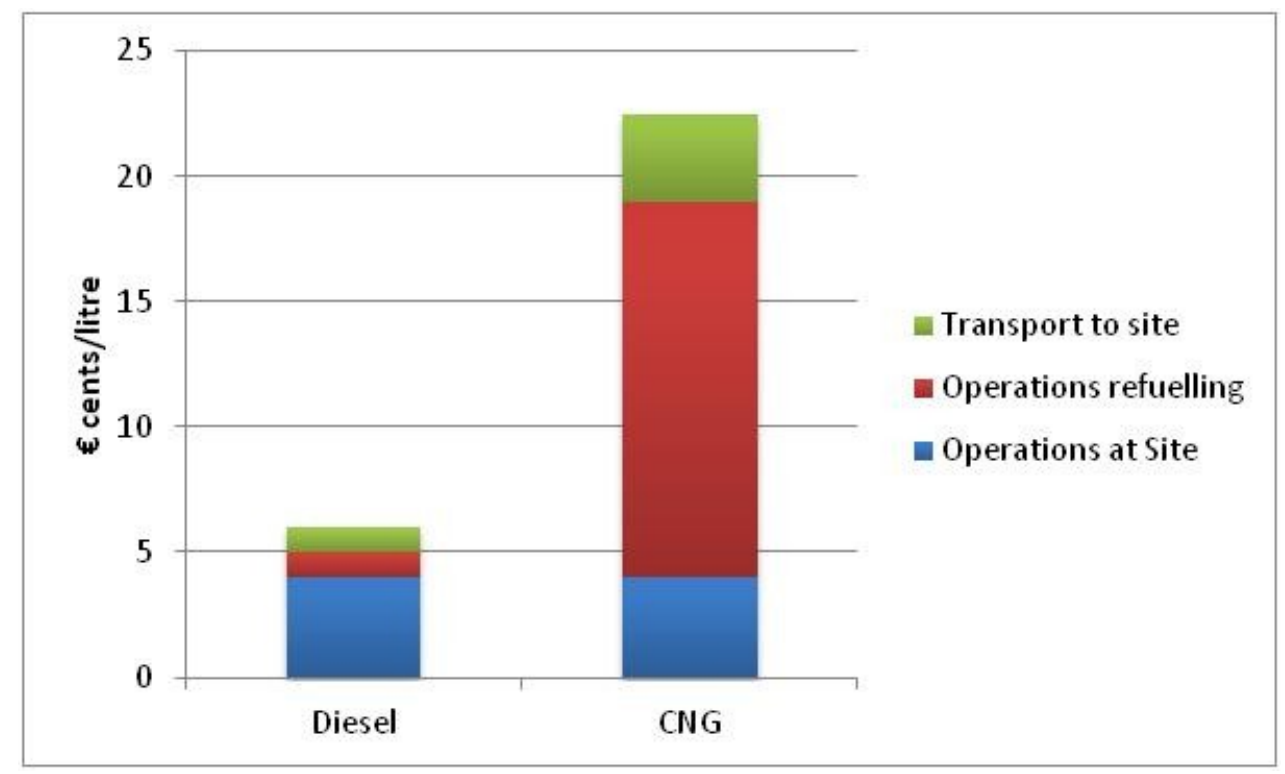

Source: Seidinger in IGU (2012)

Seidinger's analysis suggests that a dedicated CNG station would need an annual capacity of around 1 million $\mathrm{kg}$ of CNG (equivalent to around 1.46 million litres of diesel) and would need to achieve sales volumes of at least $30 \%$ of maximum sales capacity to be efficient.

A UK study ${ }^{176}$ puts diesel refuelling costs at around 3.2 pence/litre $(\$ 1.17 / \mathrm{mmbtu})$ and CNG at between 13 and $51 \mathrm{p} / \mathrm{kg}(\$ 3.25 / \mathrm{mmbtu}$ to $\$ 12.74 / \mathrm{mmbtu}$ respectively) and LNG costs at between 6 and $26 \mathrm{p} / \mathrm{kg}$ ( $\$ 1.5 / \mathrm{mmbtu}$ to $\$ 6.5 / \mathrm{mmbtu}$ respectively) - the range reflecting the much higher unit costs of low throughput stations. The details are shown in Table 34. These numbers seem to be in line with the EEGFTF numbers and have been confirmed by industry sources.

Table 34: NGV refuelling station costs

\begin{tabular}{|l|l|l|l|l|l|l|l|l|l|}
\hline & \multicolumn{4}{l|}{ CNG Station } & \multicolumn{2}{l|}{ LNG Station } & \multicolumn{2}{l|}{ L-CNG station } \\
\hline $\begin{array}{l}\text { Size } \\
(\mathrm{kg} / \mathrm{d})\end{array}$ & $\begin{array}{l}\text { Capex } \\
\AA^{\prime} 000\end{array}$ & $\begin{array}{l}\text { Capex } \\
\$ / \mathrm{mmbtu}\end{array}$ & $\begin{array}{l}\text { Opex } \\
\$ / \mathrm{mmbtu}\end{array}$ & $\begin{array}{l}\text { Capex } \\
£\end{array}$ & $\begin{array}{l}\text { Capex } \\
\$ / \mathrm{mmbtu}\end{array}$ & $\begin{array}{l}\text { Opex } \\
\$ / \mathrm{mmbtu}\end{array}$ & $\begin{array}{l}\text { Capex } \\
£^{\prime} 000\end{array}$ & $\begin{array}{l}\text { Capex } \\
\$ / \mathrm{mmbtu}\end{array}$ & $\begin{array}{l}\text { Opex } \\
\$ / \mathrm{mmbtu}\end{array}$ \\
\hline 500 & 160 & 8.6 & 7.7 & 73 & 3.5 & 4.8 & 150 & 7.4 & 7.7 \\
\hline 1000 & 200 & 5.4 & 4.5 & 93 & 2.2 & 2.9 & 200 & 4.8 & 4.5 \\
\hline 5000 & 350 & 2.2 & 2.6 & 260 & 1.3 & 1.0 & 500 & 2.6 & 3.8 \\
\hline 10000 & 700 & 1.9 & 2.2 & 350 & 1.9 & 1.0 & 800 & 1.9 & 2.9 \\
\hline
\end{tabular}

Source: Brightman et al (2011) converted from $\mathrm{p} / \mathrm{kg}$ to $\$ / \mathrm{mmbtu}$ at $£ 1=\$ 1.6$

The European Expert Group on Fuels for the Future ${ }^{177}$ (EEGFTF) argues that in order to establish a comprehensive network of NG refuelling stations there are 3 options:

\footnotetext{
${ }^{176}$ Brightman et al (2011)

${ }^{177}$ EEGFTF (2011b)
} 

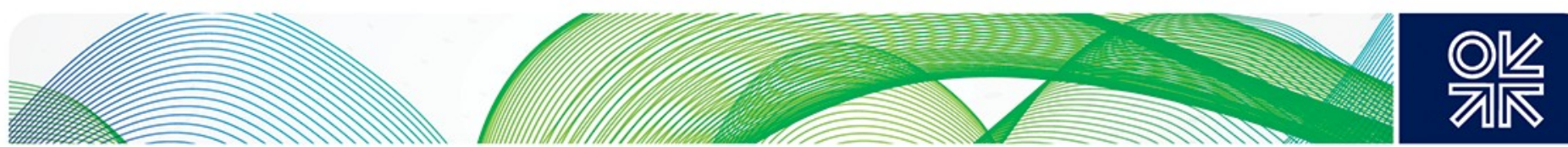

- European directive driven approach

- EU and the Member States acting in concert

- A national private-public partnership (PPP) approach within a supportive European framework

Some infrastructure providers and other stakeholders have suggested that it is already proving difficult to get the necessary national structures in place and that these should be developed in the first instance before seeking a broader EU approach.

The EEGFTF have recommended that given infrastructure investment costs of between $€ 300,000$ and $€ 400,000$ for public NG stations and $€ 1$ million for private depot-based facilities there is a case for creating a European infrastructure fund coupled with a Directive requiring Member States to establish a minimum refuelling infrastructure. They have suggested the following configurations:

- Car/LDV refuelling facilities would need to be located in around $10 \%$ of urban filling stations, and at $25 \%$ of those on motorways (with a maximum separation of $150 \mathrm{~km}$ ). Gaps in coverage (including remote areas) could be augmented by home refuelling, where a small compressor unit is linked to the domestic gas connection. However in many European countries remote locations are often not served by a gas distribution grid.

- For HDVs the infrastructure requirements will depend on whether the vehicles are primarily used for local or long distance haulage. For the latter L-CNG filling stations, able to provide both CNG for LDVs and LNG for HDVs should be located every 400 $\mathrm{km}$ along major European motorways. Urban coverage would be based around vehicle fleets such as buses and refuse trucks. The EEGFTF has suggested that European cities should aim for $50 \%$ fleets to be NG-fuelled.

This has led to the development of the EU's Clean Fuel Strategy ${ }^{178}$ which has the following metrics:

- CNG stations within $150 \mathrm{~km}$ by 2020

- LNG stations within $400 \mathrm{~km}$ by 2020

These metrics have been used by the EC to develop an estimate of the total investment costs and this is shown in Table 35. It is not clear how these sums might ultimately be recovered and there is the danger that an over-extension of the network coupled with front loading of investment costs onto users could significantly increase direct costs of switching to natural gas.

Table 35: Road vehicle refuelling requirements

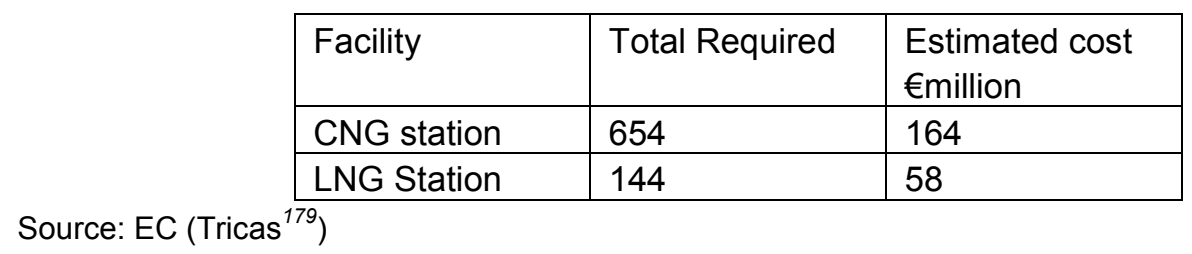

It has already been noted that for long haul operators the availability of a comprehensive network of LNG refuelling stations will be vital. It is also unlikely that liquefaction of grid gas will be an economic option in the early stages of development so an effective cryogenic

\footnotetext{
${ }^{178}$ http://europa.eu/rapid/press-release_IP-13-40_en.htm

${ }^{179}$ Presentation to Natural Gas Vehicle Conference Amsterdam(25-26th Nov 2013)
} 

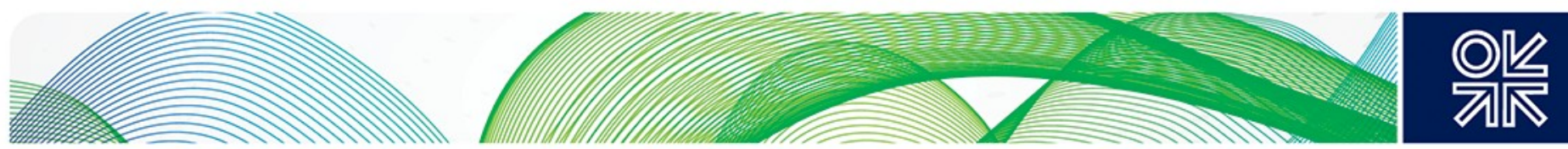

supply chain emanating from existing LNG import terminals will need to be established. This supply chain already exists to some extent in some countries - for example in Spain, France and the UK LNG is transported by road to supply remote gas networks or off-grid industrial consumers. In the case of the UK LNG is shipped to one network over $600 \mathrm{~km}$ away in this manner.

There are a range of companies involved in providing LNG refuelling services at present. They include oil and gas companies such as Shell and GDF SUEZ, industrial gas companies such as Linde/BOC and independents such as Chive in the UK and Ballast Nedam's LNG24 subsidiary in The Netherlands ${ }^{180}$. Some of the oil and gas companies are aiming to provide customers with access to refuelling stations and a guaranteed discount for the price of LNG to the prevailing diesel price in return for a term contract. This contract based approach may make easier to build up the network as investments can to some extent be underwritten. Furthermore as Table 34 demonstrates front loading the cost of refuelling at low throughput facilities would be very expensive for users.

An important consideration for LNG-fuelled road transport is the amount of LNG import capacity available in Europe, its location, the extent to which it is utilised and the presence (if any) of road loading facilities. Table 36 shows the present and planned level of LNG refuelling sites together with the level of LNG import capacity. Figure 26 shows the location of existing and planned terminals in Europe. In addition to these terminals there are a limited number of LNG storage facilities that have traditionally been used for peak shaving supply but can also provide a source of road-borne LNG. An example of this is the Avonmouth plant in the UK though this plant has been operating since 1978 and is expected to close before 2018 .

It is notable that the existing refuelling stations generally occur in countries that are existing LNG importers and so have terminal facilities. The extension of the network beyond these countries into central Europe will clearly be crucial and it is likely that waterborne transport of LNG will be required in addition to road vehicles.

Table 36: Existing and planned LNG L-CNG vehicle refuelling stations

\begin{tabular}{|l|c|c|l|l|l|}
\hline \multirow{2}{*}{ Country } & \multicolumn{2}{|c|}{ Existing } & Planned & $\begin{array}{l}\text { LNG Import } \\
\text { capacity } \\
\text { (bcm/a) }\end{array}$ & $\begin{array}{l}\text { LNG Storage } \\
\text { capacity (BCM } \\
\text { NG) }\end{array}$ \\
\cline { 2 - 6 } & LNG & L-CNG & & & \\
\hline Germany & 0 & 0 & 1 & 0 & 0 \\
\hline France & 0 & 0 & 3 & 24 & 0.5 \\
\hline Italy & 0 & 7 & 2 & 11 & 0.2 \\
\hline Netherlands & 7 & 1 & $15-20$ & $21^{*}$ & $0.54^{*}$ \\
\hline Spain & 12 & 12 & 1 & 60 & 1.95 \\
\hline Sweden & 9 & 4 & 1 & 0.7 & 0.02 \\
\hline United Kingdom & 13 & 9 & 1 & 51 & 1.22 \\
\hline
\end{tabular}

Source: Refuelling stations: Author's estimates based on figures in IGU (2012) and from Blue Corridors and NGVA, LNG import data from GLE Investment database

*Includes Belgium (Zeebrugge) 

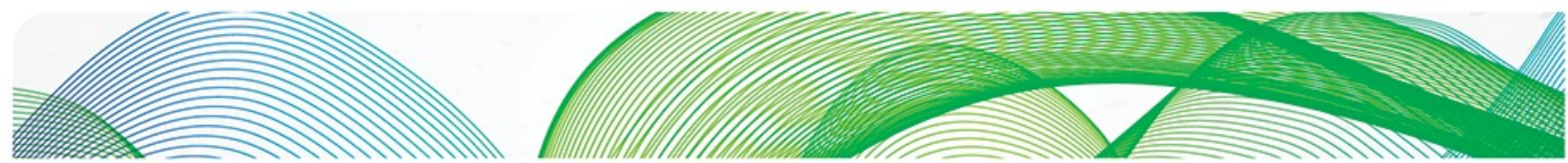

Figure 26: Existing and planned LNG import terminals in Europe

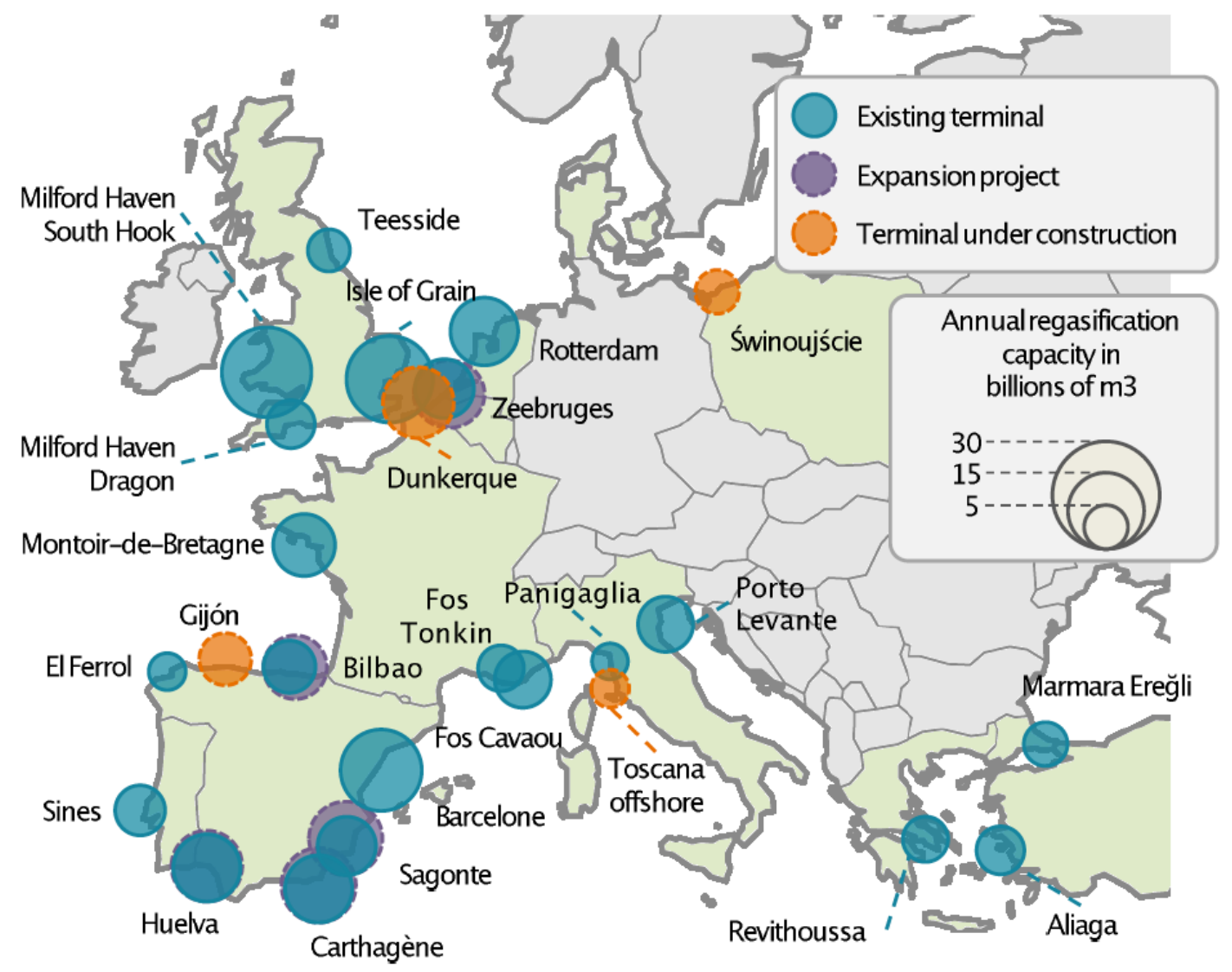

Source: Gas in Focus, http://www.gasinfocus.com/wp-content/uploads/2013/03/INFRA EN 6.pdf

Not all of the LNG import terminals have road loading facilities though these can normally be installed relatively quickly and easily. For example National Grid approved the installation of such facilities at the Grain terminal in November 2013 and these should be on stream by 2015. This facility will comprise 2 bays and will be able to handle up to 36 tankers per day of up to $40 \mathrm{~m}^{3}$ capacity ${ }^{181}$.

In Spain Enagas operates road loading facilities at the Barcelona, Cartagena and Huelva terminals each capable of handling 50 trucks per day ${ }^{182}$ and Fluxys has a similar, albeit smaller, facility at its Zeebrugge terminal. One of the issues relating to LNG truck loading is how and over what period capacity is booked and allocated and how congestion is dealt with. For example Fluxys has developed a detailed access code for truck loading at Zeebrugge to deal with these issues ${ }^{183}$.

There are therefore indications that the LNG refuelling network is slowly developing in line with increased demand. There is less evidence that CNG facilities are expanding and where

\footnotetext{
${ }_{182}^{181}$ Ed Carter (NG) speaking at Natural Gas Vehicle Conference Amsterdam(25-26th Nov 2013)

http://www.enagas.es/cs/Satellite?c=Page \&cid=1146232320009\&language=en\&pagename=ENAGAS\%2FPage $\% 2 F$ ENAG_pintarContenidoFinal\&site=ENAGAS
}

http://www.fluxys.com/belgium/en/Services/LNGTerminalling/TruckLoading/ /media/Files/Services/LNG\%20Terminal ling/TruckLoading/LNG\%20Access\%20Code\%20Truck\%20Loading\%20EN.ashx 

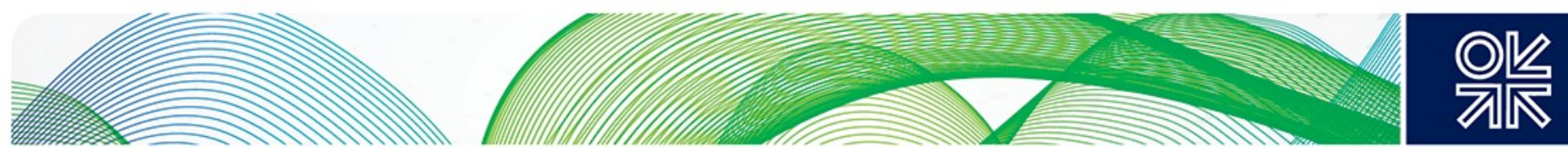

these need grid connections the costs can sometimes be prohibitive. LNG refuelling facilities have the advantage of being able to be built relatively quickly and by varying storage configurations they can be more effectively "right-sized". Furthermore the equipment can be dismantled and relocated elsewhere if required. This inherent flexibility suggests that extending the LNG network and using these sites to provide CNG facilities where required may be the best way of building capacity at this stage of the market's development.

\subsection{Marine and inland waterways}

Globally there are around 55,000 ships in operation ${ }^{184}$ and according to the EC around 10,000 ships are utilised for European short sea shipping. Most of these vessels burn either fuel oil or marine diesel though according to Poten 300 LNG transport vessels already consume some $12 \mathrm{mt} /$ year of $\mathrm{LNG}^{185}$.

Figure 27 shows the key external factors and stakeholder map for marine and IWT. The main drivers influencing the use of natural gas in this sector are probably financial and legislative with the later having a particular impact as described below.

Figure 27: Key external factors and stakeholder map for marine and inland waterway vessels

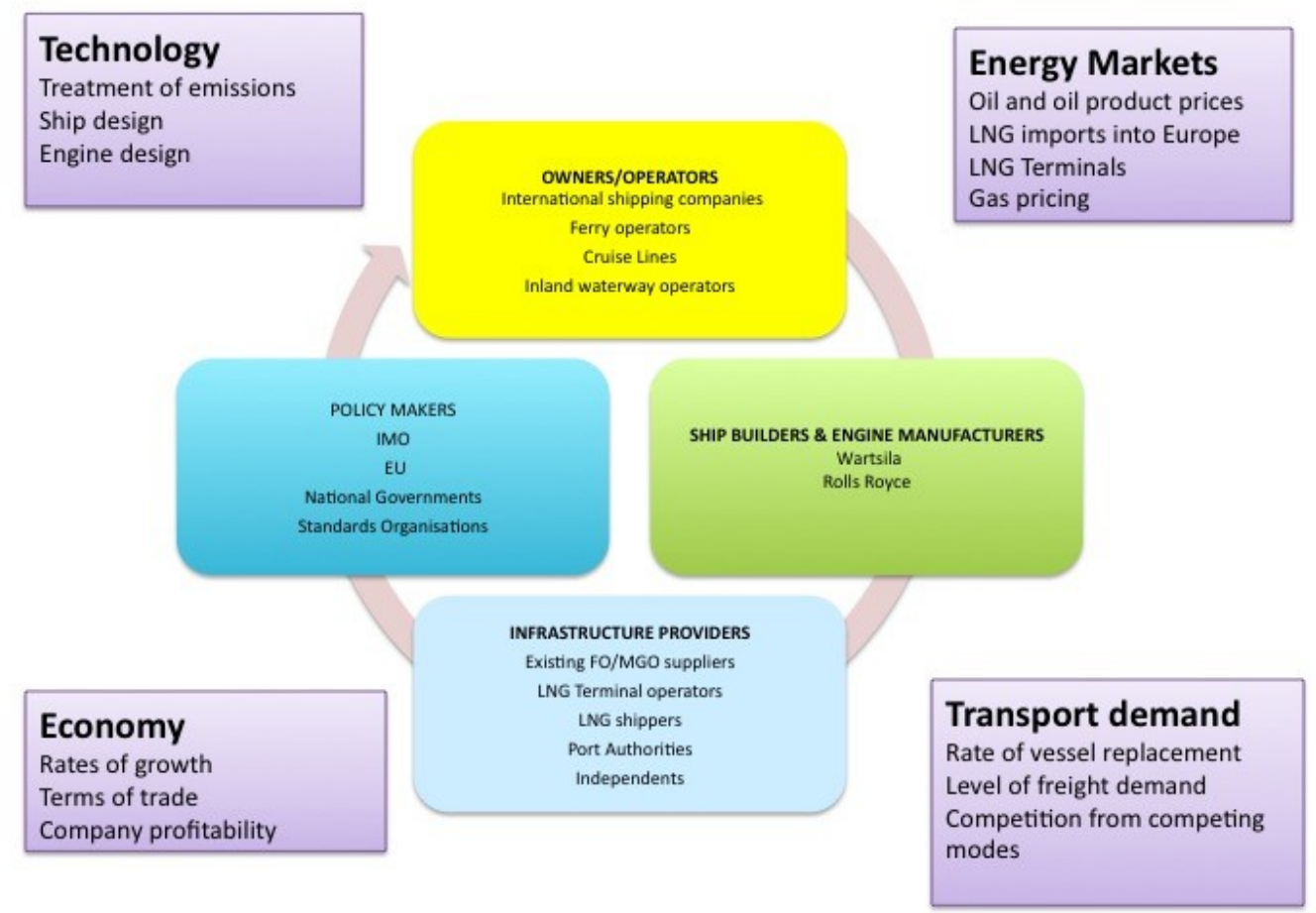

Source: Author based on Batterbee \&Lidstone (2013)

${ }^{184}$ IMO (2012)
${ }^{185}$ Poten presentation at LNG 17, April 2013 

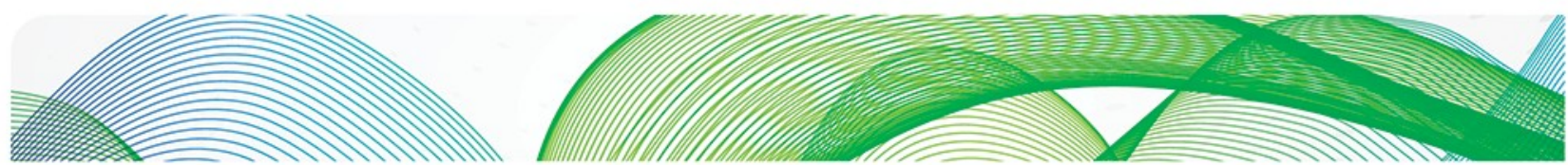

\subsubsection{Owners/operators}

Ships are long life investments compared to road vehicles - typically operating for between 20 and 30 years. The rate of fleet turnover is therefore slower and the introduction of new technology can be correspondingly lengthy. On the other hand retrofit of existing ships to burn LNG is a more viable option than for road vehicles. The two most important factors driving the implementation of new technologies measured by DNV (2012) is to comply with regulations and improve cost effectiveness through improved fuel efficiency.

The main types of operators within the EU can be split between those spending most of their time in EU waters - these will include ferries, inland barges, coastal bulk carriers and tankers - and those ocean-going vessels that pass through EU waters.

This analysis focuses on the former group as they are most directly affected by the MARPOL legislation described in 5.6.4. requiring a reduction in emissions from vessels operating in special environment control areas (SECA).

In broad terms there are three options open to operators who are presently burning HFO in their vessels in order to deal with these new restrictions:

- Install scrubbers which remove $\mathrm{SO}_{2}$ from the exhaust gas (this solution is not yet proven and there are issues over how the sulphur sludge is handled)

- Burn costlier MGO (marine gas oil)

- Convert to LNG either as a retrofit or through purchasing a new vessel - more space is required for gas storage and of course the supply chain has to be developed

Table 37 shows the PWC calculation of full life costs of an LNG ship versus the alternatives. The additional investment for an LNG solution can be recovered in between 3 and 4 years according to the PWC analysis ${ }^{186}$. According to DNV (2012) $25 \%$ of ship-owners have a payback horizon 0 to 2 years and $50 \%$ one of 3 to 5 years.

Table 37: Comparison of alternative marine fuelling options for 9,000 DWT vessel

\begin{tabular}{|l|l|l|l|l|l|}
\hline $\begin{array}{l}\text { Reduction in } \\
\text { cost compared } \\
\text { with HFO }\end{array}$ & SOx & Nox & CO2 & $\begin{array}{l}\text { Life } \\
\text { cycle } \\
\text { cost } \\
\in m^{187}\end{array}$ & $\begin{array}{l}\text { Equivalent cost in } \\
\$ / \text { tonne }\end{array}$ \\
\hline HFO as is & - & - & - & 15.2 & \\
\hline $\begin{array}{l}\text { HFO + } \\
\text { scrubber }\end{array}$ & $-90 \%$ & $0 \%$ & +0.5 to $1 \%$ & 24.7 & 950 \\
\hline MGO & $-90 \%$ & $0 \%$ & $0 \%$ & 26.0 & 1300 \\
\hline LNG & $-100 \%$ & $-90 \%$ & -20 to $-25 \%$ & 19.3 & $\begin{array}{l}600(+400 \text { to cover ship } \\
\text { and port costs })=1,000\end{array}$ \\
\hline
\end{tabular}

Source: PWC 2013, EC 2013

Analysis by $\mathrm{BIMCO}^{189}$ demonstrates that the economics for ship owners is a function of the spread between the different fuels, the remaining vessel life and the expected amount of time

\footnotetext{
${ }^{186}$ PWC (2013)

${ }^{187}$ Based on 9,000 ton DWT vessel, 8,000 KW engine consuming 5,200 tons/year of HFO

${ }^{188}$ From Citi (2013)
} 

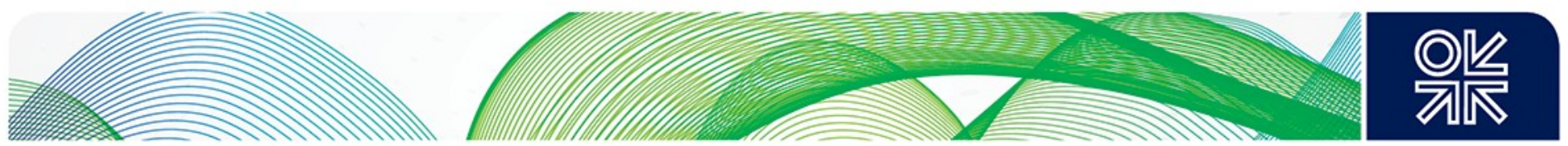

the vessel is expected to spend in an ECA. So for example a spread between HFO and MGO of $\$ 250 / \mathrm{mt}$ would mean that the installation of a scrubber could be justified if the vessel expected to spend more than $25 \%$ of its time in an ECA. If a vessel is permanently operating in an ECA the required spread falls to $\$ 60 / \mathrm{mt}$. Using the prevailing spread of $\$ 258$ (as at 25.4.13) BIMCO calculates that a vessel with a remaining commercial life of five years would need to spend over $70 \%$ of its time in an ECA to make installation worthwhile - this falls to $25 \%$ if the remaining commercial life is extended to 14 years.

Total SA ${ }^{190}$ has analysed the economics of the LNG option with the alternatives of HFO plus scrubbers and burning MGO by calculating the minimum discount required for LNG versus competing fuels to achieve a 5-6 year payback. The analysis was done for a range of vessel types and the results were as follows:

- For LNG versus HFO plus scrubbers the minimum discount required for LNG to HFO is at or below $\$ 2 / \mathrm{mmbtu}$ for most vessel types (tankers, container ships, ferries and most cargo vessels) with small general cargo and medium bulk carriers requiring a discount of just above $\$ 3 / \mathrm{mmbtu}$ and nearly $\$ 5 / \mathrm{mmbtu}$ for large bulk carriers

- For LNG versus burning MGO the minimum discount required for LNG to MGO is between $\$ 2 / \mathrm{mmbtu}$ and $\$ 4 / \mathrm{mmbtu}$ for most vessel types (tankers, container ships, ferries and most cargo vessels) with small general cargo and medium and large bulk carriers requiring a discount of around $\$ 6 / \mathrm{mmbtu}$.

Total concludes that LNG is the most economical solution in all cases and all regions.

DNV calculate that LNG becomes cost effective for vessels that spend more than $30 \%$ of their time in an SECA ${ }^{191}$.

There has been progress towards LNG usage with ship operators in the Baltic region. There are a number of refuelling points and ship operators are starting to employ LNG fuelled vessels. For example:

- Shell subsidiary Gasnor owns and operates 3 LNG production plants in Norway and supplies some 30 ships with $\mathrm{LNG}^{192}$

- Viking Line are operating an LNG-fuelled ferry from Stockholm to Turku ${ }^{193}$

- Fjord line operates two LNG ferries between Denmark, and Norway. Until recently LNG refuelling could only be done in Denmark as Norwegian regulations prohibited refuelling when the vessel had passengers on board - this necessitated the transfer of LNG from Stavanger to Denmark for refuelling. It is understood this has now been resolved and refuelling can take place from tank cars in Norway ${ }^{194}$

- NSK operates what is claimed to be the world's first gas-powered cargo vessel in Northern Norway ${ }^{195}$

Inland waterway transport (IWT) operators (of whom there are around 10,000 in Europe) tend to operate much older vessels. The average life span of a Rhine bulk carrier is around 50 years $^{196}$, this and the lack of incentive to improve environmental performance means that the uptake of new technology is very slow. Analysis by Panteia (2013) suggests that a payback

\footnotetext{
${ }^{189}$ https://www.bimco.org/en/Reports/Market_Analysis/2013/0424_ECAStory.aspx

190 Semolinos (2013)

191 DNV $(20120$

192 http://gasnor.betatest.no/wp-content/uploads/2012/11/Annual-Report-20112.pdf

${ }^{193}$ http://www.vikingline.com/en/Investors-and-the-Group/Safety--environment/Environment/Viking-Grace/

${ }^{194} \mathrm{http}$ ://www.aftenbladet.no/energi/LNG-trobbel-lost-for-Fjord-Line-3241069.html\#.UqsvK2QbB90 (in Norwegian)

195 http://www.rolls-royce.com/sustainability/casestudies/Ing_fuelled_engines.jsp

${ }^{196}$ Europia (2013)
} 

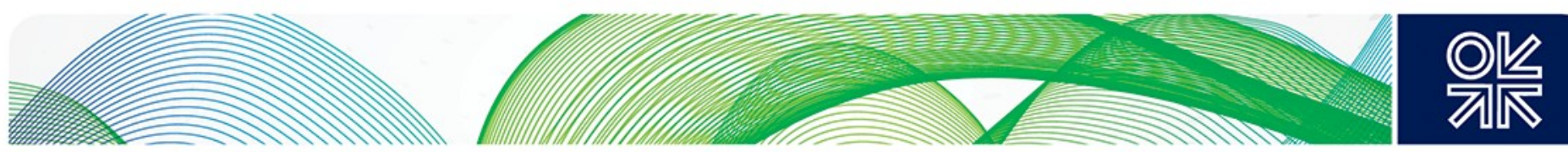

for a new LNG-fuelled vessel operating for 5,000 hours/year would be around 5 years. Some progress is being made in this sector and Shell charters two 100\% LNG-fuelled barges on the Rhine ${ }^{197}$.

\subsubsection{Ship builders and engine manufacturers}

Many marine engine manufacturers are developing LNG-fuelled versions that are either spark ignited gas only engines or dual-fuelled engines that can run on both LNG and diesel though methane slip can be a problem with some dual-fuelled engines ${ }^{198}$. The main manufacturers in Europe are Rolls Royce and Wartsila. Rolls Royce Bergen LNG engines are being used on Norwegian ferries and the company claims to have achieved savings in maintenance costs of 5 to $10 \%$ annually ${ }^{199}$.

In IWT the small size of the sector has meant that engine manufacturers have not focussed on providing improved performance. The main obstacles to converting existing vessels to natural gas would be the additional fuel storage requirements reducing cargo capacity ${ }^{200}$.

\subsubsection{Infrastructure providers}

The key players in infrastructure provision are LNG shippers/suppliers, LNG terminal operators and port authorities and a key determinant is the availability of suitable LNG terminals, storage and reloading facilities. Figure 26 shows the disposition of import terminals in Europe. According to the GLE investment database ${ }^{201}$ present capacity is $199 \mathrm{bcma}$ and this could grow to $355 \mathrm{bcm} / \mathrm{a}$ by 2020 . However the current LNG supply chain is configured for the handling of large (i.e. greater than $150,000 \mathrm{~m}^{3}$ ) LNG carriers with the LNG being regasified in receiving terminals for supply through gas transmission systems.

It will therefore be necessary to develop a smaller scale infrastructure to supply ships - this would include jetties capable of handling smaller vessels and facilities and procedures to enable ship-to-ship transfer for bunkering purposes. Such a network is already in place in Norway and this is planned to extend coverage to the rest of the North Sea/Baltic area as shown in Figure 28 - note that Rotterdam, Zeebrugge and Teesside have existing LNG import facilities (though Teesside has no storage) and LNG terminals are under construction at Dunkerque and Swinoujscie. A critical question is whether port authorities, ship owners or bunker retailers or perhaps a combination of all three will make the investment.

\footnotetext{
${ }^{197} \mathrm{~L}$ Wetemans presentation at Paris conference

${ }^{198}$ DNV (2012)

199 http://www.rolls-royce.com/sustainability/casestudies/Ing_fuelled_engines.jsp

${ }^{200}$ Panteia (2013)

${ }^{201}$ http://www.gie.eu.com/download/maps/2013/GLE\%20Investment\%20Database \%2020052022 July $\% 202013$ final.xlsx
} 

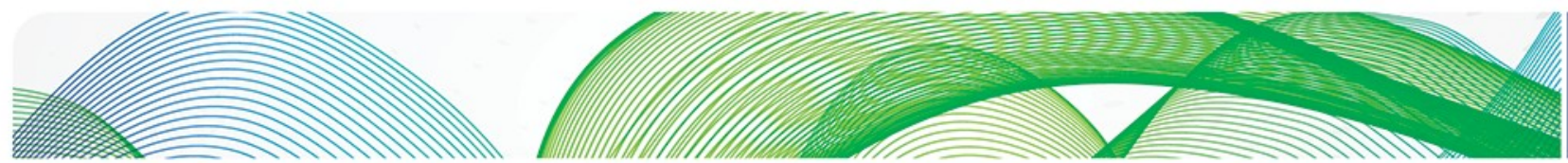

Figure 28: Existing and planned LNG bunkering facilities in Europe

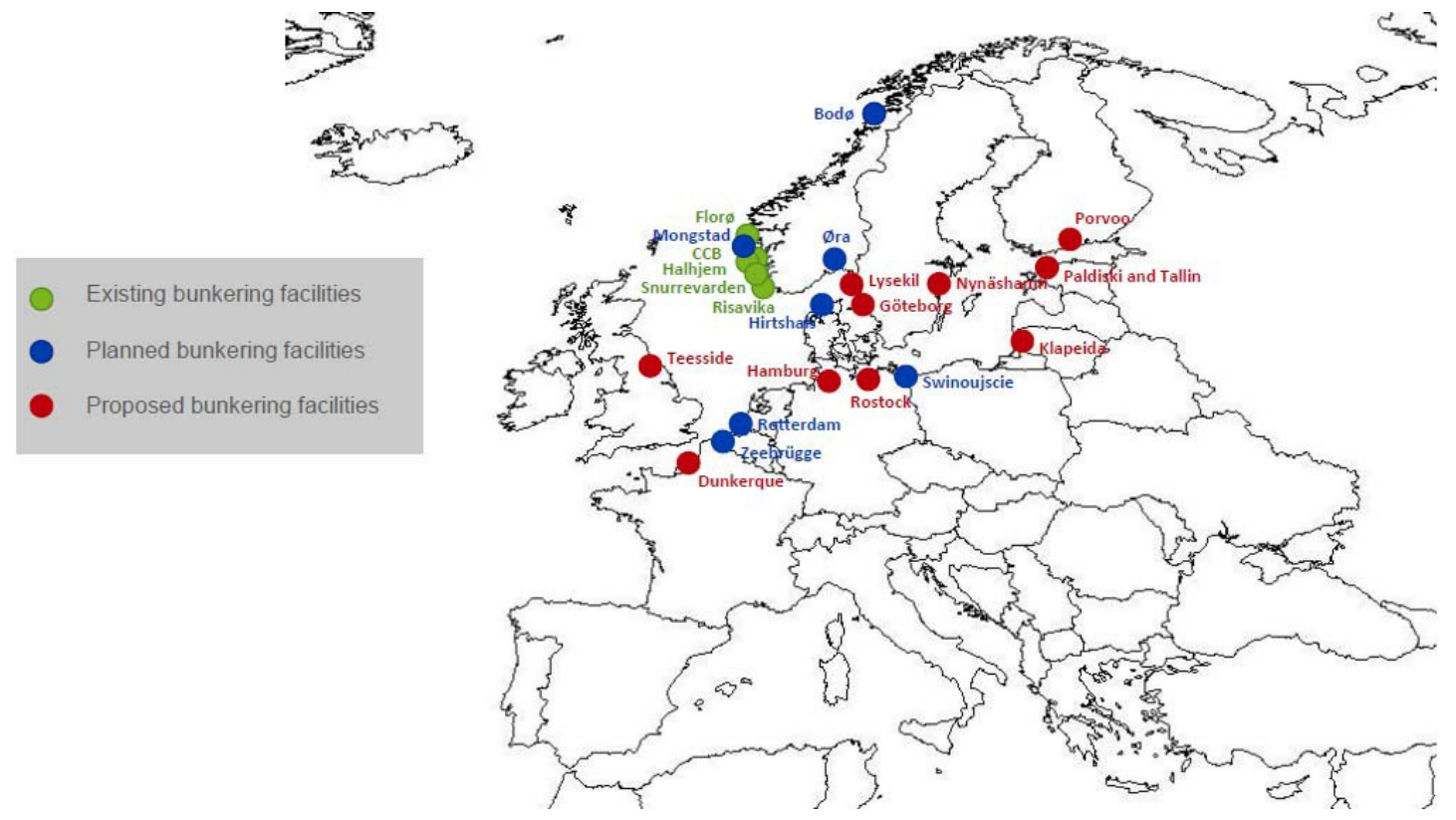

Source: DNV

The Danish Maritime Authority has undertaken a major study of LNG infrastructure and deployment in ships in the Baltic region. They have forecast demand (see below) and calculated the infrastructure implications ${ }^{202}$.

In terms of costs DMA have examined a range of cases and two examples are shown in Table 38

Table 38: Costs of marine LNG refuelling options

\begin{tabular}{|l|c|c|}
\hline \multirow{2}{*}{ Cost element €million } & \multicolumn{2}{|c|}{ Throughput '000 $\mathrm{m}^{3} / \mathrm{a}$} \\
\cline { 2 - 3 } & 204 & $343+20000 \mathrm{~m}^{3}$ tank \\
\hline Capital & 69 & 137 \\
\hline Of which vessels & 32 & 60 \\
\hline Annual opex & 10 & 17 \\
\hline
\end{tabular}

Source: Danish Maritime Authority (2011)

The precise infrastructure implications will depend on a range of economic, technical and logistical factors and include:

- Location, characteristics and pace of conversion/new build ships

- Port considerations - physical attributes, safety requirements, environmental restrictions etc

- Local incentives 

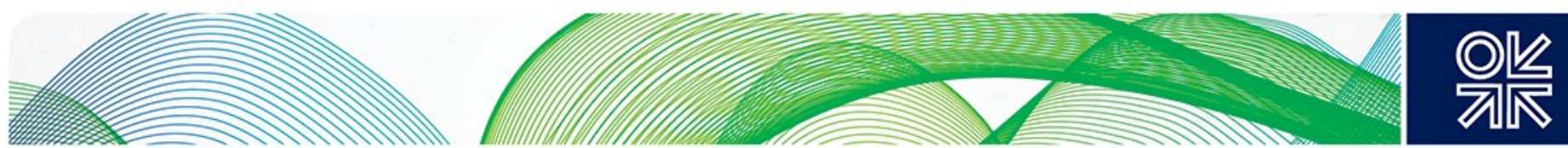

DMA analysis suggests breakeven throughputs will range from 100,000 tonnes/year to over 200,000 tonnes for larger facilities. To have sufficient infrastructure to meet the forecast central case demand would require an estimated 9 medium size terminals and a further 23 small terminals plus 24 bunker vessels of varying dimensions. There would inevitably be some under utilisation during the early stages of the programme and the addition of some land-based demand (either transport or other purposes) would be required to underpin the business case.

Total has calculated the logistics costs for small and large ports and how these vary with increasing throughput - shown in Figure 29. The cost of refuelling by road tanker is fixed at around $\$ 2.2 / \mathrm{mmbtu}$ so below $0.3 \mathrm{mtpa}$ of LNG this is the most economical option. Above this level (equivalent to 3 or 4 small to medium ports) barge supply becomes more economical. Total suggests that investment in major infrastructure is justified once throughput reaches 0.75 to $1 \mathrm{mtpa}$ of LNG and calculates that refuelling costs fall below $\$ 1 / \mathrm{mmbtu}$ at throughputs of around $1.75 \mathrm{mtpa}$.

Figure 29: Marine LNG refuelling costs $v$ throughput

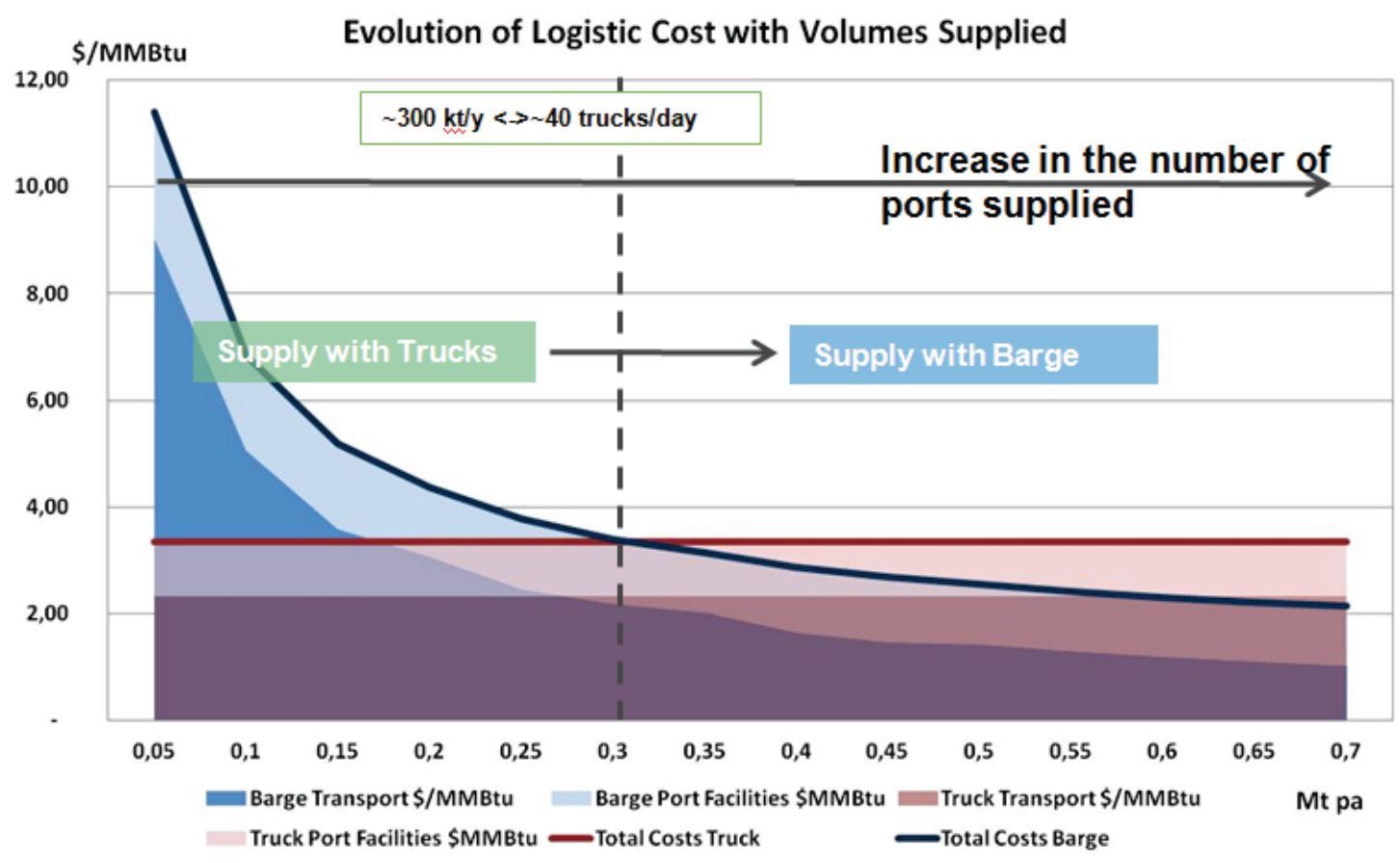

Source: Semolinas (2013)

The Clean Power for Transport (CPT) Package awarded $€ 78$ million in July 2013 to boost landing capacity and expand the logistics infrastructure along the Rhine and Danube rivers to help develop LNG supplies. In addition the ports of Gothenburg in Sweden and Rotterdam have received funds to build a break-bulk bunker facility for LNG. ${ }^{203}$ The eventual target of the CPT directive is that all main ports have publicly accessible LNG refuelling points by 31 

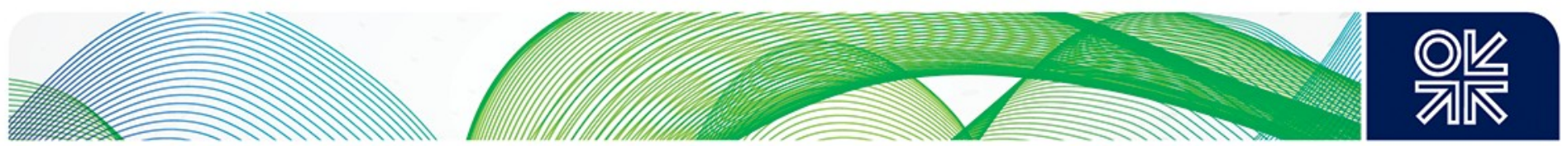

December 2020 at the latest. However the cost of this programme is estimated at $€ 2,085$ million $^{204}$ and it is not clear if a full business case has been made.

As with road-based LNG refuelling facilities it is possible to scale marine LNG facilities as throughput increases. This should mitigate the risk of over investment though some risk will be unavoidable where ports decide to invest in a major upgrade in capacity.

\subsubsection{Policy makers}

In marine the most important policy development is that enshrined within the IMO's International Convention for the Prevention of Pollution from Ships known as MARPOL ${ }^{205}$. MARPOL Annex $\mathrm{VI}$ sets limits on sulphur oxide $\left(\mathrm{SO}_{\mathrm{x}}\right)$ and nitrogen oxide $\left(\mathrm{NO}_{\mathrm{x}}\right)$ emissions from ship exhausts, with more stringent standards in designated special emission control areas (SECAs). This means in practice that the level of sulphur emissions was capped at $3.5 \%$ (from $4.5 \%$ ) for all shipping from 1 January 2012 with a view to reducing this level to $0.50 \%$, with effect from 1 January 2020 , subject to a feasibility review to be completed no later than 2018 which may defer the switch to 2025.

The limits applicable in SECAs for $\mathrm{SO}_{\mathrm{x}}$ and particulate matter were reduced to $1.00 \%$, beginning on 1 July 2010 (from the original $1.50 \%$ ) being further reduced to $0.10 \%$, effective from 1 January 2015. ${ }^{206}$ The European emission control areas encompass the Baltic Sea, the North Sea and the English Channel ${ }^{207}$. The industry and EU agreed in September 2012 that the $3.5 \%$ limit would be reduced outside the SECAs to $0.5 \%$ even if the IMO review defers this lower limit to a later date.

According to the EC around 10,000 ships are utilised for European Short Sea Shipping of which $50 \%$ spend in excess of $50 \%$ in SECAs. The moves to limit high sulphur fuels could therefore have a significant impact on sea shipping.

Inland waterway transport (IWT) also plays an important role within Europe and whilst this was always seen as environmentally much more preferable to road transport, improvements in the performance of the latter has meant that the gap is closing. A report by Panteia (2013) for the EC notes that unlike road haulage, emission standards for new engines are much less stringent and the engines on inland barges have a much longer average lifetime. This means that certain vessel types already have higher emission levels per tonne kilometre than road transport. $\mathrm{NO}_{x}$ and particulate emissions are a major concern. The CPT initiative includes provisions for investment in LNG fuelling facilities for IWT.

Another important initiative being introduced by the IMO is the energy efficiency design index (EEDI) requirements that stipulate reductions in $\mathrm{CO}_{2}$ emissions from new build vessels ${ }^{208}$. This could accelerate the pace of vessel replacement and so further encourage the switch to natural gas.

\footnotetext{
204 Tricas speaking at Natural Gas Vehicle Conference Amsterdam(25-26th Nov 2013) based on 8 refuelling points in Germany with a cost of $€ 120$ million

${ }^{205}$ See http://www.imo.org/About/Conventions/ListOfConventions/Pages/International-Convention-for-the-Preventionof-Pollution-from-Ships-(MARPOL).aspx

${ }^{206} \mathrm{http}$ ///www.imo.org/OurWork/Environment/PollutionPrevention/AirPollution/Pages/Air-Pollution.aspx

207 See

http://www.imo.org/OurWork/Environment/PollutionPrevention/SpecialAreasUnderMARPOL/Pages/Default.aspx

${ }^{08}$ http://www.imo.org/MediaCentre/HotTopics/GHG/Pages/EEDI.aspx
} 

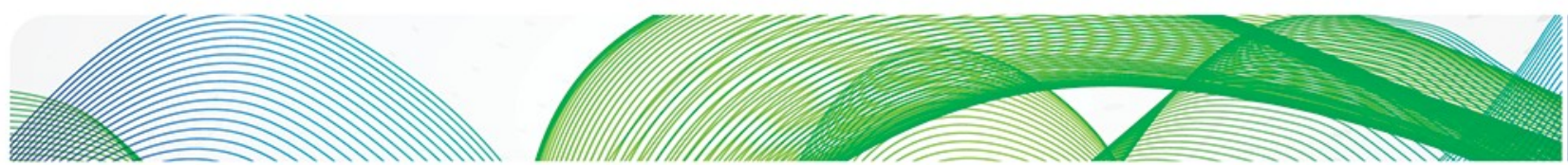

\subsubsection{Prospects for growth}

The Danish Maritime Agency estimates that in 2010 approximately 14,000 vessels entered the European SECA of which 2,200 vessels were present all of the time. Total consumption by these ships during the time they are in the SECA is estimated at $12 \mathrm{mtpa}^{209}$ growing to more than $17 \mathrm{mtpa}$ by 2030 assuming a fleet growth rate of $2 \% / y e a r$. Overall consumption in marine bunkers for the EU is $50 \mathrm{mtpa}$.

The approach adopted by this study to project possible demand in the road sector based on vehicle replacement rates is not appropriate in marine as the level of retrofitting is expected to be much higher. The projections are based instead on the same market share levels projected for large commercial road transport with the lower case increased from $2 \%$ to $5 \%$. It is assumed that the present level of consumption in this sector will remain broadly static with any growth in fleet size and activity being counter-balanced by fuel efficiency improvements. In IWT the 10,000 freight vessels account for around $90 \%$ of fuel consumption and this is estimated to be 5.5 mtoe based on EU statistics - the total European market is therefore equivalent to around $62 \mathrm{bcm}$. The projections are shown in Table 39

Table 39: Projected gas consumption in marine and IWT sector

\begin{tabular}{|c|c|c|}
\hline Ultimate Market & \multicolumn{2}{|c|}{ Projected Consumption in bcm } \\
\cline { 2 - 3 } share in 2025 (\%) & 2020 & 2025 \\
\hline 5 & 1.5 & 3.1 \\
\hline 10 & 3.1 & 6.2 \\
\hline 20 & 6.2 & 12.3 \\
\hline
\end{tabular}

Alternative forecasts for natural gas usage in the marine and IWT sector are shown in the following section.

\subsection{Summary of projections and comparison with alternative forecasts}

This section summarises the main external forecasts of gas demand in transportation identified by the study and compares these with the projections from the foregoing analysis.

The research has identified a number of forecasts of natural gas in transportation usage. These vary in geographic and sectoral coverage so may not always be directly comparable with each other.

In global terms the main forecasts for road transport are:

- The IEA ${ }^{210}$ assumes a generally supportive policy environment under the New Policies Scenario in its 2013 WEO projections with overall global transport demand for gas doubling to $225 \mathrm{bcm}$ in $2035^{211}$ to account for $5.6 \%$ of total transport energy demand (up from $3.8 \%$ in 2012). The share of gas in road transport is expected to 

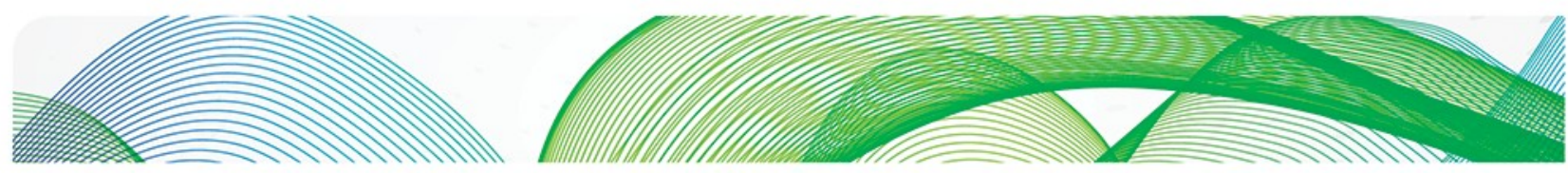

be $4.8 \%$ by 2035 (up from the previous year's forecast of $4 \%$ ) with consumption concentrated in China $(35 \mathrm{bcm})$ and the USA $(25 \mathrm{bcm})$. The breakdown of new vehicle sales by 2035 is $75 \%$ conventional, hybrids $20 \%$, NGVs $3 \%$, BEVs and plugin hybrids $4 \%$

- The IGU is more bullish, forecasting that by 2020 the methane share of the motor fuels market will be $11 \%$ in Asia, $12 \%$ in the Americas and $14 \%$ in Europe. World gas consumption in transport is expected to increase from $20 \mathrm{bcm}$ in 2010 up to 40 $45 \mathrm{bcm}$ in 2030.

- Shell has presented some projections ${ }^{212}$ for LNG use in road (and marine - see below) indicating a $10 \%$ to $20 \%$ share for natural gas in the heavy duty transportation segments.

- BP has developed a set of global forecasts for gas in transportation (i.e. including marine) to 2035. The company expects demand growth for gas to be fastest in transport $\left(7.3 \%\right.$ p.a.) but notes that this is from a small base ${ }^{213}$.

- Citi has developed 3 Scenarios based on the USA; a base case whereby $50 \%$ of all new HDVs are gas-powered plus low and high cases with penetration levels of $10 \%$ penetration and ultimately $100 \%$ respectively, these are combined with forecasts of marine demand based on the Lloyds Register report (2012).

These forecasts are summarised in Table 40 converted to bcm of natural gas where appropriate.

Table 40: Global demand for gas in road transportation - external forecasts

\begin{tabular}{|l|c|c|c|}
\hline Forecast $(\mathrm{bcm})$ & 2020 & 2025 & 2030 \\
\hline IEA NPS & & & $225(2035)$ \\
\hline IGU & & & $40-45$ \\
\hline Shell & $9-12$ & $18-25$ & \\
\hline BP $^{*}$ & 82 & 117 & 162 \\
\hline Citi $^{*}$ & $89-123$ & & $175-316$ \\
\hline
\end{tabular}

Source: See text

* Includes marine

In global terms the main forecasts for marine transport are:

- IEA - The World Energy Outlook for $2013^{214}$ has taken in its words "a cautious approach" in projecting global gas usage of $5 \mathrm{bcm}$ in 2035 .

- Lloyds Register (2012) commissioned a range of forecasts from MSI of the demand for new LNG-fuelled ships and LNG as a fuel for deep sea shipping up to 2025. Their base case forecast puts global LNG demand at $3.2 \%$ of HFO bunker demand in 2025.

- DNV (2012) - has developed a set of forecasts as part of a study of the impact on trends in transport demand, marine regulations and technology. It forecasts that LNG will fuel globally around 1,000 ships by 2020 consuming between 4 and $7 \mathrm{mtpa}$ and accounting for around $14 \%$ of all ship new-builds ${ }^{215}$.

- Shell -has presented some projections ${ }^{216}$ for LNG use in marine indicating a $10 \%$ to $20 \%$ share for natural gas.

- Total SA $\mathrm{SA}^{217}$ - estimates that LNG demand for marine transport could reach 11-mtpa in 2020 and 33-mtpa in 2030 accounting for $5 \%$ and $10 \%$ of the overall marine fuel market respectively.

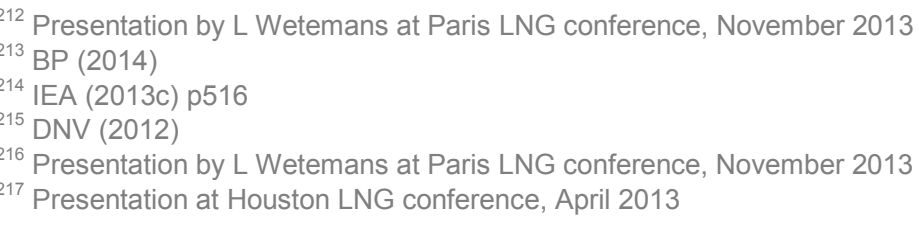



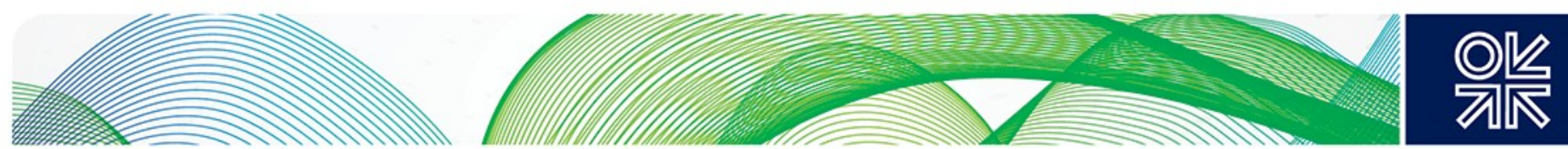

- $U C L^{218}$ - modelled market shares for alternative fuels on the marine sector to 2050 for three scenarios (status quo, global commons and competing nations). The status quo case shows strong growth in LNG demand post 2020 to account for over half the modelled fuel demand by 2035 . Other scenarios suggest either LSFO or hydrogen will become the dominant fuel.

Whilst all of the above expect some degree of switch to gas both DNV and UKPIA expect that more shipping will switch to gasoil as shown in Figure 30. This is based on DNV's scenario D which assumes low OECD growth of $2 \%$ pa, no carbon pricing, a postponement of the global sulphur limit to 2020 , a MGO/HFO premium of $150 \%$ and a LNG/HFO discount of $70 \%$. UKPIA expects gasoil demand in Europe in 2015 to increase by around $15 \mathrm{mtoe}$ to $^{219}$.

\section{Figure 30: Global fleet fuel mix (DNV Scenario D)}

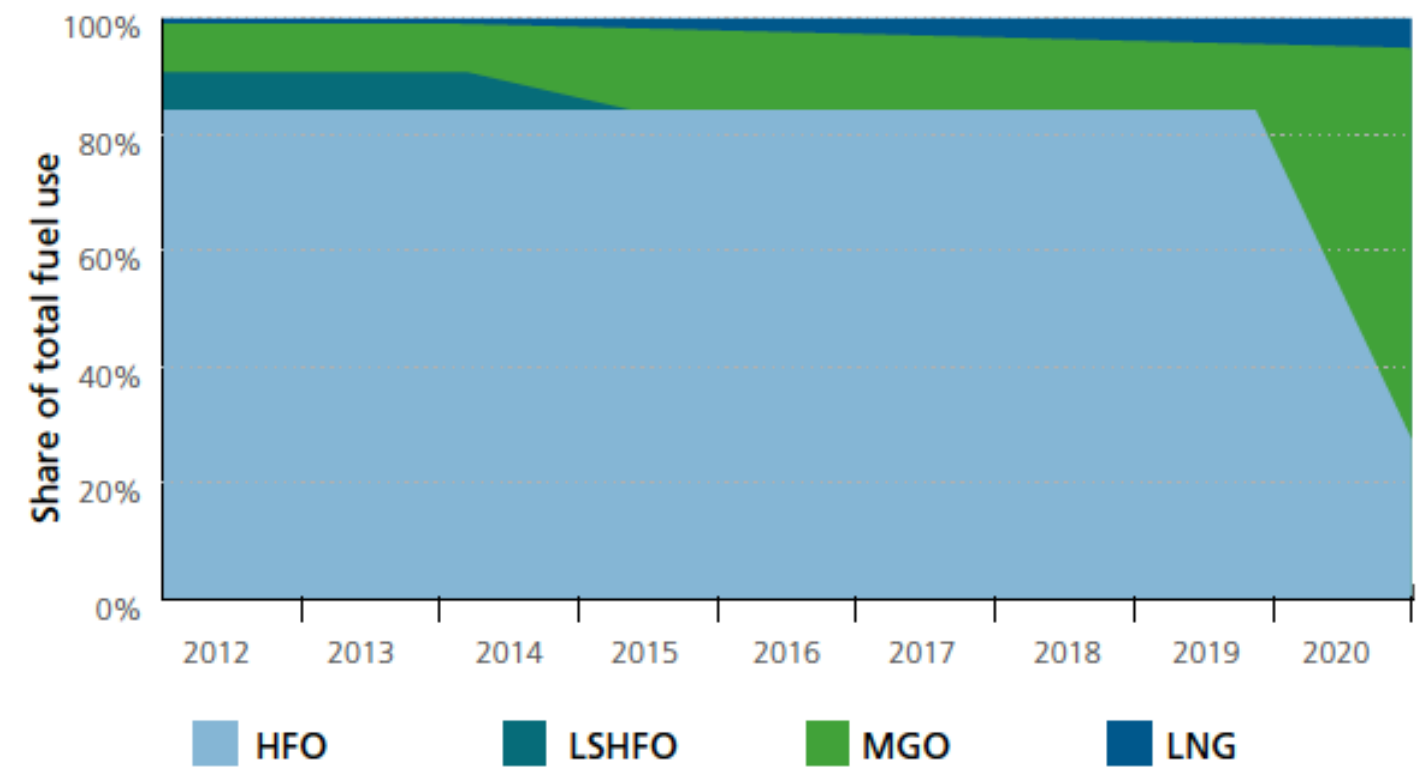

Source: DNV (2012)

These forecasts are summarised in Table 41 converted to bcm of natural gas where appropriate.

Table 41: International marine gas demand external forecasts (bcm)

\begin{tabular}{|l|c|c|c|c|}
\hline Forecast & 2015 & 2020 & 2025 & 2030 \\
\hline IEA NPS & & & & $5(2035)$ \\
\hline Lloyds & $0-1$ & $0-3$ & & $6-52$ \\
\hline Shell & & $7-18$ & $22-90$ & \\
\hline DNV & & $11-45$ & & \\
\hline Total SA & 0 & 15 & & 45 \\
\hline
\end{tabular}

Source: See text

\footnotetext{
${ }^{218}$ Raucci et al (2013), the forecast numbers appear to be on a different basis from the other studies so have not been tabulated

${ }^{219} \mathrm{http} / / /$ www.ukpia.com/industry_issues/fuels/marine-fuel.aspx
} 

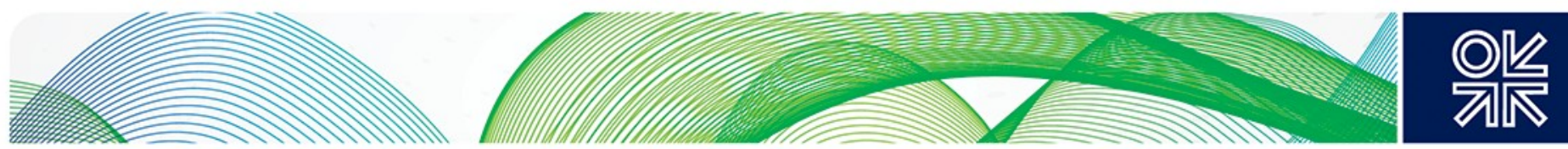

Most of the above forecasts do not provide separate numbers for Europe though there are some separate studies that have focussed just on Europe. The main forecasts identified for gas usage in transportation in Europe are as follows:

- Eurogas (2013a) which predicts a seven fold increase in demand subject to the right political environment and coordinated support from all stakeholders.

- The IEA (2013c) is more cautious on the prospects for NGVs in Europe than elsewhere and projects the gas share of total road-fuel energy demand for the EU to rise from $0.4 \%$ to $1.3 \%$ by 2035 .

- Citi (2013) has published some global projections on gas demand for transportation broken down by regions including Europe

- The European Gas Forum (2012) produced long-range forecasts of natural gas usage in road and marine transport in the EU consistent with meeting the EC Transport White Paper ${ }^{220}$ targets set out in 4.2.1 in a cost effective manner. The baseline scenario focuses primarily on technological solutions and pricing signals to meet the target and an alternative scenario that places significant emphasis on an increasing role for natural gas - particularly in the HGV sector.

- The European Expert Group on Future Transport Fuels have drawn their view from the NGVA Europe. This states that assuming refuelling infrastructure increased from 2,300 CNG filling stations in the EU to 4,000; and from 23 LNG stations to 200; Biogas upgrading plants and injection points increased to 400 ; coupled with extensive expansion of port/harbour LNG fuelling across Europe, the expectation is that the NGV population could grow significantly to reach a total market share of $5 \%$ by $2020,9 \%$ by 2030 and $16 \%$ by 2050 for both passenger and freight transport. This is broadly similar to the European Gas Forum Alternative Scenario though the latter assumes a slower build-up with a market share of only $3.3 \%$ for natural gas in 2030 .

The Danish Maritime Authority (DMA) which has undertaken extensive modelling of expected switching to LNG has developed a separate marine only forecast. The DMA analysis has included both new build and retro fit of existing vessels for a range of scenarios portraying price differentials between LNG and MGO and HFO. Scenario 2 which is the central case of MGO at $€ 885 /$ tonne and LNG at $€ 610 /$ tonne suggests that LNG demand will be 2 mtpa in 2015 , exceed $4.2 \mathrm{mtpa}$ in 2020 growing to around $7 \mathrm{mtpa}$ by 2030 . In the early years much of the gas demand comes from ships that have been retrofitted to burn LNG, but by 2030 half the demand comes from new build shipping ${ }^{221}$.

These forecasts are summarised in Table 42 converted to bcm of natural gas where appropriate.

Table 42: European demand for gas in transportation - external forecasts

\begin{tabular}{|l|c|c|c|}
\hline Forecast $(\mathrm{bcm})$ & 2015 & 2020 & 2030 \\
\hline IEA - Road only & & & $3.8(2035)$ \\
\hline Citi - Base EU & 3 & 5 & 8 \\
\hline Eurogas & 3 & $7(2025)$ & $16(2035)$ \\
\hline EGF EU Baseline & 1.2 & 1.5 & 2.9 \\
\hline EGF EU Alternative & 1.3 & 2.6 & 14 \\
\hline EEGFTF/NGVA & & 24 & 43 \\
\hline DMA Marine only & 3 & 6 & 10 \\
\hline
\end{tabular}

Source: See text

\footnotetext{
European Commission (2011a )

${ }^{21}$ DMA (2013)
} 

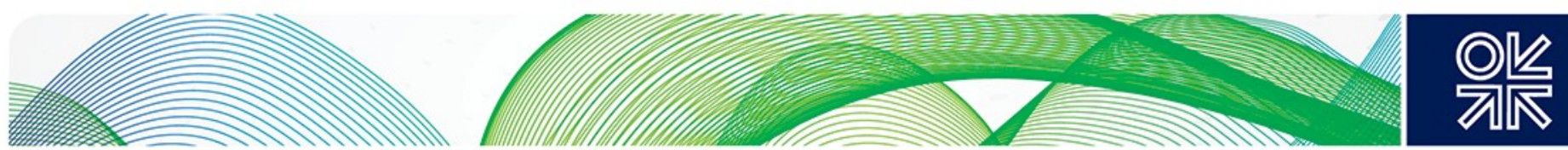

Even if the introduction of a global $0.5 \%$ sulphur limit is postponed to or beyond 2020 this is unlikely to have a major impact on European demand for LNG for ships.

Table 43 presents the combined projections for gas demand in transport for Europe developed by this study.

Table 43: European Demand for gas in transportation - summary of study projections (bcm)

\begin{tabular}{|c|c|c|c|c|c|c|c|c|}
\hline \multirow{2}{*}{$\begin{array}{c}\text { Ultimate } \\
\text { Market } \\
\text { share } \\
\text { case }\end{array}$} & \multicolumn{2}{|c|}{$\begin{array}{c}\text { Projected } \\
\text { Consumption } \\
\text { Road }\end{array}$} & \multicolumn{2}{|c|}{$\begin{array}{c}\text { Projected } \\
\text { Consumption } \\
\text { Marine }\end{array}$} & \multicolumn{2}{|c|}{$\begin{array}{c}\text { Projected } \\
\text { Consumption } \\
\text { Total }\end{array}$} & \multicolumn{2}{|c|}{ Of which LNG } \\
\hline & 2020 & 2025 & 2020 & 2025 & 2020 & 2025 & 2020 & 2025 \\
\hline Low & 11.8 & 16.6 & 1.5 & 3.1 & 13.3 & 19.7 & 2.9 & 5.4 \\
\hline Medium & 21.6 & 34.5 & 3.1 & 6.2 & 24.7 & 40.7 & 9.6 & 17.8 \\
\hline High & 44.3 & 76 & 6.2 & 12.3 & 50.5 & 88.3 & 20.0 & 37.2 \\
\hline
\end{tabular}

Source: Author's analysis

The projections in Table 43 exclude Russia and Ukraine, which could account for up to 60 $\mathrm{bcm}$ additional demand if the Russian Government targets are met and reduced gas prices in Ukraine persist. It would appear that this study's mid case projection is at the upper end of most external forecasts with these clustering around or below the study's low case.

\subsection{Summary of the outlook for future usage of natural gas in transport}

The next stage of development of the NGV market in Europe is open to a wide range of possibilities and this is reflected in the forecasts. Perhaps not surprisingly the most optimistic forecasts come from the NGVA trade association with Eurogas and the European Gas forum presenting relatively optimistic forecasts that still suggest relatively low market shares for natural gas in transportation.

If these lower forecasts turn out to be correct it suggests either that the pace of NGV development is possibly too slow to encourage major investments from OEMs and infrastructure providers or that the rate of growth will vary significantly across Europe with most activity occurring around an emerging LNG supply chain in North and West Europe. The variation in developments across Europe suggests that the latter outcome is more likely at this stage though it is important to bear in mind that given the still early stage of many initiatives the picture could change radically in a relatively small period. 


\section{Conclusions}

\subsection{The overall prospects for natural gas usage in transport in Europe}

In summarising the outlook for natural gas in transport it is possible to categorise the myriad issues facing the various stakeholders as first and second order issues.

The first order issues relate to basic questions as to whether natural gas is a realistic fuelling alternative such as:

- Is there a financial case for natural gas?

- Are there strong environmental benefits?

- Is it practical and in particular are there appropriate vehicles and refuelling facilities to meet the needs of users?

- Is the case stronger than, and the best alternative to, the status quo?

As we have seen the financial case primarily hinges on the extent to which the price discount of natural gas to gasoil or diesel outweighs the costs of a natural gas-powered vehicle or vessel. For marine applications this is a simple matter of commodity prices and the present relativities suggest a positive case for natural gas. However, for road transport the differential taxation levels (which typically account for two thirds of the difference) play a crucial role. Whilst the payback time on NGV investments is in general such that for most truck applications there is a positive incentive to switch, the reliance on fiscal terms to make the business case is a real concern amongst operators. The main worry is that given the importance that fuel taxes play in raising revenue it is unrealistic to expect the present favourable discount to be maintained if there is large scale switching. This is clearly less of an issue in marine as fuel prices are generally not subject to tax.

There are clear environmental benefits from adopting natural gas in terms of reduced GHGs and zero particulate emissions - this latter point is particularly important in urban areas for large trucks and buses. The lack of sulphur emissions is an additional strong benefit in the marine and IWT sector. The benefits in the car sector are less marked in part due to the rapidly improving performance of conventional and hybrid vehicles and the commitment of some governments to electric cars - which are seen as ultimately providing a route for decarbonising this sector of transportation. Biomethane further improves the environmental case though as we have see there are issues over the extent to which this might be a scalable option for the transport sector. Overall the environmental dilemma facing natural gas in the transport sector is not dissimilar to the one it faces in power generation. It is a lower carbon alternative to other fossil fuels but not completely carbon free - this means policy makers seem unwilling to commit to a natural gas route in the expectation (hope?) that zero carbon renewables will eventually become economic. However this creates an inertia that results in options such as coal-fired generation remaining in play and so emissions are higher than they could otherwise be.

In terms of practicality the key issue is one often referred to as the chicken and egg problem. Insufficient refuelling infrastructure inhibits growth in new vehicle purchase, which in turn inhibits investment in infrastructure. This circularity applies equally to new vehicles, with manufacturers showing reluctance to develop a comprehensive range of offerings in the absence of clear interest from the market. A combination of economic, reputational and 

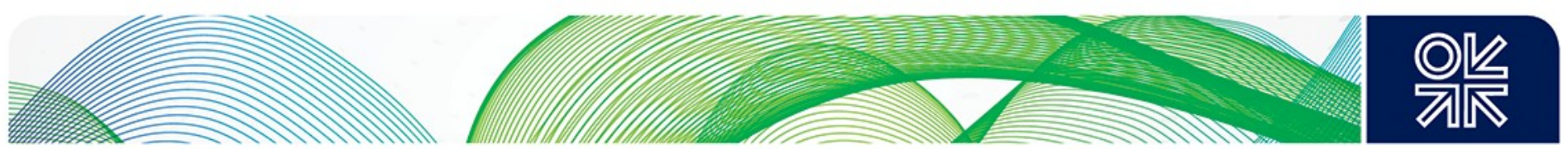

regulatory signals is pushing natural gas (and LNG in particular) as a promising option for larger trucks and marine vessels and this is stimulating some risk based investment in infrastructure and greater interest from manufacturers. This impetus is less obvious in the car sector - particularly in those countries such as the UK that have expressed a preference for electric vehicles as a way of "greening" personal transport - though as we have seen this objective may take many years to achieve. The inherent flexibility of the existing fuel supply and vehicle network can act as a strong disincentive to switch to new, largely untried, alternatives

The final first order issue is the question of how natural gas stands vis a vis the status quo and other alternatives. The status quo liquid fuels deliver a high energy content in a small volume. They are also easy to store and to handle, global standards and regulations are well developed, the cost of existing fuelling infrastructure is fully amortised and the vehicle production supply chain is optimised. Furthermore conventional fuel efficiency continues to improve. The IEA estimates that globally fuel consumption for heavy ( $>16$ tonnes) trucks will move from 35 litres $/ 100 \mathrm{~km}$ in 2011 to 28 litres $/ 100 \mathrm{~km}$ by 2035 . Comparable numbers for Europe are 31 litres $/ 100 \mathrm{~km}$ and 26 litres $/ 100 \mathrm{~km}^{222}$. Furthermore relatively minor investments in vehicle efficiency can generate significant benefits. For example a study by Ricardo-AEA (2012) suggests that improving aerodynamic efficiency and reducing rolling resistance in HDV can generate up to $10 \%$ WTW savings in emissions - this is clearly less than the $65 \%$ (biomethane) or $16 \%$ (methane) WTW savings from switching to gas but arguably quicker and less risky to achieve.

Natural gas has to demonstrate it can match all of these attributes and deliver significant benefits. The challenge can be summarised as 'nobody got fired for buying IBM' - in other words moving to natural gas may present a significant risk to vital operations that outweigh the advantages. Even if a move away from the status quo fuels is seen as desirable is natural gas the best option? Again the picture is mixed across the sectors, with the heavy truck and marine modes presenting the best opportunity at present. In passenger cars and (to a lesser extent) buses, electricity, or even hydrogen, are also being promoted as the best option though the evidence on WTW emissions suggests that at present electricity is only marginally preferable - particularly when compared to a biomethane/natural gas mix. In these sectors NGVs may be an answer but not necessarily the answer.

These first order questions are summarised by mode in table 44 which, in broad terms, suggests that the answer to the question of whether natural gas is a realistic fuelling alternative is yes for heavy trucks and marine, possibly for buses with the case for passenger cars being hardest to make. 

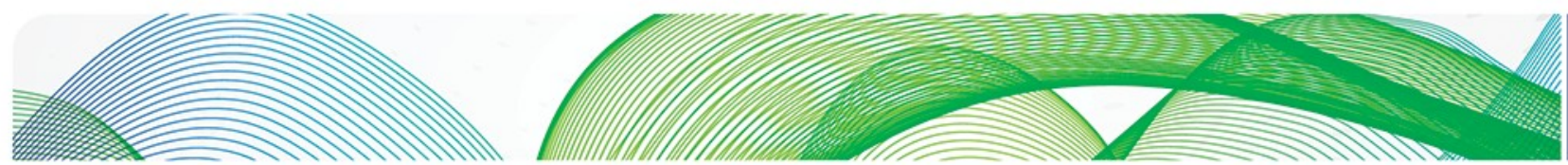

Table 44: Summary of "first order" issues for natural gas in transportation

\begin{tabular}{|c|c|c|c|c|}
\hline \multirow{2}{*}{$\begin{array}{l}\text { First order } \\
\text { question }\end{array}$} & \multicolumn{3}{|c|}{ Road } & \multirow[t]{2}{*}{ Marine/IWT } \\
\hline & Car & Bus & $\mathrm{M} / \mathrm{HDV}$ & \\
\hline Financial case? & $\begin{array}{l}\text { Yes but fiscal } \\
\text { position is } \\
\text { important }\end{array}$ & $\begin{array}{l}\text { Yes but } \\
\text { depends on } \\
\text { subsidy/fiscal } \\
\text { environment }\end{array}$ & $\begin{array}{l}\text { Yes - } \\
\text { particularly for } \\
\text { high usage but } \\
\text { fiscal position is } \\
\text { important }\end{array}$ & Yes \\
\hline $\begin{array}{l}\text { Environmental } \\
\text { benefits? }\end{array}$ & $\begin{array}{l}\text { Marginal unless } \\
\text { biogas used }\end{array}$ & Yes & Yes & Yes \\
\hline $\begin{array}{l}\text { Practicability in } \\
\text { terms of } \\
\text { vehicles and } \\
\text { refuelling } \\
\text { facilities }\end{array}$ & $\begin{array}{l}\text { Limited vehicles, } \\
\text { patchy network }\end{array}$ & $\begin{array}{l}\text { Vehicles and } \\
\text { refuelling } \\
\text { available for } \\
\text { most } \\
\text { applications }\end{array}$ & $\begin{array}{l}\text { Limited vehicles } \\
\text { but improving. } \\
\text { LNG network } \\
\text { needs } \\
\text { expanding }\end{array}$ & $\begin{array}{l}\text { Vessels can be } \\
\text { built/retro-fitted } \\
\text { as required. } \\
\text { Very limited } \\
\text { LNG network at } \\
\text { present }\end{array}$ \\
\hline $\begin{array}{l}\text { The best } \\
\text { alternative to } \\
\text { the status quo } \\
\text { and } \\
\text { alternatives? }\end{array}$ & $\begin{array}{l}\text { Status quo is } \\
\text { improving and } \\
\text { hybrid-electric } \\
\text { vehicles also } \\
\text { present a viable } \\
\text { alternative }\end{array}$ & $\begin{array}{l}\text { Possibly due to } \\
\text { zero particulate } \\
\text { emissions } \\
\text { though electric } \\
\text { vehicles may } \\
\text { present a viable } \\
\text { alternative }\end{array}$ & $\begin{array}{l}\text { Possibly due to } \\
\text { zero particulate } \\
\text { emissions, price } \\
\text { advantage and } \\
\text { improvements in } \\
\text { LNG engine } \\
\text { technology }\end{array}$ & $\begin{array}{l}\text { Possibly due to } \\
\text { zero particulate } \\
\text { emissions and } \\
\text { price advantage }\end{array}$ \\
\hline
\end{tabular}

The second order issues revolve around questions of by how much and when natural gas might be adopted. This study has presented some projections that are aimed to give a sense of the possible orders of magnitude involved - it is not the intention to provide forecasts. Nevertheless there are a number of factors that must be resolved before consistent growth is likely to be achieved. The most important of these are:

- The pace of roll-out of new infrastructure and vehicles;

- The availability or otherwise of funding for infrastructure and vehicles (including funding for alternatives);

- The extent to which operating and other standards are harmonised;

- The extent of any planning restrictions on refuelling and using natural gas (particularly LNG) in transportation;

- The reliability of the gas supply chain and the vehicles using it as a fuel;

- The ability of the regional dealership network to supply and service gas vehicles to a required standard.

Many of these second order issues have still to be resolved, though there is the sense that some progress is being made on a number of fronts and a clearer picture should be apparent by the end of 2014. It is likely that the rate of growth will continue to vary significantly across Europe with most activity occurring around an emerging LNG supply chain in North and West Europe. 

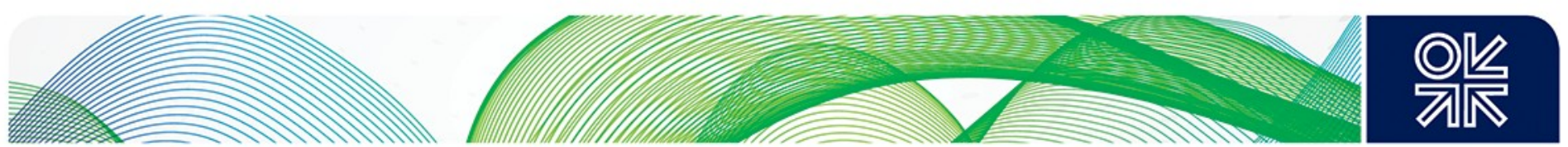

If delivery on issues such as standards and construction of planned refuelling stations has not been achieved then many of the more optimistic forecasts must be questioned, as it is unlikely that sufficient momentum amongst key consumer groups will emerge. Whilst OEMs and energy supply and infrastructure companies will always express a willingness to be active in this market they are unlikely to make any significant commitments in the absence of such momentum.

\subsection{Other issues and considerations}

\subsubsection{Pricing}

It is still far from clear how gas in transportation might ultimately be priced. Some retailers have suggested it will be at a fixed discount to diesel/MGO in the road and marine sectors. Others have argued that hub-based prices will be more appropriate (and necessary) to build the market whilst grid-based supplies will need to take account of the charges made to other users.

One interesting dimension is that if natural gas does become a significant fuel in the transport sector it will again be competing with oil products in the European market. This could have implications for both spot and contract pricing as well as the development of derivatives.

\subsubsection{Biogas}

This study has noted the clear and substantial additional environmental benefits from basing the NGV offering on biogas. It has also been emphasised though that in many countries supplies could be severely restricted. It is also not clear that using biomethane in transportation necessarily represents the most efficient way of utilising this particular resource. The industry should be mindful of the potential risks of placing too high a dependence on biomethane as the key factor in encouraging a broader development of NGVs.

\subsubsection{An alternative gas supply chain?}

The use of LNG to supply remote networks is well established in some countries such as Spain. The development of a broader cryogenic network throughout W Europe could open further opportunities for supplying new users. National Grid (NG) sees a potential in the UK for supplies of $0.6 \mathrm{mtpa}$ to off-grid I\&C consumers who presently buy much more expensive LPG.

Furthermore the ability to procure gas from LNG suppliers direct may bring a number of new retail players into the gas sector operating in similar ways to the heating oil sector. This could in time result in genuine supply competition for large and medium size gas users.

\subsection{Policy prescriptions and likely outcomes}

Some of the obstacles identified by this research are not particularly amenable to policy interventions or could bring some unwelcome unintended consequences. However there are 

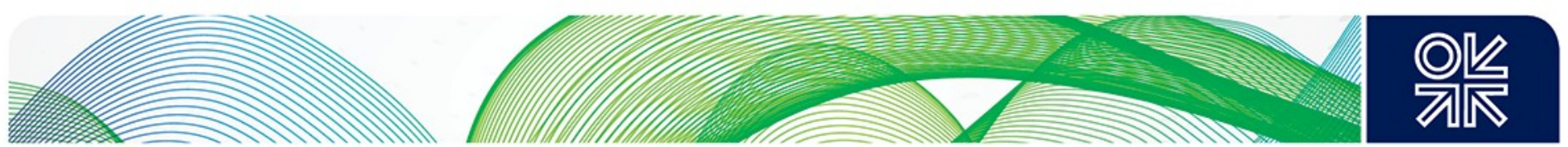

some areas where either government or concerted industry action could potentially generate some benefits. These are described in this section.

\subsubsection{Pricing}

Governments that want to encourage NG usage should make clear long-term commitments (for 5 years at least) that the differential between excise duties will be maintained. The industry should also seek to provide some clear signals on how refuelling and other infrastructure costs are likely to be charged.

\subsubsection{Infrastructure}

Total spend on new infrastructure has been estimated by the EC to amount to $€ 322$ million for road transport and over $€ 2$ billion for marine and inland waterways. The EC notes that Member States will be able to implement these investments without necessarily involving public spending by changing local regulations to encourage private sector investment and behaviour. In addition EU support is already available from TEN-T, cohesion and structural funds.

Given the risk of asset stranding, incentives/assistance for infrastructure should be carefully considered. Attempts by the EU to crack the "chicken and egg" problem may hatch a white elephant - particularly as the strategy also encompasses electricity and hydrogen infrastructure. For this reason, and given that a number of national initiatives are already underway, the involvement of private investment as part of an industry led approach may be most appropriate albeit developed within a supportive European framework that aims to develop a network of appropriately sized refuelling stations with guaranteed access for third parties.

A further consideration is that LNG has the advantage of offering a route to developing a more flexible, lower cost infrastructure than grid-based CNG. LNG refuelling sites can be quickly scaled up or down, or even relocated, to reflect emerging demand levels and can be used to incorporate CNG refuelling where necessary.

\subsubsection{Standards and procedures}

Progress is being made in this area though it may tend to lag developments on the ground. All stakeholders will have to balance the urge to make progress against the risk of running into technical blind alleys. Companies with a global presence in LNG supply and logistics can play a particular role in this regard.

\subsubsection{Promotion}

There are a huge number of initiatives and pilot projects in the NGV space in Europe and many are promoting different approaches. Examples include CNG versus LNG and biomethane versus natural gas. Whilst there may be a case for developing a range of options the industry should guard against trying to cover too many bases, thereby diluting its effort and confusing the market. Where possible players should aim to be more focussed on delivering specific, scalable projects - Blue corridors is a good example. 


\section{Appendix A}

\section{Modelling methodology}

This appendix summarises the approach and assumptions used in modelling the financial break-even calculations and growth projections.

\section{Financial break-even calculations}

The break-even calculations are based on the undiscounted payback for the additional cost of a natural gas vehicle set against the savings made in fuel costs per kilometre.

For HGVs the capital cost premium was assumed to be $€ 50,000$ with additional running costs of $€ 5,000$ pa.

Fuel costs were based on following consumption rates from vehicle trials:

LNG vehicles consumed $27 \mathrm{~kg}$ of LNG $/ 100 \mathrm{~km}$

Diesel vehicles consumed 32 litres/100km

And average diesel and LNG costs of $€ 1.30 /$ litre and $€ 1.05 / \mathrm{kg}$ respectively. This generated the following distance related costs.
Cost per kilometre for Diesel truck
$0.5632 € / \mathrm{km}$
Cost per kilometre for LNG truck
$0.2835 € / \mathrm{km}$

Tax information is based on data in http://ec.europa.eu/taxation customs/resources/documents/taxation/excise duties/energy pr oducts/rates/excise duties-part ii energy products en.pdf

Diesel tax rates are levied per litre and natural gas taxes are levied per Gigajoule. VAT was ignored as it is the same for both fuels. Equivalent tax rates per unit if energy consumed were calculated and these were then used to determine the tax cost per kilometre

\begin{tabular}{|l|r|r|r|r|}
\hline Tax charges & \multicolumn{1}{|l|}{$€$ /litre } & \multicolumn{1}{l|}{$€ /$ GigaJ } & \multicolumn{2}{l|}{ Cost in $€$ per kilometre } \\
\hline & \multicolumn{1}{|l|l|l|}{ Diesel } & NG & \multicolumn{1}{l|}{ Diesel } & NG \\
\hline France & 0.428 & 0 & 0.14 & 0.00 \\
\hline Germany & 0.46 & 3.86 & 0.15 & 0.05 \\
\hline Netherlands & 0.44 & 5.29 & 0.14 & 0.08 \\
\hline UK $€$ & 0.67 & 6.59 & 0.21 & 0.09 \\
\hline
\end{tabular}

For cars the capital cost premium was as stated in the text with additional running costs assumed to be zero. 

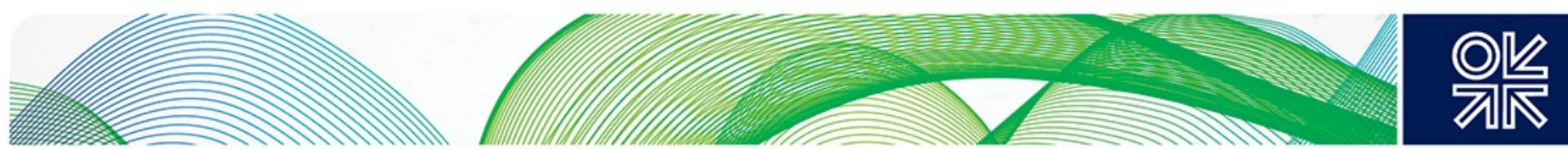

Fuel costs were based on EU average prices from NGVA. Using reported average consumption rates from users in Germany as shown on the http://www.spritmonitor.de/ website. This gives the following costs for the Mercedes B200 and for the VW Golf which includes a petrol option.

\begin{tabular}{|l|r|l|}
\hline Mercedes B200 & & \\
\hline Cost per kilometre for NGV car & 0.063 & $€ / \mathrm{km}$ \\
\hline Cost per kilometre for Diesel car & 0.094 & $€ / \mathrm{km}$ \\
\hline VW Golf & & \\
\hline Cost per kilometre for NGV car & 0.057 & $€ / \mathrm{km}$ \\
\hline Cost per kilometre for Diesel car & 0.075 & $€ / \mathrm{km}$ \\
\hline Cost per kilometre for petrol car & 0.123 & $€ / \mathrm{km}$ \\
\hline
\end{tabular}

\section{Growth projections}

The growth projections are based on the following assumptions.

\begin{tabular}{|l|r|r|}
\hline Vehicle type & $\begin{array}{l}\text { Average } \\
\text { consumption } \\
\text { in M3/year }\end{array}$ & Total Vehicles \\
\hline Car/LCV & 2160 & $343,200,000$ \\
\hline Bus & 36000 & 780,000 \\
\hline MCV & 24000 & $12,000,000$ \\
\hline HGV & 60000 & $2,000,000$ \\
\hline
\end{tabular}

The final market penetration after 10 years is set as an external assumption and it is assumed that there is a linear build-up over 10 years to reach this level. So if the market share for buses after 10 years is $10 \% 7,800$ new NGV buses will be built per annum. These numbers are then used to calculate the total NGV bus population in 2020 and 2025 assuming the new build rate continues after 10 years.

Gas consumption is then calculated by multiplying the number of vehicles in the particular year by the average fuel consumption figures (provided by NGVA) adjusted to take account of annual improvements in fuel efficiency which are assumed to be $2 \%$ pa. 

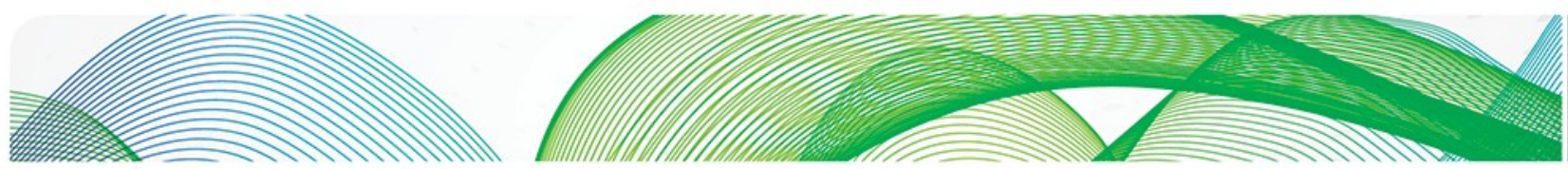

\section{Bibliography}

ACEA (2013), Automobile Industry Pocket Guide, 2013, European Automobile Manufacturers Association, 2013, http://www.acea.be/publications/archives/category/acea-pocket-guide

ANFAC (2012) European Motor Vehicle Parc, 2010, http://www.acea.be/collection/statistics

Atkins et al (2013) Atkins P., Cornwell R, Tebbutt N \& Schonau N, Preparing a low CO2 technology roadmap for buses, Final Report - updated 3 July 2013 Ricardo, www.ricardo.com

AVERE (2012); Data Collection, 2012, The European Association for Battery, Hybrid \& Fuel Cell Electric Vehicles.

http://www.avere.org/www/Images/files/EV\%20Data\%20Collection\%20AVERE(1).pdf Baldwin J and McKeon R (2012), High Pressure Grid CNG: The low $\mathrm{CO}_{2}$ option for HGVs, CNG Services Ltd, presentation to I Mech E Sustainable Vehicle Technologies (SVT) conference 14 November 2012.

http://events.imeche.org/DocumentDownload.aspx?EventID=970

Batterbee $J$ \& Lidstone $L$ (2013), An affordable transmission to sustainable and secure energy for light vehicles in the UK, Presentation to the Energy Institute, 6 June 2013;

BP (2013), Statistical Review of World Energy, June 2013

http://www.bp.com/content/dam/bp/excel/Statistical-

Review/statistical_review_of_world_energy_2013_workbook.xlsx

BP (2014), BP Energy Outlook 2035, January 2014, http://www.bp.com/energyoutlook

Brightman et al (2011): Brightman T, Parker T \& Matthews C, Biomethane for TransportHGV cost modeling, Report Prepared for Low Carbon Vehicle Partnership, Transport \& Travel Research Ltd, October 2011 http://www.lowcvp.org.uk/resource-library/reportsand-studies.htm

Carrol S., see Cenex (2012)

Cenex (2012), The Coca-Cola Enterprises Biomethane Trial Report, March 2012, http://www.cenex.co.uk/consultancy/vehicle-deployment-trials/coca-cola-hgv-trial

Chua et al (2010) ; Chua, W. Y., Lee A, Sadeque s., Who do people buy hybrid cars?, in Proceedings of Social Marketing Forum, 2010 University of Western Australia, Perth, Western Australia, Edith Cowan University, Churchlands, W.A., pp. 1-13. http://www.jrconsumers.com/documents/social marketing forum proceedings/Chua Lee Sedeque.doc

Citi (2013): Start your natural gas engines, Citi Global Perspectives \& Solutions, June 2013, https://www.citivelocity.com/citigps/ReportSeries.action?recordld=19

CNG Services (2012); Use of Natural gas as a Vehicle Fuel, Unpublished study, 2012

Danish Maritime Authority, 2011, North European LNG Infrastructure Project, May 2012 http://www.dma.dk/themes/LNGinfrastructureproject/Sider/ReferenceDocuments.aspx 

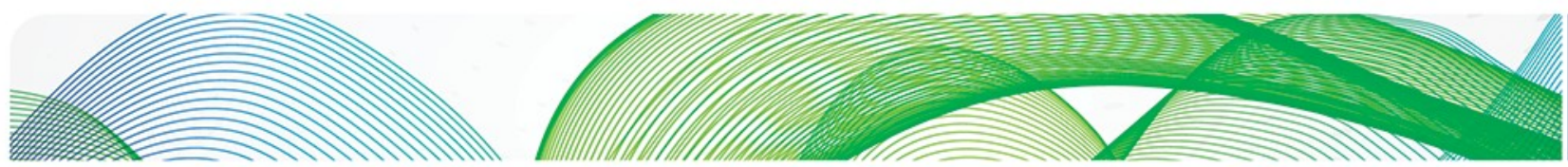

Davis et al (2013): Davis S, Diegel S and Boundy, Transportation Energy Data book, Edition 32, Oakridge National Laboratory, July 2013, http://cta.ornl.gov/data/tedb32/Edition32_Full_Doc.pdf

DECC (2012b); Annual Energy Statement 2012, Cm 8456, November 2012 http://www.decc.gov.uk/en/content/cms/meeting_energy/aes/aes.aspx

Demin, D, 2013, Compressed Natural gas in Russia, Research note by Denis Demin, August 2013 Available from d.n.demin@gmail.com

DNV (2012); Shipping 2020, 2012, http://www.dnv.nl/binaries/shipping\%202020\%20\%20final\%20report_tcm141-530559.pdf

Edwards et al (2011): Edwards R, Larive J-F, Beziat J-C, 2011, Well-to-wheels Analysis of Future Automotive Fuels and Powertrains in the European Context, Version 3c, JEC Joint Research Centre-EUCAR-CONCAWE collaboration, EUR 24952 EN-

$2011 \mathrm{http}$ ://iet.jrc.ec.europa.eu/about-jec/sites/iet.jrc.ec.europa.eu.aboutjec/files/documents/wtw3_wtw_appendix2_eurformat.pdf

Edwards et al (2013): Edwards R, Larive J-F, Rickeard D, Weindorf W, Well to tank report Version 4.0, JEC Joint Research Centre-EUCAR-CONCAWE collaboration, EUR 26028 EN-2013

EEGFTF (2011a), Future Transport Fuels, European Expert Group on Fuels for the Future, January 2011

EEGFTF (2011b) Infrastructure for Alternative Fuels, European Expert Group on Fuels for the Future, December 2011

EMSA (2013) European Maritime Safety Agency- Study on Standards and

Eurogas (2013a), Long Term Outlook for gas to 2035, Eurogas, Brussels, October 2013 http://www.eurogas.org/uploads/media/Eurogas_Brochure_Long-

Term_Outlook_for_gas_to_2035.pdf

Eurogas (2013b), Statistical Report,2013, Eurogas, Brussels, December 2013, http://www.eurogas.org/uploads/media/Eurogas_Statistical_Report_2013.pdf

European Commission (2007), Well to Wheels Report, Version 2c, March 2007 http://ies.jrc.ec.europa.eu/uploads/media/WTT_Report_010307.pdf

European Commission (2009a), Fuel Quality Directive, DIRECTIVE 2009/30/EC, 23 April 2009

http://eurlex.europa.eu/LexUriServ/LexUriServ.do?uri=OJ:L:2009:140:0088:0113:EN:PDF

European Commission (2009b), Renewable Energy Directive, DIRECTIVE 2009/28/EC, 23 April 2009,

http://eurlex.europa.eu/LexUriServ/LexUriServ.do?uri=OJ:L:2009:140:0016:0062:EN:PDF

European Commission (2009c), Directive on the promotion of clean and energy-efficient road transport vehicles, DIRECTIVE 2009/33/EC, 23 April 2009 http://eur-

lex.europa.eu/LexUriServ/LexUriServ.do?uri=OJ:L:2009:120:0005:0012:en:pdf

European Commission (2009d); Regulations setting emission performance standards for new passenger cars as part of the community's integrated approach to reduce $\mathrm{CO} 2$ emissions from light-duty vehicles, 23 April 2009, Brussels http://ec.europa.eu/enterprise/sectors/automotive/environment/co2emissions/index_en.htm 

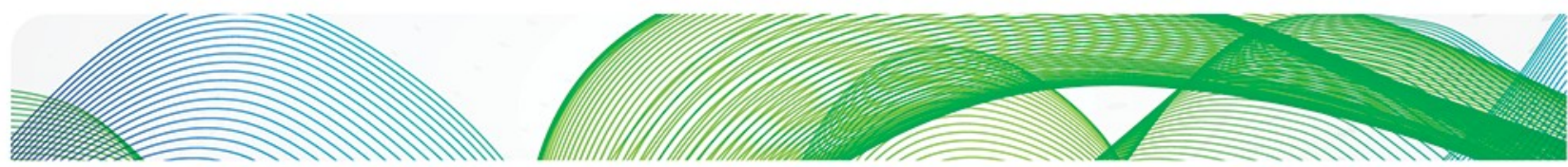

European Commission (2011a); Roadmap to a Single European Transport Area Towards a competitive and resource efficient transport system", White paper, 28th March 2011, Brussels http://ec.europa.eu/transport/themes/strategies/2011_white_paper_en.htm

European Commission (2011b); Regulations setting emission performance standards for new light commercial vehicles as part of the Union's integrated approach to reduce CO 2 emissions from light-duty vehicles 11 May 2011, Brussels http://ec.europa.eu/enterprise/sectors/automotive/environment/co2emissions/index_en.htm

European Commission (2013a); European alternative fuels strategy, Brussels, 24.1.2013 $\operatorname{COM}(2013) 17$ final

http://eurlex.europa.eu/LexUriServ/LexUriServ.do?uri=COM:2013:0017:FIN:EN:PDF

European Commission, 2013b; Directive on the deployment of alternative fuels infrastructure, Brussels, 24.1.2013 COM(2013) 18 final http://eurlex.europa.eu/LexUriServ/LexUriServ.do?uri=COM:2013:0018:FIN:EN:PDF

European Commission, 2013c; Actions towards a comprehensive EU framework on LNG for shipping, Brussels, 24.1.2013 SWD(2013) 4 final http://eurlex.europa.eu/LexUriServ/LexUriServ.do?uri=SWD:2013:0004:FIN:EN:PDF

European Commission, 2013d; Excise Duty Tables, Part II - Energy Products and Electricity, Ref 1038 Rev 1, July 2013

http://ec.europa.eu/taxation_customs/resources/documents/taxation/excise_duties/energy _products/rates/excise_duties-part_ii_energy_products_en.pdf

European Commission,2013e; EU Energy in figures, Pocket Book 2013 ec.europa.eu/energy/publications/doc/2013_pocketbook.pdf

European Gas Forum, 2012, Reducing CO2 emissions in the EU Transportation Sector to 2050, September 2012, http://europeangasforum.eu/2012/09/26/reducing-co2-emissionsin-the-eu-an-alternative-pathway-to-reach-2050/

Europia, 2011, Annual Report 2011, European Petroleum Industry Association, Brussels https://www.europia.eu/DocShareNoFrame/Common/GetFile.asp?PortalSource=1361\&D oclD $=35264 \& \mathrm{mfd}=$ off \&pdoc $=1$

Europia, 2012, Annual Report 2012, European Petroleum Industry Association, Brussels https://www.europia.eu/DocShareNoFrame/Common/GetFile.asp?PortalSource=1362\&D ocID=39335\&mfd=off\&pdoc=1

Eurostat (2013) European Transport Statistics, Main Tables, 2013.

http://epp.eurostat.ec.europa.eu/portal/page/portal/transport/data/main tables

Totten et al (2003): Fuels and Lubricants Handbook: Technology, Properties,

Performance Volume 1; edited by George E. Totten, Steven R. Westbrook, Rajesh J.

Shah

GVR - The Gas Vehicles Review: http://www.ngvjournal.com/magazines/the-gvr/en

GasHighWay (2012), GasHighWay- Route to |Green Transportation, Estonia, February 2012

http://www.gashighway.net/default.asp?sivulD=25922\&component=/modules/bbsView.as p\&recID=22741 

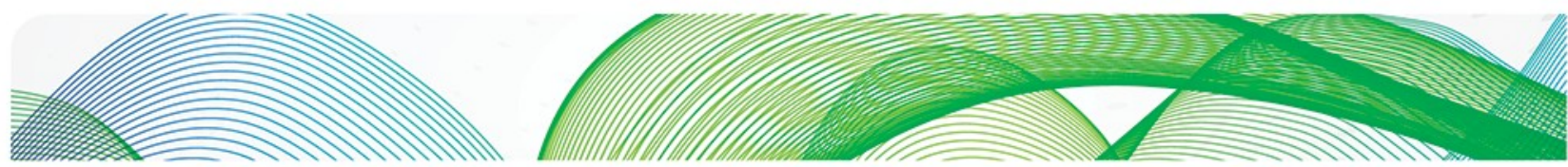

GE Capital, 2011, Company Car Trends, GE Capital Fleet Services, Ofgem, 2012c, Gas Security of Supply Report, Risk and Resilience appendix November 2012 http://www.ofgem.gov.uk/Markets/WhIMkts/monitoring-energy-security/gas-security-ofsupply-report/Documents1/Gas\%20SoS\%20Report\%20-\%20Risk\%20appendix.pdf

GLE (2013), Overcoming barriers in the Small Scale LNG development, GLE Position Paper, Gas LNG Europe, July 2013

http://www.gie.eu.com/index.php/publications/gle/doc download/20951-gle-positionpaper-overcoming-barriers-in-the-small-scale-lng-development

Goodger E. M Transport Fuels Technology, Landfall Press jointly with the (former) Institute of Petroleum, 2000 ISBN 978-0-9520186-2-9, available from Portland Press, Commerce Way, Whitehall Industrial Estate, Colchester, CO2 8

Goodger E. M., Transport fuels today ... and tomorrow, Energy Institute, London

GRSG (2013); LNG Heavy Duty Trucks Case Studies, Informal Document for the 104th meeting of Group of Experts on General Safety United Nations, Geneva 15-19 April 2013

Heffner et al (2005): Heffner, R.R., Kurani, K., Turrentine, T.,. Effects of vehicle image in gasoline-hybrid electric vehicles. Proceedings of 21st Worldwide Battery, Hybrid, and Fuel Cell Electric Vehicle Symposium and Exhibition (EVS-21) [7 December 2009] http://cdm15025.contentdm.oclc.org/cdm/singleitem/collection/p266401coll4/id/3475/rec/7

Huss et al (2013): Huss A, Maas H, Hass, H, 2013, Tank to Wheels report Version 4.0, JEC Joint Research Centre-EUCAR-CONCAWE collaboration, EUR 26027 EN, 2013

ICCT, 2013, European Vehicle Market Statistics, Pocketbook 2013, International Council on Clean Transportation, 28 October, 2013 http://www.theicct.org/european-vehiclemarket-statistics-2013

IEA (2012): World Energy Outlook, November 2012

IEA (2013a): Medium Term Oil Market Outlook,

IEA (2013b): Medium Term Gas Market Outlook,

IEA (2013c): World Energy Outlook, November 2013

IGU (2012): Natural Gas for Vehicles, IGU and UN Economic Commission for Europe Joint report, June 2012

IGU (2013): World LNG report - 2013 edition

IMO (2005) MARPOL; Annex VI Prevention of Air Pollution from Ships, International Maritime Organisation, 2005

ww.imo.org/OurWork/Environment/PollutionPrevention/SpecialAreasUnderMARPOL/Pag es/Default.aspx

IMO (2012): International Shipping Facts and Figures - Information Resources on Trade, Safety, Security, Environment, International Maritime Organisation, 6 March 2012, http://www.imo.org/Publications/Pages/Home.aspx

Kampman et al (2013): Kampman B, Verbeek $R$ et al; Bringing biofuels on the market: Options to increase EU biofuels volumes beyond the current blending limits, TNO Delft, July 2013

Knutsen \& Willen (2013): Daniel Knutsen \& Oscar Willén, 2013, A study of electric vehicle charging patterns and range anxiety, Universtiy of Uppsala, Sweden, June 2013 www.diva-portal.org/smash/get/diva2:626048/FULLTE 

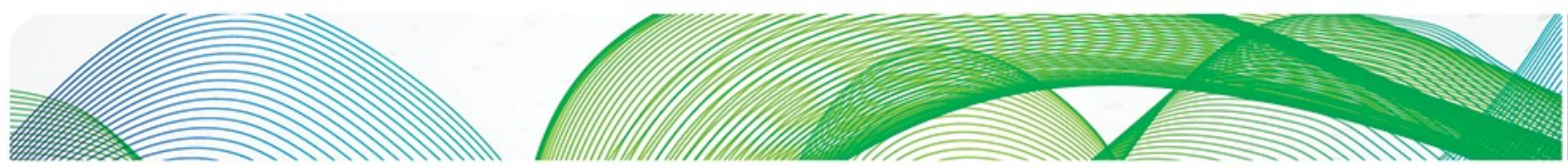

Lane \& Banks (2010): Low Carbon Vehicle Partnership Car Buyer Survey: Improved environmental information for consumers, Research conducted by Ecolane \& Sustain, June 2010

Lloyds Register (2012): LNG-fuelled deep sea shipping, Lloyds Register, August 2012, http://www.Ir.org/Images/LR\%20bunkering\%20study_Final\%20for\%20web_tcm155243482.pdf

Natural Gas Vehicle Conference, Amsterdam (25-26th Nov 2013) Papers available from http://ngvevent.com/eu

Panteia (2013), Contribution to Impact Assessment of measures for reducing emissions of inland navigation, 10 June, 2013

http://ec.europa.eu/transport/modes/inland/studies/inland_waterways_en.htm

PWC (2013); LNG as a fuel - why it's the next big thing for the transport sector, http://www.icisconference.com/uploads/assets/2013 PwC LNG FOR THE TRANSPOR

\section{T SECTOR v1.pdf}

Raucci et al (2013), Raucci C., Smith T., Sabbio N. and Argyros D., Evaluating scenarios for alternative fuels in international Shipping, Paper present at the Low Carbon Shipping conference, London, 2013,

http://www.lowcarbonshipping.co.uk/files/ucl admin/LCS\%202013/Raucci et al.pdf

Ricardo-AEA 2012, Opportunities to overcome the barriers to uptake of low emission technologies for each commercial vehicle duty cycle, A report for the Low Carbon Vehicle Partnership, November 2012,

http://www.lowcvp.org.uk/assets/reports/Opportunities $\% 20$ for $\% 20$ low $\% 20$ emission $\% 20 \mathrm{H}$ GVs\%20-\%20final\%20report\%202012.pdf.

Rules for bunkering of gas-fuelled ships, report by Germanischer-Lloyd, 2012.005, March2013

Ryabtsev (2013); Ryabtsev, Gennadii, Automotive Methane market in Ukraine, Article in Terminal April 2013, Kiev (in Russian). http://oilreview.kiev.ua/2013/04/06/anonsterminala-14-652-ot-8-aprelya-2013-g/

Semolinos (2013); Semolinos p., Olsen G and Giacosa A, LNG as Marine fuel Challenges to be overcome, presentation at LNG 17, Houston April 17, 2013

SMMT (2013), Motor industry facts, 2013, Society of Motor manufacturers and Traders, http://www.smmt.co.uk/2013/03/motor-industry-facts-2013/

USEPA (2008); US Environmental Protection Agency, Global Trade and Fuels

Assessment Future Trends and Effects of Requiring Clean Fuels in the Marine Sector, Report prepared by RTI International, EPA420-R-08-021November 2008

Van Foreest (2012); Van Foreest F, Perspectives for Biogas in Europe, Oxford Institute of Energy Studies, Oxford December 2012

Vyas et al (2002); Vyas A, Saricks C. \& Stodolsky F., The Potential Effect of Future Energy-Efficiency and Emissions-Improving Technologies on Fuel Consumption of Heavy Trucks, Center for Transportation Research, Energy Systems Division, Argonne National Laboratory, Illinois, August 2002. http://www.ipd.anl.gov/anlpubs/2003/03/45815.pdf 

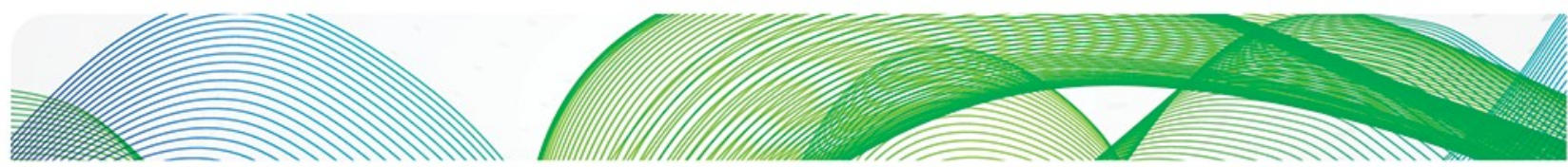

\section{NGV Glossary}

Note some of the terms are used in the gas industry and others in the NGV sector.

- AVERE: The European Association for Battery, Hybrid \& Fuel Cell Electric Vehicles

- BAFA: German border average gas price as reported by the German Federal Office of Economics and Export Control (BAFA)

- Bcm: one billion cubic metres.

- Bcma: one billion cubic metres per annum.

- BEV: Battery electric vehicle

- Biogas: gas produced from the anaerobic digestion of organic matter such as animal manure, sewage, and municipal solid waste.

- Biomass: any organic material which has stored sunlight in the form of chemical energy. As a fuel it may include wood, wood waste, straw, manure, sugarcane, and many other by products from a variety of agricultural processes.

- Biomethane: Biogas which is upgraded to vehicle fuel quality

- BNetzA: German energy regulator (also covers telecommunications, post and rail)

- BTL: Biomass to liquids

- CBG: Compressed biogas (usually mixed with CNG)

- CCGT: Combined cycle gas turbine (power station)

- CEER: The Council of European Energy Regulators - association of Europe's national regulators of electricity and gas at EU and international level for cooperation and to exchange best practice.

- Cl: Compression Ignition

- $\mathrm{CN}$ : Cetane Number

- CNG: compressed natural gas, made by compressing natural gas (which is mainly composed of methane $\left[\mathrm{CH}_{4}\right]$ ), to less than $1 \%$ of the volume it occupies at standard atmospheric pressure. It is a fossil fuel substitute for gasoline (petrol), diesel, or propane/LPG.

- $\mathrm{CO}_{2}$ : Carbon dioxide, the principal greenhouse gas

- CONCAWE: The oil companies' European association for environment, health and safety in refining and distribution

- Conventional Gas: Natural gas produced from an underground reservoir other than shale gas, tight gas or coal bed methane.

- CPT: Clean Power for Transport Package (EU initiative)

- CTL: Coal to liquids

- DECC: UK government Department of Energy and Climate Change

- DENA: Deutsche Energie-Agentur $\mathrm{GmbH}$ (dena) - the German Energy Agency - is the centre of expertise for energy efficiency, renewable energy sources and intelligent energy systems.

- DICl: Direct Injection Compression Ignition

- DISI: Direct Injection Spark Ignition

- Distillation characteristics or volatility : Following extracted from http://www.astm.org/Standards/D86.htm - The distillation (volatility) characteristics of hydrocarbons have an important effect on their safety and performance, especially in the case of fuels and solvents. The boiling range gives information on the composition, the properties, and the behavior of the fuel during storage and use. Volatility is the major determinant of the tendency of a hydrocarbon mixture to produce potentially explosive vapors. The distillation characteristics are critically important for both automotive and aviation gasolines, affecting starting, warm-up, and tendency to vapor lock at high operating temperature or at high altitude, or both. The presence of high boiling point components in these and other fuels can significantly affect the degree of formation of solid combustion deposits.

- DME: Dimethyl ether - a synthetic fuel

- DTI: UK government Department of Trade and Industry - now superseded by DECC

- DWT: Deadweight tonnage 

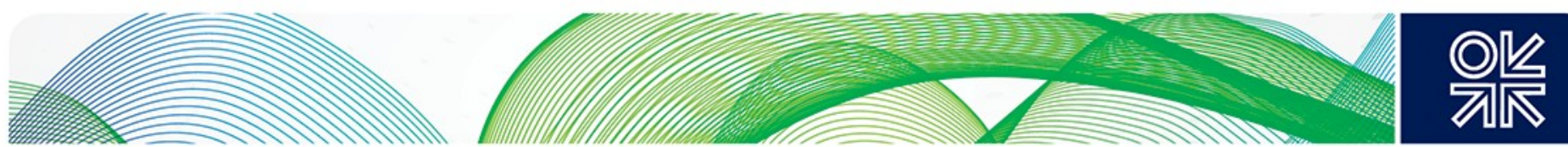

- E10: Gasoline fuel with up to $10 \%$ v/v Ethanol (or 3.7 wt $\%$ oxygen content), according to EN228

- E20: Gasoline fuel with up to $20 \%$ v/v Ethanol or up to 7.4 wt $\%$ oxygen content

- E85: Gasoline fuel with 85\% v/v Ethanol

- EC: European Commission

- EEDI: energy efficiency design index, shipping design requirement introduced by the IMO

- EFET: The European Federation of Energy Traders

- EMSA: European Maritime Safety Agency

- ENTSOG: The European Network of Transmission System Operators for Gas manages and coordinates TSO activities regarding the functioning of the internal market and crossborder trade for gas

- $\quad$ ERGEG: European Regulators Group for Electricity and Gas - now superseded by CEER and ACER

- $\quad$ ETBE: Ethyl Tertiary Butyl Ether produced from bioethanol and isobutylene used and as an octane improver

- $\quad$ EU Emissions Trading System: A cap and trade system under which participating EU Member States allow qualifying $\mathrm{CO}_{2}$ emitting installations to trade $\mathrm{CO}_{2}$ permits. The number of $\mathrm{CO}_{2}$ permits is limited by agreed caps on $\mathrm{CO}_{2}$ emissions at the Member State level.

- EUCAR: European Council for Automotive Research and Development

- EUCAR: The European Council for Automotive R\&D http://www.eucar.be/

- Euro VI: Vehicle fuel standards regulations from the EC aimed at reducing emissions of nitrogen oxides and particulate matters from trucks and buses with effect from January 2013.

- FAME: Fatty Acid Methyl Ester, scientific name for bio-diesel made from vegetable oil and methanol

- FC: Fuel Cell

- FCEV: Fuel Cell driven Electric Vehicle

- FID: Final Investment Decision: usually in the context of a gas project, this is the joint decision on the part of the investment companies and any state entities to proceed with the full development of a project through to commercial operation.

- Fischer-Tropsch: the process named after its original inventors that converts syngas to hydrocarbon chains

- Forward curves: The predetermined delivery prices for gas to be paid at defined dates in the future.

- Gas Forum: The body that represents the view of gas shippers and suppliers active in GB

- GHG: Greenhouse Gas

- GT: Gas transporter

- GTL: Gas to liquids

- GTS: Gas Transportation Services - the Dutch gas TSO

- GVR: The Gas Vehicles Review

- GVW: Gross Vehicle Weight

- GW: Gigawatt, i.e. 1 billion watts

- GwH: Gigawatt hour; a unit of energy equivalent to a Gigawatt of power over the duration of one hour. In this report $1 \mathrm{mcm}=10.83 \mathrm{GwH}$

- HCV: Heavy commercial vehicle - same as an HDV

- HDV: Heavy duty vehicle - typically greater than 16 tonnes GVW

- HEV: Hybrid Electric Vehicle

- HFO: Heavy fuel oil

- HPDI: High-Pressure Direct Injection engine - can run on natural gas or in dual-fuel mode.

- HSE: Health \& Safety Executive (UK)

- HVO: Hydro-treated Vegetable Oil

- ICE: Internal Combustion Engine

- IEA: International Energy Agency

- IFO: Intermediate fuel oil - a marine bunker fuel

- IGEM: Institution of Gas Engineers and Managers (UK)

- IGU: International Gas Union 

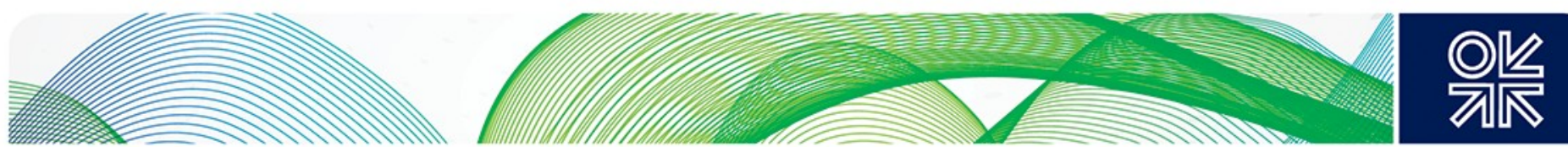

- IMO: International Maritime Organization - the United Nations specialised agency with responsibility for the safety and security of shipping and the prevention of marine pollution by ships.

- IRR: Internal Rate of Return

- ISO: International Organization for Standardization - the world's largest developer of voluntary International Standards

- IWT: Inland waterway transport

- JRC: Joint Research Centre (of the EU Commission

- LHV: Lower Heating Value ('Lower" indicates that the heat of condensation of water is not included)

- LBG: Liquefied biogas (usually mixed with LNG)

- LBM: Liquefied Biomethane

- LDV: Light duty vehicle - cars and small vans

- LNG Terminal: Facility for importing ship borne LNG. Normally the LNG is stored at the terminal before regasification and injection into the transmission system.

- LNG: Liquefied natural gas, natural gas liquefied by cooling to minus 162 degrees Centigrade

- LNGs or LNG storage: (also called LNG Peak Shaver): a gas storage facility which provides high output of natural gas albeit for a short duration. The facility extracts natural gas from the transmission grid, liquefies it and stores it in an insulated vessel. When gas is required to meet peak loads the LNG is regasified and injected into the transmission system. Note this definition does not include storage tanks at LNG regasification terminals

- LPG: Liquid petroleum gas - a generic term for ethane propane and butane mixtures that can exist as liquids at ambient temperatures and modest pressures.

- LSFO: Low sulphur fuel oil

- MARPOL: IMO International Convention for the Prevention of Pollution from Ships, 1973, as modified by the Protocols of 1978 and 1997

- $\quad \mathrm{mcm}$; million cubic metres

- $\mathrm{mcm} /$ day: Million cubic metres per day.

- Methane fuels: common name for CNG and Compressed Biomethane, LNG and Liquified Biomethane, all of them are with methane content over $90 \%$, up to $99 \%$, the methane content depends from the country specific gas quality standards.

- Methane slip: $\mathrm{CH}_{4}$ emissions from the dispensing or incomplete combustion of natural gas in transportation

- MGO: Marine gas oil

- MJ: Megajoule

- Mmbtu: Million British thermal units

- MON: see RON

- MT: Million Tonnes

- MTPA: Million Tonnes per annum

- MTOE: Million Tonnes of oil equivalent

- MWh: A unit of energy equivalent to a Megawatt of power over the duration of one hour.

- $\mathrm{N}_{2}$ : Nitrogen

- $\mathrm{N}_{2} \mathrm{O}$ : Nitrous oxide, a very potent greenhouse gas

- NBP: the UK's National Balancing Point: a virtual point (hub) in the National Transmission System where gas trades are deemed to occur. It is also used as shorthand for the UK spot gas price.

- NDM: Non daily metered gas consumer - normally domestic and small industrial and commercial (I\&C)

- NEDC: New European Drive Cycle

- NG: National Grid plc, the GB TSO

- NGL: Natural gas liquids

- NO: Nitric Oxide

- $\mathrm{N}_{2} \mathrm{O}$ : Nitrous Oxide

- $\mathrm{NO}_{2}$ : Nitrogen dioxide

- $N O_{x:}$ A mixture of various nitrogen oxides (but not nitrous oxide) as emitted by combustion sources

- NPV: Net Present Value

- NTS: The National Transmission System - GB's high pressure gas grid. 

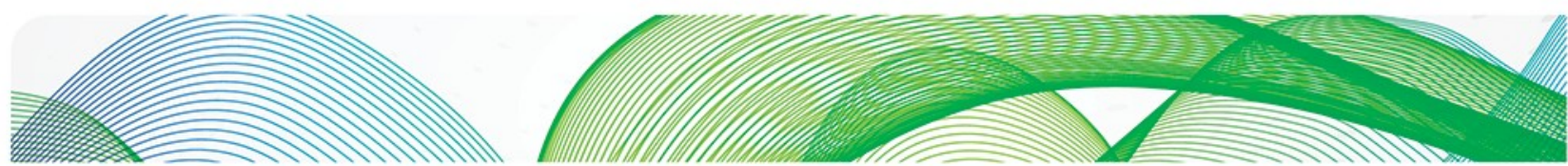

- OEM: original equipment manufacturer. Used in this context to refer to vehicle, vessel and engine manufacturers.

- Ofgem: The Office of Gas and Electricity Markets, the GB gas and electricity regulator

- Oil Indexed Gas Prices: gas prices within long term contracts which are determined by formulae containing rolling averages of crude oil or defined oil product prices.

- PHEV: Plug-In Hybrid Electric Vehicle

- PISI: Port Injection Spark Ignition

- PM: particulate matter - microscopic emissions from diesel engines that have been shown to cause breathing difficulties and to have a carcinogenic effect

- RAV: regulated asset value

- RON: Research Octane Number - a measure of the Octane Number that is meant to be indicative of normal road performance. The Motor Octane Number (MON) is indicative of high speed performance. The octane rating is a measure of how resistant the gasoline is to knocking and higher performance engines require higher octane gasoline.

- SCR: Selective catalytic reduction (SCR) systems work by chemically reducing $\mathrm{NO}$ and $\mathrm{NO}_{2}$ to nitrogen $\left(\mathrm{N}_{2}\right)$

- Shale Gas: natural gas formed in fine-grained shale rock (called gas shales) with low permeability in which gas has been absorbed by clay particles or is held within minute pores and micro fractures.

- SI: Spark Ignition

- SOX: Sulphur oxides

- STS: Ship-to-Ship fuelling system

- TEN-T: The Trans-European Network for Transport Innovation and New Technologies an EC initiative

- Ten Year Statement: Annual planning document issued by NG

- Therm: Imperial unit of energy used in GB gas pricing - 1 therm is equal to $29.3071 \mathrm{kWh}$.

- Tight Gas: natural gas formed in sandstone or carbonate (called tight gas sands) with low permeability which prevents the gas from flowing naturally.

- TPA: Third Party Access - in the context of storage there is regulated - rTPA - or negotiated third party access - nTPA.

- TPS: Terminal-to-Ship via Pipeline fuelling system

- TSO: Transmission System Operator

- TTF: Title Transfer Facility - the Dutch trading hub

- TTW: Tank-To-Wheels, description of the burning of a fuel in a vehicle

- TTS: Truck-to-Ship fuelling system

- TWh: A unit of energy equivalent to a Terawatt of power over the duration of one hour.

- UKCS: The UK Continental Shelf

- Vehicle Parc: number of vehicles available for use at any one time

- WLTP: Worldwide harmonized Light duty Test Procedure - a chassis dynamometer test cycle for the determination of emissions and fuel consumption from light-duty vehicles. The test was developed by the UN ECE GRPE (Working Party on Pollution and Energy) group

- WTT Well-To-Tank: the cascade of steps required to produce and distribute a fuel (starting from the primary energy resource), including vehicle refueling

- WTW Well-To-Wheels: the integration of all steps required to produce and distribute a fuel (starting from the primary energy resource) and use it in a vehicle

- $\quad x E V$ x-Electrified Vehicle, collective name for all electrified configurations 